Projektbericht

Research Report

\title{
Evaluation of the Austrian National Reform Programme Effects on Growth and Employment
}

Johannes Berger Bernhard Felderer Ines Fortin

Michaela Gstrein Niki Graf Helmut Hofer Hermann Kuschej

Andrea Leitner

Liliana Mateeva lain Paterson Ulrich Schuh Wolfgang Schwarzbauer Edith Skriner Mario Steiner Ludwig Strohner Klaus Weyerstraß Angela Wroblewski 

Projektbericht

Research Report

\title{
Evaluation of the Austrian National Reform Programme Effects on Growth and Employment
}

\author{
Johannes Berger \\ Bernhard Felderer \\ Ines Fortin \\ Michaela Gstrein \\ Niki Graf \\ Helmut Hofer \\ Hermann Kuschej \\ Andrea Leitner \\ Liliana Mateeva \\ lain Paterson \\ Ulrich Schuh \\ Wolfgang Schwarzbauer \\ Edith Skriner \\ Mario Steiner \\ Ludwig Strohner \\ Klaus Weyerstraß \\ Angela Wroblewski
}

Final report Study on behalf of the Austrian Federal Ministry of Economics and Labour (BMWA)

Dezember 2006

Institut für Höhere Studien (IHS), Wien Institute for Advanced Studies, Vienna 


\section{Contact:}

Bernhard Felderer

Im: +43/1/599 91-125

email: felderer@ihs.ac.at

Ulrich Schuh

Im: +43/1/599 91-148

email: schuh@ihs.ac.at

\section{Comment}

This report presents a first evaluation of the growth and employment effects of the Austrian National Reform Programme 2005 - 2008 (NRP) that summarizes Austrian attempts to promote EU Lisbon targets. Undertaken in autumn 2006 - only a short time after its implementation - it can only be seen as a first assessment of potential effects. The evaluation focuses on the potential impact of the NRP on growth and employment. Quantitative and qualitative effects are deducted from existing national and international evidence. 


\section{Contents}

Kurzfassung 1

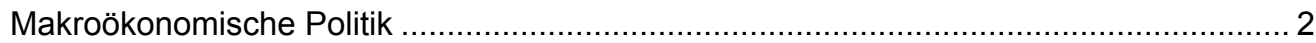

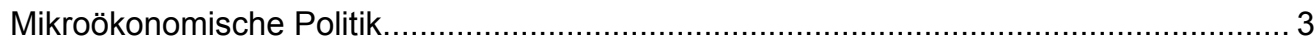

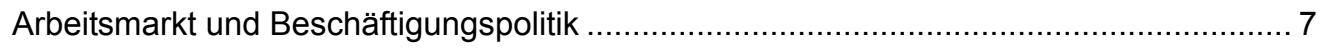

Executive Summary 11

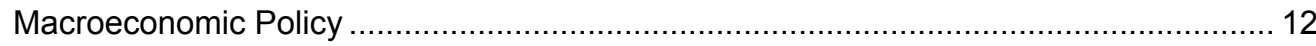

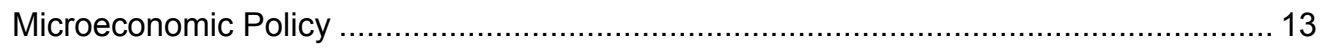

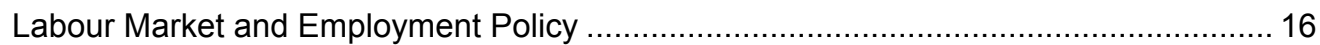

$1 \quad$ Background and Evaluation Framework 19

2 Macroeconomic Policy 27

$3 \quad$ Microeconomic Policy 37

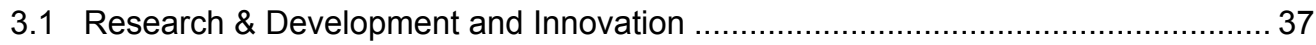

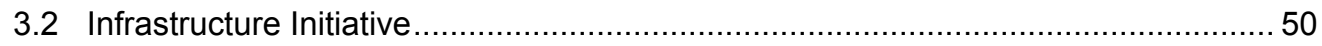

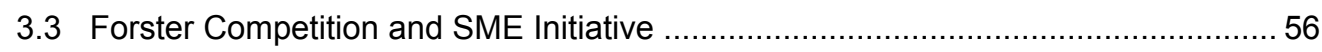

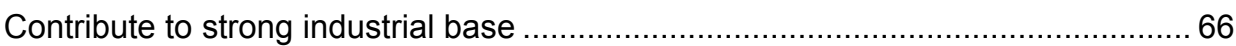

Extend and deepen the internal market for financial services .............................. 72

Safeguard economic position and encourage SMEs .......................................... 76

Better Regulation, Entrepreneurial Culture and SME Support................................. 83

3.4 Environmental technologies and efficient resource management.......................... 92

$4 \quad$ Employment Policy 105

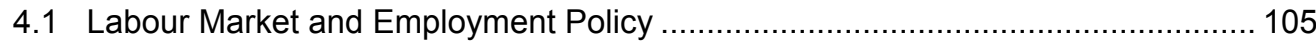

Labour Market and Employment Policy - an overall assessment ....................... 108

Labour Market and Employment Policies - analysis according to target

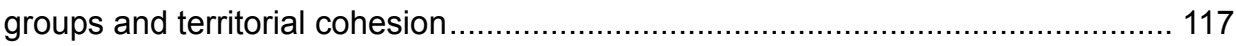

Women

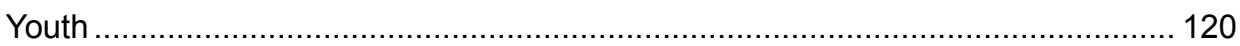

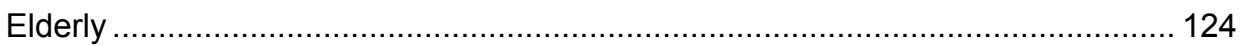

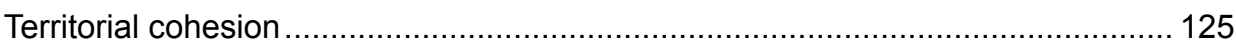

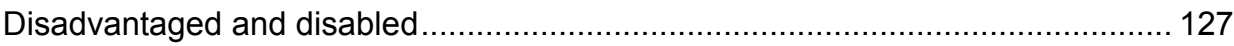

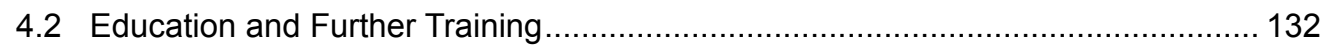

ANNEX 141

ANNEX 1: More information on exports of goods, services and Austrian FDI .............. 142

ANNEX 2: TAXLAB - Dynamic Computable General Equilibrium Model for Austria ...... 146

Bibliography 



\section{Kurzfassung}

Die vorliegende Evaluierung des Österreichischen Nationalen Reformprogramms (NRP) durch das Institut für Höhere Studien wurde im Herbst 2006 - zeitgleich mit der Übermittlung des ersten Umsetzungsberichts an die Europäische Kommission - durchgeführt. Sie bietet eine erste vollständige Analyse der erwarteten Auswirkungen aller NRP Initiativen und deren Wechselwirkungen innerhalb der Österreichischen Volkswirtschaft.

Unter Bedachtnahme auf den gegenwärtigen Stand der Implementierung des NRP hat der Bericht

- die zentralen Politikbereiche des Reformprogramms identifiziert,

- abgeschätzt inwieweit die beschlossenen oder geplanten Maßnahmen zur Erreichung der Ziele der Lissabonstrategie beitragen können,

- erste grobe Schätzungen der Effekte der verschiedenen Maßnahmen des Österreichischen NRP erstellt, die auf das inländische Wachstum und die Beschäftigung ausgehen könnten.

Der Österreichische NRP umfasst mehr als hundert unterschiedliche Maßnahmen. Er spiegelt jene sieben zentralen Politikbereiche wider, die von der Österreichischen Bundesregierung identifiziert wurden.

In allen relevanten Politikbereichen behauptet sich Österreich vergleichsweise gut. Bei der Mehrheit der vorliegenden Indikatoren befindet sich Österreich in der Spitzengruppe unter den Mitgliedstaaten der Europäischen Union. Ausgehend von dieser vergleichsweise günstigen Ausgangsposition konzentriert sich der Österreichische NRP auf Initiativen, die das Wachstumspotenzial der Österreichischen Wirtschaft stärken, und auf Maßnahmen, die auf die einzelnen identifizierten landesspezifischen Politikbereiche fokussiert sind.

Aufbauend auf von nationalen und internationalen Studien abgeleiteter Evidenz und Modellsimulationsrechnungen wurden grobe Abschätzungen der Effekte der Maßnahmen des NRP erstellt. Dementsprechend wurde geschätzt, dass der Österreichische NRP die langfristige Wachstumsrate der Österreichischen Volkswirtschaft durch eine Anhebung der Investitionen in Forschung und Entwicklung (F\&E), eine intensivere Nutzung von Informations- und Kommunikationstechnologien (IKT) und strukturelle Verbesserungen im österreichischen Finanzsektor um 0.10 bis 0.15 Prozentpunkte erhöhen könnte. Zusätzlich könnten (1) Investitionen in Infrastruktur, (2) Verringerungen im Verwaltungsaufwand von Unternehmungen und (3) aktive Arbeitsmarktpolitik zu einer nachhaltigen Erhöhung des Niveaus des realen Bruttoinlandsprodukts um nahezu $3 \%$ führen. Die Verringerung der 
Steuer- und Abgabenquote um einen Prozentpunkt könnte einen Anstieg des realen Bruttoinlandsprodukts um $2 \%$ bewirken. Für einige wichtige Politikbereiche, wie etwa Wettbewerbspolitik oder die Förderung von Kleinen- und Mittleren Unternehmungen (KMU), war es nicht möglich quantifizierbare Ergebnisse herzuleiten. Die ermittelten Ergebnisse sollten allerdings lediglich als eine erste Orientierung für die möglichen Größenordnungen der Wirkungen des NRP angesehen werden. Es wird darauf hingewiesen, dass die Wirkungen mit einer erheblichen Verzögerung eintreten dürften und dass in einigen Politikbereichen die beabsichtigten Maßnahmen erst in einigen Jahren vollständig implementiert sein werden. Tatsächlich wird eine effektive Abschätzung der Wirkungen des NRP erst nach geraumer Zeit möglich sein, wenn entsprechendes Datenmaterial zur Verfügung stehen wird.

\section{Makroökonomische Politik}

\section{Politikbereich 1: Makroökonomische Politik - Nachhaltigkeit der öffentlichen Finanzen}

In einer Gesamtbetrachtung des Abschnitts zur makroökonomischen Politik innerhalb des NRP zeigt sich, dass die makroökonomische Strategie kohärent ist und, dass Steuersenkungen Beschäftigung und Wirtschaftswachstum unterstützen. Die österreichische Strategie ruht auf drei Säulen: einem ausgeglichenen Budgetsaldo über den Konjunkturzyklus, der Verringerung der Steuer- und Abgabenquote unter $40 \%$ des BIP bis 2010 sowie der Umschichtung der Ausgabenstruktur zu Gunsten von F\&E, Innovation, Bildung und Infrastruktur. Diese Strategie erhöht das Wachstumspotenzial der österreichischen Volkswirtschaft.

Gegenwärtig stellt sich die Entwicklung der österreichischen Volkswirtschaft vorteilhaft dar. Im Jahr 2005 lag das Bruttoinlandsprodukt in Kaufkraftstandards (KKS) um $22.5 \%$ über dem Durchschnitt der EU-25. Dieser Wert entspricht Platz 5 hinter Luxemburg, Irland, Dänemark und den Niederlanden. Nach drei Jahren mäßigen Wirtschaftswachstums übertraf der Anstieg des realen BIP seit 2004 den EU-Durchschnitt. Für das Jahr 2006 wird ein positiver Wachstumsvorsprung von einem halben Prozentpunkt prognostiziert.

In den vergangenen Jahren wurde ein merkbarer Fortschritt im Bereich der Nachhaltigkeit der öffentlichen Finanzen erzielt. Die jüngsten Reformen des Pensions- und Gesundheitssystems haben Österreich in eine günstige Position gebracht. Die vorliegenden Langfristprojektionen der Europäischen Kommission und des Wirtschaftspolitischen Komitees belegen, dass Österreich derzeit zu der Ländergruppe mit einer niedrigen Gefährdung der Nachhaltigkeit der öffentlichen Finanzen zählt.

Der Österreichische NRP sieht vor, die Steuer- und Abgabenquote bis zum Jahr 2010 unter $40 \%$ des BIP abzusenken und gleichzeitig die Ausgabenstruktur zu Gunsten wachstumsfördernder Ausgaben wie F\&E, Bildung oder Infrastruktur zu verändern. 
Eine Simulationsrechnung mit Hilfe des dynamischen Gleichgewichtsmodells des IHS (TAXLAB) ergibt, dass die Verringerung der Steuer- und Abgabenquote um einen Prozentpunkt des BIP eine nachhaltige Erhöhung des realen Bruttoinlandsprodukts um beinahe $2 \%$ nach sich zieht. Durch die Absenkung der Steuersätze in der Einkommensteuer würden 40.000 zusätzliche Arbeitsplätze geschaffen.

Diese Ergebnisse unterstreichen das Potenzial weiterer Steuerreformen in Österreich. Gleichzeitig belegen sie, welche impliziten Kosten die Finanzierung von Ausgaben über die Erhöhung der Abgaben hervorruft. Obwohl Steuersenkungen wichtige Anreize für Arbeitsaufnahme und Investitionstätigkeit setzen, sollten sie nicht über eine Ausweitung der Staatsverschuldung ermöglicht werden, weil steigende Budgetdefizite wiederum durch zukünftige Einsparungen oder Steuererhöhungen ausgeglichen werden müssen. Da der öffentliche Haushaltssaldo gegenwärtig ein Defizit von mehr als einem Prozent des BIP aufweist, werden spürbare Steuersenkungen in der nahen Zukunft als unrealistisch angesehen.

\section{Mikroökonomische Politik}

\section{Politikbereich 2: Forschung und Entwicklung, Innovation}

Die endogene Wachstumstheorie besagt, dass F\&E und Innovation (ebenso wie Humankapitalakkumulation) zur Bildung von Wissen führen, welches wiederum technischen Fortschritt bewirkt und dadurch eine wesentliche Triebfeder des Wirtschaftswachstums darstellen. Empirische Untersuchungen bestätigen diese Hypothese und weisen auf signifikante positive Wirkungen von F\&E und Innovationen auf Wachstum hin. Im Rahmen der einschlägigen Bemühungen hat sich insbesondere die privatwirtschaftlich organisierte $F \& E$ und Innovationstätigkeit als die treibende Kraft des technischen Fortschritts erwiesen; dies ist zumindest in einer kurz- bis mittelfristigen Perspektive der Fall.

Eine Kombination von direkten und indirekt wirksamen Maßnahmen unterstützt die Erreichung der Zielvorgaben im Bereich von F\&E und Innovation. Staatliche Aktivitäten zielen darauf ab, privatwirtschaftliche F\&E-Initiativen zu unterstützen, zusätzliche private Investitionen auszulösen sowie ausländische Investitionen anzuziehen (Headquarter Strategie) und beruhen auf der Reorganisation der Fördermittelvergabe und der effizienten Bereitstellung von Finanzierungsmöglichkeiten und Fördermitteln für internationale Vernetzung sowie der Förderung von jungen Akademikern und strategischer Forschung.

Das IHS schätzt, - basierend auf Ergebnissen der einschlägigen Literatur und der Annahme eines ansteigenden Anteils der privaten F\&E- und Innovationstätigkeit - dass die gemeinsamen Anstrengungen im Bereich von F\&E und Innovation einen nachhaltigen Wachstumsanstieg um 0.1 Prozentpunkte des BIP bewirken werden. Zu beachten ist allerdings, dass, entsprechend den Erfahrungen aus der einschlägigen Literatur, die Effekte nur mit erheblicher Verzögerung wirksam werden. Empirische Studien lassen erwarten, dass das 


\section{$4-$ Evaluation of the NRP/I H S}

Wirtschaftswachstum mit einer Verspätung von sieben bis zwanzig Jahren durch die Investitionstätigkeit erhöht wird.

Es wird erwartet, dass die Beschäftigung lediglich durch Zweitrundeneffekte der F\&E und Innovationstätigkeit beeinflusst wird, weil derartige Aktivitäten primär die Produktivität der Beschäftigten und die Effizienz der Volkswirtschaft erhöhen.

Es wird allerdings darauf hingewiesen, dass die empirischen Befunde zur Wirkung von F\&E und Innovation auf Wirtschaftswachstum und Beschäftigung eine erhebliche Streuung aufweisen. Die hier angeführte Schätzung sollte als eine vorsichtige Annäherung an potenzielle Effekte angesehen werden.

\section{Politikbereich 3: Infrastruktur (inklusive Breitband)}

Die endogenen Wachstumstheorien besagen, dass Infrastruktur eine Triebfeder des Wirtschaftswachstums darstellt. Die Verbesserung der (Verkehrs-)Infrastruktur verringert die Kosten für die privaten Unternehmungen und führt zu einem effizienteren Einsatz der vorhandenen Ressourcen. Quantitative Effekte von Infrastrukturinvestitionen sind empirisch ausgiebig untersucht worden. Österreich hat inzwischen eine sehr gute Ausstattung mit Infrastruktur - allerdings gibt der Beitritt von zehn neuen Staaten zur Europäischen Union Anlass für weitere Investitionen. Österreich beabsichtigt in den nächsten Jahren 45,1 Mrd. € in die Verkehrsinfrastruktur zu investieren (davon 29,9 Mrd. $€$ in den Schienen-, 15 Mrd. $€$ in den Straßen- und 0,2 Mrd. € in den Wasserverkehr).

Aufgrund der Verfügbarkeit von Datenmaterial beschränkt sich die Abschätzung der Effekte auf die geplanten Investitionen in die Verkehrsinfrastruktur. Die Ergebnisse lassen eine langfristig wirksame Erhöhung des realen Bruttoinlandsprodukts um 1,5 Prozentpunkte erwarten.

\section{Politikbereich 4: Stärkung des Wettbewerbs und KMU Offensive}

Ein hohes Maß an Investitionen in IKT hat zum Wachstumsschub der Produktivität in den Vereinigten Staaten seit 1995 beigetragen. Investitionen in und die effektive Nutzung von IKT stellen einen integralen Bestandteil der Lissabon Strategie dar. Der Einfluss von IKT auf Produktivität wird über drei Kanäle wirksam: durch die Erhöhung des Kapitalstocks („Capital Deepening“), durch die Erhöhung der Faktorproduktivität - hervorgerufen durch das Wachstum der hochtechnologischen IKT-Sektoren - und schließlich durch Spillovers in andere Sektoren. Die Maßnahmen des Österreichischen NRP in diesem Bereich entsprechen den Vorgaben der Lissabon Strategie und werden als angemessen eingeschätzt. Es stellt sich allerdings als schwierig dar, die Größenordnung der Effekte der gesetzten Initiativen einzuschätzen, weil zahlreiche Studien gezeigt haben, dass IKT in Wechselwirkung mit anderen relevanten ökonomischen Einflussgrößen steht. Die Breitbandinitiative wird gemeinsam mit der erfolgreichen Umsetzung der geplanten Maßnahmen im Bereich e-government voraus- 
sichtlich die österreichische Faktorproduktivität langfristig erhöhen. Der damit verbundene Anstieg im Wirtschaftswachstum sollte auch die Arbeitsnachfrage positiv beeinflussen. Letztere Wirkung ist allerdings nicht empirisch abgesichert, weil ein Anstieg der Produktivität nicht notwendigerweise mit einem Anstieg der Arbeitsnachfrage verbunden ist - je nachdem ob der Produktivitätsanstieg von Rationalisierungen begleitet ist oder nicht.

In Hinblick auf die Marktkapitalisierung und die Verfügbarkeit von inländischem Kreditvolumen für den privaten Sektor befindet sich Österreich unter dem Durchschnitt der EU-15 Mitgliedstaaten; demgegenüber ordnet sich die Performanz der Österreichischen Börse im obersten Drittel der EU-15 ein. Initiativen im Bereich der Finanzmärkte sind in die umfassenden Strategien auf Ebene der Europäischen Union eingebettet; bisher erfolgte die Umsetzung der Maßnahmen zeitgerecht. Die im NRP angeführten Maßnahmen, insbesondere FSAP und SEPA, stellen einen integralen Teil der EU-weiten Programme zur Integration der Finanzmärkte dar. Da die Effekte der im Jahr 2006 beschlossenen Maßnahmen erst langfristig wirksam werden (und wahrscheinlich auch nicht unmittelbar von den im Zeitraum 2005 bis 2007 gesetzten Maßnahmenpaketen getrennt werden können), sind nur sehr grobe Abschätzungen basierend auf der internationalen Literatur der oben angeführten Maßnahmen möglich. Vorausgesetzt, dass alle Maßnahmen des FSAP und SEPA Programms erfolgreich umgesetzt werden, ist davon auszugehen, dass die langfristige Wachstumsrate des Potenzialoutputs marginal erhöht wird.

Die schädlichen Konsequenzen von Kartellen sind sowohl theoretisch als auch empirisch ausgiebig dokumentiert. In diesem Bereich sind die gegenwärtigen Initiativen darauf ausgerichtet das Österreichische Gesetzeswerk an die Richtlinien der Europäischen Union anzupassen und die Verwaltungsabläufe zu vereinfachen. Veränderungen im Wettbewerbsgesetz werden voraussichtlich keine unmittelbaren Vorteile im Bereich von Beschäftigung und Wachstum nach sich ziehen. Es ist allerdings zu erwarten, dass Verbesserungen im Wettbewerbsrecht in der Folge positive Wirkungen entfalten werden.

Die erhöhte Öffnung der Volkswirtschaft hat einen positiven Einfluss auf das wirtschaftliche Wachstum und den internationalen Handel und hat statistisch signifikante positive Konsequenzen für die Produktivität. Es werden dadurch auch positive Skaleneffekte ausgelöst. Der Außenhandelssektor verzeichnete eine ausgezeichnete Entwicklung in den vergangenen Jahren: im Durchschnitt sind die Exporte um 3.1\% real gewachsen (im Vergleich dazu stieg das BIP um $2.1 \%$ ). Im laufenden und kommenden Jahr wird der Außenhandel eine tragende Säule des Wirtschaftswachstums Österreichs darstellen. Das Institut für Höhere Studien (IHS) erwartet, dass die Exporte im Jahresdurchschnitt 3,3 Prozentpunkte zur BIP-Wachstumsrate beitragen werden. Aufgrund der Bemühungen im Rahmen der Initiative "go-international“, die österreichische Unternehmungen dabei unterstützt ihre Wettbewerbsfähigkeit zu verbessern, dürften die Exporte von Dienstleistungen - gegenwärtig quantitativ noch relativ gering - an Bedeutung gewinnen. 
Aufgrund der Wirtschaftsstruktur der Europäischen Union sind gezielte Maßnahmen zur Unterstützung von KMUs unerlässlich. Themen in diesem Zusammenhang stellen die Finanzierungskosten, die Besteuerung von KMUs und die Verringerung von administrativen Hürden dar. Wichtige österreichische Maßnahmen stellen die KMU Initiative 2006, laufende Förderprogramme der aws und die Implementierung des Standard Cost Modells zur Verringerung der Verwaltungskosten dar. Eine Modellrechnung für den möglichen Effekt von verringerten Verwaltungskosten für Unternehmungen lässt einen Zuwachs des realen BIP um einen 3/4 Prozentpunkt und 12.000 zusätzliche Arbeitsplätze erwarten, wenn die Zielvorgaben des NRP erreicht werden. Die Anstrengungen Österreichs lassen positive Auswirkungen im Einklang mit der Strategie der Europäischen Union erwarten. Die zielgerichteten Aktivitäten entsprechen den wahrgenommenen Problemlagen der österreichischen Unternehmungen und können folglich als passend angesehen werden.

\section{Politikbereich 5: Umwelttechnologien and effiziente Nutzung der Ressourcen}

Da die Lissabon-Strategie auf eine nachhaltige Anhebung des Wachstumspotenzials der Mitgliedstaaten abzielt, muss den mittel- bis langfristigen Umweltauswirkungen des Wirtschaftswachstums besondere Bedeutung beigemessen werden. Nach den Aussagen der endogenen Wachstumstheorie ist Wirtschaftswachstum dann nachhaltig, wenn es durch neue Technologien gelingt, das Verhältnis der Umweltverschmutzung pro erzeugter Outputeinheit zu verringern. Vorrangig geht es bei den Initiativen im Bereich der Umweltpolitik also darum das Wirtschaftwachstum mit den Umweltbedingungen vereinbar zu machen.

Die Entwicklung, der Einsatz und die Verwendung von Umwelttechnologien kann allerdings auch positive Auswirkungen auf Wachstum und Beschäftigung zeitigen. Die endogene Wachstumstheorie und Untersuchungen der Umweltindustrie besagen, dass Investitionen in Umwelttechnologien eine hohe Wertschöpfung induzieren, Arbeitsplätze schaffen, Exporte anregen und die Substitution von importierten fossilen Energieträgern durch inländische erneuerbare Energie ermöglichen.

Umweltindustrien, die auch moderne „saubere Technologien“ umfassen, stellen einen Wachstumsbereich in Österreich dar und gewähren den österreichischen Unternehmungen gute Exportchancen auf den internationalen Märkten. Die Europäische Kommission hat die kohärente österreichische Strategie begrüßt, die Innovation erhöht und den Einsatz von Umwelttechnologien vorantreibt.

Die europäische Vergleichsstudie ECOTEC bestätigt die Ansicht, dass Öko-Industrien sowohl direkt als auch indirekt Beschäftigung schaffen. Die Auswirkungen auf Beschäftigung und Wertschöpfung von Investitionen in erneuerbare Energie und Ökostrom-Einrichtungen können positiv oder negativ ausfallen, wobei sowohl direkte als auch indirekte wie auch kurzund langfristige Effekte berücksichtigt werden. 
Der Anteil von erneuerbaren Energieträgern an der gesamten inländischen Energienachfrage in Österreich hat von 1990 bis 2003 zugenommen. Im Jahr 2003 nahm Österreich den vierten Platz innerhalb der EU-25 mit einem Anteil von $20 \%$ ein. Im Jahr 2005 betrug der Anteil 22,12\%. Im Jahr 2004 war Österreich aufgrund des Einsatzes von energiesparenden Umwelttechnologien der Mitgliedstaat mit der zweitniedrigsten Energieintensität innerhalb der EU-15.

Um den Nettoeffekt der Investitionen und des Einsatzes von neuen Ökostromanlagen zu erhalten, müssen die positiven Auswirkungen auf Beschäftigung und Wertschöpfung den negativen indirekten Effekten aus der Verringerung des verfügbaren Einkommens gegenübergestellt werden. Während die positiven Effekte unmittelbar auftreten, werden die negativen indirekten Effekte erst langfristig schlagend.

\section{Arbeitsmarkt und Beschäftigungspolitik}

\section{Politikbereich 6: Arbeitsmarkt und Beschäftigungspolitik}

Insgesamt stellt sich die österreichische Arbeitsmarktlage - gemessen an den allgemeinen Entwicklungen von Arbeitslosigkeit oder Beschäftigungswachstum - günstig dar. Darüber hinaus ist die Langzeitarbeitslosigkeit im EU-Vergleich weiterhin relativ niedrig.

Das Beschäftigungsausmaß ist insgesamt und auch für Frauen in allen Altersgruppen sehr hoch. Das Beschäftigungspotenzial älterer Arbeitnehmer wird allerdings nicht ausgeschöpft, was sich an anhaltend niedrigen Partizipationsquoten ablesen läßt. Trotz beträchtlicher Reformanstrengungen in den vergangenen Jahren ist es der Politik nicht gelungen das effektive Pensionsantrittsalter in Österreich merkbar zu erhöhen.

In Hinblick auf geschlechtsspezifische Unterschiede ist die Lage im Bereich der weiblichen Teilnahme am Arbeitsmarkt günstig. Die Beschäftigungs- und Partizipationsquoten von Frauen befinden sich über dem EU-Durchschnitt, die Arbeitslosenquote liegt knapp darunter. Dieser Befund trifft aber nicht für Frauen aller Altersgruppen zu. Grundsätzlich sind ältere Frauen und solche mit niedrigerem Ausbildungsstand weniger gut in den Arbeitsmarkt integriert. Der Gender Gap im Bereich der Beschäftigung ist weniger stark in der Grundgesamtheit ausgeprägt; dem steht allerdings ein sehr hoher geschlechtsspezifischer Unterschied in der Entlohnung gegenüber, der insbesondere im privaten Sektor und bei älteren Arbeitnehmern zu erkennen ist.

Besondere Aufmerksamkeit sollte der Entwicklung der Jugendarbeitslosigkeit gewidmet werden. Obwohl die Jugendarbeitslosigkeit immer noch unter den Durchschnittswerten der EU-25 und EU-15 liegt, ist sie in den vergangenen Jahren doch dramatisch angestiegen. Ausgehend von einer Jugendarbeitslosenquote von $2.8 \%$ im Jahr 2000, ist diese für die 
Altersgruppe der 15-25 jährigen auf 6.1\% im Jahr 2005 angestiegen. Diese Entwicklung trifft sowohl für Frauen als auch Männer zu.

In Hinblick auf die regionale Arbeitsmarktentwicklung ist eine weitgehend einheitliche Entwicklung zu konstatieren. Es besteht ein hohes Ausmaß an Ähnlichkeit was die Beschäftigungs- und Arbeitslosenquoten auf regionaler Ebene betrifft.

In den vergangenen Jahren hat die Österreichische Bundesregierung beträchtliche Anstrengungen - entlang der Vorgaben der Beschäftigungspolitischen Leitlinien - unternommen, um die Funktionsweise der Arbeitsmärkte zu verbessern und, um die aktiven Personen bei der Suche nach geeigneten Arbeitsplätzen zu unterstützen. Zusätzlich zu den bereits laufenden Programmen wurden weitere Maßnahmen im Zusammenhang mit dem NRP eingeführt. Die Zusammensetzung der im NRP angeführten Maßnahmen spiegelt die identifizierten Problembereich des österreichischen Arbeitsmarkts adäquat wieder.

Ausgehend von bestehenden Evaluierungen von vergleichbaren Arbeitsmarktinitiativen auf nationaler und internationaler Ebene können die mögliche Effekte des NRP grob abgeschätzt werden. Basierend auf den verfügbaren Angaben über die zusätzlichen Maßnahmenteilnehmer in den verschiedenen Arten von Arbeitsmarktprogrammen könnten etwa 30.000 zusätzliche Arbeitsplätze geschaffen werden. Dies würde einen Anstieg des realen BIP um etwa einen halben Prozentpunkt hervorrufen. Diesbezüglich wird darauf hingewiesen, dass diese Werte eine sehr grobe Abschätzung darstellen und als eine Obergrenze für die möglichen Wirkungen angesehen werden sollten.

\section{Politikbereich 7: Aus- und Weiterbildung}

Hinsichtlich der wesentlichen Indikatoren, die für Aus- und Weiterbildung herangezogen werden, weist Österreich eine gute Position im EU-Vergleich auf. Die Mehrzahl der Zielvorgaben von Lissabon für 2010 werden von Österreich bereits erfüllt.

Gemäß der vorliegenden Indikatoren, sind sowohl beim Ausmaß der Ausgaben, als auch bei der Teilnahme an Aus- und Weiterbildung keine Problembereiche zu identifizieren. Es scheint, dass Maßnahmen in kleinerem Ausmaß ausreichen sollten, um die erforderliche Teilnahme an Weiterbildungsmaßnahmen zur Erreichung der Zielvorgaben für $2010 \mathrm{zu}$ erzielen. Wenn berücksichtigt wird, dass die verwendeten Indikatoren des zugrundeliegenden Berichts auf Zahlen des Jahres 1999 beruhen und in der Zwischenzeit bestimmte Maßnahmen beschlossen wurden, so ist es denkbar, dass keine weiteren Aktivitäten erforderlich sind, wenn der alleinige Zweck die Erreichung der Zielvorgaben für 2010 darstellt.

Allerdings gibt es einige Mitgliedstaaten der Europäischen Union, die in diesem Bereich bessere Ergebnisse vorweisen als Österreich. An diesen Ländern sollte sich Österreich jedenfalls orientieren. In Polen etwa beträgt der Anteil der vorzeitigen Schulabbrecher ledig- 
lich $5.5 \%$. Sollte Österreich diese Benchmark bis 2010 erreichen wollen, so wären zusätzliche Anstrengungen erforderlich.

Maßnahmen im Bereich der Aus- und Weiterbildung tragen jedenfalls zu Beschäftigung und Wirtschaftswachstum bei, dies allerdings hauptsächlich über indirekte Wirkungskanäle und in einer mittelfristigen Perspektive. Größeres Augenmerk sollte auf direkte Qualifizierungsmaßnahmen, insbesondere im Bereich der Weiterbildung, gelegt werden. Im Bereich der mittleren Ausbildungsstufen ist davon auszugehen, dass die gesetzten Maßnahmen die Beschäftigungschancen der betroffenen Schüler deutlich verbessern und damit einen direkten Beschäftigungseffekt auslösen sollten. 



\section{Executive Summary}

The present evaluation of the Austrian National Reform Programme (NRP) by the Institute of Advanced Studies was undertaken in autumn 2006 - at the same time as the first annual progress report to the Commission. It offers a first complete analysis of the expected growth and employment effects of all NRP actions and their interactions within the Austrian economy.

Given the current stage of the implementation of the NRP this report has

- identified the main policy areas where the Austrian reform programme is concentrated,

- assessed the extent to which the enacted or planned measures may contribute to the achievement of the goals of the Lisbon Strategy,

- produced rough estimates of the effects the different measures of the Austrian NRP could have on domestic growth and employment.

The Austrian NRP comprises over one hundred separate measures. It mirrors the seven key policy areas that have been identified by the Austrian government.

Austria currently performs relatively well in all relevant policy fields. In comparison to other Member States of the European Union, Austria ranks in the top group according to the majority of the available indicators. Given this relatively comfortable starting position, the Austrian NRP concentrates on initiatives that strengthen the growth potential of the Austrian economy and on policies that focus on individual identified country- specific policy areas.

Based on existing evidence deducted from national and international studies and model simulations, we have generated rough estimates of the impact the measures of the Austrian NRP will produce. Accordingly, the Austrian NRP could increase the long-term growth rate of the Austrian economy by 0.1 to 0.15 percentage points via higher investment into Research and Development (R\&D), a more intensive use of Information and Communication Technologies (ICT), and structural improvements of the Austrian financial sector. In addition to an (1) investment into infrastructure, (2) reductions of the administrative burden of enterprises and (3) active labour market policies may result in a sustainable increase of the level of real GDP by almost $3 \%$. A reduction of the tax burden by 1 percentage point could result in an increase of GDP by $2 \%$. For some important policy areas, like for example competition policies and support of small and medium sized enterprises (SME), it has not been possible to generate quantifiable estimates. The results should, however, be seen only as a first orientation for the potential order of magnitude of the impact of the Austrian NRP. It 
should be noted, that the effects will become manifest only with a considerable time lag and that in some policy areas it will take several years until these measures may be implemented. An effective assessment of the impact of the NRP measures will be possible only after some time, when empirical evidence is available.

\section{Macroeconomic Policy}

\section{Key Policy Area 1: Macroeconomic Policy - Sustainable Public Finances}

An overall assessment of the macroeconomic policy section in the NRP shows that the macroeconomic policy is coherent and that tax cuts support employment and GDP growth. The Austrian three-pillar strategy consists of a balanced budget over the business cycle, the reduction of the tax burden below $40 \%$ of the GDP by 2010 and of shifting expenditure in favour of R\&D, innovation, education and infrastructure. It enhances the growth potential of the Austrian economy.

The current macroeconomic performance of the Austrian economy is favourable. In 2005, GDP per capita in purchasing power standards (PPS) in Austria was 22.5 percent above EU25 average. This value was the fifth highest behind Luxembourg, Ireland, Denmark and the Netherlands. After three years of low GDP growth, the GDP growth rate in Austria has been above EU average since 2004. In 2006, the difference is forecasted to reach half a percentage point.

In recent years, significant progress has been achieved with respect to the sustainability of public finances. Recent pension and health care reforms have put Austria in a good position. Existing long-term projections of the European Commission and the EPC indicate that Austria currently belongs to the group of countries with a low risk with regard to the sustainability of public finances.

The Austrian NRP envisages measures in order to reduce the tax burden below $40 \%$ in the year 2010 and, at the same time, to rearrange public expenditure in favour of growth enhancing expenditures like Research and Development, education or infrastructure.

According to a simulation undertaken with the dynamic computable general equilibrium model of the IHS (TAXLAB) for the Austrian economy, reducing the tax ratio by one percentage point would result in a sustainable medium term increase in real GDP by nearly $2 \%$. Additional 40.000 jobs would be generated via the reduction in the income tax rates.

The results document the potential of further tax reforms of the Austrian economy. Furthermore they also point to the implicit costs of expenditures that have to be financed via an increase of income taxation. Although tax cuts are important to improve incentives to work 
and invest, they should not be deficit-financed, since rising budget deficits have to be financed by future expenditure cuts or tax increases. Given that the general government budget balance currently shows a deficit above one percent of GDP significant tax reductions are regarded as unrealistic in the near future.

\section{Microeconomic Policy}

\section{Key Policy Area 2: Research and Development, Innovation}

Endogenous growth theory suggests that R\&D and innovation (as well as human capital) results in knowledge creation, which leads to technological advancement and is thus a major source of economic growth. Empirical testing affirms this and shows significant positive effects of R\&D and innovation on growth. Within overall efforts, business-performed R\&D and innovation has shown to be the driving force of technological advancement, at least in the short to medium perspective.

A mix of direct and indirect measures promotes R\&D and innovation targets. Government actions aim at fostering business R\&D and leverage private investment, at attracting foreign investment (Headquarter policy), at restructuring the use of funds and at efficient financing and at providing funds for international exchange, young academics and strategic research.

We estimate that the combined efforts in the field of R\&D and innovation - based on literature findings and the assumption of an increasing share of business $R \& D$ and innovation - will create a long term growth effect of approximately 0.1 percentage points of GDP. Note, however, that according to the literature the effects will become effective with a considerable time lag. Empirical studies indicate that growth will be affected with a delay of 7 to 20 years.

It is assumed that employment effects from R\&D and innovation may be limited to indirect effects as such measures primarily raise the productivity level of employees and the overall efficiency of an economy.

Note, however, that empirical estimates of the impact of R\&D on economic growth and employment vary considerably. The results presented here should be regarded as conservative approximations of potential effects.

\section{Key Policy Area 3: Infrastructure (including Broadband)}

Endogenous growth theories suggest that infrastructure is an engine of growth. Better (transport) infrastructure reduces the costs of enterprises and leads to a more efficient allocation of resources. The quantitative impact is empirically well researched. Austria has a very well developed infrastructure stock - the accession of the 10 new Member States gives 
rise to the need for further investment. Austria plans to spend 45.1 billion $€$ on transport infrastructure (29.9 bio. on rail, 15 bio. $€$ on road and 0.2 bio. $€$ on waterway projects).

As only investment figures for traffic infrastructure could be obtained, we estimated the effect of the planned traffic infrastructure investment. The results indicate an upward shift in GDP by about 1.5 percent in the long run.

\section{Key Policy Area 4: Foster Competition and SME initiative}

High investment in ICT has contributed to the surge in productivity growth in the United States since 1995. Investment into and effective use of ICT is an integral part of the Lisbon Agenda. The impacts of ICT on productivity are achieved in three ways - by raising capital stock (capital deepening), by raising total-factor productivity through growth in high tech ICT sectors and spill over effects to other sectors. Measures in the Austrian NRP are in line with the Lisbon Agenda and are seen as adequate. It is, however, difficult to quantify the exact magnitude of the initiatives in this field, as a number of studies have shown that ICT interacts with various other economic variables. The broadband initiative in combination with the successful implementation of planned e-government measures is expected to raise Austrian total factor productivity (TFP) in the long run. Eventually, an increase in economic growth can be expected, which could also positively affect employment demand. This last effect, however, is ambiguous, as increasing productivity is not always associated with an increase in labour demand, depending on whether the productivity increase is driven by rationalization or not.

With respect to market capitalisation and domestic credit to the private sector, Austria ranks below EU-15 average; the performance of the Austrian stock market, however, is in the top third of EU-15. Initiatives in the field of financial markets are embedded in coherent strategies of the European Union; the implementation of measures has so far been in time. The actions listed in the NRP, in particular FSAP and SEPA, constitute an integral part of EUwide programmes to fasten financial market integration. Since the impact of the actions set in 2006 will be realized only in the long term (and probably not be distinguishable from actions in the same programme taken in 2005 and 2007), we can only give an extremely rough estimate based on empirical studies reviewed above. Provided all FSAP and SEPA actions are successfully implemented, long-term potential economic growth may be increased marginally.

The adverse effects of collusive behaviour of firms are theoretically and empirically extensively documented. Current activities bring Austrian law in line with European Community guidelines and administrative procedures have been simplified. Changes to competition law are not expected to bring any direct benefits in terms of employment and economic growth. Yet, a better functioning of competition law is expected to exert indirect positive effects. 
The increased openness of the economy has a positive impact on economic growth and international trade has an economically significant and statistically robust positive effect on productivity. There also are significantly positive aggregate scale effects. The external sector of the Austrian economy has had an excellent performance in recent years: on average exports have increased by $3.1 \%$ in real terms (GDP growth amounted to $2.1 \%$ ). In the current and next year, foreign trade will remain a major source of growth in the Austrian economy. The Institute for Advanced Studies (IHS) expects that exports will contribute, on a yearly average, 3.3 percentage points to the GDP growth rate. Due to the efforts of the initiative "go-international", which supports Austrian firms in improving international competitiveness, the export of services - at present still quite small - might gain importance.

Due to the economic structure of the European Union targeted measures for SMEs are essential. Issues to be addressed in this context are the costs of financing, taxation of SMEs and the lowering of administrative barriers. Important Austrian measures are the SME initiative 2006, ongoing programmes undertaken by AWS and the implementation of the standard cost model to reduce the administrative burden. A model simulation for the prospective impact of reduced regulation costs of businesses suggests that real GDP may be increased by $3 / 4$ percent and additional 12.000 jobs may be created, if the targets of the NRP are met. Austrian initiatives promise positive effects in accordance with the European Union strategy. The focused actions seem to correspond well to the perceived problems of the Austrian firms and can therefore be regarded as adequate.

\section{Key Policy Area 5: Environmental technologies and efficient resource management}

As the Lisbon Strategy aims at a sustainable increase in the growth potential of member states, closer attention has to be given to the environmental implications of the economic growth in the medium to long term. According to endogenous growth theory, economic growth is sustainable if new technologies decrease the ratio of pollution per economic output. The priority of initiatives in the field of environmental policies consequently is to reconcile economic growth with environmental conditions.

The development, the implementation and the use of environmental technologies, however, may also generate positive growth and employment effects. According to endogenous growth theory and studies on environmental industry, investment in environment technologies has a high value added, creates jobs and contributes to exports and the substitution of imported fossil energy by domestic renewable energy.

Environmental industry, including modern "clean technologies", is a growing sector in Austria and Austrian enterprises have good export positions on the international market. In its report, the European Commission approved of the Austrian coherent strategies to boost innovation and environmental technology. 
The European comparative study ECOTEC supports the view that EU eco-industries create employment both in a direct and indirect way. Effects on employment and value added of investment in renewable energy and green electricity facilities can either be positive or negative, taking into account direct and indirect effects as well as short and long-term effects.

The share of renewable energy sources in gross domestic energy consumption in Austria increased from 1990-2003. In 2003, Austria held fourth place among EU 25 countries, with a share of around $20 \%$. In 2005 , the share amounted to $22.12 \%$. In 2004 , Austria was the country with the second lowest energy intensity among EU-15 countries, due to the use of energy saving environmental technologies.

To obtain the net effect of investment in and operation of new green electricity installations, the positive effect on employment and value added has to be compared with the negative indirect effect resulting from the reduction of disposable income. While the positive effects of green facilities appear in the short run, negative indirect effects become visible in the long run only.

\section{Labour Market and Employment Policy}

\section{Key Policy Area 6: Labour Market and Employment Policy}

Generally, the situation of the Austrian labour market is favourable in terms of the overall trends regarding unemployment or employment growth. Moreover, the long-term unemployment is still relatively small in an EU-wide comparison.

Employment levels are high in total and for women in all age groups. With regard to older workers, however, a significant employment potential is not exploited, as participation rates remain persistently at unacceptable low levels. Despite considerable reform efforts in recent years, policies have failed to lift effective retirement age in Austria significantly.

With regard to gender specific differences Austria performs well in terms of female participation. Female employment and activity rates are above the EU-averages, the female unemployment rate and the employment rate are beneath. This, of course, does not apply for women in all groups. Generally, older women and women with low educational attainment are less integrated. While the gender employment gap is less discernible in the total population, a high gender pay gap can still be identified especially in the private sector and for older workers.

Special attention should be paid to the development of youth unemployment. Although youth unemployment is still beneath EU-25 and EU-15 averages, it has been increasing dramatically in recent years. Starting at an unemployment ratio of $2.8 \%$ in 2000 , the 
unemployment rate for the age group between 15 and 25 was $6.1 \%$ in the year 2005 . This applies to both men and women.

The Austrian labour market performs rather homogeneously in terms of territorial and regional disparities. There already exists a high degree of territorial cohesion regarding employment and unemployment rates.

In recent years, the Austrian government has undertaken considerable efforts - along the lines of the Employment Guidelines - to improve the functioning of the labour market und to assist persons on the labour market in their successful search for adequate jobs. On top of these programmes in operation, additional measures have been implemented in connection with the NRP. The composition of the NRP measures adequately reflects the identified problem areas on the Austrian labour market.

Based on existing evaluations of comparable labour market initiatives at national and international levels, the potential impact of the NRP can be roughly estimated. Given the available figures for additional participants in various types of labour market programmes, additional employment of around 30.000 persons could be generated. This may result in an increase of real GDP of about $1 / 2 \%$. It should be noted, however, that these figures are a very rough first estimate and that they should be regarded as an upper limit of the potential impact of the NRP.

\section{Key Policy Area 7: Education and Further Training}

With respect to the main indicators used for education and further training, Austria performs well by EU comparison. Most Lisbon targets for 2010 already have been met in Austria.

According to available indicators, expenditure for as well as participation in education and further training in Austria do not seem to be problematic. Apparently, minor actions will be sufficient to ensure participation in further education and the attainment of 2010 targets. Taking into account that indicators used in this report rely on 1999 data and that, in the meantime, certain measures have been enacted, intervention may not be necessary at all if the mere goal is to reach 2010 targets.

Still, other European member states perform better than Austria, and orientation should always be towards the best. In Poland, for example, the percentage of early school leavers is only $5.5 \%$. If Austria tries to reach this benchmark by 2010 , additional efforts have to be made.

Measures in the context of education and further training definitely contribute to employment and growth, but in a more indirect way and with a mid-term perspective. Stronger emphasis on direct qualification measures, especially in the field of further training, and with respect to 
18 - Evaluation of the NRP/I H S

basic qualifications on upper secondary level in addition to the measures defined until now are expected to boost employment perspectives of participants and therefore produce a more direct effect on employment. 


\section{$1 \quad$ Background and Evaluation Framework}

At the Lisbon European Council in March 2000 the European Union set a strategic goal for the next decade "of becoming the most competitive and dynamic knowledge-based economy in the world capable of sustainable economic growth with more and better jobs and greater social cohesion"1. Yet, the Midterm Review of the Lisbon Strategy in 2005 showed only limited success and the strategy was relaunched with a new focus on growth and employment.

A key element of the new Partnership for Growth and Employment are the National Reform Programmes (NRPs) ${ }^{2}$ to be drawn up by each Member State which outline economic reform measures. These reform programmes are based on 24 Integrated Guidelines and are tailored to the specific national needs and situation of each Member State and promote growth and employment within a three-year planning period (currently 2005- 2008).

In May 2005, the Austrian Federal Government launched a reform dialogue with the social partners, the parties represented in Austrian Parliament, the representatives of the Länder, the scientific community, business and industry. As a result, the first "Austrian Reform Programme for Growth and Jobs" was adopted by the Austrian Parliament in October 2005. In accordance with EU targets, it comprises three main areas: macroeconomic policy for growth and jobs, microeconomic and structural policy to foster EU growth potentials and employment guidelines for more and better jobs.

Within these three main policy areas and based on the Integrated Guidelines, Austria has identified seven key strategic areas: (1) sustainability of public finances, (2) labour market and employment policy, (3) research and development, innovation, (4) infrastructure initiative, (5) fostering competition and SME initiative, (6) education and further training and (7) environment. The key areas comprise more than one hundred separate actions, most of which were already implemented in 2005 or 2006 (Figure 1).

Annual reporting to the European Commission and the Council is meant to secure an effective, timely and comprehensive implementation of the National Reform Programmes and gives the Council the opportunity to stress specific areas for priority actions. In march 2006 meeting, the Spring European Council agreed on a special focus on investment in knowledge and innovation, business potential (especially of SMEs), the creation of more employment opportunities and an efficient and integrated EU energy policy. ${ }^{3}$

\footnotetext{
${ }^{1}$ European Council (2000), Presidency Conclusions, Lisbon European Concil, 23 \& 24 March 2000, point 5.

${ }^{2}$ European Concil (2005), Presidency Conclusions of EC in Bruxelles, 22 \& 23 March 2005, point II.

${ }^{3}$ European Concil (2006), Presidency Conclusions of EC in Bruxelles, 18 May 2006, point 15.
} 
Figure 1: Austrian NRP target areas (key strategic areas for policy intervention)

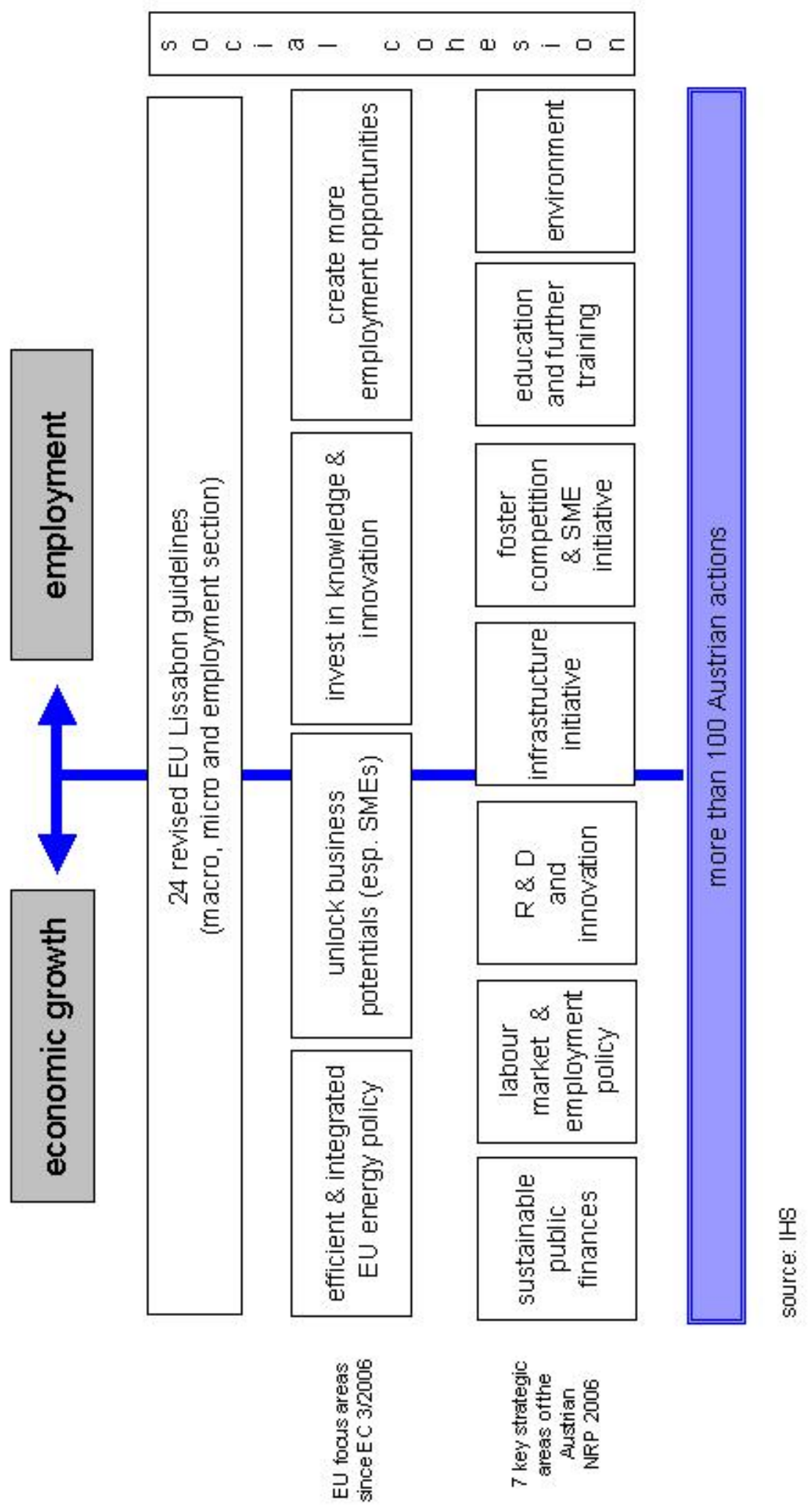


This evaluation of the Austrian National Reform Programme by the Institute of Advanced Studies was undertaken in autumn 2006 - at the same time as the first annual progress report to the Commission was submitted. It presents a first complete analysis of the expected growth and employment effects of all NRP actions and their interactions within the Austrian economy. Note yet that due to the short time after its implementation and therefore lack of data on changes in output variables, this report tries to provide first estimates of expected effects to give a grasp of the orders of magnitude of the potential impact of the Austrian NRP.

The evaluation progressed in four steps: First, and based on economic literature and theory, the seven key strategic areas of the NRP were analysed to identify potential effects of the underlying measures on economic interactions and growth and employment (Figure 2).

In a second step, the current situation and recent developments in Austria's key strategic areas were assessed. Already observable effects of the Austrian NRP measures were described and expected effects - if no data was available yet, if the effects were indirect and difficult to assess or if effects of measures were expected to show in the medium to long run only - were verbally outlined. Based on a simplifying graphic representation of economic interactions (Figure 3), charts were created to visualize the expected effects of measures in the seven core areas (see beginning of each section).

Thirdly, the NRP measures were linked to the development of output parameters (for example, structural indicators) in order to identify their contribution to EU or Austrian targets. The measures of the Austrian NRP were evaluated according to the 24 EU Integrated Guidelines and results were subsumed under the three main policy fields (macro, micro and employment).

Finally, based on existing cross-country analyses and case studies as well as economic theory and country-specific information, the (expected) effects of the NRP on economic growth and employment were estimated. For some NRP policy fields, it was possible to identify quantifiable results; for others, the lack of data only allowed to estimate the realized progress toward EU targets and to present qualitative results. 
Figure 2: Effects of NRP on Aggregate Supply and Demand

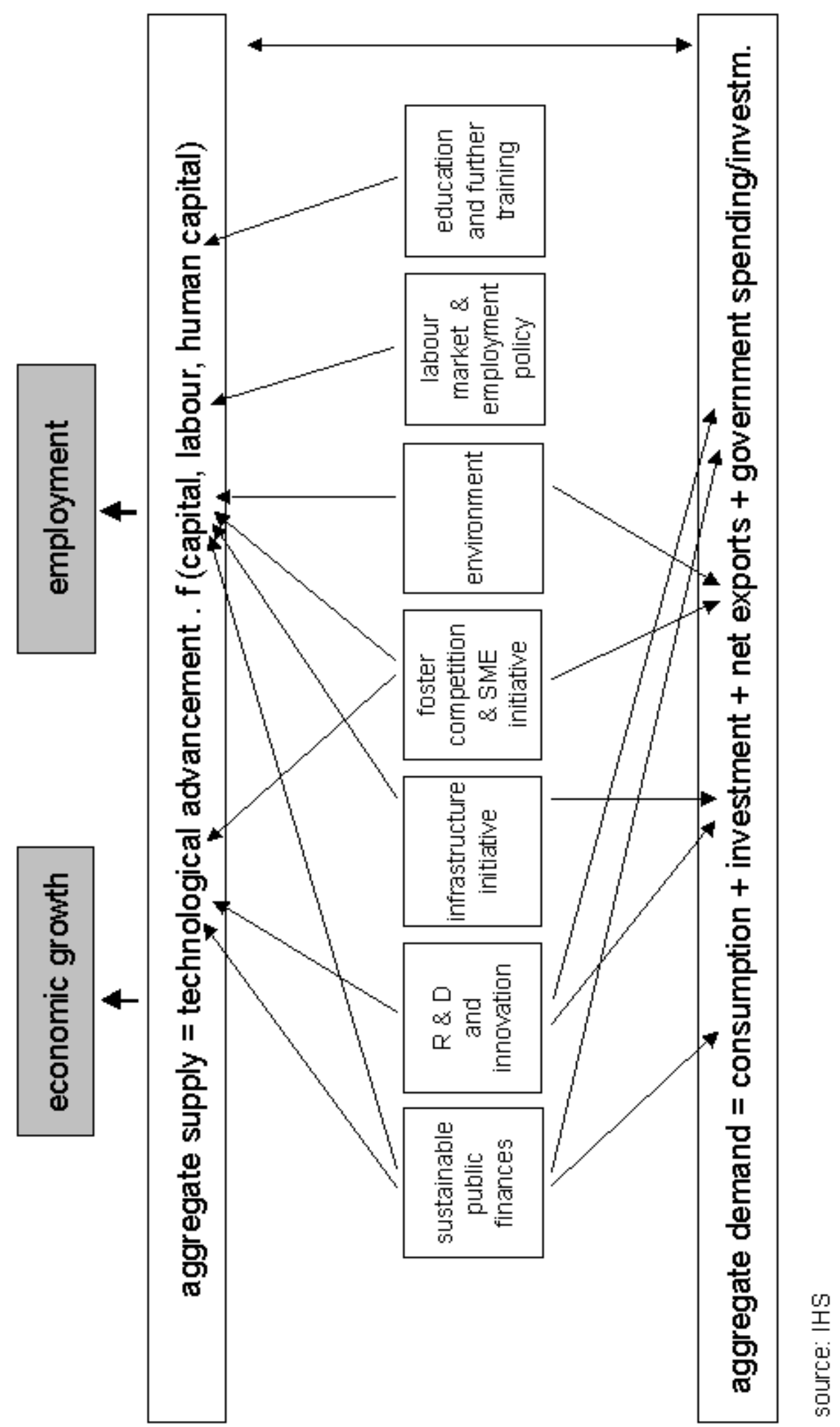


Figure 3: Model of Economic Interactions (basic structure)

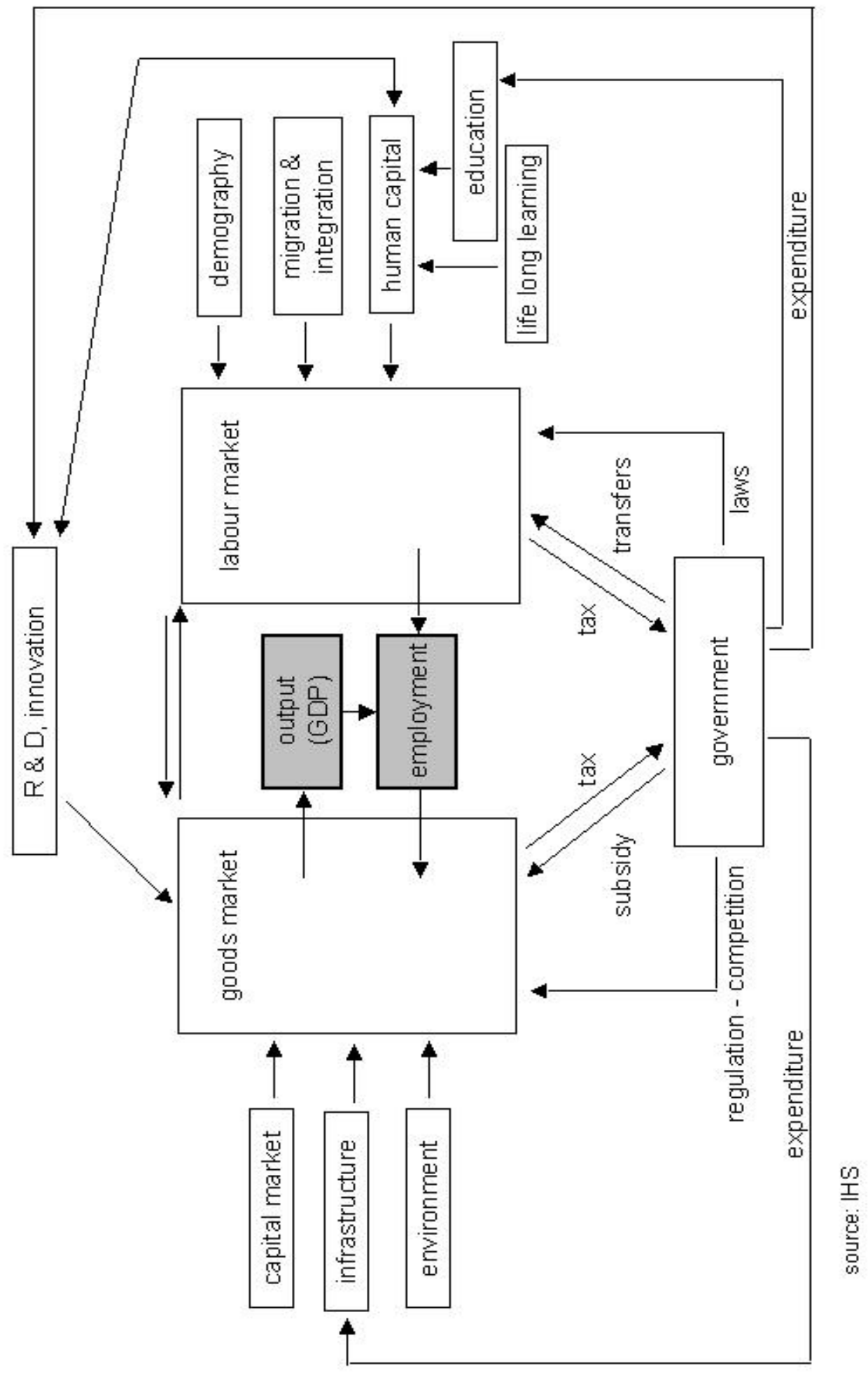




\section{Effects of NRP on Aggregate Supply and Demand (see Figure 2)}

In economic theory, growth and employment are defined by aggregate supply and demand. The actual level of GDP is determined by the intersection of the supply and demand curves.

A general form of a production function may represent aggregate supply

$$
Y_{s}=A \cdot f(C, L, H C)
$$

where aggregate supply $\left(Y_{s}\right)$ is determined by technological advancement $(A)$, the amount of capital $(\mathrm{C})$ and labour $(\mathrm{L})$ and human capital $(\mathrm{HC})$ used in the production process.

The aggregate demand function may be described as the sum of private consumption (C), investment $(\mathrm{I})$, net exports $(\mathrm{X})$ and net government spending and investment (GOV):

$$
Y_{d}=C+I+X+G O V
$$

As can be seen from the above production function, aggregate supply or output (GDP) relies on technological advancement and capital input that are both based on sustainable public finances (that enhance growth potentials of GDP by shifting public expenditures to R\&D, education and infrastructure investment) and the influence of microeconomic policy measures such as infrastructure, R\&D and innovation, fostering competition and SMEs and environmental concerns. Labour supply, and its quality - which is defined by human capital is the third main input factor. Apart from demographic developments, migration and integration, it is mainly determined by labour market and employment policy and education and further training.

On the demand side, macroeconomic policy influences both consumption and government spending. Microeconomic policy has influence on investment and net exports. The actual level of GDP is determined by the interaction of aggregate supply and demand.

\section{Model of Economic Interactions (basic structure, see Figure 3)}

This simple model used for the description of economic interactions consists of a goods market, a labour market and a government sector. Several factors influence market behaviour and outcome, thereby determining output (GDP) and employment.

The labour market is influenced by the number of workers (quantity) available - which in turn depends on demographic developments, migration and integration - and the quality of the labour force - which depends on existing human capital, education and life long learning. The government sector influences the labour market through taxes and transfers, laws and regulations and - in a more indirect way - through spending on education and R\&D and innovation (which is assumed to increase human capital and thus productivity). Wages and 
prices also determine labour supply, in the sense that they set consumption restrictions that can be shifted by offering more "hours".

R\&D and innovation, the functioning of the capital market, investment in and the existence of infrastructure and environmental policy, influence the goods market in our model. The government sector exerts influence trough taxes and subsidies as well as defining the framework for regulation and competition and expenditure on infrastructure.

Both employment and output are influenced by each other. The outcome on the goods market, which is influenced by employment, determines output (GDP). Employment is mainly the result of labour market interactions but also output production.

The basic model is used to describe economic interactions due to NRP measures (grouped into the seven key strategic areas) and a chart with the expected effects can be found at the beginning of each section. A final attempt to show all NRP effects at the same time reveals the expected interdependencies and spill over effects encountered in real life. 



\section{Macroeconomic Policy}

\section{Summary}

An overall assessment of the macroeconomic policy section in the NRP shows that the macroeconomic policy is coherent and that tax cuts support employment and GDP growth. The Austrian three-pillar strategy consists of a balanced budget over the business cycle, the reduction of the tax burden below $40 \%$ of the GDP by 2010 and of shifting expenditure in favour of R\&D, innovation, education and infrastructure. It enhances the growth potential of the Austrian economy.

The current macroeconomic performance of the Austrian economy is favourable. In 2005, GDP per capita in purchasing power standards (PPS) in Austria was 22.5 percent above EU25 average. This value was the fifth highest behind Luxembourg, Ireland, Denmark and the Netherlands. After three years of low GDP growth, the GDP growth rate in Austria has been above EU average since 2004. In 2006, the difference is forecasted to reach half a percentage point.

In recent years, significant progress has been achieved with respect to the sustainability of public finances. Recent pension and health care reforms have put Austria in a good position. Existing long-term projections of the European Commission and the EPC indicate that Austria currently belongs to the group of countries with a low risk with regard to the sustainability of public finances.

The Austrian NRP envisages measures in order to reduce the tax burden below $40 \%$ in the year 2010 and, at the same time, to rearrange public expenditure in favour of growth enhancing expenditures like Research and Development, education or infrastructure.

According to a simulation undertaken with the dynamic computable general equilibrium model of the IHS (TAXLAB) for the Austrian economy, reducing the tax ratio by one percentage point would result in a sustainable medium term increase in real GDP by nearly $2 \%$. Additional 40.000 jobs would be generated via the reduction in the income tax rates.

The results document the potential of further tax reforms of the Austrian economy. Furthermore they also point to the implicit costs of expenditures that have to be financed via an increase of income taxation. Although tax cuts are important to improve incentives to work and invest, they should not be deficit-financed, since rising budget deficits have to be financed by future expenditure cuts or tax increases. Given that the general government budget balance currently shows a deficit above one percent of GDP significant tax reductions are regarded as unrealistic in the near future. 
Figure 4: Effects of NRP on Economic Interactions - Macroeconomic Policy

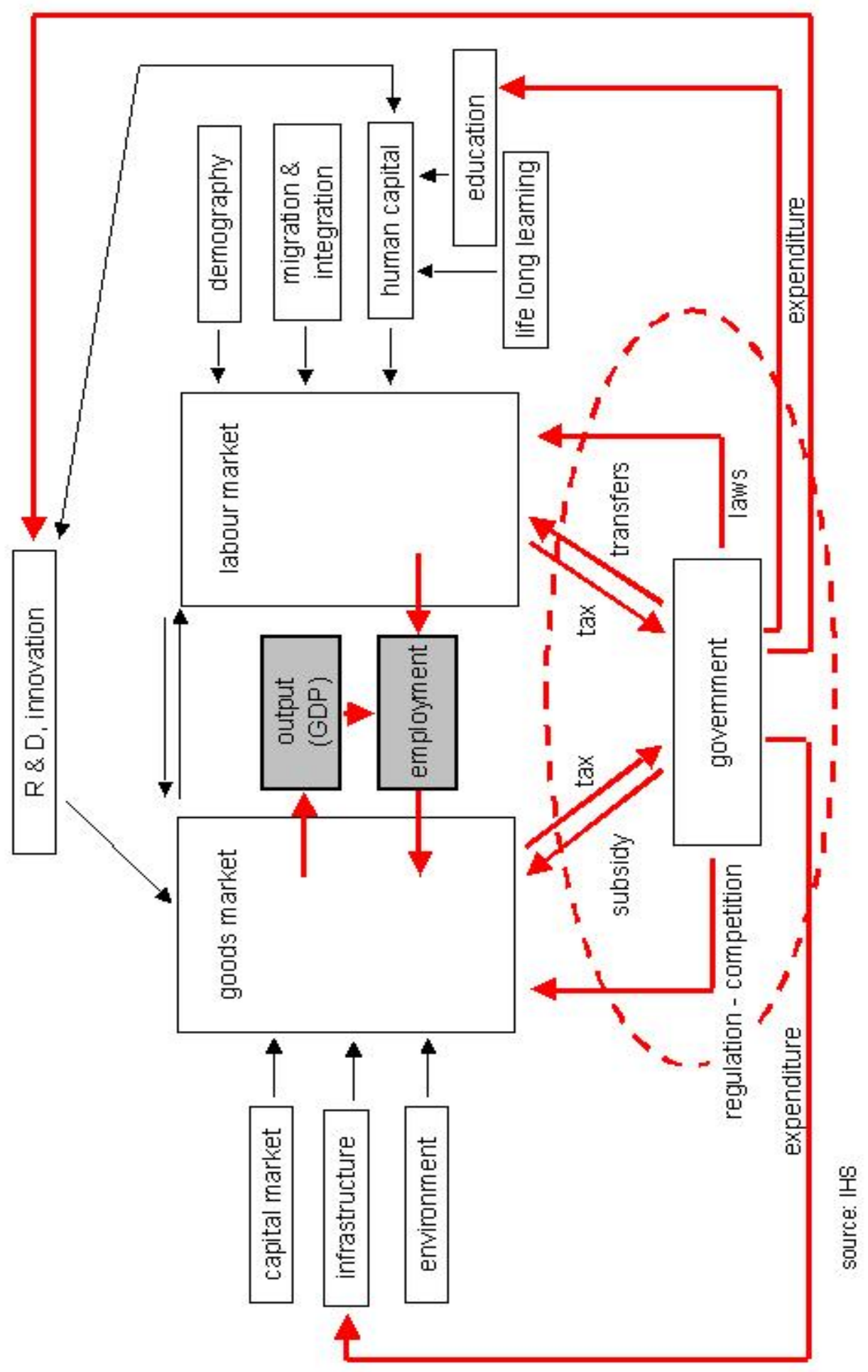




\section{Current situation}

In 2005, GDP per capita in purchasing power standards (PPS) in Austria was 22.5 percent above EU-25 average (Table 2). This value was the fifth highest behind Luxembourg, Ireland, Denmark and the Netherlands. After three years of low GDP growth, the GDP growth rate in Austria has been above EU average since 2004. In 2006, the difference is forecasted to reach half a percentage point (

Table 3).

In 2001, 2002 and 2004, fixed capital formation in Austria was rather sluggish. The investment-to-GDP ratio has fallen behind EU average since some Member States - i.e. the new Member States in Central and Eastern Europe - have recently experienced dynamic capital formation. Even if physical capital has become less important in knowledge-based economies, a continuous renewing of the capital stock is still essential to remain at the technological frontier. The recent recovery of fixed capital formation will, therefore, help to strengthen future growth potentials.

Regarding public finances, Austria is in a better position than the EU25 average (Table 4): The government budget was balanced in 2001 and nearly balanced in 2002 (not shown in the table). Between 2003 and 2005, budget deficits in the range of 1.2 to 1.6 percent of GDP were the result of moderate growth, several packages created to stimulate the economy in years of low GDP growth as well as the 2004 and 2005 tax reforms. Due to high tax revenues, the 2006 budget deficit will be lower than proposed. The budget deficit is expected to be balanced by 2008 .

At 62.6 percent, the debt-to-GDP ratio is currently above the 60 percent reference level of the Stability and Growth Pact (SGP), but is expected to decline in the near future. Compared to the EU average, the situation of public finances in Austria is relatively comfortable. On EU average, the budget deficit - both the actual figure and in cyclically adjusted terms - is higher, and this also pertains to the debt ratio. Nevertheless, and in particular against the backdrop of an ageing society, the debt level in Austria has to be further reduced. In addition, sound public finances are a prerequisite for further sustainable tax cuts and increasing R\&D expenditure.

While Austria is in a better position than EU average with respect to the budget balance, the tax ratio (taxes and social security contributions as a percentage of GDP) is still comparatively high (Table 5). The recent tax reform has reduced the tax burden for households and companies. Further alleviations seem appropriate, although the reduction of the budget deficit should be given priority. 


\section{Evaluation of NRP measures}

The Austrian NRP measures in the field of macroeconomic policy are subsumed under the main focus of sustainability of public finances. Public finances are regarded as sustainable if the current public debt and the discounted value of future expenditures including the budgetary impact of ageing populations are covered by the discounted value of future government revenues. ${ }^{4}$ The Austrian NRP strategy to secure sustainable public finances rests on three pillars: a balanced budget over the business cycle, the reduction of the tax burden to under 40 percent of GDP by 2010 and enhancing the growth of potential GDP by shifting public expenditures to R\&D, education and infrastructure investment.

In view of an ageing population, securing long-term sustainability of public finances poses a major challenge for fiscal policy-making. A rising share of pensioners in the population causes several challenges:

(1) If the overall level of government expenditure is not altered, the increasing pension expenditure will have to be financed either by rising social security contributions, tax increases or cuts in other fields of expenditure. In such a situation, there will be little scope for expenditure on R\&D, education or infrastructure. Yet, these expenditures are a key component for future GDP growth. A rising share of pension expenditure endangers such growth potentials. (2) If, on the other hand, increasing pension expenditure is financed by rising employers' social security contributions, non-wage labour cost will rise. As a reaction, employment will be reduced with negative effects on GDP growth and public finances. Higher unemployment will induce higher unemployment benefits whereas social security contributions will decline with the falling number of contributors. This further aggravates the financial strain on the social security system. (3) As an alternative financing mode, social security contributions of employees may be increased. This will induce higher wage claims by trade unions and also result in declining employment. (4) The decoupling of the social security system from wages is another alternative. In this case, social transfers will (at least partly) be financed by taxes instead of contributions. Rising pension expenditures will then depend on tax increases, which reduces the incentive to work, invest or produce. (5) It is also conceivable that the rising pension expenditure is deficit-financed. In such case, the climbing debt level will require increasing interest payments and the ability of fiscal policy to shift funds for future growth will be reduced.

Summing up, measures curbing the growth of pension expenditure are essential for future GDP growth and employment. Confining age-related expenditures leaves room for manoeuvre in the areas of public infrastructure investment, research and development and education.

\footnotetext{
${ }^{4}$ European Commission (2006), The long-term sustainability of public finances in the European Union. European Economy 4/2006.
} 
Recent pension reforms have put Austria in a good position. Starting from a value of 13.4 percent of GDP in 2004 (one of the highest within the EU), the relation of pension expenditure to GDP is forecast to decline to 12.2 percent (one of the lowest among EU25 countries) by 2050 (Table 7). Health care expenditure as a percentage of GDP is projected to increase in line with EU average, while expenditure for long-term care is expected to rise slightly above average. Public finances benefit from increases in employment rates that result in lower expenditure on unemployment benefits. In addition, the declining share of the younger population results in decreasing education-related expenditure. However, these budgetary alleviations are of a smaller magnitude than the aforementioned age-related expenditure increases for pensions, health care and long-term care. Overall, the age-related expenditures in Austria will grow very moderately until 2050. The increase will be well below the EU average.

The European Commission assesses the long-run sustainability of public finances, taking account of the current budget balance and debt level as well as future age-related expenditure. ${ }^{4}$ Sustainability is measured on the basis of two indicators: (1) The first indicator is constructed over a finite horizon up to 2050 and takes account of any additional adjustments required to reach a debt target of 60 percent of GDP in 2050. (2) The second indicator is based on the inter-temporal budget constraint over an infinite time horizon. According to these indicators, Austria's sustainability gap amounts to 0.1 percent of GDP (respectively 0.3 percent for the second indicator), meaning that the primary balance in 2050 should be higher than forecasted under current policies.

Due to the recent pension and health care reforms, the overall assessment shows that Austria belongs to the EU countries with a low risk with regard to sustainability of public finances. Influenced by the expenditure-reducing effects of the recent pension reform, Austria's long-term budgetary impact of ageing is below EU average.

Sustainability of public finances not only pertains to the impact of ageing-related expenditure. A shift of expenditure from consumptive activities to investment and a reduction of the tax burden are also important elements. Tax cuts, both for companies and private households, increase the incentive to engage in economic activity. The tax reform (2004/5) reduced the corporate income tax rate from 34 to 25 percent and has raised the attractiveness of Austria as a business and investment location.

Summing up, the 2004/2005 tax reform has contributed to GDP growth and employment and will continue to do so in the future. However, considering the development of tax reductions in other European countries, further tax cuts may become necessary. 
According to existing estimates ${ }^{5}$, fiscal measures undertaken between 2002 and 2006 (two stimulus packages, growth and competitiveness package, tax reform of 2004 and 2005, R\&D initiatives, regional employment and growth initiative, and employment initiative) have raised real GDP by $1.4 \%$ and the cumulated employment effect is estimated at 63,000 employees.

In 2006, the budgetary impact of the 2004/2005 tax reform (without effects of aforementioned stimulus and growth packages) amounts to 3.6 billion $€$. The permanent tax relief for companies and households from 2007 onwards is expected to be 3 billion $€$ annually.

The macroeconomic effect of the recent tax reform, a GDP increase of 0.06 percent in 2004 has been estimated; the cumulative effect until 2008 is expected to be 0.43 percent. The cumulative employment effect until 2008 is estimated at 4,300 additional jobs. ${ }^{6}$

The recent tax reform reduced the overall tax ratio (taxes and social security contributions as percentage of GDP) from 44.8 percent in 2001 to 42.2 percent in 2005 (Table 5). In 2006, a level of 41.8 percent is envisaged. With EU25 average lower than 40 percent (39.5 percent in 2004), there is still scope for further tax relieves in Austria - with the priority condition of a balanced budget. To ensure financing in areas of future growth potentials, future tax cuts have therefore to be accompanied by corresponding expenditure reductions. Although tax cuts are important to improve incentives to work and invest, they should not be deficitfinanced since rising budget deficits have to be financed by future expenditure cuts or tax increases. It is important to achieve a balanced budget over the business cycle and to reduce debt levels. In 2005, the deficit-to-GDP ratio in Austria amounted to 1.5 percent. In spite of tax shortfalls after the tax reform, the deficit in 2006 is expected to decline to 1.2 percent of GDP because of high tax revenues brought about by the buoyant economy.

At 63.4 percent, the debt-to-GDP ratio at the end of 2005 - although declining - still exceeds the Maastricht reference value of 60 percent. Reducing the debt level is important to strengthen the resilience of public finances to adverse shocks and to reduce long-term sustainability risks.

In its recent Stability Programme, the Austrian Government plans to achieve in 2008 both a balanced general government balance and a debt level below 60 percent of $\mathrm{GDP}^{7}$ Reducing the budget deficit while cutting taxes and raising public investment in infrastructure (i.e., broad-band internet, roads and railway connections), R\&D and education requires additional spending restraints. Accordingly, the reform of the administrative sector proceeds with a shift from input to output orientation, the extension of e-government, modern management

\footnotetext{
${ }^{5}$ Österreichisches Reformprogramm für Wachstum und Beschäftigung. 1. Umsetzungsbericht 2006.

${ }^{6}$ Breuss, F., Kaniovski, S., Schratzenstaller, M. (2004), Steuerreform 2004/05 - Maßnahmen und makroökonomische Effekte. WIFO-Monatsbericht 8/2004.

${ }^{7}$ BMF (2005), Austrian Stability Programme. Update for the period 2005 to 2008.
} 
methods in public services, transparency of true cost and the centralisation of back office work. Among other measures, public employment shall be reduced by 15,667 full time equivalents and employees will be shifted to more productive tasks. As part of the administrative reform package, the federal government, governments of the federal states and municipalities agreed to save 1.886 billion $€$ in the period from July 2005 to 2010 .

The quality and the sustainability of public finances were also improved by the 2005 health reform. Improving administrational and organisational issues in hospitals and strengthening the coordination between them and practitioners should result in savings of 300 million $€$ per year. The expenditure cuts in the health sector were necessary to dampen the projected increase in health-related expenditure due to population ageing (see Table 7). Funds made available by the health reform can be re-directed towards investment in future growth potentials. In addition to the planned cost savings, the health reform envisages additional funds of 300 million $€$ per year for the health system which will be financed by increased tobacco taxes, raised health insurance contributions $(+0.1$ percentage points) and a higher maximum contribution. The raised taxes and contributions increase non-wage labour costs and thereby negatively affect growth and employment, as companies will react by reducing staff. Although the amount of the measures is small, they are nevertheless problematic as they impair the international competitiveness of Austria's companies, which already face comparatively high wages and non-wage labour costs.

Both the administrative and the health reform aim at making funds available for future tax cuts and investment in growth potentials (public infrastructure, education and R\&D). The Austrian Stability Programme envisages a shift of expenditures from general public services to expenditure on growth potentials of the Austrian economy. In 2004, the relation of expenditure on general public services to GDP in Austria amounted to 8.4 percent (Table 8). While this value was already below EU average, the ambition to further reduce the share of public services in total government expenditure has to be supported: Despite the recent pension reform, social protection still remains the largest expenditure category, accounting for 42 percent of total government expenditure. It will, therefore, be essential to closely watch the cost of social protection, raise the employment rate (particularly for older workers) and further reform the health sector in order to cope with technical progress and expenditure related to increasing life expectancy.

Infrastructure investment exerts positive growth and employment effects both in the short and in the long run. In the short run, i.e. in the business cycle frequency, investment in infrastructure stabilises employment - particularly in the construction industry. In the long run, road and railway infrastructure is necessary to reduce deficiencies in the accessibility of certain regions in Austria as well as the eastern neighbouring countries. Increased infrastructure investment is therefore important to create employment and enhance the longrun growth potential of the Austrian economy. 
Overall, the macroeconomic policy section of the NRP is coherent. The tax cuts support fixed capital formation and private consumption and thus employment. A balanced budget over the business cycle, limiting the increase of ageing-related expenditures as well as the shift of expenditures from consumption to education, R\&D and infrastructure investment will enhance the future growth potential of the Austrian economy.

\section{BOX 1: Simulation of an income tax rate reduction (TAXLAB)}

This part studies the economic impact of a reduction of income tax rates on GDP and the labour market. The simulation (by TAXLAB, see ANNEX) is based on the assumption that public expenditures are decreased by one percentage point of GDP. This implies that total tax revenues can be reduced by the same amount without violating the target of a balanced budget. We assume that the government reduces the revenues of the income tax by proportionally lowering the marginal income tax rates.

This reform reduces the tax wedge significantly. Individuals and firms bargain over the resulting job rent. On the one hand, individuals gain because of higher net wages; on the other hand, firms can pay lower gross wages. The higher net wages imply higher labour supply, the lower gross wages increase labour demand, so that a smaller tax wedge results in higher labour input. This, in turn, implies a higher productivity of capital, so that the reform also creates incentives for additional investment. The increment in both inputs results in a higher GDP.

Long-run results of a reduction of income tax rates are shown in Table 1. Total labour input is increased by $1.7 \%$. This result is partly caused by a higher work effort of households (e.g. individuals work full time instead of part time); the larger part, however, comes from additional jobs. In total, approximately 41 thousand new jobs will be created. The simulation also shows that all skill groups are affected by the reform, but the effect on the group of highskilled individuals is slightly larger. This stems from the fact that the tax rate of individuals with high income is reduced more heavily in absolute values. Investment of firms increases by $2.1 \%$. In total, higher labour input and higher capital stock imply an increase of GDP level by $1.9 \%$. A reduction of tax rates can thus be seen as very effective in boosting the Austrian economy.

Table 1: Growth and employment effects of the reduction of income tax rates

\begin{tabular}{|c|c|}
\hline Model results -1 & \\
\hline GDP & $1.92 \%$ \\
\hline Labour Input & $1.74 \%$ \\
\hline Additional Jobs & 40,638 \\
\hline Investment & $2.07 \%$ \\
\hline
\end{tabular}

Source: Simulation with TAXLAB 
Table 2: GDP per capita in PPS in Austria (EU25=100)

\begin{tabular}{|lllllllll|}
\hline & $\mathbf{2 0 0 0}$ & $\mathbf{2 0 0 1}$ & $\mathbf{2 0 0 2}$ & $\mathbf{2 0 0 3}$ & $\mathbf{2 0 0 4}$ & $\mathbf{2 0 0 5}$ & $\mathbf{2 0 0 6}$ & $\mathbf{2 0 0 7}$ \\
\hline Austria & 125.8 & 122.1 & 120.0 & 120.3 & 121.7 & 122.5 & 122.4 & 121.9 \\
\hline
\end{tabular}

Source: Eurostat. 2006 and 2007: forecasts.

Table 3: Real GDP growth rate

\begin{tabular}{|l|llllllll|}
\hline & $\mathbf{2 0 0 0}$ & $\mathbf{2 0 0 1}$ & $\mathbf{2 0 0 2}$ & $\mathbf{2 0 0 3}$ & $\mathbf{2 0 0 4}$ & $\mathbf{2 0 0 5}$ & $\mathbf{2 0 0 6}$ & $\mathbf{2 0 0 7}$ \\
\hline Austria & 3.4 & 0.8 & 0.9 & 1.1 & 2.4 & 2.0 & 3.1 & 2.3 \\
EU25 & 3.9 & 2.0 & 1.2 & 1.3 & 2.3 & 1.7 & 2.5 & 2.3 \\
\hline
\end{tabular}

Note: 2006 and 2007: IHS forecasts.

Sources: Eurostat; IHS (2006), Prognose der österreichischen Wirtschaft 2006-2007, Oktober 2006.

Table 4: Development of budget balance and gross debt (as a percentage of GDP)

\begin{tabular}{|c|c|c|c|c|c|c|c|c|c|c|c|c|}
\hline & \multicolumn{2}{|c|}{2003} & \multicolumn{2}{|c|}{2004} & \multicolumn{2}{|c|}{2005} & \multicolumn{2}{|c|}{2006} & \multicolumn{2}{|c|}{2007} & \multicolumn{2}{|c|}{2008} \\
\hline & AUT & EU25 & AUT & EU25 & AUT & EU25 & AUT & EU25 & AUT & EU25 & AUT & EU25 \\
\hline $\begin{array}{l}\text { General government } \\
\text { gross debt }\end{array}$ & 64.6 & 62.0 & 63.8 & 62.4 & 63.4 & 63.4 & 62.6 & 62.5 & 62.2 & 61.4 & 61.6 & 60.4 \\
\hline $\begin{array}{l}\text { General government } \\
\text { budget balance }{ }^{* *}\end{array}$ & -1.6 & -3.0 & -1.2 & -2.7 & -1.5 & -2.3 & -1.2 & -2.0 & -1.6 & -1.6 & -1.4 & -1.4 \\
\hline Interest expenditure & 3.1 & 3.0 & 3.0 & 2.8 & 2.9 & 2.7 & 2.8 & 2.7 & 2.7 & 2.7 & 2.7 & 2.6 \\
\hline $\begin{array}{l}\text { General government } \\
\text { primary balance }\end{array}$ & 1.5 & 0.0 & 1.8 & 0.2 & 1.4 & 0.4 & 1.6 & 0.7 .4 & 1.1 & 1.1 & 1.3 & 1.2 \\
\hline $\begin{array}{l}\text { Cyclically adjusted } \\
\text { budget balance }\end{array}$ & -1.0 & -2.7 & -0.8 & -2.5 & -1.0 & -1.9 & -1.3 & -1.7 & -0.5 & -1.3 & 0.0 & -1.1 \\
\hline $\begin{array}{l}\text { Cyclically adjusted } \\
\text { primary balance }\end{array}$ & 2.1 & 0.3 & 2.2 & 0.3 & 1.9 & 0.8 & 1.5 & 0.9 & 2.2 & 1.3 & 2.7 & 1.5 \\
\hline
\end{tabular}

Notes: $\quad$ * 2006 to 2008: New forecasts for Austria (updates for cyclically adjusted public balance not available); Source: BMF.

** 2007-2008: No policy change scenario. According to the Austrian Stability Programme it is planned to balance the budget by 2008 .

2008: no forecasts for EU25 available at cut-off date of this research report.

Sources: European Commission (2006), Public finances in EMU, European Economy 3/2006; European Commission (2006), Economic forecasts, Autumn 2006, European Economy 5/2006; BMF(2005), Austrian Stability Programme. Update for the period 2005 to 2008. November 2005.

Table 5: Taxes and social security contributions as percentage of GDP

\begin{tabular}{|l|lllllll|}
\hline & $\mathbf{2 0 0 0}$ & $\mathbf{2 0 0 1}$ & $\mathbf{2 0 0 2}$ & $\mathbf{2 0 0 3}$ & $\mathbf{2 0 0 4}$ & $\mathbf{2 0 0 5}$ & $\mathbf{2 0 0 6}$ \\
\hline Austria & 42.9 & 44.8 & 43.8 & 43.2 & 43.0 & 42.2 & 41.8 \\
EU25 & 41.0 & 40.2 & 39.6 & 39.6 & 39.5 & - & - \\
\hline
\end{tabular}

- no data available.

Sources: Eurostat; Austria 2004 - 2006: BMF

(ttps://www.bmf.gv.at/Wirtschaftspolitik/AktuelleWirtschaftsdaten532/_start.htm). 
Table 6: Corporate tax rates in EU25 countries in 2005 and 2006

\begin{tabular}{|l|l|l|}
\hline & $\mathbf{2 0 0 5}$ & $\mathbf{2 0 0 6}$ \\
\hline Austria & $\mathbf{2 5 \%}$ & $\mathbf{2 5 \%}$ \\
Belgium & $34 \%$ & $34 \%$ \\
Cyprus & $10 \%$ & $10 \%$ \\
Czech Republic & $26 \%$ & $24 \%$ \\
Denmark & $28 \%$ & $28 \%$ \\
Estonia & $0 \% / 24 \%$ & $0 \% / 23 \%$ \\
Finland & $26 \%$ & $26 \%$ \\
France & $33.83 \%$ & $33.33 \%$ \\
Germany & $38.31 \%$ & $38.34 \%$ \\
Greece & $24 \% / 32 \%$ & $22 \% / 29 \%$ \\
Hungary & $16 \%$ & $16 \%$ \\
Ireland & $12.5 \%$ & $12.5 \%$ \\
Italy & $37.25 \%$ & $37.25 \%$ \\
Latvia & $15 \%$ & $15 \%$ \\
Lithuania & $15 \% / 13 \%$ & $15 \% / 13 \%$ \\
Luxemburg & $30.38 \%$ & $29.63 \%$ \\
Malta & $35 \%$ & $35 \%$ \\
Netherlands & $27 \% / 31.5 \%$ & $25.5 \% / 29.6 \%$ \\
Poland & $19 \%$ & $19 \%$ \\
Portugal & $27.5 \%$ & $27.5 \%$ \\
Slovak Republic & $19 \%$ & $19 \%$ \\
Slovenia & $25 \%$ & $25 \%$ \\
Spain & $35 \%$ & $35 \%$ \\
Sweden & $28 \%$ & $28 \%$ \\
United Kingdom & $30 \%$ & $30 \%$ \\
EU25 average & $\mathbf{2 5 \%}$ & $\mathbf{2 5 \%}$ \\
\hline
\end{tabular}

Note: For the countries with differentiated tax rates, the arithmetic average has been used for the calculation of the EU25 average.

Sources: KPMG, Corporate Tax Rates Survey 2006 (http://www.kpmg.com/Services/Tax/IntCorp/CTR/EU.htm (17 October 2006); own calculations.

Table 7: Age-related expenditures (in percent of GDP) in 2004 and projections for 2030 and 2050

\begin{tabular}{|l|lll|lll|lll|}
\hline & \multicolumn{3}{|c|}{ Pensions } & \multicolumn{3}{c|}{ Health care } & \multicolumn{3}{c|}{ Long-term care } \\
& $\mathbf{2 0 0 4}$ & $\mathbf{2 0 3 0}$ & $\mathbf{2 0 5 0}$ & $\mathbf{2 0 0 4}$ & $\mathbf{2 0 3 0}$ & $\mathbf{2 0 5 0}$ & $\mathbf{2 0 0 4}$ & $\mathbf{2 0 3 0}$ & $\mathbf{2 0 5 0}$ \\
\hline Austria* $^{*}$ & 13.4 & 14.0 & 12.2 & 5.3 & 6.3 & 6.9 & 0.6 & 1.0 & 1.5 \\
EU25 & 10.6 & 11.9 & 12.8 & 6.4 & 7.4 & 8.0 & 0.9 & 1.2 & 1.6 \\
\hline
\end{tabular}

Source: European Commission (2006), The long-term sustainability of public finances in the European Union, European Economy 4/2006.

* These projections only concern the expenditure of the Federal Long-term Care Allowance Act.

Table 8: Expenditures on general public services as a percentage of GDP

\begin{tabular}{|l|rrrr|}
\hline & $\mathbf{2 0 0 1}$ & $\mathbf{2 0 0 2}$ & $\mathbf{2 0 0 3}$ & $\mathbf{2 0 0 4}$ \\
\hline Austria & 9.6 & 9.1 & 8.7 & 8.4 \\
EU15 & 11.6 & 11.2 & 11.1 & - \\
EU25 & - & - & 10.9 & - \\
\hline
\end{tabular}

-: no data available

Source: Eurostat. 


\section{Microeconomic Policy}

\subsection{Research \& Development and Innovation}

\section{Summary}

Endogenous growth theory suggests that R\&D and innovation (as well as human capital) results in knowledge creation, which leads to technological advancement and is thus a major source of economic growth. Empirical testing affirms this and shows significant positive effects of R\&D and innovation on growth. Within overall efforts, business-performed R\&D and innovation has shown to be the driving force of technological advancement, at least in the short to medium perspective.

A mix of direct and indirect measures promotes R\&D and innovation targets. Government actions aim at fostering business R\&D and leverage private investment, at attracting foreign investment (Headquarter policy), at restructuring the use of funds and at efficient financing and at providing funds for international exchange, young academics and strategic research.

We estimate that the combined efforts in the field of R\&D and innovation - based on literature findings and the assumption of an increasing share of business R\&D and innovation - will create a long term growth effect of approximately 0.1 percentage points of GDP. Note, however, that according to the literature the effects will become effective with a considerable time lag. Empirical studies indicate that growth will be affected with a delay of 7 to 20 years.

It is assumed that employment effects from R\&D and innovation may be limited to indirect effects as such measures primarily raise the productivity level of employees and the overall efficiency of an economy.

Note, however, that empirical estimates of the impact of R\&D on economic growth and employment vary considerably. The results presented here should be regarded as conservative approximations of potential effects. 
Figure 5: Effects of NRP on Economic Interactions - R\&D and Innovation

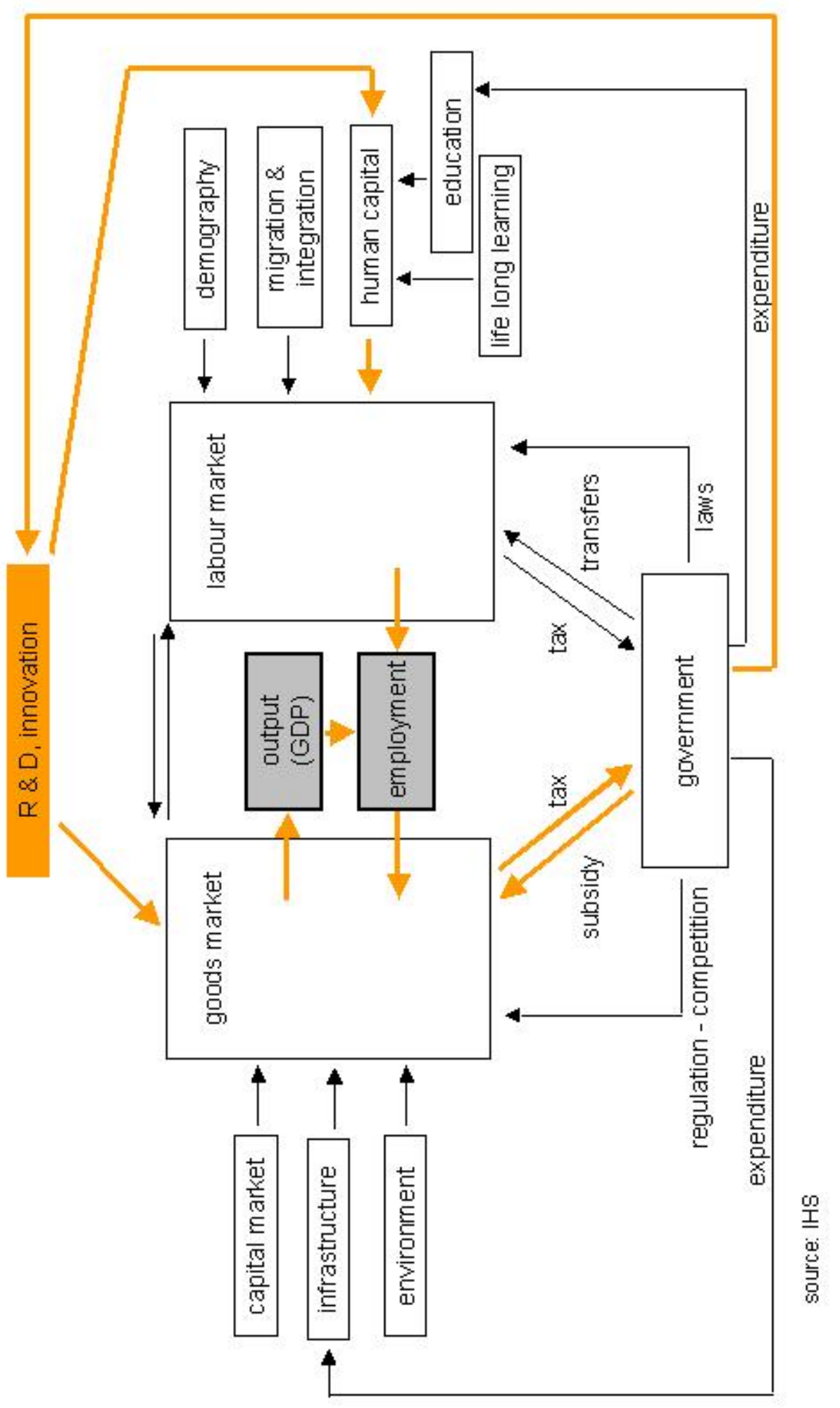




\section{Expected Effects of Investment in R\&D and Innovation:}

According to endogenous growth theories, ${ }^{8}$ continuous investment in R\&D and innovation is a major source of technological advancement that in turn improves the firms' business situation. Together with investment in human capital, such investment in "knowledge creation" translates into new production processes, new products, changes in labour demand (and supply) as well as competitive advantage. Knowledge creation and its positive spill over effects influence both the labour and product market and are considered to be main driving forces of economic growth and (indirectly also) employment growth in knowledgebased societies.

Empirical testing supports this view: Despite variations in the estimated returns of R\&D and innovation on growth (or multifactor productivity), recent economic studies have shown that high intensities of R\&D investment have a significant positive effect on the growth process.

Moreover, a large scale OECD cross-country analysis ${ }^{9}$ suggests that business-performed $R \& D$ is the driving force of the positive association between $R \& D$ intensity and output growth. This can be explained by four facts: Firstly, private investment is mainly targeted at the implementation of new innovative production processes that visibly improve business performance already in the short/medium run. Secondly, high spill over effects from business R\&D enhance the business sector's general ability to absorb technological changes (high social return). Thirdly, public R\&D investment often generates basic knowledge that will influence growth in a long run perspective only and is difficult to assess. ${ }^{10}$ Fourthly, the investment of public funds to initiate and promote private R\&D and innovation activity was shown to leverage high additional private R\&D investment ${ }^{11}$ and produces higher productivity effects than public R\&D, making such spending even more R\&D- and growth-efficient.

Estimations of growth effects of R\&D investment and innovation vary: The OECD study ${ }^{12}$ calculated $0.14 \%$ for total investment and $0.13 \%$ to $0.26 \%$ for business investment. A panel data analysis of productivity growth ${ }^{13}$ indicates that a $1 \%$ increase in business (foreign/public) R\&D generated $0.13 \%$ (respectively $0.44 \%$ and $0.17 \%$ ) in long-term productivity growth.

\footnotetext{
${ }^{8}$ Hofer H., Ragacs C., Riedel M., Schuh U., Wörgötter C., Qualität der Arbeit - ökonomische Theorie und wirtschaftspolitische Implikationen, Institut für höhere Studien, Wien, Februar 2003, p. 64ff.

${ }^{9}$ OECD (2003), The sources of economic growth in OECD countries, Paris, p. 84ff.

${ }^{10}$ This may also explain the sometimes negative association of public R\&D investment and growth which might otherwise be interpreted as public crowding out of resources.

${ }^{11}$ Schibany et al (2004), Imput Additionality Effects of R\&D subsidies in Austria, Institute of Technology and Regional Policy, Vienna, in: http://www.tip.ac.at/publications/schibany0304 RD\%20Financing.pdf.

${ }^{12}$ OECD (2003), p. 84ff.

${ }^{13}$ Guellec D. and Pottelsberghe B. (2001), R\&D productivity growth: panel data analysis of 16 OECD countries, OECD STI working paper 2001/3, Paris.
} 
It follows from the literature that effects of increased R\&D spending on growth and employment become effective only with a considerable time lag. ${ }^{14}$ As increased effort in R\&D generates additional knowledge only after some time and its application also is time consuming it has to be expected that returns to investment accrue only in the medium to long term. According to the literature the effects of R\&D on growth may lag between seven to twenty years. ${ }^{15}$

\section{Current Austrian R\&D situation:}

The Spring European Councils of Lisbon and Barcelona emphasized the importance of R\&D and innovation by setting the R\&D-target for 2010 to 3 percent of GDP, which is to be met mostly by increased business R\&D expenditure. Austria committed itself to this $3 \%$ target.

In 2006, Austria's gross domestic expenditure on research and experimental development (i.e. total expenditure on R\&D performed in Austria) is estimated to amount to $2.43 \%$ of gross domestic product (GDP) or 6240,3 million $€^{16}$

The three most important sources of funding for R\&D performed in Austria ${ }^{17}$ in 2006 are the business enterprise sector $(45.8 \%)$, the public sector $(36.9 \%)$ - the largest share being borne by the federal government $(30.8 \%)$ - and abroad (17.0\%). Funds from abroad originate mostly from European companies affiliated with domestic business enterprises that have selected Austria as their location for research, but also includes money flowing back from EU Framework Programmes for R\&D (approx. € 70 million in 2005 and 2006).

International comparison of R\&D expenditure shows that Austria's R\&D intensity (research quota) has exceeded the EU 25 average considerably in recent years. The most recent data are available for 2004, when R\&D as percentage of GDP was $1.86 \%$ for the EU25, $1.92 \%$ for the EU15 and $2.26 \%$ for Austria, which puts it in fifth rank within the EU25 countries. ${ }^{18}$ Since 1993, investment in R\&D in Austria rose twice as fast as GDP. In 2006, the average annual growth rate since 1998 amounted to $7.9 \%$ for total research investment (GERD), $7.2 \%$ for R\&D funding by the federal government and an even greater $9.2 \%$ for R\&D funding by the business enterprise sector. ${ }^{19}$

Last year's evaluation of the R\&D situation by the European Commission showed that "the planned increase in R\&D spending seems sufficient to bring Austria to $1 \%$ public research

\footnotetext{
${ }^{14}$ See Burger, Felderer (2005).

${ }^{15}$ See Stephan (1996) and Mansfield (1996).

${ }^{16}$ STATISTIK AUSTRIA (2006), press release on research an experimental development

${ }^{17}$ STATISTIK AUSTRIA (2006), press release on research an experimental development

${ }^{18}$ EUROSTAT Data (extraction 10.2006).

${ }^{19}$ STATISTIK AUSTRIA (2006), press release on research an experimental development.
} 
investment by 2010 ( $0.86 \%$ currently), but substantial additional efforts may well be needed to leverage investments from the private sector. The NRP tackles weaknesses in the innovation system and tackles them adequately by measures to improve access to finance for innovative ventures and strengthen the qualifications of the workforce." ${ }^{20}$

Accordingly, the R\&D investment strategy in the Austrian National Reform Programme (NRP) $2006-2008^{21}$ is to promote private research activity, with a special focus on SMEs. Research funding has been increased by means of direct support (e.g. general provision for the "planned $3^{\text {rd }}$ technology offensive") and tax incentives, including research premiums, improved access to finance for innovative ventures, a reform of the research incentive system and innovation-friendly public procurement. The NRP continues to promote successful Austrian R\&D measures, with a stronger focus on Lissabon targets.

\section{Development of $R \& D$ parameters ${ }^{22}$}

The R\&D intensity - measured by R\&D expenditure as \% of GDP - is the most commonly used research indicator. The Austrian research intensity rose substantially in the last years. The continuation of the extraordinary R\&D funding by the federal government substantially increased financial research resources. In addition, the business sector showed substantial R\&D increases, covering a growing portion of investment by own funds. The share of money invested from abroad declined slightly.

As for researchers in R\&D, Austrian data only exists for 1998 and 2002. The head count measuring the total number of researchers who are mainly or partly employed on R\&D showed a growing trend, especially in the business and higher education sector. The share of total employment in knowledge-intensive sectors in Austria rose over the last years and amounted to $5.05 \%$ in 2005 .

Although the number of graduates in science and technology was steadily growing over the last years, it is still markedly below EU25 as well as EU15 average. With $8.7 \%$ of tertiary graduates per 1000 of population aged 20 to 29 years, the Austrian figure in 2004 was much lower then EU25 average (12.7\%) and EU15 average (13.6\%) in the same year. The difference was more pronounced for female science and technology graduates than for male graduates - with only $4 \%$ of female graduates in 2004, Austria reached only half of EU level.

The total number of patent applications to the EPO was rising in the last years, with the exception of 2003 (for which the last EUROSTAT data is available).

\footnotetext{
${ }^{20}$ EK (2005), Yearly assessment of Austrian situation (as compared to Lissabon targets).

${ }^{21}$ Österreichische Bundesregierung (2006), Österreichisches Reformprogramm für Wachstum \& Beschäftigung, 1. Umsetzungsbericht, Wien.

${ }^{22}$ All data (unless stated otherwise): EUROSTAT data, extraction 20.10.2006, in: http://epp.eurostat.ec.europa.eu.
} 
Although venture capital investment for start-ups and early stage investment was rising in the last years and attained $0.0115 \%$ of GDP in 2005, they were lower than euro area $(0.0149 \%)$ and EU25 $(0.0223 \%)$ average. With $0.0391 \%$ of GDP venture capital investments for expansion and replacement in Austria in the same year were lower than euro area $(0.0597 \%)$ and EU25 (0.1157 \%) average.

The European Innovation Scoreboard ${ }^{23}$ evaluates and compares the innovation performance of the Member States. Based on an innovation index comprising several innovation indicators, the 2005 scoreboard shows an average innovation performance including a distinct positive trend for Austria as compared to other EU countries.

Austria's high tech exports, calculated as the share of exports of high technology products (such aerospace, computers, office machinery, electronics, instruments, pharmaceuticals, electrical machinery and armament) of total export have been a little below EU average. In 2004, high tech exports in Austria amounted to $15 \%$ of total export as compared to $18 \%$ on EU25 average.

\section{Evaluation of R\&D actions in NRP:}

Within NPR 2006, a mix of several direct and indirect measures intends to promote R\&D activities and innovation within Austria and in European networks. The most important is the third planned technology offensive (Forschungsmilliarde) that increased funds for R\&D and innovation by one billion $€$ for the planning horizon of 2007 to 2010. Some of these funds have already been made available for research in 2005 (50 million $€$ ) and 2006 (75 million $€)$. Although no measurable results can be expected at this stage, increased innovative potential and spill over effects are expected to raise GDP (and employment) in the long run.

Tax relieves (Frascati and "Freibeträge nach § 4.4.4.a EStG 1988") and research premiums increase and promote research activities and innovation. Such tax relieve seems to be an efficient tool to leverage research in the private sector, with the expected positive result of additional private funds being invested in such ventures.

A new programme for science-business partnerships (COMET) ${ }^{24}$ has been started for first tendering in October 2006. It includes three $\mathrm{K} 2$ centres, eight $\mathrm{K} 1$ centres and $10 \mathrm{~K}$ projects with governmental financing of $€ 130$ million. A second tender period for $K 1 / K 2$ is planned for 2008; tendering for K-projects are intended in 2007 and 2008. The first COMET centers are expected to start in autumn 2007 for a period of up to ten years.

\footnotetext{
${ }^{23}$ European Innovation Scoreboard 2005, in: http://trendchart.cordis.lu/scoreboards/scoreboard2005/executive summary.cfm. ${ }^{24}$ homepage for COMET and COMET presentation paper, in: http://www.ffg.at/content.php?cid=352, see also: BMWA and BMF (2006), Wirtschaftsbericht Österreich 2006, Wien.
} 
The R\&D SME promotion offensive offers tax concessions for contract research (see above) and improved framework conditions for venture-capital markets. In place since 2005, its aim is to increase the share of investment in private equity and venture capital. The offensive is expected to have a positive influence on R\&D activity in Austria's private business sector. The Austrian "headquarter policy" aims at keeping business enterprises with R\&D capacities in Austria, or to attract them to Austria.

The promotion of young academics measure is partly based on a new system of grants to increase "brain circulation" (including a database for grants and research funding and a mobility portal) and partly relies on grants for research in high tech facilities and in mathematics. It reorganizes funding and promotion of young academics in order to create a favourable framework with positive spill over effects on R\&D and innovation.

Attempts to create a favourable $R \& D$ infrastructure comprise the implementation of GRID structures and a focus on physics (Quantenphysik) and applied mathematics as strategic research areas. The founding of the Institute of Science and Technology Austria (ISTA) in 2006 promotes basic research in natural and technical sciences as well as national and international cooperation.

Further development of the Fachhochschulsektor until 2010 with a focus on technical and natural sciences will offer 33.000 more places for students. The new financing agreement for the universities for 2007-2009 will reallocate funding according to research activity and other performance parameters. Funding in 2007 amounts to 2064,5 million $€$, with 2083,1 million $€$ and 2 108,5 million $€$ for 2008 and 2009. An additional 500 million $€$ will be made available for general refurbishment.

Innovation-friendly public procurement guidelines are currently being set up. These guidelines will focus on using procurement as a stimulant for innovation.

\section{Effects of NPR 2005 R\&D and innovation measures on GDP and employment:}

Since the effects of investment in R\&D and innovation only become visible in the medium or long term, growth effects of NRP have to be approximated from above-mentioned OECD studies. Employment effects may then be calculated indirectly from the growth effects.

We estimate that the combined efforts in the field of R\&D and innovation - based on literature findings and an increasing share of business R\&D and innovation - will create a long term growth effect of approximately 0.1 percentage point of GDP. On the other hand, a total absence of R\&D and innovation (i.e. the development of GDP without such continuous efforts) in the coming years would result in approximately 0.45 percentage points less GDP growth. 
It is assumed that employment effects from R\&D and innovation may be limited to indirect effects as such measures primarily raise the productivity level of employees and the overall efficiency of an economy.

Note, however, that empirical estimates of the impact of R\&D on economic growth and employment vary considerably. The results presented here should be regarded as conservative approximations of potential effects. 
Figure 6: R\&D expenditure and R\& D intensity

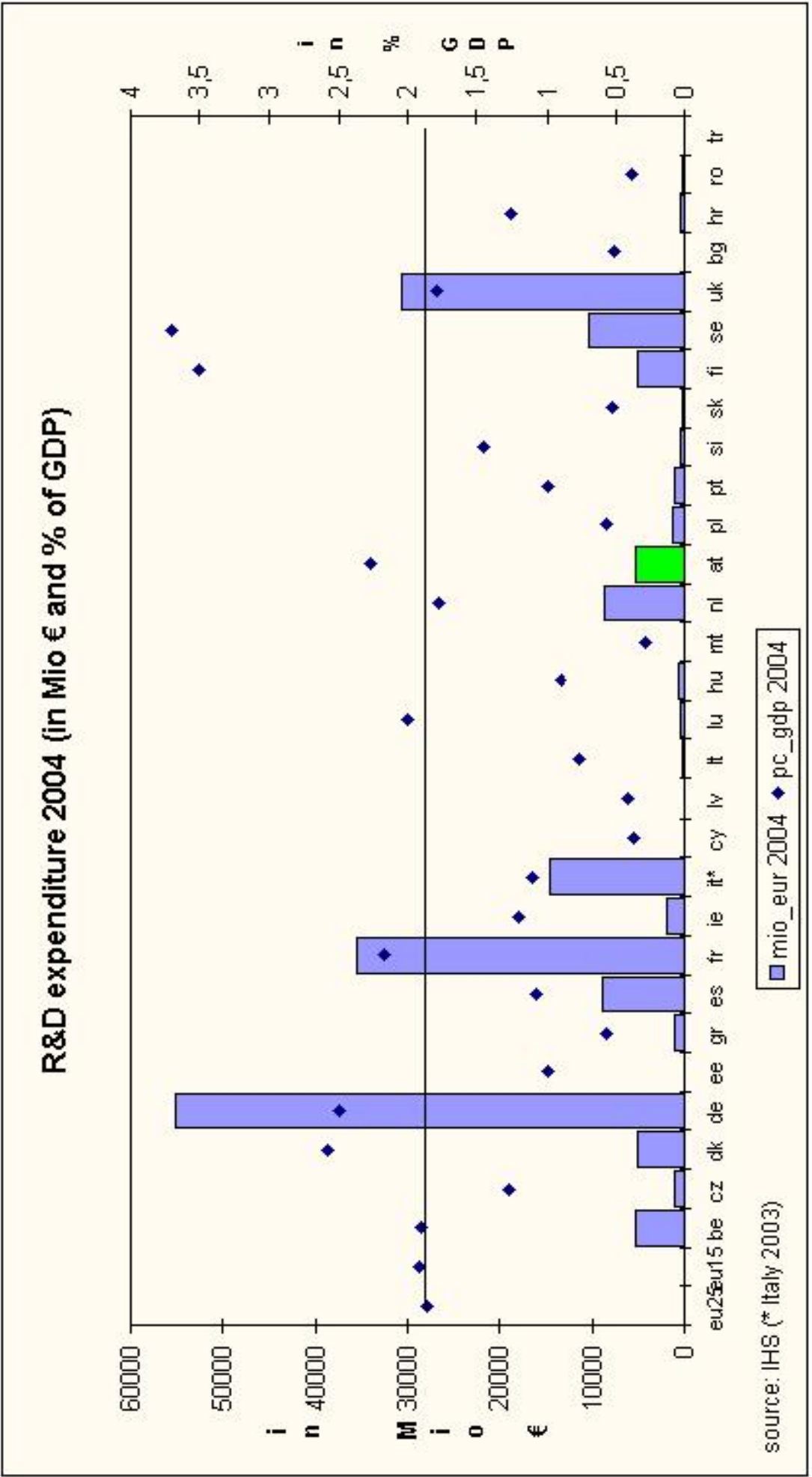

Explanation: The "dots" correspond to R\&D intensity (\% of GDP), with the line representing EU25 average; the "bars" represent R\&D expenditure (in Mio $€$ ), thereby indicating countries with larger or smaller R\&D budgets. 
Figure 7: R\&D intensity in Europe

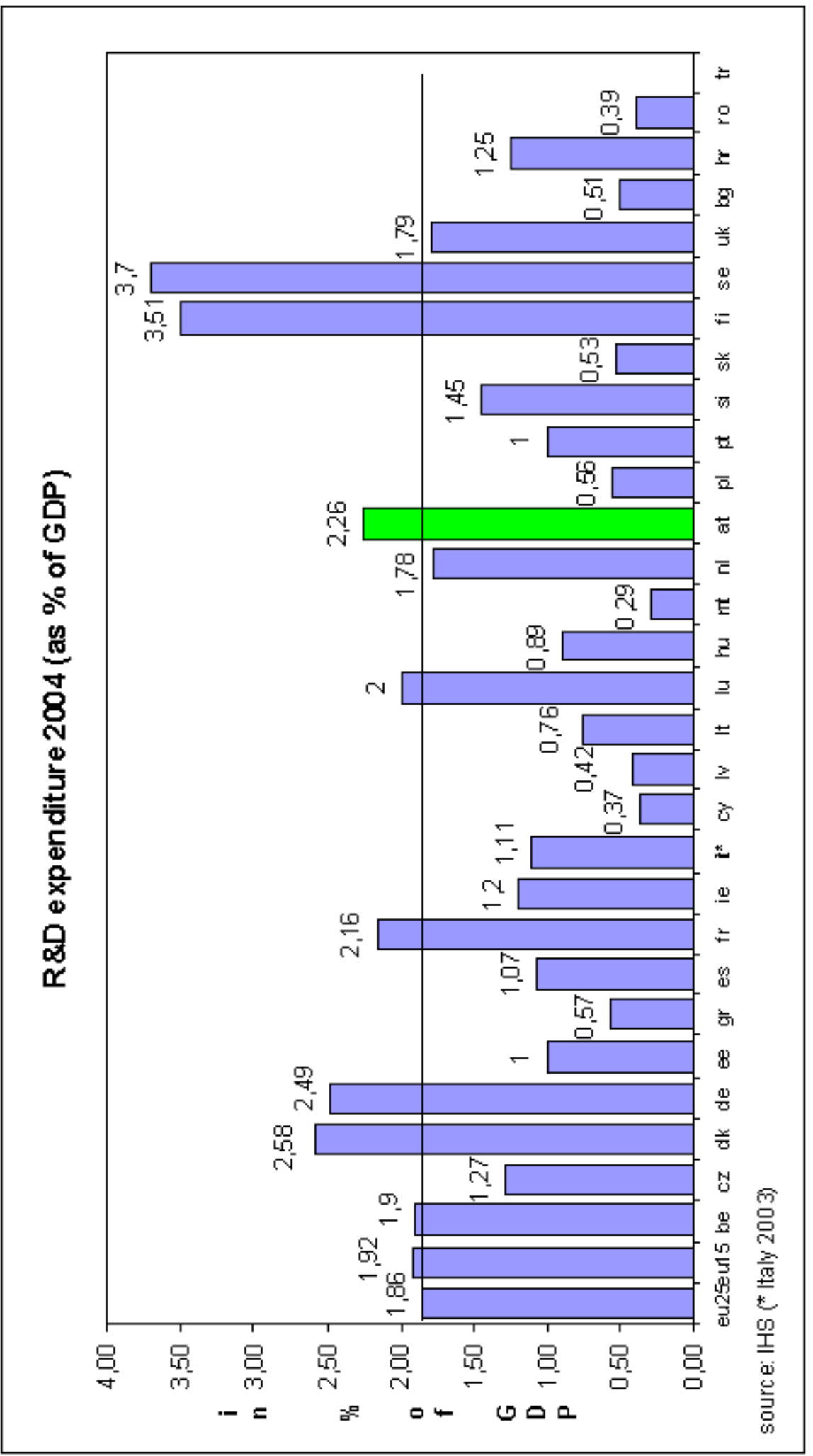


Figure 8: Development of Austrian R\&D expenditure

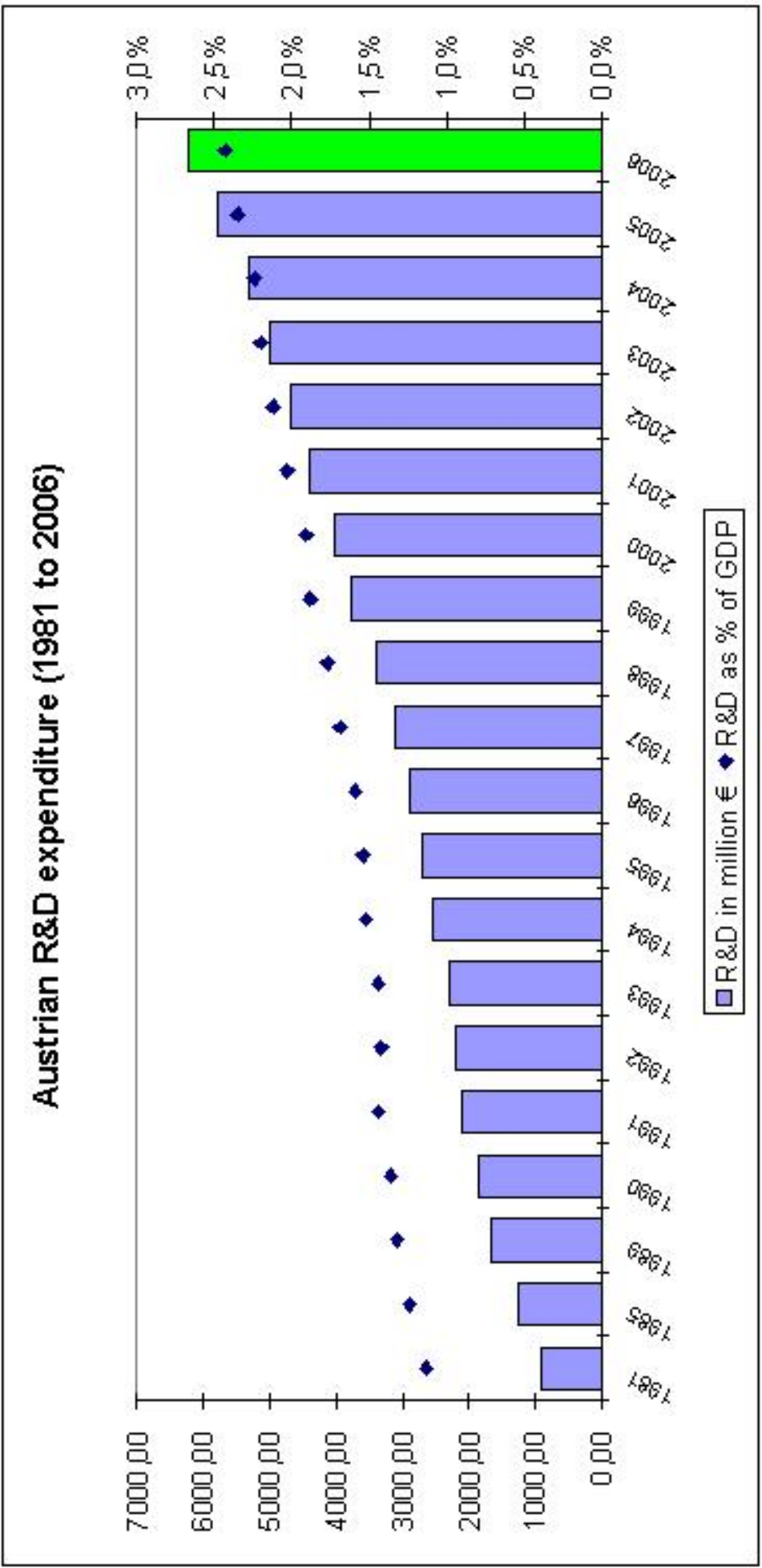

Source: IHS (based on STATISTIK AUSTIA data). 
Figure 9: Composition of R\& D expenditure in Austria (source of funds)

\section{Funding of R\&D Performed in Austria 1981, 1985, 1989, 1993 - 2006}

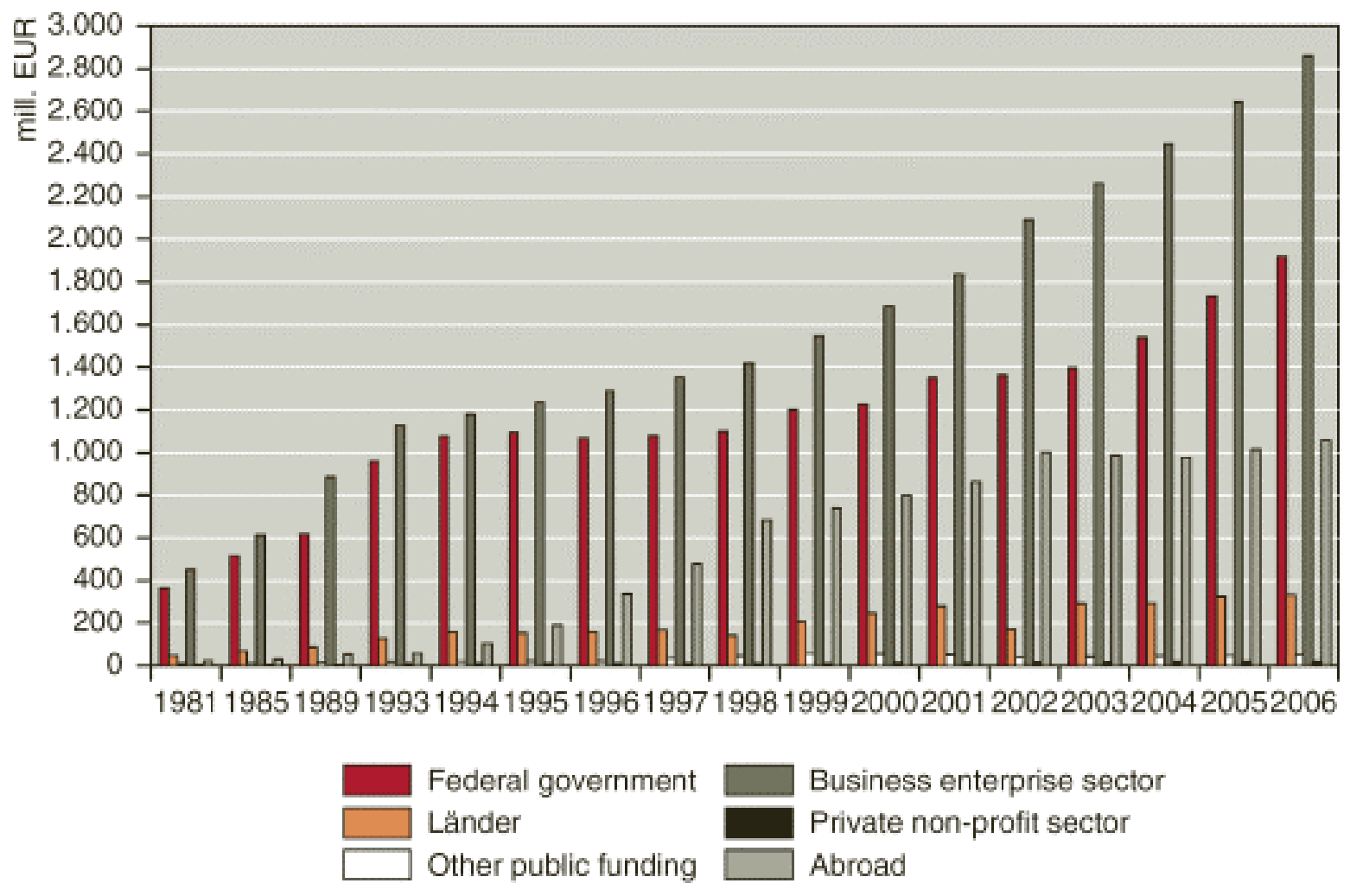

Source: STATISTIK AUSTRIA (2006). 
Table 9: Total R\&D Expenditure in the EU countries

\begin{tabular}{|c|c|c|c|}
\hline \multicolumn{4}{|c|}{ Total R\&D Expenditure (in Mio $€$ and as $\%$ of GDP) } \\
\hline & & mio_eur & pc_gdp \\
\hline & & 2004 & 2004 \\
\hline European Union (25 countries) & eu25 & & 1,86 \\
\hline European Union (15 countries) & eu15 & & 1,92 \\
\hline Belgium & be & 5464,63 & 1,90 \\
\hline Czech Republic & $\mathrm{cz}$ & 1100,09 & 1,27 \\
\hline Denmark & $\mathrm{dk}$ & 5083,43 & 2,58 \\
\hline Germany (including ex-GDR from 1991) & de & 55100,00 & 2,49 \\
\hline Estonia & ee & 83,00 & 1,00 \\
\hline Greece & gr & 967,00 & 0,57 \\
\hline Spain & es & 8945,76 & 1,07 \\
\hline France & $\mathrm{fr}$ & 35648,10 & 2,16 \\
\hline Ireland & ie & 1780,40 & 1,20 \\
\hline Italy* & it* & 14769,00 & 1,11 \\
\hline Cyprus & cy & 46,40 & 0,37 \\
\hline Latvia & IV & 46,71 & 0,42 \\
\hline Lithuania & It & 136,99 & 0,76 \\
\hline Luxembourg & Iu & 450,00 & 2,00 \\
\hline Hungary & hu & 721,31 & 0,89 \\
\hline Malta & $\mathrm{mt}$ & 12,47 & 0,29 \\
\hline Netherlands & $\mathrm{nl}$ & 8721,00 & 1,78 \\
\hline Austria & at & 5346,08 & 2,26 \\
\hline Poland & $\mathrm{pl}$ & 1138,86 & 0,56 \\
\hline Portugal & $\mathrm{pt}$ & 1059,00 & 1,00 \\
\hline Slovenia & si & 379,45 & 1,45 \\
\hline Slovakia & sk & 174,03 & 0,53 \\
\hline Finland & $\mathrm{fi}$ & 5253,42 & 3,51 \\
\hline Sweden & se & 10426,12 & 3,70 \\
\hline United Kingdom & uk & 30643,88 & 1,79 \\
\hline Bulgaria & bg & 99,49 & 0,51 \\
\hline Croatia & $\mathrm{hr}$ & 344,95 & 1,25 \\
\hline Romania & ro & 235,28 & 0,39 \\
\hline Turkey & $\operatorname{tr}$ & & \\
\hline
\end{tabular}

source: EUROSTAT (extracted: 18.10.2006) ～* values 2003

Note that due to the use and update of estimates data in Table 10 does not exactly match data in Table 9. 
Table 10: Development of R\&D expenditure in Austria

\begin{tabular}{|c|c|c|}
\hline \multicolumn{3}{|c|}{ Gross domestic expenditure on R\&D from 1981 to } \\
2006 in Austria \\
\hline & Gross domestic expenditure on R\&D \\
\cline { 2 - 3 } & R\&D in million $€$ & R\&D as \% of GDP \\
\hline 1981 & 896,14 & $1,13 \%$ \\
\hline 1985 & 1248,68 & $1,24 \%$ \\
\hline 1989 & 1669,07 & $1,32 \%$ \\
\hline 1990 & 1857,58 & $1,36 \%$ \\
\hline 1991 & 2104,78 & $1,44 \%$ \\
\hline 1992 & 2203,55 & $1,42 \%$ \\
\hline 1993 & 2303,31 & $1,44 \%$ \\
\hline 1994 & 2550,73 & $1,52 \%$ \\
\hline 1995 & 2701,68 & $1,54 \%$ \\
\hline 1996 & 2885,55 & $1,59 \%$ \\
\hline 1997 & 3123,21 & $1,69 \%$ \\
\hline 1998 & 3399,83 & $1,77 \%$ \\
\hline 1999 & 3761,80 & $1,88 \%$ \\
\hline 2000 & 4028,67 & $1,91 \%$ \\
\hline 2001 & 4393,09 & $2,03 \%$ \\
\hline 2002 & 4684,31 & $2,12 \%$ \\
\hline 2003 & 4997,75 & $2,20 \%$ \\
\hline 2004 & 5317,91 & $2,24 \%$ \\
\hline 2005 & 5784,15 & $2,35 \%$ \\
\hline 2006 & 6240,30 & $\mathbf{2 , 4 3} \%$ \\
\hline
\end{tabular}

source: STATISTICS AUSTRIA (2006)

Note that due to the use and update of estimates data in Table 10 does not exactly match data in Table 9.

\subsection{Infrastructure Initiative}

\section{Summary}

Endogenous growth theories suggest that infrastructure is an engine of growth. Better (transport) infrastructure reduces the costs of enterprises and leads to a more efficient allocation of resources. The quantitative impact is empirically well researched. Austria has a very well developed infrastructure stock - the accession of the 10 new Member States gives rise to the need for further investment. Austria plans to spend 45.1 billion $€$ on transport infrastructure (29.9 bio. on rail, 15 bio. $€$ on road and 0.2 bio. $€$ on waterway projects).

As only investment figures for traffic infrastructure could be obtained, we estimated the effect of the planned traffic infrastructure investment. The results indicate an upward shift in GDP by about 1.5 percent in the long run. 
Figure 10: Effects of NRP on Economic Interactions - Infrastructure Initiative

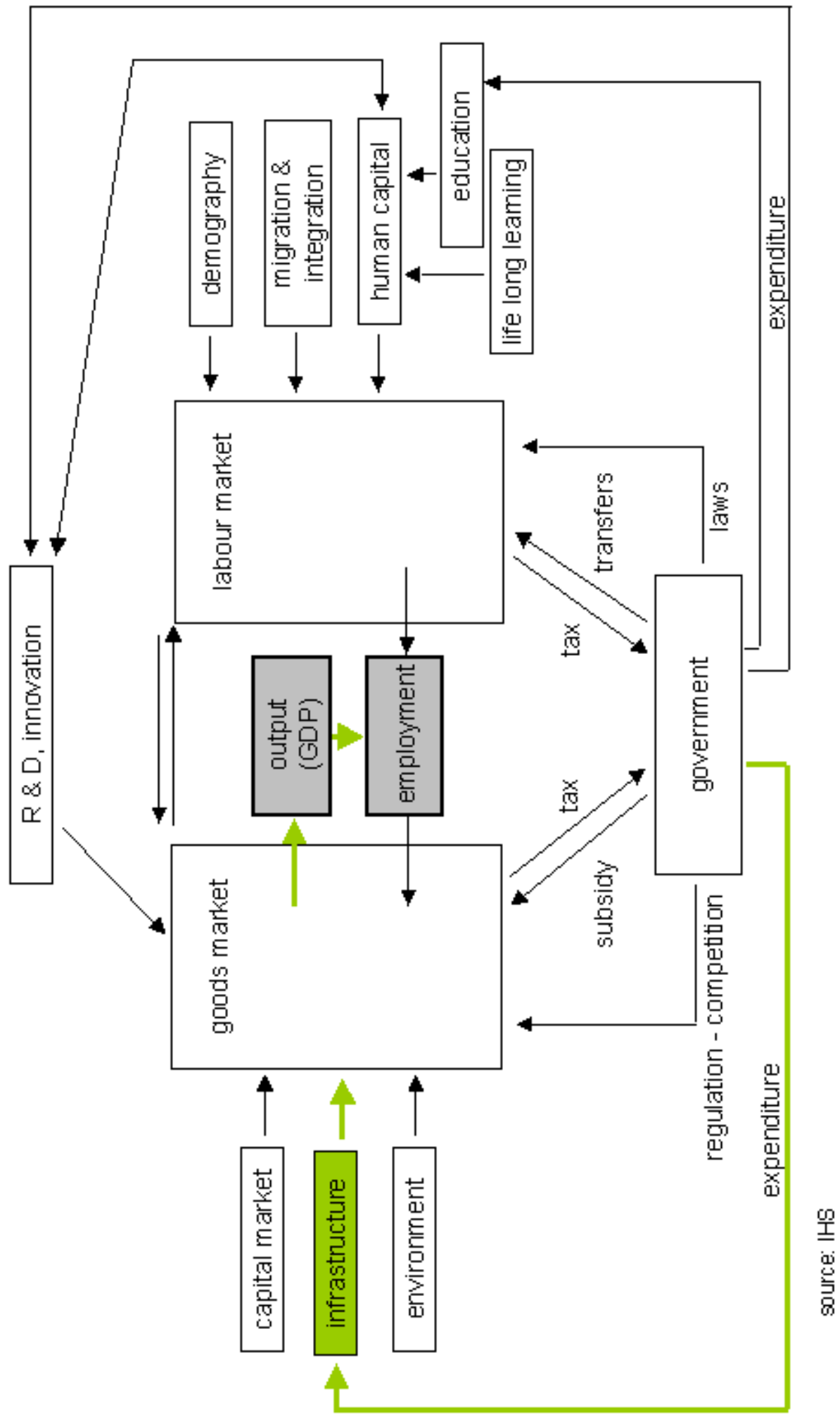




\section{Expected effects of the Infrastructure Initiative (to expand, improve and link up European infrastructures and complete priority cross-border projects) on economic growth and employment}

Infrastructure, in general, is considered to be of great importance as an engine for growth according to endogenous growth theory. The OECD acknowledges this fact by calling infrastructure a factor directly related to economic growth. ${ }^{25}$

For transportation infrastructure there is a large number of studies indicating a positive growth effect of infrastructure spending. The reason for this is that an improved transport infrastructure will reduce transport costs and will divert economic resources from transportation to more productive uses. Thereby overall productivity increases which has a positive effect on economic growth. Through reducing costs and strengthening productivity, transport infrastructure will have a positive effect on the whole country as an attractive location for enterprises. These positive effects are well documented in the literature. The aggregate effects of public infrastructure on economic growth vary between 0.08 and $0.65{ }^{26}$

Apart from measures concerning traffic infrastructure Austria initiated an amendment to the law intended to promote the use of renewable energy resources. ${ }^{27}$ The goals of this measure are to further promote the production of renewable energy (fostering the competitiveness of renewable energy, optimised use of promotion funds, fostering the development of low-cost energy production facilities) and the creation of a single body for the central handling of the promotion (OeMAG). The expected effects are fostering research and development in the area of alternative energy and an improvement of the medium- to long-term growth prospects of Austrian enterprises for which incentives were created to develop and produce international competitive components for the use of renewable energy. ${ }^{28}$ This increase in competitiveness secures economic growth and employment.

A second measure related to energy was the change in tariff regulation of electricity prices. The original system of cost-based regulation was modified to a regulation regime that better takes incentives into account. ${ }^{29}$ From an economic perspective an incentive based regulation will lead to more efficient pricing and will thus reduce deadweight losses as compared to the other type of regulation. This will lead to a better allocation of resources and will thereby induce employment and growth effects.

\footnotetext{
${ }^{25}$ OECD (2003), The sources of economic growth in OECD countries, Paris.

${ }^{26}$ Romp, W. and de Haan, J. (2005), Public capital and economic growth: a critical survey, EIB papers vol. 10 (1), pp. $40-42$.

${ }^{27}$ Ökostromgesetz-Novelle 2006, BGBI I Nr 105/2006.

${ }^{28}$ Bodenhöfer, H. J. et al. (2004): Bewertung der volkswirtschaftlichen Auswirkungen der Unterstützung von Ökostrom in Österreich. Forschungsbericht IHS Kärnten.

${ }^{29}$ Systemnutzungstarife-Verordnung (SNT-VO 2006).
} 


\section{Current Situation}

For transport infrastructure development, Austria plans to spend a total of 45.1 billion $€$ on transport infrastructure, whereby approximately 29.9 billion $€$ will be spent on railway projects, 15 billion $€$ on roads and 0.2 billion $€$ on waterway infrastructure. The main part of these funds is used to either improve the connectivity to the new accession states and/or Trans European Networks (Brenner Basistunnel, railway link Vienna-Bratislava etc.). ${ }^{30}$

In contrast to the original plan new priorities have been set. These include the faster realization of Brenner Basistunnel, which was originally scheduled for 2021 and is now being considered a top priority as well as measures to improve infrastructure along the TEN Priority Axis 17 and the Baltic-Adriatic corridor. These railroad related measures can be considered to have a substantial impact on the Austrian growth potential since they improve the integration of Austrian regions into the European economy. They also foster the integration of Austrian regions with those of the new EU Member States bordering Austria.

With respect to road infrastructure the construction of the motorway between Bruckneudorf and Kittsee has to be mentioned as a very important project since it will remove a notorious bottleneck between Vienna and Bratislava.

For the period of 2006-2008 a budget of 8.9 billion $€$ is scheduled for infrastructure investment. Most of this money is dedicated to the construction of new infrastructure projects. Out of the 8.9 billion $€, 4.2$ billion $€$ are scheduled for railway projects while 4.8 billion $€$ are dedicated to road infrastructure.

As regards renewable energy production Austria occupied the $6^{\text {th }}$ rank within the OECD in terms of the contribution of renewable energy to total energy supply. ${ }^{31}$

As only investment figures for traffic infrastructure could be obtained we estimated the effect the planned traffic infrastructure investment based on elasticities taken from the literature. The results indicate a level shift of GDP by about 1.5 percent over the long run.

\footnotetext{
${ }^{30}$ BMVIT (2002), Generalverkehrsplan Österreich 2002, Verkehrspolitische Grundsätze und Infrastrukturprogramm, Januar 2002.

${ }^{31}$ OECD Factbook 2006: Economic, Environmental and Social Statistics. OECD Paris.
} 
$54-$ Evaluation of NRP/I H S

Figure 11: Expected and realised Traffic Infrastructure Investment

\section{Expected and realised Traffic Infrastructure} Investment

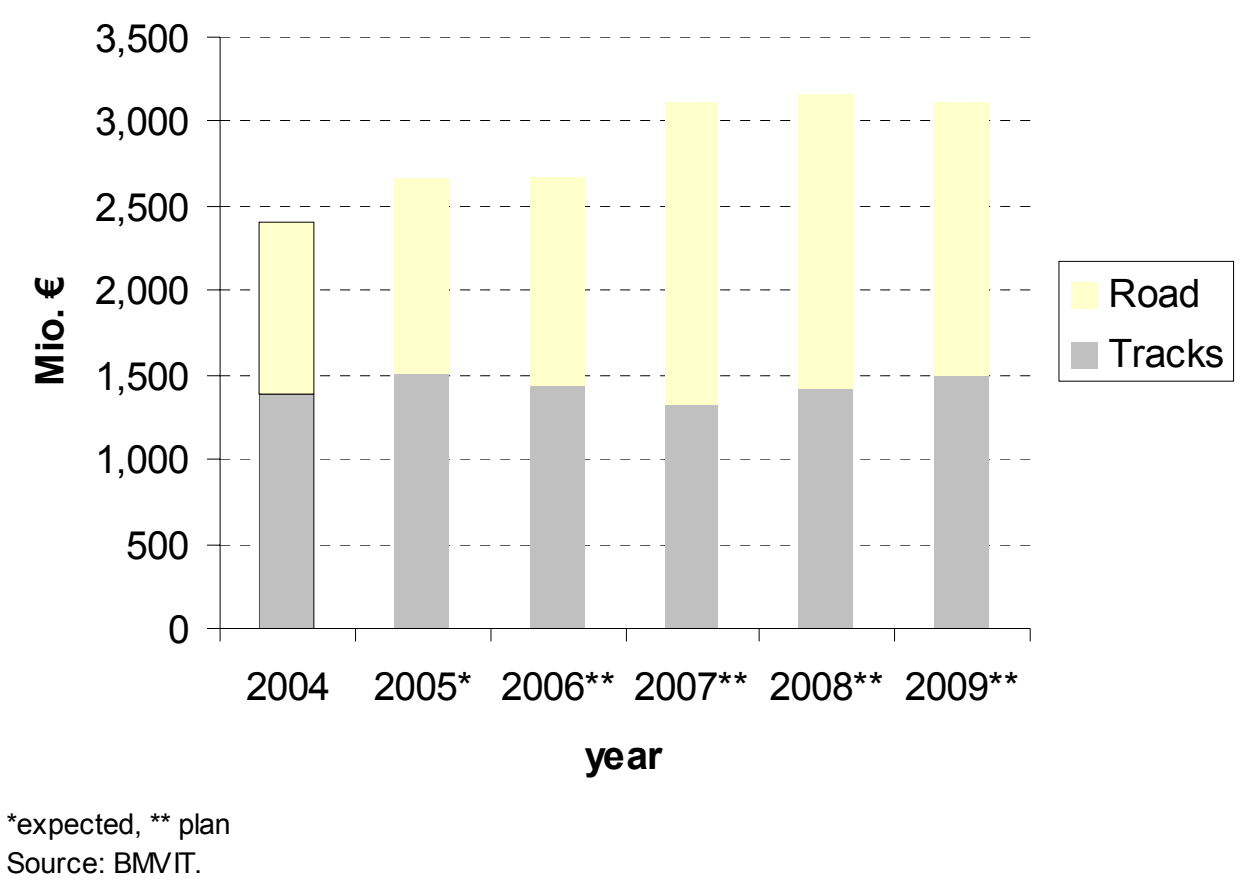


Table 11: Contribution of renewables to energy supply (as a percentage of total primary energy supply)

\begin{tabular}{|c|c|c|c|c|}
\hline & \multicolumn{2}{|c|}{ average 00/04 } & \multicolumn{2}{|l|}{ share } \\
\hline & share & rank & 2004 & rank 2004 \\
\hline Iceland & 71.94 & 1 & 70.5 & 1 \\
\hline Norw ay & 45.1 & 2 & 40.5 & 2 \\
\hline New Zealand & 28.32 & 3 & 30.1 & 3 \\
\hline Sweden & 27.72 & 4 & 25.5 & 4 \\
\hline Finland & 23.06 & 5 & 23.8 & 5 \\
\hline Austria & 22.28 & 6 & 22.3 & 6 \\
\hline Sw izerand & 18.1 & 7 & 17.4 & 7 \\
\hline Canada & 16.18 & 8 & 15.7 & 8 \\
\hline D enm alk & 12.86 & 11 & 15.1 & 9 \\
\hline Portugal & 1528 & 9 & 14.5 & 10 \\
\hline Turkey & 13.12 & 10 & 132 & 11 \\
\hline M exico & 9.98 & 12 & 9.9 & 12 \\
\hline Spain & 6.18 & 14 & 6.4 & 13 \\
\hline Taly & 6.14 & 15 & 6.4 & 14 \\
\hline France & 6.5 & 13 & 6.3 & 15 \\
\hline EU2 5 & 5.975 & 17 & 6.1 & 16 \\
\hline OECD total & 5.98 & 16 & 6 & 17 \\
\hline Australia & 5.88 & 18 & 5.4 & 18 \\
\hline Poland & 522 & 19 & 5.4 & 19 \\
\hline G reece & 5.1 & 20 & 53 & 20 \\
\hline United States & 4.48 & 21 & 45 & 21 \\
\hline G erm any & 3.7 & 23 & 4.5 & 22 \\
\hline S bvak R epublic & 4.12 & 22 & 3.9 & 23 \\
\hline Hungary & 2.96 & 25 & 3.7 & 24 \\
\hline Japan & 3.48 & 24 & 3.5 & 25 \\
\hline C zech R epublic & 2.54 & 26 & 32 & 26 \\
\hline Netheriands & 2.54 & 27 & 2.8 & 27 \\
\hline Belgium & 1.84 & 28 & 23 & 28 \\
\hline Ireland & 1.78 & 29 & 1.9 & 29 \\
\hline Luxem bourg & 1.42 & 30 & 1.5 & 30 \\
\hline United Kingdom & 126 & 31 & 1.4 & 31 \\
\hline
\end{tabular}

Source: OECD Fact book 2006 - Economic, Environmental and Social Statistics, IHS calculations. 


\subsection{Forster Competition and SME Initiative}

\section{Summary}

High investment in ICT has contributed to the surge in productivity growth in the United States since 1995. Investment into and effective use of ICT is an integral part of the Lisbon Agenda. The impacts of ICT on productivity are achieved in three ways - by raising capital stock (capital deepening), by raising total-factor productivity through growth in high tech ICT sectors and spill over effects to other sectors. Measures in the Austrian NRP are in line with the Lisbon Agenda and are seen as adequate. It is, however, difficult to quantify the exact magnitude of the initiatives in this field, as a number of studies have shown that ICT interacts with various other economic variables. The broadband initiative in combination with the successful implementation of planned e-government measures is expected to raise Austrian total factor productivity (TFP) in the long run. Eventually, an increase in economic growth can be expected, which could also positively affect employment demand. This last effect, however, is ambiguous, as increasing productivity is not always associated with an increase in labour demand, depending on whether the productivity increase is driven by rationalization or not.

With respect to market capitalisation and domestic credit to the private sector, Austria ranks below EU-15 average; the performance of the Austrian stock market, however, is in the top third of EU-15. Initiatives in the field of financial markets are embedded in coherent strategies of the European Union; the implementation of measures has so far been in time. The actions listed in the NRP, in particular FSAP and SEPA, constitute an integral part of EUwide programmes to fasten financial market integration. Since the impact of the actions set in 2006 will be realized only in the long term (and probably not be distinguishable from actions in the same programme taken in 2005 and 2007), we can only give an extremely rough estimate based on empirical studies reviewed above. Provided all FSAP and SEPA actions are successfully implemented, long-term potential economic growth may be increased marginally.

The adverse effects of collusive behaviour of firms are theoretically and empirically extensively documented. Current activities bring Austrian law in line with European Community guidelines and administrative procedures have been simplified. Changes to competition law are not expected to bring any direct benefits in terms of employment and economic growth. Yet, a better functioning of competition law is expected to exert indirect positive effects.

The increased openness of the economy has a positive impact on economic growth and international trade has an economically significant and statistically robust positive effect on productivity. There also are significantly positive aggregate scale effects. The external sector of the Austrian economy has had an excellent performance in recent years: on average 
exports have increased by $3.1 \%$ in real terms (GDP growth amounted to $2.1 \%$ ). In the current and next year, foreign trade will remain a major source of growth in the Austrian economy. The Institute for Advanced Studies (IHS) expects that exports will contribute, on a yearly average, 3.3 percentage points to the GDP growth rate. Due to the efforts of the initiative "go-international", which supports Austrian firms in improving international competitiveness, the export of services - at present still quite small - might gain importance.

Due to the economic structure of the European Union targeted measures for SMEs are essential. Issues to be addressed in this context are the costs of financing, taxation of SMEs and the lowering of administrative barriers. Important Austrian measures are the SME initiative 2006, ongoing programmes undertaken by AWS and the implementation of the standard cost model to reduce the administrative burden. A model simulation for the prospective impact of reduced regulation costs of businesses suggests that real GDP may be increased by $3 / 4$ percent and additional 12.000 jobs may be created, if the targets of the NRP are met. Austrian initiatives promise positive effects in accordance with the European Union strategy. The focused actions seem to correspond well to the perceived problems of the Austrian firms and can therefore be regarded as adequate. 
Figure 12: Effects of NRP on Economic Interactions - Foster Competition and SME initiative

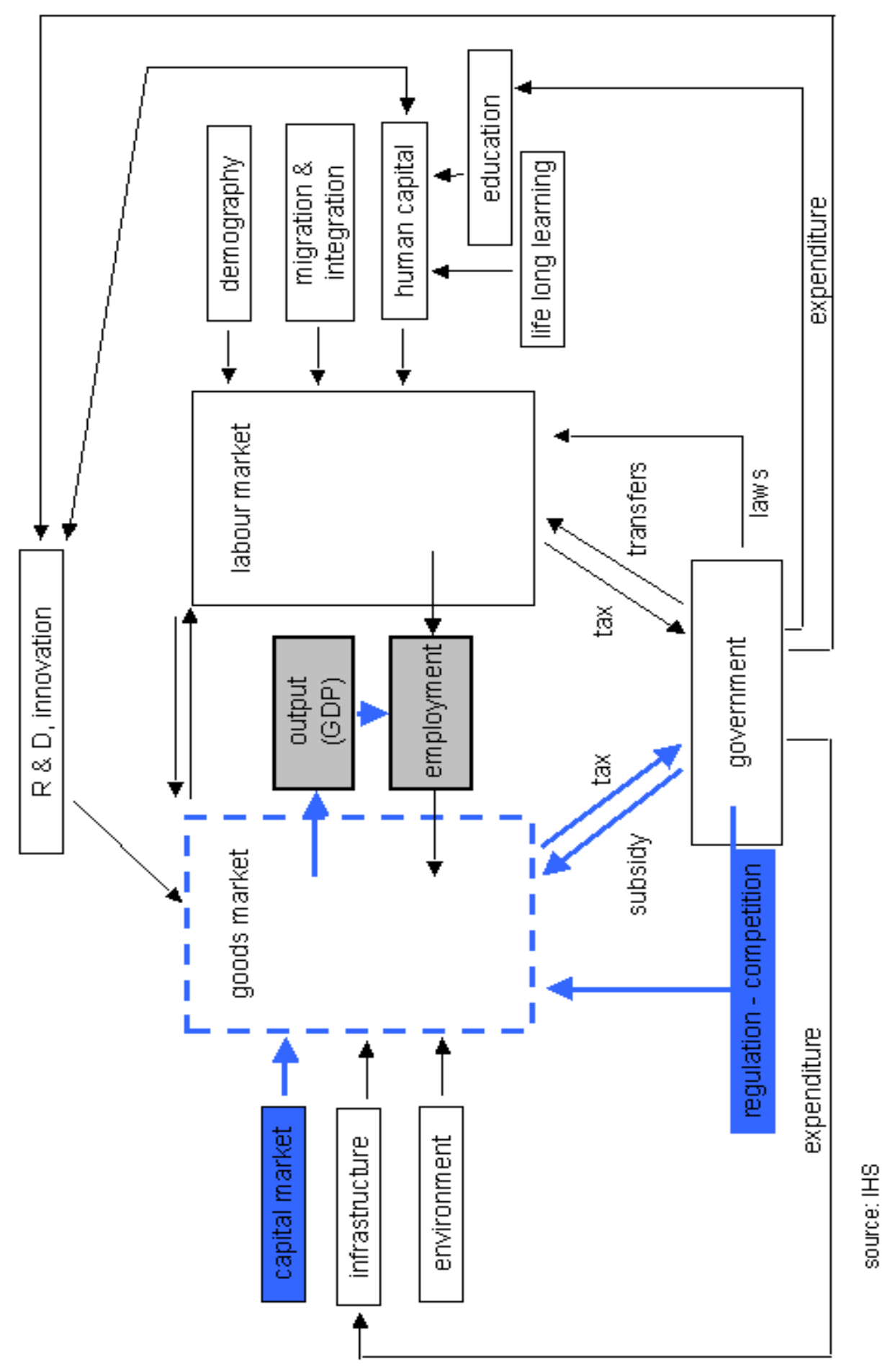




\section{Information and Communication Technology (ICT)}

\section{Expected Effects of ICT on growth and employment}

It has become orthodox ${ }^{32}$ in growth theory that the surge in productivity growth in the USA since the mid-1990s - absent in the EU - has been due to high overall investment in, and effective use of, ICT, especially in the services sector. ${ }^{33,34,35}$ Indeed the phenomenon of ICT as a general purpose technology, similar in effect to the steam engine or the electric motor, has been referred to by US Federal Reserve Chair Ben Bernanke. ${ }^{36}$

Long-term growth of GDP depends crucially on the rate of productivity growth in the economy. ICT affects economic growth through investment in ICT, its production, and also the productive uses to which it is put. An IHS study (cf. footnote 3) showed the extent to which investment in ICT is important by adding to capital deepening (capital made available per worked hour), and, in successful implementations, to total factor productivity.

Figure 13 illustrates that both of these effects were found in the USA in the large market services sectors, wholesale services, retail services, and (tele)-communications for the period 1995-2001, ${ }^{37}$ but to a much lesser degree in the EU (represented by four of the five largest EU economies, EU4, ${ }^{38}$, with the exception of a strong performance in the EU's ICTproducing services sector itself. In the chart, labour productivity is shown on the left column, and its breakdown into contributions from the quality of labour, ICT-capital, non-ICT capital, and TFP is shown in the other bars to the right. Although the relative contribution of ICT to productivity through capital deepening in these sectors (plus the financial services sector) was structurally equivalent, at $31 \%$, the overall (annualised) productivity growth in these four sectors was $6.6 \%$ in USA, nearly two and a half times that in the EU $(2.8 \%)$ in the corresponding period. In particular the large gains in TFP, often seen as the real driver of growth within the economy, are considered to be induced by ICT, representing both the upward technological shift and sectoral efficiency improvements resulting from its effective deployment.

\footnotetext{
${ }^{32}$ That this was not always so is neatly illustrated by the contemporary statement attributed in 1987 to Nobel Prize Winner Robert Solow that "'computers are everywhere except in the productivity statistics", recalled by B. Bernanke ${ }^{33}$ O'Mahony, M. and van Ark, B. (ed.) (2003): EU productivity and competitiveness: An industry perspective - Can Europe resume the catching-up process?, European Commission.

${ }^{34}$ Felderer, B., Graf, N., Paterson, I., Polasek, W., Schwarzbauer, W., Sellner, R. (2005): The European Services Market in the Context of the Lisbon Agenda - Productivity and Employment in European Services with high Intensity of Information and Communications Technology (ICT) - Study commissioned by the Federal Chancellery of Austria.

${ }^{35}$ See, for example, Dale Jorgenson on "Information Technology and the World Economy", and other contributions to the "Determinants of Productivity Growth," Special Issue of the German Economic Review (forthcoming).

${ }^{36}$ Address delivered by Ben S. Bernanke at Massachusetts Institute of Technology (MIT), June 9, 2006.

${ }^{37} 2001$ was the last year of available data at the time of the study.

${ }^{38}$ Data for only Germany, France, the UK and the Netherlands was available in the GGDC Growth Accounting database.
} 
Lower absolute levels of ICT capital can be contributory to less significant spill over effects and lower network externality gains from use of ICT, as these are likely to be dependent on a sufficiently high level of users of the new technologies. ${ }^{9}$

Figure 13: Growth Rate Contributions to ICT-Intensive Services (Communications, Wholesale, Retail) by Growth Accounting, EU4 and USA, 1995-2001
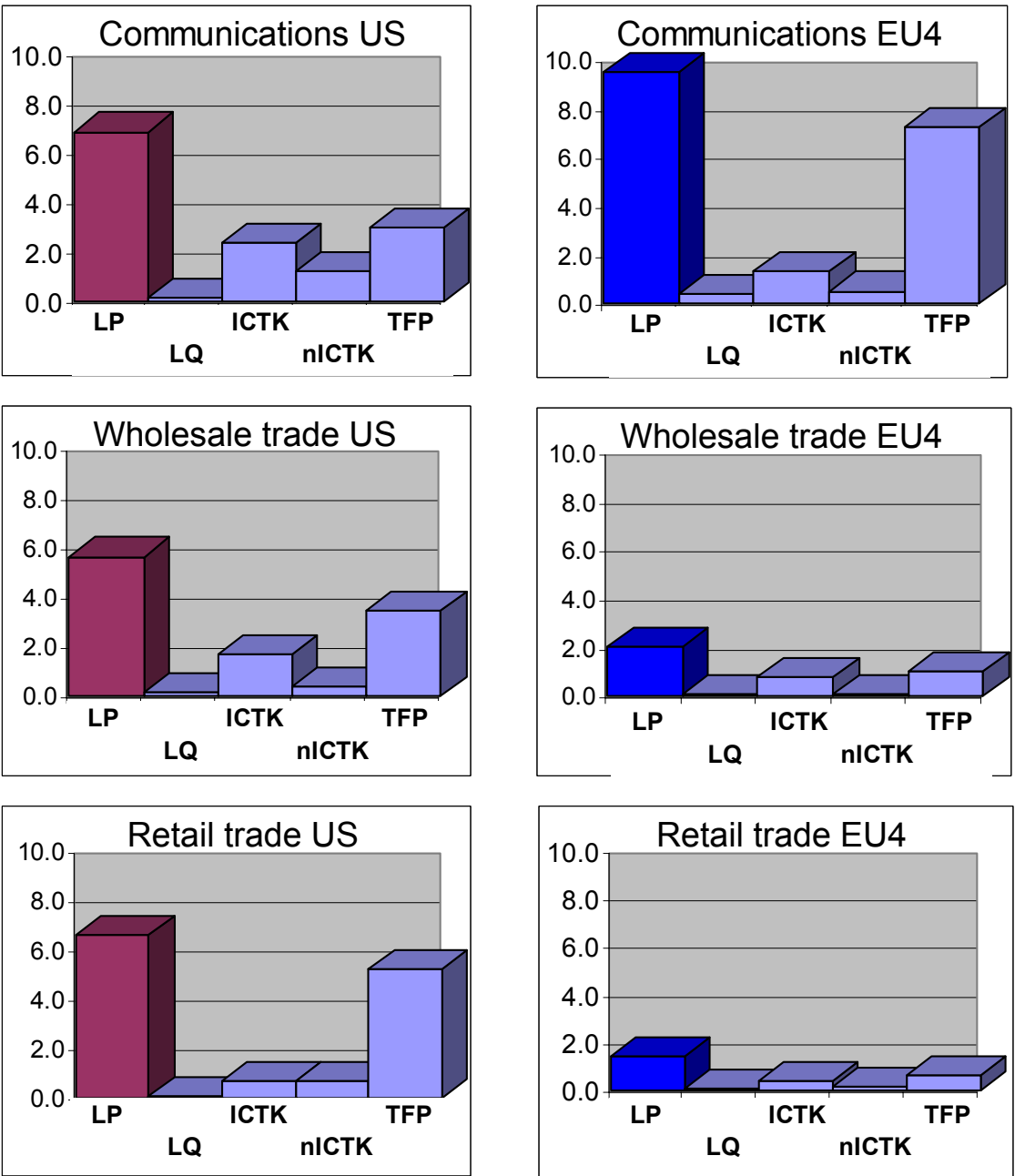

LP: Labour Hours Productivity; LQ: Labour Quality; ICTK: ICT_Capital; nICTK: non-ICT Capital; TFP: Total Factor Productivity Sources GGDC; IHS calculations

The relationship between ICT investment as a percent of GDP and average ICT capital contributions to GDP growth has been illustrated in a recent EU Commission staff paper ${ }^{39}$ based on work of GGDC (Groningen Growth and Development Centre). The diagram shown in Figure 14 shows that the relation is positive for the EU15 countries and USA in the period

\footnotetext{
${ }^{39}$ Effects of ICT capital on economic growth, EU Commission Staff Paper, 30 June 2006, Brussels.
} 
1995-2004. This relationship underpins the argument ${ }^{40}$ that differences between countries in the impact of ICT on economic growth can be attributed to either differences in investment levels or investment growth. Consistently higher investment in ICT have given rise to ICT capital stocks twice as large in the USA as compared to the EU, a fact which, it is argued, results in the labour force being equipped with less ICT capital, not only quantitatively, but also qualitatively, since such investments often introduce new technologies and induce innovation in the production process.

Figure 14: ICT capital investments vs. ICT capital contributions to GDP growth, averaged from 1995-2004. (From EU Commission Staff Paper)

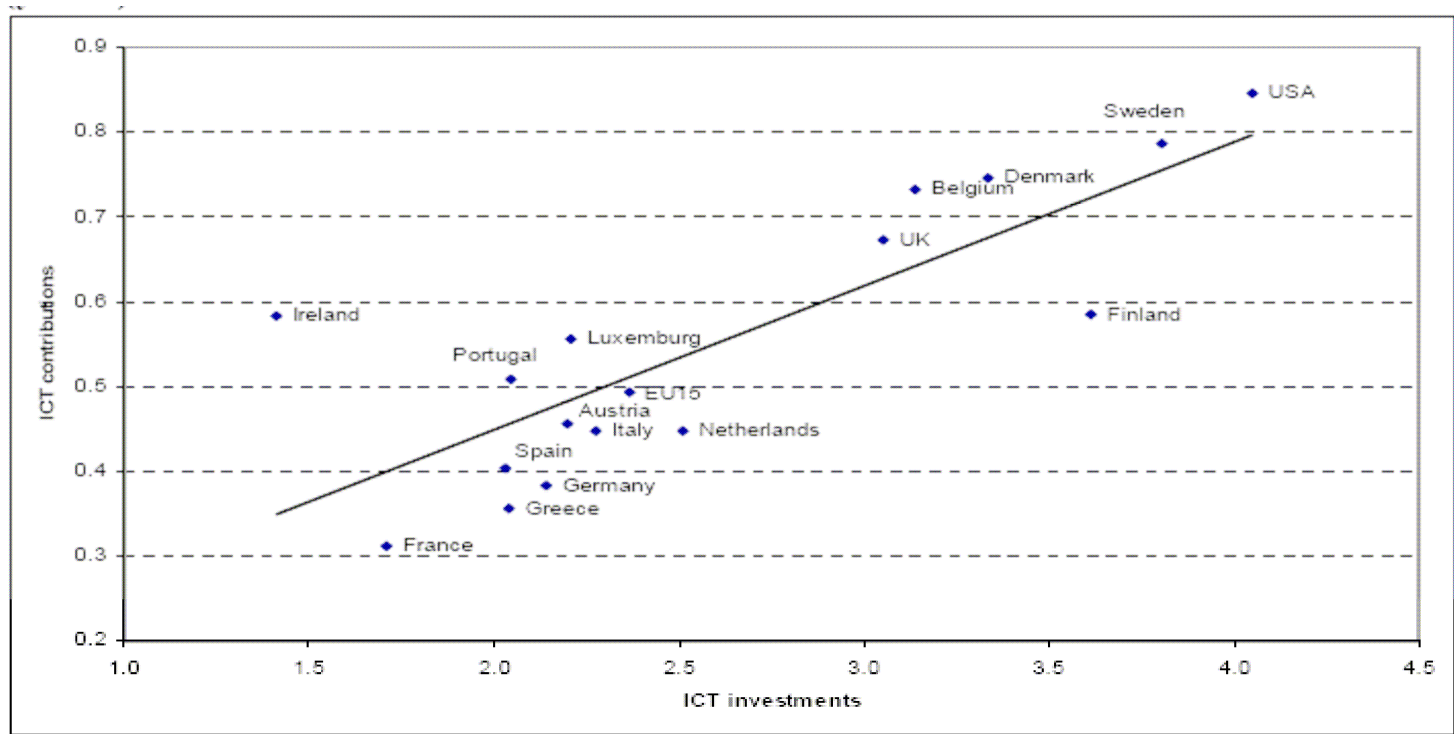

Source: Marcel P. Timmer, Gerard Ypma and Bart van Ark (2003), IT in the European Union: Driving Productivity Divergence?, GGDC Research Memorandum GD-67 (October 2003), University of Groningen, Appendix Tables, updated June 2005 and own calculations

In a wider perspective it is also the view taken by the OECD ${ }^{41}$ that ICT has continued to impact on performance since 2000 despite the turndown associated with the dot.com bust. There are wide differences in the diffusion of ICT technologies, with diffusion widest in USA Australia, Canada, New Zealand, Nordic countries and the Netherlands. Of increasing ongoing importance are b-c e-commerce, and broadband telecommunications. The impacts of ICT on productivity are achieved in three ways - by raising capital stock (capital deepening), by raising total-factor productivity (TFP) through growth in high tech ICT producing countries (Finland, Ireland and Korea), and by raising TFP through efficiency effects, network effects and spillovers. The OECD also points out that for firm-level

\footnotetext{
${ }^{40}$ OECD (2003): The Sources of Economic Growth in OECD Countries. Paris.

${ }^{41}$ OECD (2003): ICT and Economic Growth. Evidence from OECD Countries, Industries and Firms. Paris.
} 
investments ${ }^{42}$ in ICT to carry through to whole economy effects it is equally necessary that complementary factors are in place, such as lower prices of equipment and software, the existence of adequately qualified human capital, the readiness to implement organisational changes, all within a competitive economic environment.

The economic effects of promoting e-government have already been considered in the literature. One positive effect of e-government promotion is that public sector organisations will be induced to pursue interactive communication with their "customers". In the absence of ICT this is not possible and public sector organisations are not confronted by competitive pressure from the market, as are private firms. The introduction and enforcement of egovernment will create a "quasi-market for public services" in which pressures for public sector organisation will be forced to improve their productivity. ${ }^{43}$ These forces will help to improve public sector productivity and thus increase the overall productivity of the economy. The magnitude of overall effects has been shown to depend on the diffusion of ICT. ${ }^{44}$

\section{Current Situation and Effects of NRP measures}

In $200547 \%$ of all Austrians had internet access at home (10 ${ }^{\text {th }}$ in rank of EU25), 11.6 had broadband internet access (EU-rank 9). E-commerce in 2005 was at about $1 \%$ of all transactions, which implies EU-rank 15. For these three indicators the actual level achieved is generally below the EU average.

E-government initiatives in the commercial area have met success up to 2005. For full electronic case handling by enterprises and for obtaining forms electronically ${ }^{45}$ Austria occupied rank 4 and 6 with shares of 36 and $69 \%$ respectively. All indicators with respect to e-government were well above EU-15 average. In $200512 \%$ of all individuals in Austria used the internet to fill out forms for government authorities (EU-rank 6), $25 \%$ for obtaining information (EU-rank 8) and $11 \%$ for downloading official forms (EU-rank 15). A recent study asserts that "Austria has since [2003] experienced a constant growth [of public e-services] to become Europe's leading country."

\footnotetext{
${ }^{42}$ OECD (2004): The Economic Impact of ICT - Measurement, Evidence and Implications. Paris.

${ }^{43}$ Soete, L. and Weehuizen, R. (2003), The economics of e-Government. A bird's eye view, International Journal of Communications Law and Policy (IJCLP), Issue 8, Winter 2004, http://www.ijclp.org/8 2004/index.html.

${ }^{44}$ eGovernment economics project (eGEP). Project for the European Commission, DG Information Society and Media. 2006. http://217.59.60.50/eGEP/Static/E Description.asp (13.11.2006).

${ }^{45}$ All enterprises without financial sector (10 employed persons or more).

${ }^{46}$ Capgemini, June 2006,Online Availability of Public Services: How Is Europe Progressing? - Web Based Survey on Electronic Public Services.
} 
Table 12 shows the main measures of the Austrian Government concerning the Integrated Guideline 9 and gives a brief overview on the status and likely economic effects of these measures. The broadband initiative in combination with the successful implementation of planned e-government measures is expected to raise Austrian TFP in the long run. Eventually an increase in economic growth can be expected, which could also positively affect employment demand. This last effect is however ambiguous, as increasing productivity is not always associated with an increase in labour demand, depending on whether the productivity increase is driven by rationalization or not. ${ }^{47} \mathrm{~A}$ recent IHS study ${ }^{48}$ for the European services sector draws attention to the importance of labour market regulations as another factor determining labour demand and subsequent employment effects.

E-government initiatives aimed at raising public service productivity is expected to lower costs for individuals and companies in an economy. By the cost reduction companies operating in Austria will benefit from a competitive advantage. Thus we would also expect that the long term GDP level will increase as a result of those measures.

The last point in Table 12 concerns the research programme 'Ambient Assistant Living'. This measure can be expected to positively affect growth, but through a different channel. As this programme is aimed at promoting technological research that is focused on older generations by developing technological solutions and which is also marketable within a relative short time, the supply of such technologies is likely to foster enterprises that are specialized in these areas. As a consequence this measure might lead to positive effects on growth and labour demand on a medium term basis.

\footnotetext{
${ }^{47}$ ICT might potentially lead to a replacement of labour by capital and thus to rationalization with respect to labour input. This effect is sometimes referred to as Substitution or Riccardo's effect. This effect occurs due a decrease in technology prices following technological innovations, which leads to a increase in the relative price of wages. (compare eGEP, 2006).

${ }^{48}$ Felderer, B., Graf, N., Paterson, I., Polasek, W., Schwarzbauer, W., Sellner, R. (2005): The European Services Market in the Context of the Lisbon Agenda - Productivity and Employment in European Services with high Intensity of Information and Communications Technology (ICT) - Study commissioned by the Federal Chancellery of Austria.
} 
Table 12: Summary of ICT Measures listed in NRP

\begin{tabular}{|c|c|c|c|}
\hline Measure & Status & OECD priority ${ }^{49}$ & Expected Effects \\
\hline $\begin{array}{l}\text { Implementation of 'i2010- } \\
\text { Strategy' }\end{array}$ & underway & & $\begin{array}{l}\text { Centrepiece of Lisbon Strategy } \\
\text { for Growth and Employment }\end{array}$ \\
\hline Broadband Initiative & $\begin{array}{l}\text { evaluation by } \\
\text { end of } 2006\end{array}$ & \multirow[b]{2}{*}{ high } & \multirow{2}{*}{$\begin{array}{l}\text { Positive effects for growth and } \\
\text { employment }\end{array}$} \\
\hline $\begin{array}{l}\text { Broadband Initiative } \\
\text { 'Austrian electronic } \\
\text { network' }\end{array}$ & $\begin{array}{l}\text { to be approved } \\
\text { by BMF }\end{array}$ & & \\
\hline ICT-Board & Underway & \multirow{5}{*}{ increasing } & \multirow{5}{*}{$\begin{array}{l}\text { Positive effects, Increased } \\
\text { international competitiveness, } \\
\text { leaner administration }\end{array}$} \\
\hline eCooperation Board & Underway & & \\
\hline Platform ,Digital Austria' & Underway & & \\
\hline Taskforce-ICT & not yet started & & \\
\hline $\begin{array}{l}\text { eGovernment Strategy } \\
2005+\end{array}$ & Underway & & \\
\hline Ambient Assisted Living & Starting & $\begin{array}{l}\text { high and } \\
\text { increasing }\end{array}$ & $\begin{array}{l}\text { Indirect positive effects, R\&D in } \\
\text { ICT area with market potential } \\
\text { (in view of demographics) }\end{array}$ \\
\hline
\end{tabular}

\footnotetext{
${ }^{49}$ Most widely mentioned policy areas, of high and/or increasing priority of surveyed countries; in Science \& Information Technology 2006, vol. 2006, no. 16, pp. 1-315.
} 
Table 13: ICT- Indicators

\begin{tabular}{|c|c|c|c|c|}
\hline Indicator & $\%$ & rank & EU15 & EU25 \\
\hline \multicolumn{5}{|l|}{ General } \\
\hline $\begin{array}{l}\text { Percentage of population with } \\
\text { internet access }\end{array}$ & 47 & 10 & below & below \\
\hline Broadband Penetration & 11.6 & 9 & below & above \\
\hline
\end{tabular}

\section{E-government}

\section{Private}

Percentage of individuals who used Internet, in the last 3 months,

2005

\begin{tabular}{lcccc} 
& $\%$ & rank & EU 15 & EU 25 \\
\hline for downloading official forms & 11 & 15 & below & above \\
for obtaining information from & 25 & 8 & above & below \\
$\begin{array}{l}\text { public authorities web sites } \\
\text { for sending filled forms }\end{array}$ & 12 & 6 & above & above \\
\hline
\end{tabular}

\section{Commercial}

Percentage of enterprises using Internet for interaction with public authorities

2005

\begin{tabular}{lcccc} 
& $\%$ & rank & EU 15 & EU 25 \\
\hline for full electronic case handling & 36 & 4 & above & above \\
for obtaining information & 57 & 15 & above & above \\
for obtaining forms & 69 & 6 & above & above \\
for returning filled in forms & 41 & 13 & above & above \\
\hline
\end{tabular}

\section{E-Commerce}

$\% \quad$ rank 2005 EU 15 EU 25

$\begin{aligned} & \text { Percentage of enterprises' total } \\ & \text { turnover from e-commerce over }\end{aligned}$
the last calendar year

Source: Eurostat, Information Society Statistics. 


\section{Contribute to strong industrial base}

\section{Expected Effects}

In Austria, like in other EU Member States except the UK, companies have typically used the banking sector rather than the stock market in order to raise new funds. Independent of whether financial systems are bank or stock market dominated, the degree of development and the efficiency of the financial system is important - not only for individual companies but also for long-term economic growth.

Well-functioning financial systems - might they be bank or market dominated - have been found to be a key determinant of sustained economic growth. ${ }^{50}$ Financial systems primarily facilitate the allocation of resources, across space and time, in an uncertain environment. ${ }^{51}$ Research divides this primary function into five categories. ${ }^{52}$ Financial systems (i) facilitate the trading, hedging, diversifying, and pooling of risk; (ii) allocate resources; (iii) monitor managers and exert corporate control; (iv) mobilize savings; and (v) facilitate the exchange of goods and services.

In general, there are different ways in which the financial sector can develop: (1) The efficiency and competitiveness of the sector may improve; (2) the range of financial services available may increase; (3) the diversity of institutions operating in the financial sector may increase; (4) the amount of money that is intermediated through the financial sector may increase; (5) the extent to which capital is allocated by private sector financial institutions, to private sector enterprises, responding to market signals (rather than government directed lending by state owned banks) may increase; (6) the regulation and stability of the financial sector may improve; (7) a larger part of the population may gain access to financial services.

Some of these topics can be incorporated formally in endogenous growth models. ${ }^{53}$ Modern growth theory identifies two specific channels through which the financial sector might affect long-run growth: first, through its impact on capital accumulation (including human as well as physical capital) and, second, through its impact on the rate of technological progress. These

\footnotetext{
${ }^{50}$ See, for example, King, Robert and Ross Levine (1993): Finance and Growth, Schumpeter Might Be Right, Quarterly Journal of Economics, 108, 717-737; King, Robert und Ross Levine (1993): Finance, Entrepreneurship and Growth: Theory and Evidence, Journal of Monetary Economics, 32, 513-542; and King, Robert und Ross Levine (1993b): Finance, Entrepreneurship and Growth: Theory and Evidence, Journal of Monetary Economics, 32, 513-542.

${ }^{51}$ Merton, Robert C. und Zvi Bodie (1995): A Conceptual Framework for Analyzing the Financial System, in Dwight B. Crane et al. (eds.): The Global Financial System: A Functional Perspective, Boston, MA: Harvard Business School Press.

52 Levine, Ross (1997): Financial Development and Economic Growth, Views and Agenda, Journal of Economic Literature, 35(2), 688-726.

${ }^{53}$ See, for example, Bencivenga, Valerie R. und Bruce D. Smith (1991): Financial Intermediation and Endogenous Growth, Review of Economic Studies, 58, 195-209 and Greenwood, Jeremy und Boyan Jovanovic (1990): Financial Development, Growth, and the Distribution of Income, Journal of Political Economy, 98, 1076-1107.
} 
effects arise from the intermediation role provided by financial institutions, which enable the financial sector to mobilize savings for investment; facilitate and encourage inflows of foreign capital; and optimise the allocation of capital between competing uses, ensuring that capital goes to its most productive use.

Some papers deal with the primary question whether market-based or bank-based financial systems are better for promoting growth. Cross-country studies based on a large number of countries (both industrial and developing countries) find that more developed financial systems enable higher economic growth rates, independent of whether those are stock market or bank dominated. Looking at growth and investment at the industry level, however, some relation between the structure of countries' financial systems and the growth and investment of industries in these countries can be reported. ${ }^{54}$

Empirical studies examining the effect of financial sector development (FSD) on economic growth have mainly used stock market indicators and indicators describing the banking sector as FSD variables. The most prominent ones are market capitalization in percent of GDP and bank loans to the private sector in percent of GDP. These indicators measure basically the size - which does not necessarily correspond to the degree of development or efficiency of financial systems. Yet, in the absence of better measures for a large sample of countries, these indicators have been widely used.

Estimates of growth effects vary substantially. Regression coefficients of financial sector variables in growth regressions are mostly in the range of 0.005 to 0.15 , when the dependent variable is logarithmic growth and the explaining variable is a measure of financial sector development (volume in percent of GDP). Generally, coefficients are higher when longer periods are considered and when initial GDP per capita is lower. This result indicates that the impact of financial sector development is realized only over long time-periods and that less developed countries - usually suffering from less developed financial systems - benefit more from an increase in financial sector development. Building upon the above argument on the impact of FSD on growth and upon empirical results of studies along this line we do not expect a considerable growth effect as a result of the privatisation of the Austrian Post Offices, since, in our view, it does not significantly improve the financial sector development, which is already fairly good.

\footnotetext{
${ }^{54}$ See, for example, Carlin, Wendy und Colin Mayer (2003): Finance, investment, and growth, Journal of Financial Economics, 69, 191-226 and Carlin, Wendy and Colin Mayer (2000): How do financial systems affect economic performance?, in X. Vives (ed.), Corporate Governance: Theoretical and Empirical Perspectives, New York: CUP, 137-168.
} 


\section{Current situation}

The Austrian Stock Exchange has often been complained to be under-valued. However, measures like the price earnings ratio do not seem to confirm this fact. Figure 16 shows the price earnings ratio for benchmark indices of the EU-15 countries in 2005 and the average of that number in the period 2001-2005. Both graphs show that Austria ranks among the top 3 of the EU-15 Member States.

The Austrian Stock Exchange has indeed taken a number of measures to promote stock market activity; the privatisation schedule of the Austrian Federal Government has also contributed to strengthen the capital market, though; specifically by enabling a number of additional large companies to be listed at the stock market and thus increasing total stock market activity. In terms of stock market capitalisation in percent of GDP, Austria still ranks very low compared to other EU-15 Member States, however, suggesting a moderate degree of financial sector development if interpreted as a FSD variable. As we have argued above, however, market-based systems are not necessarily better than bank-based systems in promoting economic growth; and looking at the FSD variable domestic credit to the private sector, Austria ranks much higher (see Figure 17).

The Österreichische Industrie Holding AG (ÖIAG) is the Austrian Republic's investment and privatisation agency. Depending on its mandate from the Austrian government it partially or fully privatises its companies. Table 14 shows the investment it holds as of Sept 29, 2006. After a large number of privatisations have been carried out over the last years, ÖIAG is left with stakes in only four Austrian companies. Its performance in terms of different variables is shown in Figure 15. In 2006 one privatisation carried through (Austrian Post Offices).

The full privatization of VA Technologie AG and Voestalpine AG was already completed in 2005 and will therefore not be included in the evaluation section. In 2005 total privatization proceeds of ÖIAG amounted to 400 mio $€$. This amount included revenues from selling stakes in VA Technologie AG (146.3 mio $€$ ), Voestalpine AG (245.2 mio $€$ ) and in Telekom Austria (8.5 mio $€$ ). The $14.7 \%$ holding in VA Technologie was sold to Siemens AG Österreich in response to a public takeover bid. The proceeds relating to Voestalpine AG come from a full conversion of exchangeable bonds, which were, prematurely, exercised by the holders. These exchangeable bonds corresponded to a $15 \%$ equity holding. The privatisation of VA Technologie AG and Voestalpine AG was thus completed in 2005.

Similar to the restructuring of financial institutions and above-mentioned privatisations, the Austrian research funding sector and technology cooperation projects were restructured to ensure the optimal allocation of research funds between competing uses and the creation of international R\&D partnerships. 
CIR-CE (Cooperation in Innovation and Research with Central and Eastern Europe) is a new technology cooperation programme with the aim to form strategic R\&D partnerships and create research networks between Austria and partners in Central, Eastern and SouthEastern Europe. For the time being, 14 Projects have been selected for a project time of 12 to 36 months, starting from the beginning of 2006 and with 2,1 million $€$ of funding. Another 3 million $€$ of project funds will be made available for projects in 2007.

The restructuring of the Austrian research funding in 2004 led to the creation of a new central funding agency FFG (Forschungförderungsgesellschaft) for research in the business sector. It comprises several former funding bodies (FFF, TIG, ASA, BIT) and was set up with the intention to centralize research funding (one-stop-shop) in different fields (industrial basic research, business innovation and international cooperation) in order to increase funding and research efficiency. Together with the restructuring, the financial funds of the FFG have been raised by contributions from other research programmes so that the yearly research budget of the FFG amounts to approximately 420 million $€(2006){ }^{55}$

\section{Evaluation of actions in NRP:}

In May 2006 the public offering of 34.3 mio shares (including over-allotment options) by Österreichische Post AG was successfully carried out. A total of $49 \%$ of the share capital was sold, generating sales proceeds of approx. 650 mio $€$. After this public offering, the ÖIAG is left with a $51 \%$ holding in the company. With company shares being eight times subscribed, the IPO was very successful. After the first trading day, the share was quoted $10 \%$ above the issue price of $€ 19$. One third of the shares allocated went to private and institutional investors in Austria, the remainder was bought by to international investors.

\section{Effects of NPR measures on GDP and employment:}

Following the line of argument concerning the impact of financial sector development on economic growth, the privatisation of the Austrian Post Offices will have very little growth effect through the described channel since its volume seems to be too small.

New technology cooperation programmes (such as CIR-CE) and the restructuring of the Austrian research funding sector to use synergies of central handling (FFG) are expected to have positive long run effects on growth. Similar to other effects in this area, their nature is very indirect and diffuse and cannot be quantified.

\footnotetext{
${ }^{55}$ homepage of the FFG, in: http://www.ffg.at/content.php?cid=7 and BMWA, BMF, Wirtschaftsbericht Österreich 2006, Wien.
} 
Table 14: ÖIAG Portfolios of Listed Companies

\begin{tabular}{|c|c|c|c|c|c|}
\hline & $\begin{array}{c}\text { Number } \\
\text { Of shares } \\
\text { mio }\end{array}$ & $\begin{array}{c}\text { Number } \\
\text { of shares } \\
\text { ÖIAG } \\
\text { mio }\end{array}$ & $\begin{array}{l}\text { ÖIAG } \\
\text { share }\end{array}$ & $\begin{array}{c}\text { Share price } \\
29.09 .2006 \\
\text { EUR }\end{array}$ & $\begin{array}{c}\text { Market Value } \\
\text { ÖIAG } \\
\text { 29.09.2006 } \\
\text { mio EUR }\end{array}$ \\
\hline OMV & 300 & 94.50 & $31.5 \%$ & 40.86 & $3,861.27$ \\
\hline AUA & 34 & 13.50 & $39.7 \%$ & 7.27 & 98.15 \\
\hline Telekom Austria & 500 & 125.92 & $25.2 \%$ & 19.90 & $2,505.81$ \\
\hline POST AG & 70 & 35.70 & $51.0 \%$ & 30.05 & $1,072.79$ \\
\hline Total & & & & & $7,538.01$ \\
\hline
\end{tabular}

Source: ÖIAG, http://www.oeiag.at/upload/Portfolio 200609 e.pdf.

Figure 15: ÖIAG Performance 2000-2006

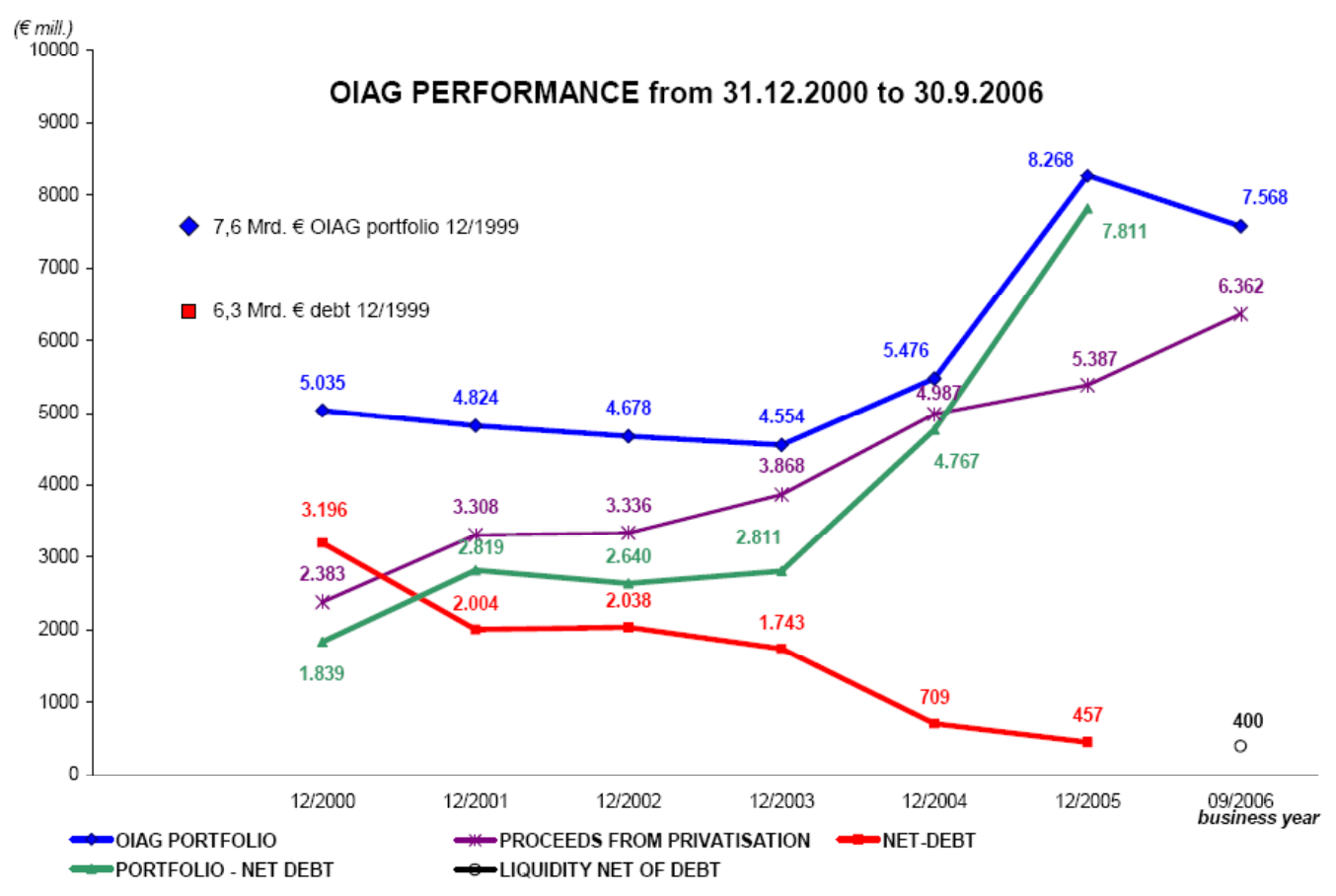

Source: ÖIAG, http://www.oeiag.at/upload/OIAG Wertentwicklung 200609 e.pdf. 
Figure 16: Price Earnings Ratio of Benchmark Indices in 2005 and 2001-2005.

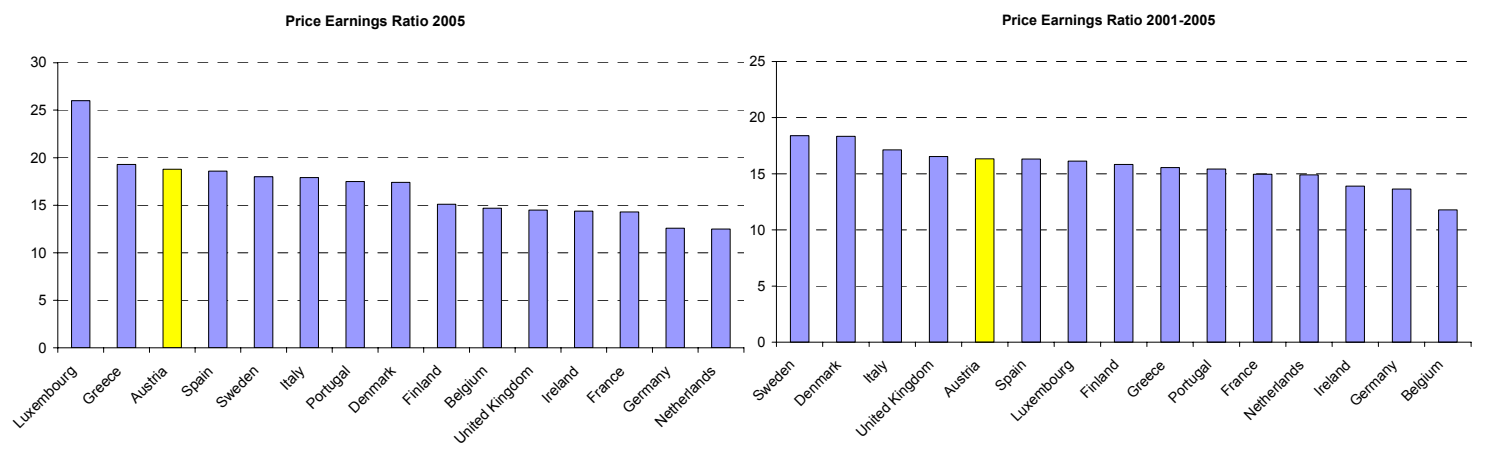

Source: Thomson Financial DataStream.

Figure 17: Financial Sector Indicators in 2004 and 2000-2004.

The figure shows market capitalisation in percent of GDP and domestic credit to the private sector in percent of GDP for the EU-15 countries.
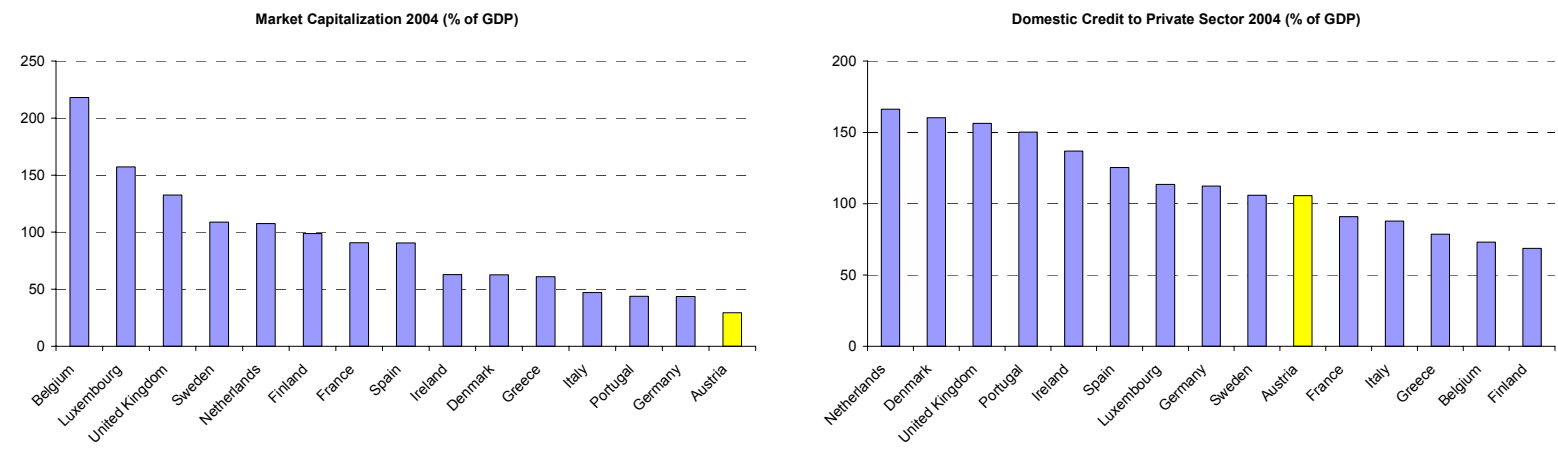

Market Capitalization 2000-2004 (\% of GDP)
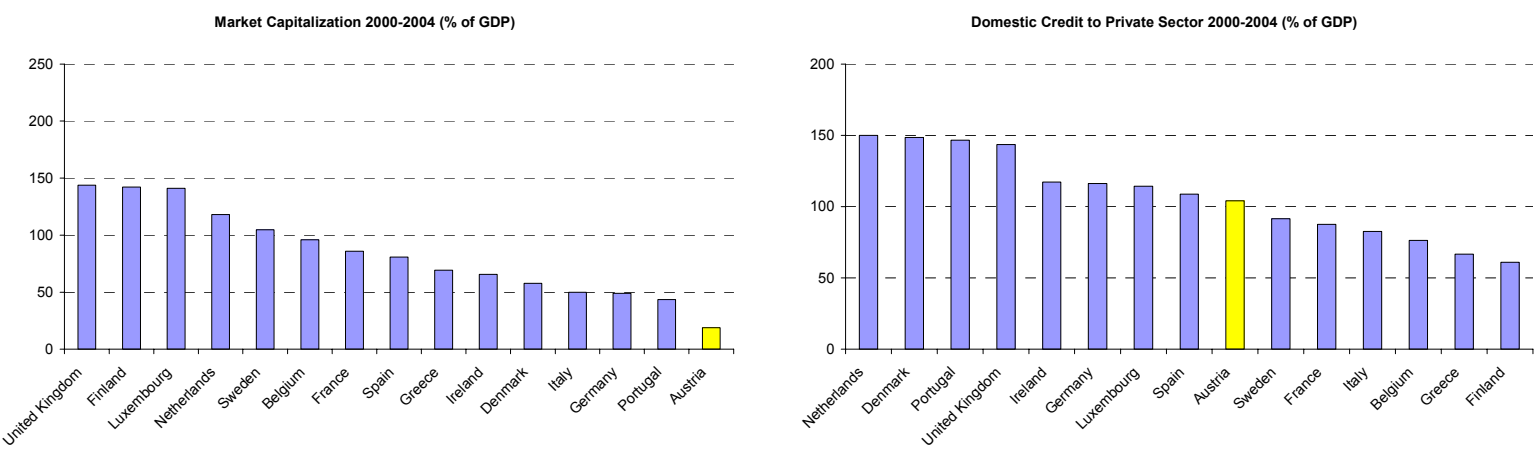

Source: World Development Indicators. 


\section{Extend and deepen the internal market for financial services}

The primary aim of this policy field is to integrate and consolidate the European Union financial sector and thereby increase its efficiency. For expected effects of such measures refer to the above section on "contributing to a strong industrial base" (see page 66).

Empirical studies on the effect of securities market integration have estimated significant economic benefits. A study prepared by London Economics with Price Waterhouse Coopers provided a conservative estimate of a $1.1 \%$ increase in the baseline level of EU GDP over 10 years. The second study, prepared by the Centre for Economic Policy Research found that the growth rate in the value-added in EU manufacturing would increase by $0.7 \%{ }^{56}$

\section{Current situation}

The Financial Services Action Plan (FSAP) was established in $1999^{57}$ to provide advice to strengthen the financial systems of member countries by facilitating early detection of financial sector vulnerabilities and helping to identify financial sector development needs. The EU's Financial Services Action Plan was designed to open up a single market for financial services in the EU. Begun in 1999, it comprises 42 measures ${ }^{58}$ designed to harmonise the member states' rules on securities, banking, insurance, mortgages, pensions and all other forms of financial transaction. Table 15 lists the relevant directives that have been transposed into national law up to $2005 .{ }^{59}$ Austria has been able to meet the transposition deadlines in most cases in the past.

In 2004 Oesterreichische Kontrollbank (OeKB), the organization that had acted as clearing and settlement agent for cash market products up to then, and Wiener Börse AG, the exchange operating company and clearing house for derivate products jointly established the company $\mathrm{CCP}^{60}$ Austria Abwicklungsstelle für Börsengeschäfte $\mathrm{GmbH}$ (CCP.A). CCP.A successfully started operations as the central counter party for all exchange trades in securities and derivatives in the beginning of 2005.

While in the US there is one central corporation providing clearing and settlement services, the European clearing and settlement market is still highly fragmented with a substantial number of different national and international providers of these services. Empirical analyses suggest that clearing and settlement costs in Europe are substantially higher than in the US

\footnotetext{
${ }^{56}$ The Giovannini Group (2003): Second Report on EU Clearing and Settlement Arrangements, Brussels, p.39.

${ }^{57}$ Financial Services: Implementing the Framework for Financial Markets: Action Plan, COM(1999)232, 11.5.1999

${ }^{58}$ The current FSAP list includes 44 measures, see FSAP Evolution Chart, http://ec.europa.eu/internal market/finances/actionplan/index en.htm\#transposition. Communication on Clearing \& Settlement and Regulation on Cross-border Payments were added to the original FSAP.

${ }^{59}$ See documents on the transposition of FSAP directives (Oct 9, 2006) at http://ec.europa.eu/internal market/finances/actionplan/transposition.

${ }^{60}$ CCP stands for central counterparty.
} 
and that there is a large contrast in the cost efficiency of settling domestic and cross-border securities transactions in the European Union. ${ }^{61}$ Several national markets still work with more than one central counter parties in exchange trading - like Austria did prior to the foundation of CCP.A.

The aim of the Single European Payment Area (SEPA) is to establish an integrated market for non-cash payment services, which is subject to effective competition and where there is no distinction between cross-border and national payments within the euro area. Three payment instruments are concerned: direct debits, credit transfers and debit cards. The process will take place in two stages: on 1 January 2008, euro area banks will start to provide users with the SEPA compliant euro payment instruments designed by the European Payments Council (EPC), ${ }^{62}$ i.e. pan-European direct debit and credit transfer. By end 2010, the SEPA payment instruments are due to replace permanently all former domestic instruments.

The realization of the Single European Payment Area is expected to increase competition and facilitate new business opportunities, thereby resulting in gains for society. Although the SEPA realization is of political importance, it has been primarily be seen as a market-led process, which would only be supported by policy actions when necessary. Work on SEPA implementation is closely watched and guided by the European Commission (EC) and the European Central Bank (ECB).

\section{Evaluation of actions in NRP:}

Table 16 lists the FSAP Directives to be transposed in 2006 and early 2007. The transposition of two of these directives, a cornerstone within FSAP, has been completed: The Austrian federal law implementing the EU Capital Requirements Directives (Basel II) was published on Aug 11, 2006 in BGBI. I Nr. 141/2006. The transposition of the Transparency Directive is close to completion - the end of the bill's examination period was Sept 29, 2006. The transposition of the directive relating to the third measure, the Markets in Financial Instruments Directive, is still at an early stage, though. The Federal Ministry of Finance plans to have a bill ready for examination early 2007 and thus will not be able to meet the transposition deadline of Jan 30, 2007. Also other EU member countries seem to be behind concerning the transposition of MiFID.

\footnotetext{
${ }^{61}$ See NERA Economic Consulting (2005): The Future of Clearing and Settlement in Europe, City Research Series 7, London and The Giovannini Group (2001): Cross-Border Clearing and Settlement Arrangements in the European Union, Brussels.

${ }^{62}$ It was created by the EU banking industry in response to the EC regulation stating that domestic and cross-border payments within the euro area are to be charged equally.
} 
The overall goal of FSAP measures is to improve the efficiency of the EU financial sector being one single financial system rather than a collection of separate national systems - as a motor for economic growth. While assessing the effect of individual FSAP measures on economic growth is not feasible, it has become undisputable that there is a strong link between financial development, and thus the FSAP measures, and economic growth.

The positive effect of having a single central counter party, like CCP.A in Austria, continues to be present also one year after its introduction. The efforts of removing the barriers to integrated and efficient EU trading, clearing and settlement, however, have to be continued, in particular in the direction of having pan-European systems and clearing houses.

In the SEPA process, the Austrian Federal Ministry of Finance in cooperation with Oesterreichische Nationalbank wrote a comment in response to a consultative paper ${ }^{63}$ which had been published by the European Commission as a basis for consultation and discussion. The Austrian comment confirmed the Commission's view that SEPA should remain a primarily market-led process and that continued self-regulation should be supported. This also means that it is not primarily the Austrian government's task to pursue SEPA actions. In 2005, OeNB had initiated to implement the Austrian Payments Council (APC) with mirror groups of the EPC working groups. The APC is supposed to act as central communication and project platform for the Austrian banking industry during the SEPA process.

\section{Effects of NPR 2006 measures on GDP and employment:}

The actions listed in the NRP, in particular FSAP and SEPA, constitute an integral part of EU-wide programmes extending over longer time periods. Since the impact of the actions set in 2006 will be realized only long-term (and probably not be distinguishable from actions in the same programme taken in 2005 and 2007), we can only give an extremely rough estimate based on empirical studies reviewed above.

Provided all FSAP and SEPA actions have been successfully implemented, the overall longterm growth rate may be affected marginally.

${ }^{63}$ European Commission (2006): Consultative Paper on SEPA Incentives, Feb 132006. 
Table 15: Transpositions of FSAP Directives, European Commission FSAP

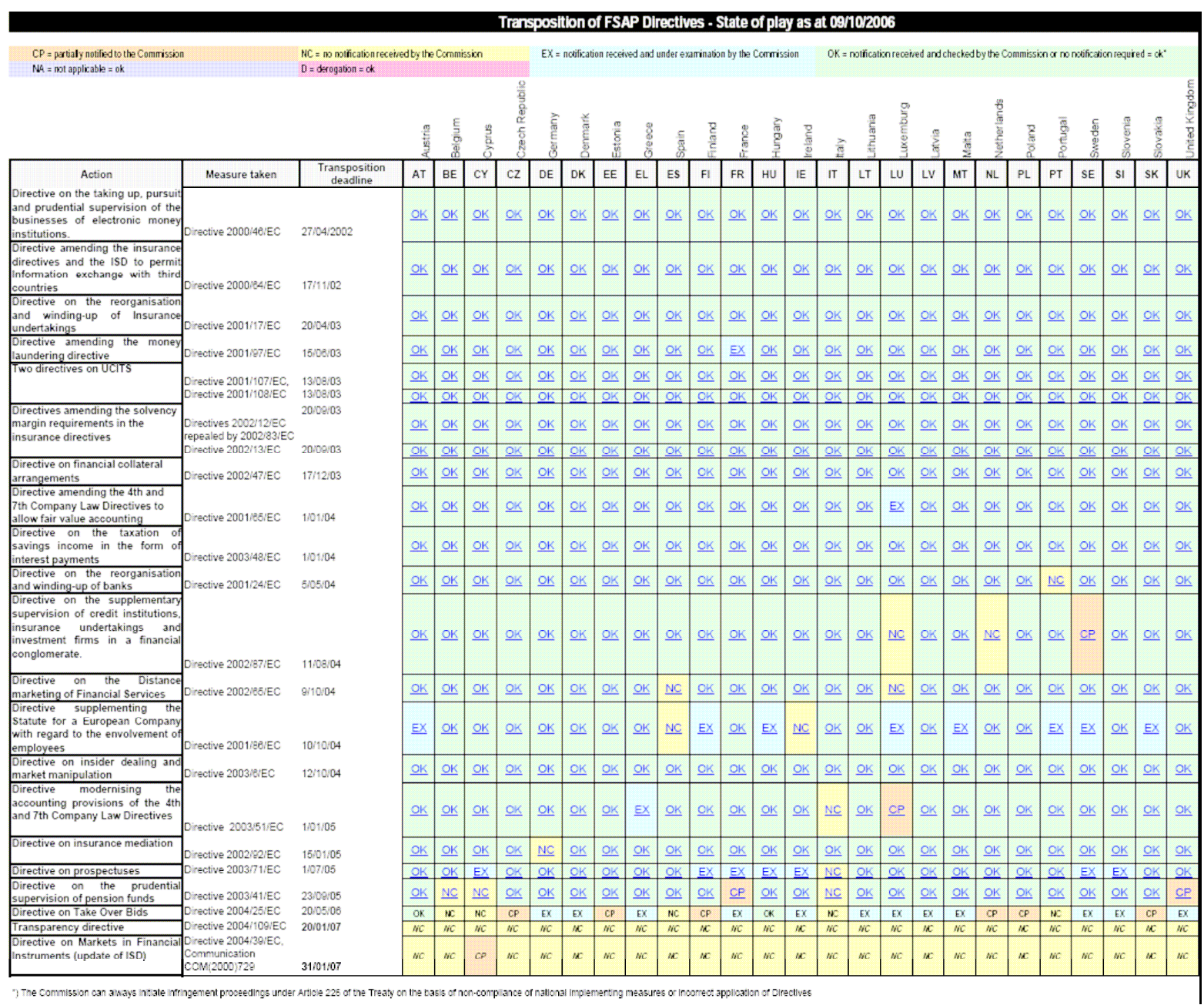

Table 16: FSAP Directives to be transposed into national law in 2006 and early 2007.

\begin{tabular}{|c|c|}
\hline Measure Planned & Measure Taken \\
\hline $\begin{array}{l}\text { Amend the directives } \\
\text { governing the capital } \\
\text { framework for banks } \\
\text { and investment firms }\end{array}$ & $\begin{array}{l}\text { Directive 2006/48/EC relating to the taking up and pursuit of the business of } \\
\text { credit institutions (recast) and Directive 2006/49/EC on the capital adequacy of } \\
\text { investment firms and credit institutions (recast). } \\
\text { (Capital Requirements Directives, CRD) } \\
\text { Transposition Deadline: } 31 \text { Dec } 2006 \\
\text { Date of Effect: } 1 \text { Jan } 2007\end{array}$ \\
\hline $\begin{array}{c}\text { Update the Directive } \\
\text { on Regular Reporting } \\
(82 / 121 / \text { EEC })\end{array}$ & $\begin{array}{l}\text { Directive } 2004 / 109 / E C \text { on "the harmonisation of transparency requirements in } \\
\text { relation to information about issuers whose securities are admitted to trading } \\
\text { on a regulated market and amending Directive 2001/34/EC". } \\
\text { (Transparency Directive) } \\
\text { Transposition Deadline: } 20 \text { Jan } 2007\end{array}$ \\
\hline $\begin{array}{l}\text { Green Paper on } \\
\text { upgrading the ISD }\end{array}$ & $\begin{array}{l}\text { Directive 2004/39/EC on "markets in financial instruments amending Directives } \\
\text { 85/611/EEC, 93/6/EEC and 2000/12/EC and repealing Directive 93/22/EEC". } \\
\text { (Markets in Financial Instruments Directive, MiFID) } \\
\text { Transposition Deadline: } 31 \text { Jan } 2007 \\
\text { To be applicable from } 1 \text { Nov } 2007\end{array}$ \\
\hline
\end{tabular}




\section{Safeguard economic position and encourage SMEs Expected Effects of reformed Competition Law}

A cartel is a formal agreement among firms in an oligopolistic industry. ${ }^{64}$ According to theories of (cooperative and non-cooperative) oligopoly and (restricted) competition, ${ }^{65,66}$ cartel behaviour attempts to emulate that of monopoly by restricting industry output, raising or fixing prices in order to earn higher joint monopoly profits. Collusion between firms, for example to raise or fix prices, even without a formal cartel agreement, can lead to the same negative welfare effects.

Competition law in Austria has thus been brought in line with European Community law by the introduction of legal exceptions in the application of the law to avoid the formation of cartels. The main thrust of the change is the introduction of a principal witness leniency programme. Experience in Europe shows that his measure is vital for an efficient dismantling of cartels. The law has been modernised is line with EC law (Council Regulation (EC) No. 1/2003) and came into force on January 1 2006. The adaptation of Austrian law was not mandatory, however there should efficiency gains accruing through this simplification for competition authorities in Austria and the EU.

The leniency programme implies that the competition authority may refrain from applying to impose an administrative fine if the following conditions are met: The undertaking has stopped participating in a cartel; it has informed the Federal Competition Authority (FCA), before it found out about the facts of the case itself; it cooperates with the FCA without restrictions and it has not forced others to participate in the cartel. If the applicant only fails to inform the FCA in time he may apply for a reduced fine.

Due to the harmonisation of Austrian competition law with EU competition law the evaluation is expected to be positive. The 2005 progress report mentions the steps Austria is taking to improve its regulatory environment, particularly by reducing administrative costs and boosting competitiveness. In related areas, the report laments the lack of measures to improve competition in services and liberal professions in particular, and these aspects are also not addressed in the NRP.

Inasmuch as competition serves the interests of firms and consumers, innovation and thus investment in new products is promoted and welfare gains arise from an increasing efficiency of competition law and effectiveness of the competition authority. The registration of mergers with the Federal Competition Authority (in place of the Cartel Court previously) is claimed by

\footnotetext{
${ }^{64}$ Glossary of Industrial Organisation Economics and Competition Law, OECD.

${ }^{65}$ G.J. Stigler, 1964, A Theory of Oligopoly, Journal of Political Economy, Vol. 72(1), 44-61.

${ }^{66}$ F.M. Scherer and D. Ross (1990), Industrial Market Structure \& Economic Performance, Houghton Mifflin, Boston.
} 
the Federal Ministry for Economics and Labour to simplify administrative procedures; a higher administrative burden, however, now falls on the FCA, which dealt with 130 cases in the first half-year of 2006.

Whereas the changes to the law are not expected to bring significant quantifiable direct benefits in terms of employment and economic growth, a better functioning competitive environment has, however, indirect beneficial effects. Effective prevention of cartels implies decreasing the curbs on competition. As the $\mathrm{OECD}^{67}$ points out in the related context of product markets, regulations that curb competition may have several consequences for labour demand both at the firm level and in the aggregate. At the firm level, the presence of market power tends to reduce the wage elasticity of demand and shift inwards the labour demand schedule ${ }^{68}$ In addition, product market rents prompt employees to ask for wage premia. Ceteris paribus, this induces firms to choose capital-labour ratios higher than in a competitive situation, causing lower employment and productive inefficiencies.

A related benefit of this phase of European harmonisation will emerge if more private actions for antitrust damage are brought in the courts of EU member states in future. The European Commission is proposing in a Green Paper $^{69}$ to investigate how to change the historically low incidence of such cases in Europe, compared to the situation in the USA. This effect would be in addition to the public enforcement actions that may be brought by the Commission and national competition authorities, now that the provisions of Articles 81 and 82 of the EC Treaty, which are roughly comparable to Sections 1 and 2 of the US Sherman Act, are directly applicable.

To sum up, changes to competition law are not expected to bring any direct benefits in terms of employment and economic growth. ${ }^{70}$ Yet, a better functioning of competition law is expected to exert indirect positive effects.

${ }^{67}$ G. Nicolleti and S. Scarpeta (2005), Product Market Reforms and Employment in OECD Countries, OECD Economics Department Working Papers No. 472.

${ }^{68}$ Hicks, J. (1935), "Annual Survey of Economic Theory: the Theory of Monopoly", Econometrica, Vol.3, pp.1-20.

${ }^{69}$ European Commission Green Paper: Damages Actions for Breach of the EC Antitrust Rules, Brussels (Dec. 19, 2005), SEC (2005) 1732, http://europa.eu.int/comm/competition/antitrust/others/actions for damages/gp en.pdf.

${ }^{70}$ Vorblatt zu 926 Regierungsvorlage, p. 1. 


\section{Impact of openness on economic growth ${ }^{71}$}

\section{Expected Effects}

International trade has contributed to sustainable development in a number of countries. In particular for small and open economies, foreign trade has been a major source of growth. A comparison of the first half of the 1970s with the period 2001 to 2005 reveals that all industrialised countries have increased their trade share (Figure 18).

Researchers have devoted much effort to the question of whether higher trade openness stimulates economic growth. Most of the evidence is based either on case studies or on regression analysis, in which trade shares, tariff indexes, import duties, and black market premiums are explanatory variables. Lee et al. (2004) found that measures of openness have a positive impact on economic growth. Also Alcala et al. (2004) found that international trade has an economically significant and statistically robust positive effect on productivity. Both also found a significantly positive aggregate scale effect.

Open economies benefit from globalisation because they have access to new sources of supply for raw and intermediate materials, final consumer and producer goods, and labour. This reduces the domestic inflationary pressure on prices and wages.

However, the openness of countries is not only restricted to real economy transactions. Capital markets too have become increasingly global, which made them broader and more liquid but also increasing vulnerability to financial crises and volatility in stock markets.

Cross border capital movements have gained increasing importance since the beginning of the 1990s. The ongoing integration process of the international capital market allows an open economy to borrow resources from the rest of the world or to lend them abroad. With the aid of foreign loans, an economy with a temporary income shortfall can avoid a sharp contraction of consumption and investment. Similarly, a country with ample savings can lend and participate in productive investment projects overseas. Because international borrowing and lending are possible, there is no reason for an open economy's consumption to be closely tied to its current output.

\footnotetext{
${ }^{71}$ References for Impact of openness on economic growth: Lee, H., Ricci, L. \& Rigobon, R. (2004). Once again, is openness good for growth, Working Paper 10749, NBER; Alcala, F., \& Ciccone, A. (2004): "Trade, and Productivity." Quarterly Journal of Economics, vol. 119, no. 2; , Institute for Advanced Studies (HIS, 2006), Austrian Economic growth forecast 2006-2007Quarterly report; OeNB (2006), Statistisches Monatsheft; OeNB (2006), Sonderheft Statistiken, Direktinvestitionen 2004; Statistik Austria (data) and OECD, Economic Outlook.
} 


\section{Austrian Trade performance ${ }^{72}$}

Austria is a small and open economy. Its degree of openness is relatively high with respect to the other industrialised countries. Only the Netherlands, Ireland, Belgium, Hungary and the Czech Republic are more open (Figure 18). The Austrian export and import ratio has been steadily increasing over time, however, a structural break occurred in 1993. From than on, the opening process accelerated (Figure 19) and the share of total exports in GDP increased by one third from 1996 to 2005 .

Within total exports, the export of goods is of major importance, while the export share of the services sector is relatively small with transportation and knowledge based services being the most important sectors within business related services exports. Foreign direct investments (FDI) abroad grew slightly in the last four years (Table 17). Since growth potentials in business related service exports are not exhausted, companies intending to enter this export market should be supported and the tourism sector should be restructured.

In 2006, the share of total exports in GDP amounted to $55.7 \%$ as compared to $54.3 \%$ in the previous year. This positive trend in internationalisation is expected to continue since total exports as a share of GDP will further increase in 2007. The biggest contribution came from the exports in goods with a share of $43.2 \%$ in GDP. The export share of the services industries is relatively small, as in 2006 the exports in business related services and tourism amounted to $6.2 \%$ and $6.3 \%$ respectively. ${ }^{73}$

In the past decade (1996 to 2005), total exports, on a yearly average, have contributed 3.1 percentage points to the growth of the gross domestic product (GDP) while the average growth rate of the GDP during the same time amounted to $2.2 \%$. Due to its increasing share in total economic activity, the contribution of exports to growth will further increase. It primarily comes from the exports of goods; growth contributions from services exports are limited (Figure 20). This year the volume of total exports will grow by $4.6 \%$, to $133.1 \mathrm{Bio}$. $€$. In 2007 exports may increase by $6.8 \%$ reaching an amount of 142.2 Bio. $€$.

For a small and open economy as Austria specialisation is essential. The Austrian economy strongly depends on exports of automotive goods and parts. Since this sector performed well in the neighbouring countries in the last years, achieved good trade results. Another positive factor for the Austrian foreign trade sector is the country's geographic closeness to Central and Eastern European Countries. In particular during the 1990s, the Austrian trade sector has strongly benefited from the demand in these countries. Both factors positively influenced

\footnotetext{
${ }^{72}$ The following analysis is based on the actual data released by Statistik Austria and the Austrian National Bank (OenB). All indications for the years 2006 and 2007 are forecasts of the Institute for Advanced Studies (IHS), published in October 2006.

${ }^{73}$ For a more detailed analysis of exports of goods, services and foreign direct investment refer to the ANNEX.
} 
the export ratio, which attained the governments target value of $40 \%$ (for 2007) already in 2005. Similarly, the target export value of 100 billion $€$ (for 2007) was achieved in 2005.

The initiative "go international" was started in 2003 with the goal to promote and guarantee the future competitiveness of the Austrian foreign trade sector and improve existing structural weaknesses. The exports of goods, services and FDIs are considered to be the three pillars of the Austrian internationalisation programme. Due to its success, the initiative has been prolonged until 2007.

The Ministry of Economics and Labour and the foreign trade branch of the Austrian Federal Economic Chamber support the initiative with measures worth 50 million $€$ each whereof a "Quick-Starter Package“ with a volume of 17 million $€$ became operational in 2003 already. The major goals of "go international" are: (1) the duplication of the number of exporting enterprises, (2) the enlargement of the regional distances of trade, (3) stronger support for the services sector, including tourism industry with respect to its export activities; (4) the increase of the Austrian foreign direct investment (FDI) activities, (5) a greater diversification in traded goods and services across regions and industrial sectors, (6) the removal of trade barriers for SMEs, (7) the share of goods exports in GDP should surpass the 40-percent benchmark by 2007 and (8) the exports of goods should reach a volume 100 Bio. $€$ by 2007 .

Conclusion: In the current and next year, foreign trade will remain a major source for growth in the Austrian economy. The Institute for Advanced Studies expects that exports will contribute, on a yearly average, 3.3 percentage points to the GDP growth rate. Due to the efforts of the initiative "go-international" the services exports - now still quite small - might gain weight. 
Table 17: Export shares in total GDP according to selected sectors (in \% of GDP)

\begin{tabular}{|l|l|l|l|l|l|l|l|}
\hline & total & goods & tourism & $\begin{array}{l}\text { business } \\
\text { related } \\
\text { services }\end{array}$ & & & \\
\hline & & & & total & transport & $\begin{array}{l}\text { knowledge } \\
\text { of active } \\
\text { FDI }\end{array}$ \\
\hline 1990 & 37.7 & 24.9 & 8.3 & 4.5 & n.a. & n.a. & n.a. \\
\hline 1991 & 36.4 & 23.8 & 8.1 & 4.5 & n.a. & n.a. & n.a. \\
\hline 1992 & 34.9 & 22.8 & 7.5 & 4.6 & 1.6 & 0.8 & -0.1 \\
\hline 1993 & 33.1 & 21.2 & 7.1 & 4.7 & 1.6 & 0.8 & 0.0 \\
\hline 1994 & 33.6 & 22.1 & 6.5 & 5.0 & 1.7 & 0.9 & 0.1 \\
\hline 1995 & 35.1 & 24.1 & 6.1 & 4.9 & 1.6 & 1.0 & 0.0 \\
\hline 1996 & 35.9 & 24.5 & 5.9 & 5.4 & 1.7 & 1.2 & 0.3 \\
\hline 1997 & 39.7 & 28.1 & 5.9 & 5.8 & 1.9 & 1.2 & 0.4 \\
\hline 1998 & 41.7 & 29.3 & 5.9 & 6.5 & 2.1 & 1.4 & 0.4 \\
\hline 1999 & 42.7 & 30.2 & 5.9 & 6.5 & 2.0 & 1.3 & 0.6 \\
\hline 2000 & 45.4 & 33.2 & 5.9 & 6.4 & 2.2 & 1.4 & 0.7 \\
\hline 2001 & 47.8 & 34.6 & 6.2 & 7.0 & 2.6 & 1.7 & 0.6 \\
\hline 2002 & 48.8 & 35.3 & 6.3 & 7.1 & 2.8 & 1.6 & 1.3 \\
\hline 2003 & 48.4 & 35.0 & 6.4 & 7.0 & 2.9 & 1.6 & 1.4 \\
\hline 2004 & 51.6 & 38.2 & 6.3 & 7.1 & 3.2 & 1.6 & 1.8 \\
\hline 2005 & 54.3 & 40.1 & 6.3 & 7.8 & 3.5 & 1.7 & 2.3 \\
\hline $2006^{*}$ & 55.7 & 43.2 & 6.3 & 6.2 & n.a. & n.a. & n.a. \\
\hline $2007^{*}$ & 58.2 & 45.8 & 6.3 & 6.2 & n.a. & n.a. & n.a. \\
\hline
\end{tabular}

Source: Statistik Austria, OeNB, IHS; *) IHS-Forecast, n.a. = not available.

Figure 18: Openness of Industrialised Countries

Graph 1:

Openness of industrialised countries

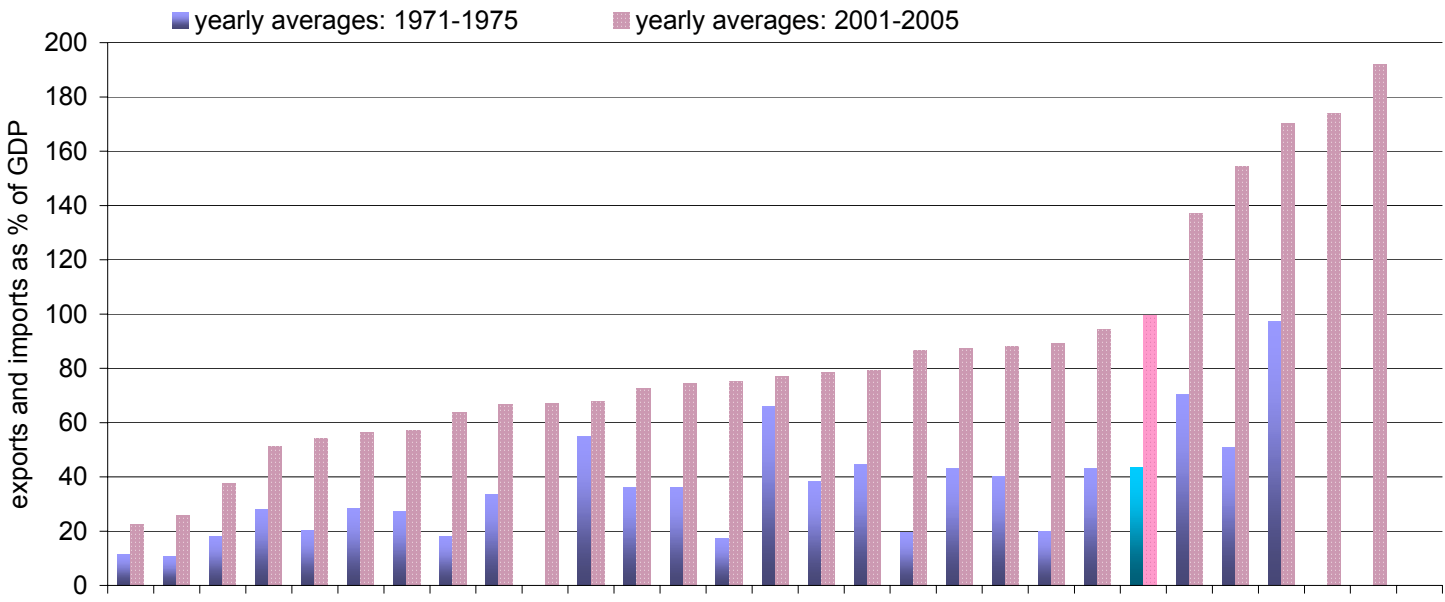

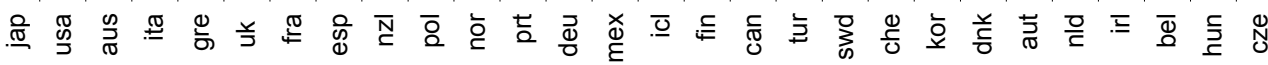
Sources: OECD, IHS-calculations. 
Figure 19: Degree of Openness of the Austrian Economy

Graph 2:

Degree of openness of the Austrian economy

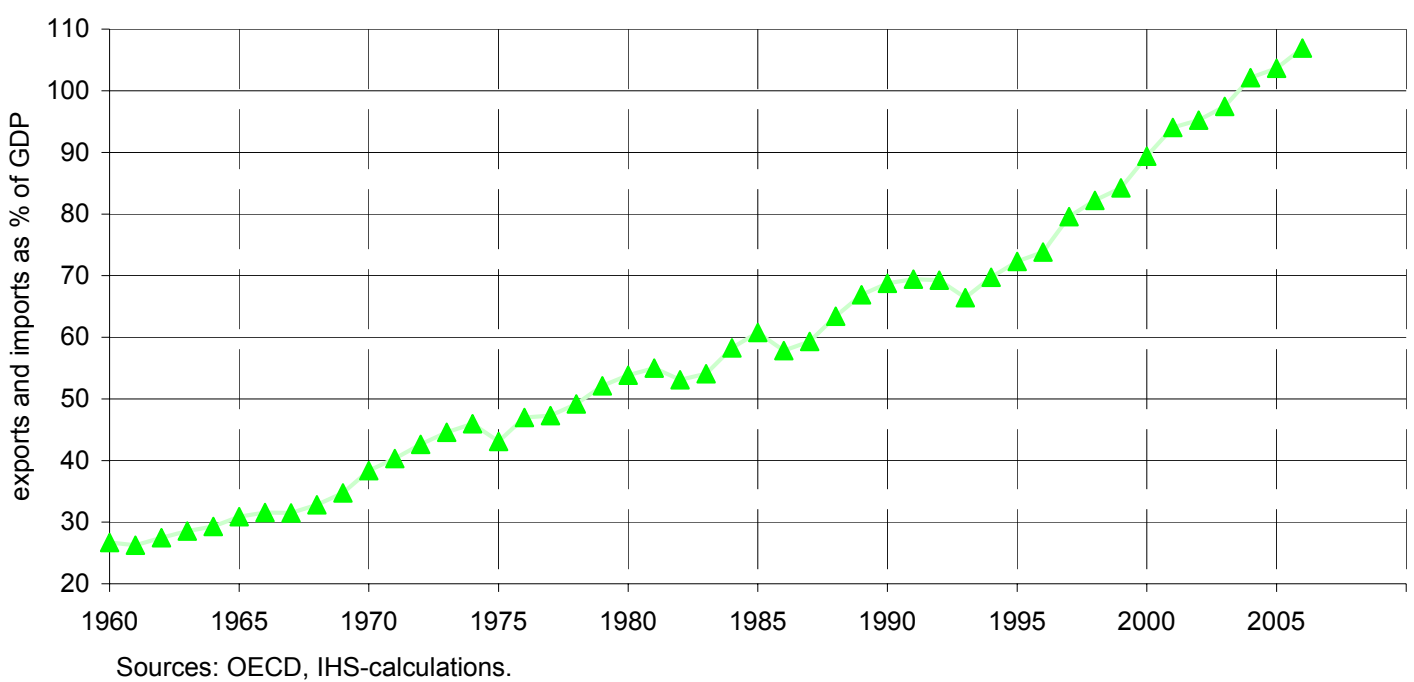

Figure 20: Contribution of exports to GDP growth (Austria)

Graph 3:

Contribution of exports to GDP growth

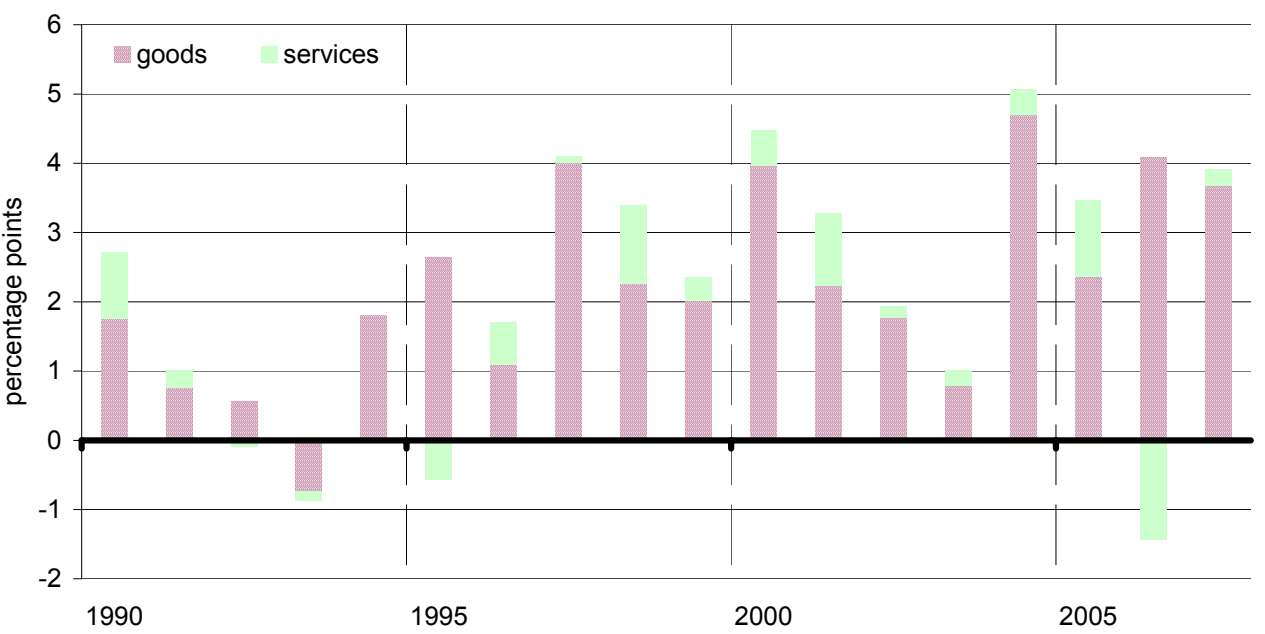

Sources: Statistik Austria, IHS-calculations 


\section{Better Regulation, Entrepreneurial Culture and SME Support Present situation and expected Outcomes}

In order to create a more competitive business environment and encourage private initiative through better regulation, EU Member States are invited to reduce administrative burdens (particularly for SMEs), simplify tax systems, strengthen access to finance and improve the quality of existing and new regulations concerning business activities. It is also vital to provide access to micro loans and various forms of risk capital to promote entrepreneurial culture and create a SME-supportive environment.

The ENSR (European Network for SME Research) Survey 2003 underlined the importance of access to finance and effective administrative regulations, especially for SMEs. Beside the lack of purchasing power of customers and the lack of skilled labour, the absence of favourable financial and administrative conditions was identified as the third main constraint for good business performance. ${ }^{74}$

Compared to large scale enterprises (LSEs), the financing for SMEs may be more costly ${ }^{75}$ and access to debt financing more difficult, due to additional collateral requirements. In countries like Austria, Denmark, Finland, Germany or Spain, the equity ratio of small enterprises is lower than in medium-sized enterprise and whereas interest rates on capital are higher.

Country differences in equity ratio might be a consequence of differing taxation systems (percentage of income tax versus corporation tax), financial systems (market-based versus bank-based financing systems), legal framework conditions (accounting regulations or requirements of minimum equity for start-ups) and 'financing traditions'. Sectoral differences are primarily due to variations in capital demand.

With lower equity ratios, small companies have a higher need for external finance which constitutes a handicap for SMEs if barriers to external finance exist. Micro enterprises in Austria (Table 18) have less equity than those in other EU Member States, which suggests that an easier access to finance and lower administrative burdens could generate growth .

Micro enterprises with a maximum of 10 employees represent $90 \%$ of all Austrian enterprises and employ $17 \%$ of Austrian employees (2005). In the same year, one-personenterprises accounted for $50 \%$ of all enterprises ${ }^{76}$ (Figure 21). A survey ${ }^{77}$ shows, that $29 \%$

\footnotetext{
${ }^{74}$ European Commission, Observatory of European SMEs 2003, No. 8, Highlights from the 2003, pp. 15. http://ec.europa.eu/enterprise/enterprise policy/analysis/doc/smes observatory 2003 report8 en.pdf.

75 European Commission, Observatory of European SMEs 2003, No. 2, SMEs and Access to Finance, http://ec.europa.eu/enterprise/enterprise policy/analysis/doc/smes observatory 2003 report2 en.pdf.

${ }^{76}$ Österreichische Wirtschaftskammer (WKÖ).
} 
of these one-person-enterprises would be willing to hire people in the next three years if economic circumstances permit. The main obstacles against employing additional labour are seen in high time consumption (68\%), tax and social insurance regulations (66\%) and missing financing for start ups $(50 \%)$, which corresponds to the results of the EU Commissions SME observatory. Within a favourable framework and under the presumption that - within the next three years - micro enterprises will employ 5 workers on average and a third of the one-person-enterprises one worker, the annual employment effect of start-ups would be up to 61.489 additional jobs (or $21 \%$ of all employees in base year 2005).

\section{Evaluation of NRP Initiatives}

The SME Initiative 2006 was established in summer 2006 to complement the 2004/5 tax reform which mainly benefits medium and large enterprises through the reduction of corporate tax and the implementation of group taxation. It provides financial advantages for sole proprietorship enterprises, such as a $10 \%$ tax allowance on annual profits, an increase in tax free turnover (now $30,000 €$ ), access to micro loans, increased coverage of doubleequity loan guarantees (now 2 Mio $€$ ) and higher coverage of loans for capital equipment (now $80 \%$ ). In 2005, approximately $70 \%$ of existing Austrian micro enterprises and $82 \%$ of start-ups have benefited from the higher tax allowances and group taxation.

Other loan guarantees offered by the ERP-fund and the government are managed by AWS (Austria Wirtschaftsservice) which reported 220 cases of access to loan guarantees in the first quarter of 2006. In view of the large and increasing number of micro enterprises, the services of the AWS should be continuously widened, particularly for sole proprietorship and should also comprise consultancy for start ups and established companies.

Standard cost model: According to the Observatory of European SMEs, administrative regulations represented major business constraint for about $10 \%$ of all SMEs in 2003. In order to assess cost and benefits of legislative initiatives, the Austrian Federal Government launched in April 2006 an initiative for reducing the administrative burdens for enterprises incurred as a result of information and reporting obligations. The aim is to reduce administrative costs by $25 \%$ by 2010 , using the Dutch Standard Cost Model, thus saving approximately $€ 2$ billion. Between November 2006 and June 2007, a so-called baseline measurement of the existing federal legislation containing information obligations for companies is being undertaken. Thereafter, based on the findings, ministry-specific reduction targets will be set and ministries will develop and implement appropriate measures in order to reach an overall reduction objective of $25 \%$ by 2010 . Based on the assumption that the government meets reduction target the impact on growth and employment has been simulated using the TAXLAB model of the IHS (see BOX 2 and ANNEX). The results indicate

\footnotetext{
${ }^{77}$ Fo.FO.S, SELF-EMPLOYMENT, ongoing research project, http://www.fofos.at/downloads/4497116814e5b.pdf.
} 
that this measure may result in a sustained increase in real GDP by $0.75 \%$ and the creation of additional 12,000 jobs.

The Austrian Code of Corporate Governance, established in 2002 and applicable to Austrian stock exchange listed companies, provides corporations with a comprehensive framework for management and control. Based on Austrian corporation law, securities law and capital market law, EU recommendations and principles set out in the OECD Principles of Corporate Governance, the code aims to establish a system of management and control for companies and groups that is accountable and sustainable, long-term value. Since the proportion of Austrian stock listed companies in 2005 amounted to $0.5 \%$ of all enterprises, growth effects of this code can only be very small.

The Bundesvergabegesetz 2006 tries to improve the functioning of the internal market which will enable the EU to reap full benefits from such enlarged market place. Public procurement, a key strategic sector in the EU economy, accounts for approximately $16 \%$ of the average EU GDP. With public procurement amounting to $16,46 \%$ of GDP, Austria is within the EU average.

\section{Conclusion:}

As SMEs are the backbone of the European economy, targeted measures for SMEs are highly important. The initiatives for creating a competitive business environment and encouraging private initiative through better regulation promise positive effects in accordance with the Lisbon Strategy.

The Austrian government is addressing issues such as cost of financing, taxation of SMEs and administrative barriers, which seems to correspond to the problems perceived by firms and relevant enterprise-peer group(s). Adequate measures for handling the situation are being prepared and implemented. 
Table 18: Capital and Reserves of SMEs

Table 3.1: Capital and reserves (equity), by sector, enterprise size, and country, 2000, percentage of total capital

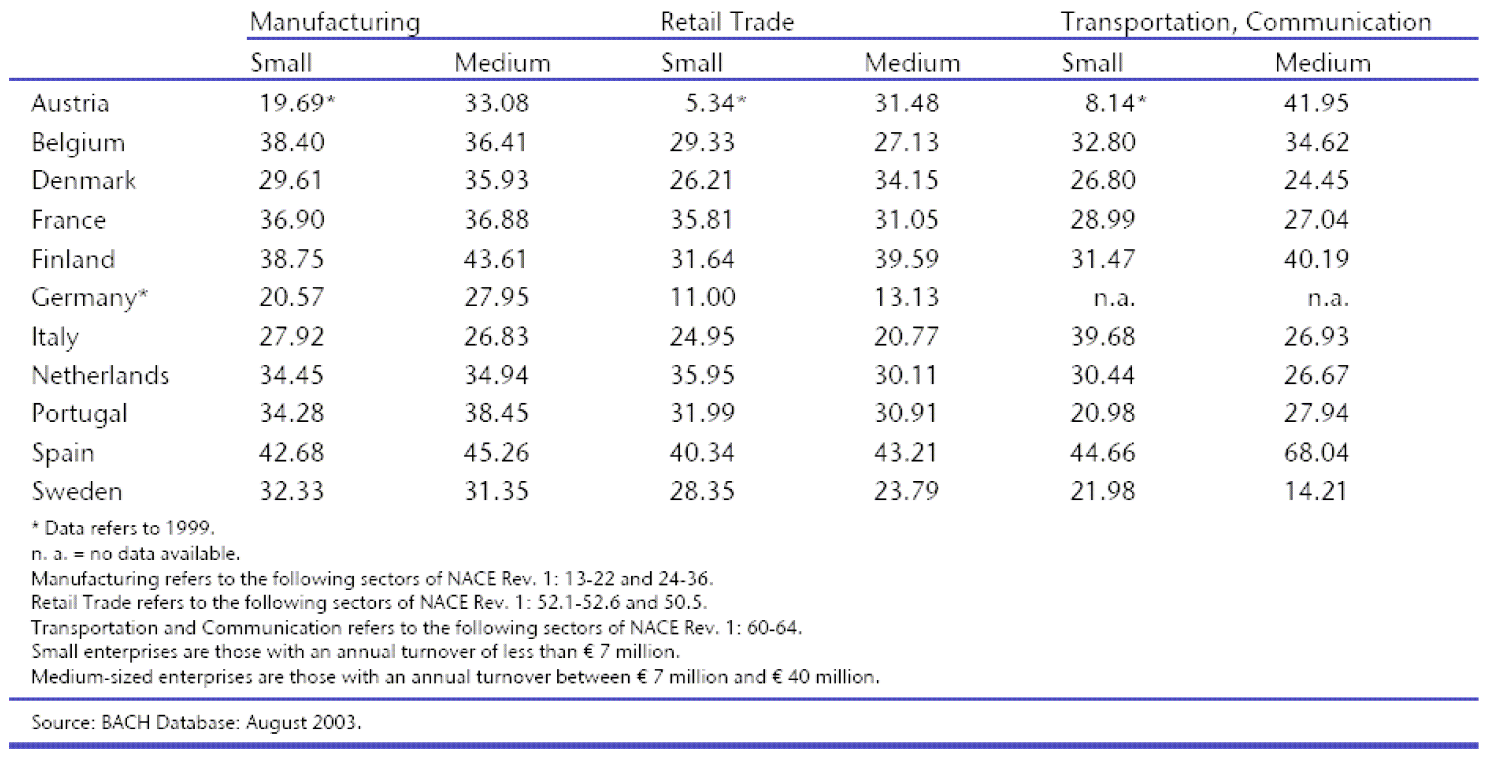

Source: European Commission, Observatory of European SMEs 2003, No. 2, in:

http://ec.europa.eu/enterprise/enterprise policy/analysis/doc/smes observatory 2003 report2 en.pdf

Figure 21: Relevance of Small Enterprises and Start-Ups (2005)

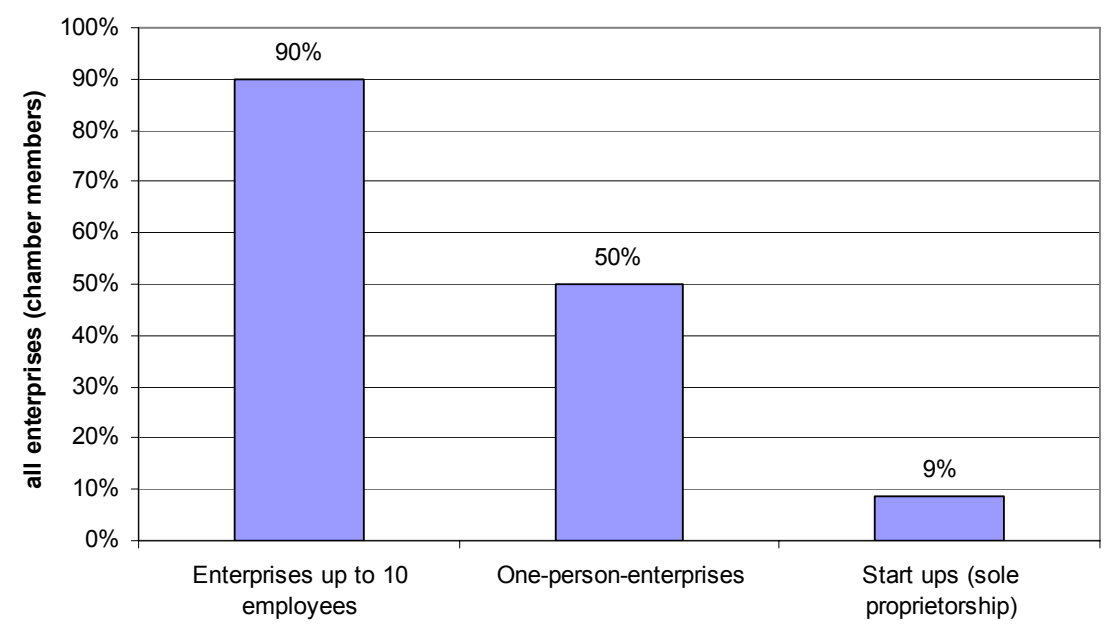

Source: WKÖ, IHS 
Table 19: Relevance of Small Enterprises and Start-Ups (2005)

\begin{tabular}{|lrr|}
\hline Members of WKO (One-person-enterprises, Microenterprises) & $\mathbf{2 0 0 5}$ \\
\hline Enterprises up to 10 employees (size group) & 269.155 \\
Employees & $\%$ of all enterprises & $90 \%$ \\
& & 356.068 \\
One-person-enterprises & $\%$ of all employees & $17 \%$ \\
& & 149.595 \\
Start ups (sole proprietorship) & \% of all enterprises & $50 \%$ \\
& & 25.812 \\
Medium term effect on employment - start-ups of all enterprises & $9 \%$ \\
\multicolumn{2}{|c}{$\%$ of all employees (2005) } & 61.489 \\
& $21 \%$ \\
\hline
\end{tabular}

Source: WKÖ, IHS.

Figure 22: Potential Employment Effects of Small Enterprises and Start-Ups (2005)

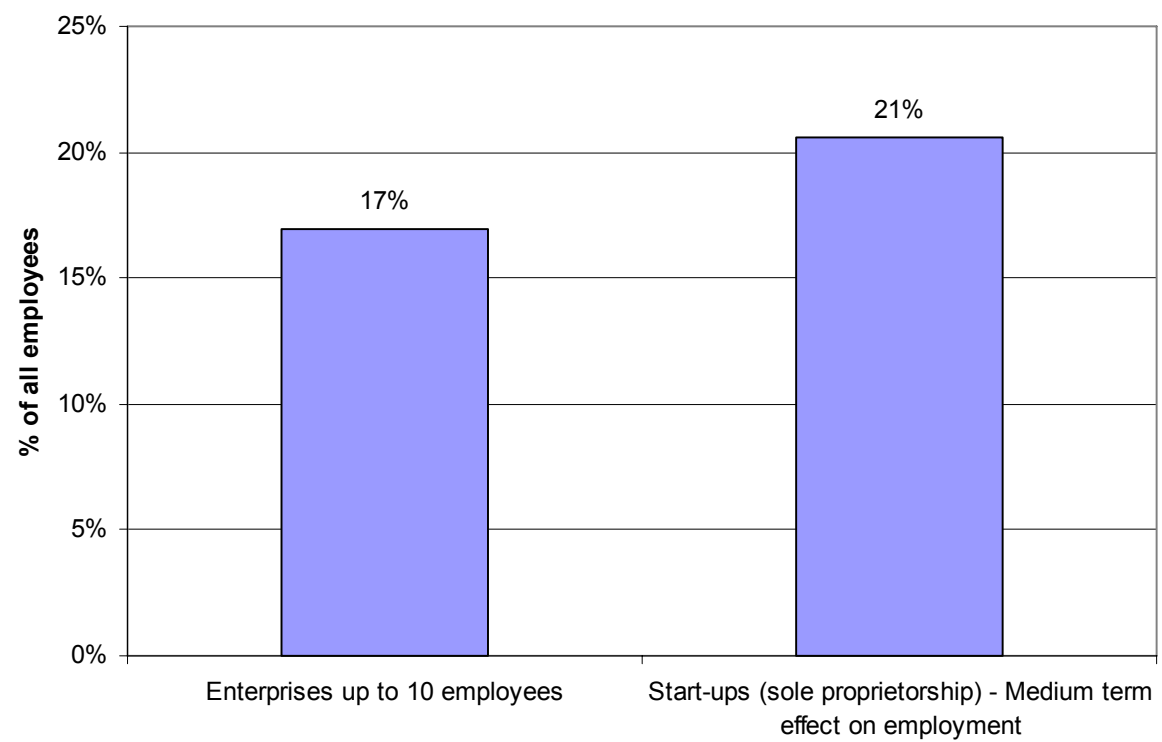

Source: WKÖ, IHS. 
Table 20: Chamber of Commerce Members by legal form of enterprise (Austria 2005)

15.1 Chamber members by legal form 2005

\begin{tabular}{l|r|r|r|r|r}
\hline \multirow{2}{*}{ legal form } & \multicolumn{2}{|c|}{ active members } & \multicolumn{2}{c|}{ inactive } & \multicolumn{2}{c}{ total members } \\
\cline { 2 - 6 } & number & \multicolumn{1}{c|}{$\%$} & number & number & \multicolumn{1}{c}{$\%$} \\
\hline Sole proprietorship & 250,925 & 70.1 & 92,120 & 343,045 & 75.1 \\
$\quad$ off record & 247,965 & 69.3 & 91,736 & 339,701 & 74.4 \\
$\quad$ on record & 2,960 & 0.8 & 384 & 3,344 & 0.7 \\
\hline Limited company (Ges.m.b.H) & 68,905 & 19.3 & 3,012 & 71,917 & 15.8 \\
\hline Kommandit-Erwerbsgesellschaft (KEG) & 12,576 & 3.5 & 1,522 & 14,098 & 3.1 \\
Kommanditgesellschaft (KG) & 10,498 & 2.9 & 347 & 10,845 & 2.4 \\
\hline Offene Erwerbsgesellschaft (OEG) & 6,446 & 1.8 & 655 & 7,101 & 1.6 \\
\hline Association (Verein) & 2,937 & 0.8 & 562 & 3,499 & 0.8 \\
\hline Public company (AG) & 1,796 & 0.5 & 51 & 1,847 & 0.4 \\
\hline Offene Handelsgesellschaft (OHG) & 921 & 0.3 & 81 & 1,002 & 0.2 \\
\hline Erwerbs- und & 989 & 0.3 & 24 & 1,013 & 0.2 \\
Wirtschaftsgenossenschaften & 801 & 0.2 & 155 & 956 & 0.2 \\
\hline GesmbH\&CoKG & 559 & 0.2 & 25 & 584 & 0.1 \\
\hline Foreign legal form & 180 & 0.1 & 62 & 242 & 0.1 \\
\hline (Nicht) prot. Untern. jurist. Pers. & 323 & 0.1 & 55 & 378 & 0.1 \\
\hline Other legal forms & 357,856 & 100.0 & 98,671 & 456,527 & 100.0 \\
\hline TOTAL & & & \\
\hline
\end{tabular}

${ }^{1}$ multiple counting in case of membership in more than one province

Source: http://wko.at/statistik/jahrbuch/2006 kap15 de.pdf

Table 21: Start ups of enterprises by legal form (Austria 2000-2005)

17. 1 Start-ups of enterprises ${ }^{1}$ by legal form

\begin{tabular}{l|r|r|r|r|r|r}
\hline \multirow{2}{*}{ legal form } & \multicolumn{7}{|c|}{2000} & \multicolumn{7}{|c|}{ number } \\
\cline { 2 - 7 } & \multicolumn{7}{|c|}{2001} & \multicolumn{1}{c|}{2002} & 2004 & $2005^{2}$ \\
\hline Sole proprietorship & 18,295 & 20,197 & 19,939 & 22,601 & 23,898 & 25,812 \\
(off record) & 3,028 & 3,312 & 3,285 & 3,089 & 3,294 & 3,493 \\
Limited company (GmbH) & 1,149 & 1,239 & 1,313 & 1,305 & 1,322 & 1,161 \\
KEG & 861 & 830 & 875 & 820 & 768 & 731 \\
OEG & 157 & 160 & 168 & 185 & 192 & 96 \\
KG, GmbH \& Co KG & 100 & 96 & 88 & 131 & 109 & 135 \\
Association (Verein) & 58 & 70 & 39 & 31 & 30 & 27 \\
Public company (AG) & 23 & 30 & 20 & 29 & 10 & 14 \\
Sole proprietorship & 22 & 34 & 24 & 29 & 24 & 13 \\
(on record) & 69 & 67 & 77 & 102 & 93 & 143 \\
OHG & 23,762 & 26,035 & 25,828 & 28,322 & 29,740 & 31,625 \\
Other legal forms & & & & 0 \\
TOTAL
\end{tabular}

Start-ups of enterprises within the Economic Chambers

2 provisional data

Source: $\underline{\text { http://wko.at/statistik/jahrbuch/2006 kap17 de.pdf }}$ 
Table 22: Quarterly Report (1/2006) of the Austrian Wirtschaftsservice

\begin{tabular}{|c|c|c|c|c|c|c|c|c|c|}
\hline & \multicolumn{2}{|c|}{$\begin{array}{l}\text { Number of } \\
\text { subsidies }\end{array}$} & \multicolumn{2}{|c|}{$\begin{array}{l}\text { Aggregated } \\
\text { effects } \\
\text { Mio. EUR }\end{array}$} & \multicolumn{2}{|c|}{$\begin{array}{l}\text { Subsidies total } \\
\text { Mio. EUR }\end{array}$} & \multicolumn{3}{|c|}{ Jobs } \\
\hline & $1 / 06$ & 2005 & $1 / 06$ & 2005 & $1 / 06$ & 2005 & created & saved & total \\
\hline $\begin{array}{l}\text { Liabilities according the } \\
\text { recent SME-initiative of the } \\
\text { Austrian government }\end{array}$ & 220 & 884 & 42,1 & 149,8 & 26,9 & 101,7 & 454 & 1395 & 1849 \\
\hline \multicolumn{10}{|l|}{ Important measurements: } \\
\hline "Double Equity" & 24 & 98 & 7,1 & 30,2 & 6,1 & 26,9 & 154 & 148 & 302 \\
\hline "Jununternehmerförderung" & 99 & 410 & 6,4 & 24,3 & 4,2 & 16,5 & 120 & 77 & 197 \\
\hline "Unternehmensdynamik" & 60 & 238 & 19,7 & 73,1 & 11 & 43,3 & 157 & 704 & 861 \\
\hline
\end{tabular}

Source: AWS.

Table 23: Functioning of the public procurement markets in the $\mathrm{EU}^{78}$

\begin{tabular}{|lcccccccr|}
\hline Table 1 & \multicolumn{7}{c|}{ Total Procurement as a Percentage of GDP } \\
\hline & 1995 & 1996 & 1997 & 1998 & 1999 & 2000 & 2001 & 2002 \\
\hline Belgium & 14,38 & 14,61 & 14,35 & 14,37 & 14,69 & 14,75 & 14,91 & 15,22 \\
Denmark & 16,27 & 16,26 & 16,51 & 16,94 & 17,26 & 17,39 & 18,40 & 18,76 \\
Germany & 17,98 & 17,99 & 17,45 & 17,19 & 17,15 & 16,99 & 17,01 & 17,03 \\
Greece & 13,62 & 12,92 & 12,69 & 13,00 & 12,71 & 13,55 & 12,98 & 12,62 \\
Spain & 13,84 & 12,81 & 12,76 & 12,97 & 12,94 & 12,73 & 12,75 & 13,02 \\
France & 17,26 & 17,32 & 17,26 & 16,49 & 16,35 & 16,52 & 16,35 & 16,62 \\
Ireland & 13,54 & 12,87 & 12,11 & 11,95 & 12,05 & 12,23 & 13,25 & 13,30 \\
Italy & 12,58 & 12,17 & 12,00 & 12,12 & 12,25 & 12,37 & 12,69 & 11,88 \\
Luxembourg & 15,49 & 16,01 & 14,89 & 14,43 & 14,38 & 13,11 & 14,25 & 15,48 \\
Netherlands & 20,84 & 20,51 & 20,27 & 20,12 & 20,21 & 20,12 & 20,68 & 21,46 \\
Austria & 18,36 & 18,15 & 17,70 & 17,69 & 17,77 & 17,05 & 16,22 & 16,46 \\
Portugal & 14,14 & 14,56 & 14,57 & 13,85 & 14,29 & 13,98 & 13,91 & 13,26 \\
Finland & 16,25 & 16,70 & 16,57 & 15,96 & 16,06 & 15,37 & 15,72 & 16,45 \\
Sweden & 22,14 & 20,97 & 19,99 & 20,48 & 20,27 & 19,40 & 20,01 & 20,49 \\
UK & 21,68 & 20,58 & 18,24 & 17,79 & 17,84 & 17,46 & 17,89 & 18,42 \\
EU 15 & $\mathbf{1 7 , 2 6}$ & $\mathbf{1 6 , 8 9}$ & $\mathbf{1 6 , 3 3}$ & $\mathbf{1 6 , 1 0}$ & $\mathbf{1 6 , 1 3}$ & $\mathbf{1 6 , 0 2}$ & $\mathbf{1 6 , 1 8}$ & $\mathbf{1 6 , 3 0}$ \\
\hline
\end{tabular}

Source: Internal Market Directorate General

\footnotetext{
${ }^{78} \mathrm{~A}$ report on the functioning of public procurement markets in the EU: benefits from the application of EU directives and challenges for the future 03/02/2004, p. 5. http://ec.europa.eu/internal market/publicprocurement/docs/publicproc-market-final-report en.pdf.
} 


\section{BOX 2: Simulation of a reduction of regulation costs (by TAXLAB, see ANNEX)}

The model simulation of reduced regulation costs of businesses is based on some assumptions. Basis of our simulation is an investigation of the administration of the Netherlands. ${ }^{79}$ We assume that regulation costs in Austria correspond to the structure of the system in the Netherlands. In the simulation it is assumed that the total amount of regulation costs in Austria is 8 billion $€$ and the aim of reduction accounts for $25 \%$, which means a reduction of 2 billion $€$. We assume further, that some of the reduction lowers only leisure time of employers or are independent of output or factor input (lump-sum costs), some reduces costs measured by value added and some reduces the time employees work on providing information for the administration. The division into the three groups is shown in Table 24 and also crucial for the results, meaning that displacements between these groups have an important impact.

Table 24: Division of regulation costs on different categories

\begin{tabular}{|c|c|c|c|}
\hline & Lump-Sum & Value added & Labour costs \\
\hline Percentage & $46 \%$ & $36.5 \%$ & $17.5 \%$ \\
\hline
\end{tabular}

Effects on growth and employment come on the one hand from reduced production costs, letting input factor price relations unchanged, and more effective labour input on the other hand. The lump sum component lets price relations unchanged and leads to no growth or employment effect. Using the division of business administration costs the general equilibrium model TAXLAB leads to long-run results presented in the first column of Table 25. Some kind of sensitivity analysis is done by varying the composition of the regulation costs. The results of this analysis are shown in the following columns of Table 25. The first number in each column represents the lump sum, the second the value added and the third one the labour cost share of the decrease of the regulation costs.

Table 25: Growth and Employment effects of the reduction of regulation costs

\begin{tabular}{|l|c|c|c|c|}
\hline Model results - & $\mathbf{4 6 \%}$ & $\mathbf{6 0} \%$ & $\mathbf{3 0} \%$ & $\mathbf{4 6} \%$ \\
long term & $\mathbf{3 6 . 5} \%$ & $\mathbf{2 7} \%$ & $\mathbf{4 7 . 5} \%$ & $\mathbf{2 7} \%$ \\
& $\mathbf{1 7 . 5} \%$ & $\mathbf{1 3} \%$ & $\mathbf{2 2 . 5} \%$ & $\mathbf{2 7} \%$ \\
\hline \hline GDP & $0.74 \%$ & $0.54 \%$ & $0.95 \%$ & $0.84 \%$ \\
Labour input & $0.44 \%$ & $0.33 \%$ & $0.57 \%$ & $0.46 \%$ \\
Additional jobs & 12,126 & 8,937 & 15,646 & 12,617 \\
Investment & $0.98 \%$ & $0.72 \%$ & $1.27 \%$ & $1.02 \%$ \\
\hline
\end{tabular}

Source: Simulations with TAXLAB (see ANNEX)

\footnotetext{
${ }^{79}$ See Ministry of Finance (2005), p. 7 ff.
} 
Growth effects occur due to the following reasons. Reducing value added costs increases output per unit of labour and capital. This increases on the one hand the wage and therefore labour supply and on the other hand the productivity of capital. The latter point leads to further capital accumulation and growth. The reduction of the labour costs increases output per worker which rises labour demand. This leads to further capital accumulation and higher wages. The lump-sum component leaves growth and employment unchanged, but increases the profits of the firms. 


\subsection{Environmental technologies and efficient resource management}

\section{Summary}

As the Lisbon Strategy aims at a sustainable increase in the growth potential of member states closer attention has to be given to the environmental implications of the economic growth in the medium to long term. According to endogenous growth theory, economic growth is sustainable if new technologies decrease the pollution per economic output ratio. The priority of initiatives in the field environmental consequently is to reconcile economic growth with environmental conditions.

The development, implementation and use of environmental technologies may, however, also generate positive growth and employment effects. According to endogenous growth theory and studies on environmental industry, investment in environment technologies has a high value added, creates jobs and contributes to exports and the substitution of imported fossil energy by domestic renewable energy.

Environmental industry, including modern "clean technologies", is a growing sector in Austria and Austrian enterprises have good export positions on the international market. In its report, the European Commission approved of the Austrian coherent strategies to boost innovation and environmental technology.

The European comparative study ECOTEC supports the view that EU eco-industries create employment both in a direct and indirect way. ${ }^{80}$ Effects on employment and value added of investment in renewable energy and green electricity facilities can either be positive or negative, taking into account direct and indirect effects as well as short and long-term effects.

The share of renewable energy sources in gross domestic energy consumption in Austria increased from 1990-2003. In 2003, Austria held fourth place among EU 25 countries, with a share of around $20 \%$. In 2005, the share amounted to $22.12 \%$. In 2004, Austria was the country with the second lowest energy intensity among EU15 countries, due to the use of energy saving environmental technologies.

To obtain the net effect of investment in and operation of new green electricity installations, the positive effect on employment and value added has to be compared with the negative indirect effect resulting from the reduction of disposable income. While the positive effects of green facilities appear in the short run, negative indirect effects become visible in the long run only.

\footnotetext{
${ }^{80}$ ECOTEC Research and Consulting Ltd., "Analysis of the EU eco-industries, their employment and export potential," A Final Report to DG Environment, Birmingham, 2002.
} 
Figure 23: Effects of NRP on Economic Interactions - Environment

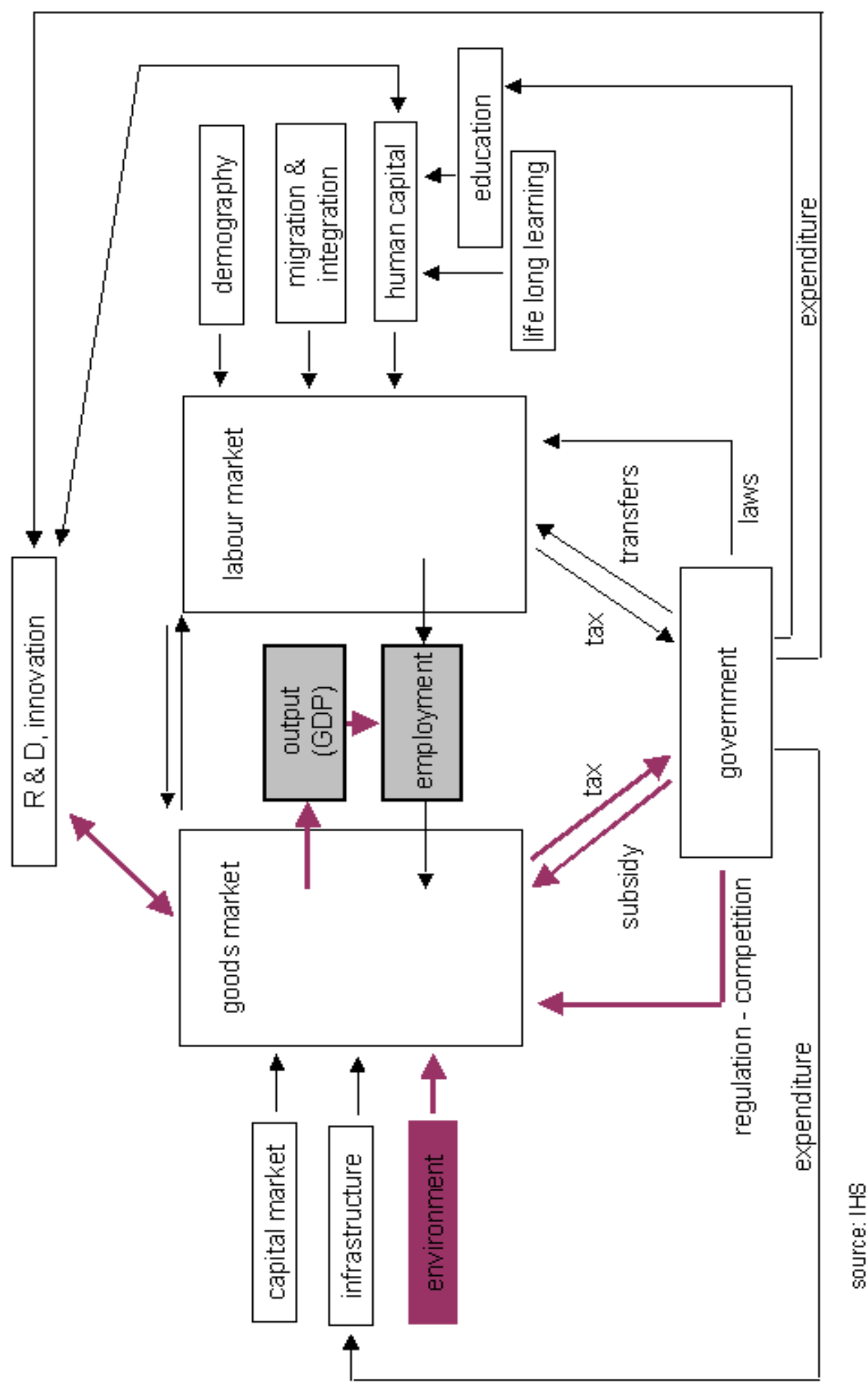




\section{Expected Effects of investment in environmental technologies}

According to endogenous growth theory, economic growth is sustainable if new technologies decrease the pollution per economic output ratio ${ }^{81}$. Environmental technologies contribute to energy efficiency and environmental protection through decoupling growth and resource intensity. Therefore, investment in innovative environmental technologies - especially in integrated "clean technologies" and facilities using renewable sources of energy - contributes to sustainable long run economic growth.

Furthermore, studies on environmental industry provide empirical evidence on growth and employment potentials in this sector. Investment in environment technologies has a high value added, creates jobs and contributes to exports and substitution of imported fossil energy by domestic renewable energy ${ }^{82}$.

The Kok report ${ }^{83}$ recognizes the development of innovative environmental technologies as crucial factor for sustainable economic development because it contributes to growth and employment as well as energy efficiency and environmental protection.

\section{Current situation and energy indicators}

Environmental industry, including modern "clean technologies", is a growing sector in Austria and Austrian enterprises have good export positions on the international market. According to empirical studies in companies, ${ }^{84}$ total turnover of the Austrian environmental industry in 2003 was estimated at 3.78 billion $€$, with an employment effect of 17,200 jobs and with environmental exports amounting to 2,45 billion $€$. Environmental industry gained importance from 1993 to 2003: While the share of environment technology turnover in manufacturing turnover rose from $2.1 \%$ to $3.7 \%$, the share of environmental industry employment in manufacturing employment increased from $2 \%$ to $3.3 \%$. The contribution of environmental technology to nominal GDP grew from $1 \%$ to $1.7 \%$.

"Clean technologies" - comprising cogeneration plants, systems engineering, plants increasing resource optimisation, biomass plants, hydropower and solar technologies,

\footnotetext{
${ }^{81}$ Aghion, P., Howitt, P., "Endogenous growth theory”, Cambridge, MA. MIT Press, 1998

${ }^{82}$ Köppl A.,"The Austrian Environmental Industry. Summary of results", WIFO, Österreichisches Institut für Wirtschaftsforschung, February 2006; ECOTEC Research and Consulting Ltd., "Analysis of the EU eco-industries, their employment and export potential", A Final Report to DG Environment, Birmingham, 2002.

${ }^{83}$ Kok W., "Die Herausforderungen Annehmen. Die Lissabon-Strategie für Wachstum und Beschäftigung. Bericht der Hochrangiger Sachverständigengruppe unter Vorsitz von Wim Kok", Luxembourg, Amt für Amtliche Veröffentlichungen der Europäischen Gemeinschaften, 2004.

${ }^{84}$ The environment industry is a cross-sectional sector. Therefore the analysis of this industry is based on inquiries in companies carried out by the WIFO in 1995 (data '93), in 2000 (data '97) and in 2005 (data '03) (Köppl, 2006).
} 
photovoltaics, heat pumps and biogas plants), ${ }^{85}$ generated turnover of 1.8 billion $€$ and 7,480 employees in 2003.

The share of renewable energy sources in gross domestic energy consumption in Austria increased from 1990-2003. Austria holds fourth place among EU 25 countries, with a share of around $20 \%$ in 2003 (Figure 24). ${ }^{86}$ This share increased to $22.12 \%$ in 2005, according to the newest data from the Austrian Federal Ministry of Agriculture, Forestry, Environment and Water Management (Table 26).

The energy intensity of the Austrian economy fluctuated from 2001 to 2004. After Denmark, Austria was the country with the lowest energy intensity among EU15 countries in 2004, which is attributed to the use of energy saving environmental technologies (Figure 25). ${ }^{87}$ The EU target for energy efficiency aims at saving potentials of $20 \%$ by $2020 .{ }^{88}$

In the field of environmental protection Austria has committed itself to the Kyoto protocol to decrease greenhouse emissions by $13 \%$ as compared to 1990. In 2004 emission levels, there is a gap of 22.6 mio t $\mathrm{CO}_{2}$ gas, which should be closed until 2010 by reductions in space heating, transport, electricity production and industry. ${ }^{89}$ Favourable conditions and incentives for the development of environmental technologies and environmental protection support emission reduction.

In its report, the European Commission ${ }^{90}$ approved of the Austrian coherent strategies to boost innovation and environmental technology. Sector specific initiatives to promote the development and implementation of environmental technologies contributing to resource efficiency and the use of renewable energy sources as well as programmes like klima:aktiv that provide financial support for climate-friendly technologies were assessed important measures to reach climate protection targets.

\section{Evaluation of NRP actions}

In general, measures in the field of environmental technologies create favourable framework conditions for promoting the development of environmental technologies and ensuring synergies between economic growth, employment and climate protection. The evaluation of

\footnotetext{
${ }^{85}$ Köppl A., 2006, Op.cit.

${ }^{86}$ according to the latest available comparative data: Eurostat, 08/2006; Statistik Austria, Yearbook 2006; information from Austrian Federal Ministry of Agriculture, Forestry, Environment and Water Management, Oct. 2006. ${ }^{87}$ Eurostat, extraction: 08/2006.

${ }^{88}$ BMLFUW, "Environmental technologies. Innovations from Austria", 2006, in: www.lebensministerium.at; European Commission, "Doing more with less. Green paper on energy efficiency", 2005, in: http://ec.europa.eu/energy.

${ }^{89}$ BMWA, Wirtschaftsbericht, 2006.

${ }^{90} \mathrm{EC}$, “Analysis of the Austrian National Reform Programme for Growth and Jobs," in: http://ec.europa.eu.
} 
the "Climate strategy" in 2005 resulted in reform and new implementation steps, ${ }^{91}$ such as a widening of environmental support (plus 90 mio. $€$ yearly) from 2006 onwards. Effects of such support depend on the concrete field of action. An example is renewable energy use in electricity production, which promotes the use of electricity from ecological sources (Green Electricity Act, 2006) to reach $10 \%$ until $2010 .^{92}$ This measure promotes investment in green electricity facilities and the substitution of fossil fuel with bio fuel (2008 target: $5.75 \%$ ), thereby reducing the dependence from imported fossil energy.

According to a study by the Institute for Advanced Studies Carinthia, the effect of investment in and operation of new green electricity installations on employment and value added is positive. Support of such investment by means of reimbursement for feed-in into the electricity grid (Einspeisevergütungen), however, contributes to higher electricity prices and additional charges for households, and therefore results in negative income withdrawal effects. To obtain the net effect of investment in and operation of new green electricity installations, the positive effect on employment and value added has to be compared with the negative indirect effect resulting from the reduction of disposable income (for an illustration of different types of employment and value added effects see Table 27, Table 28, Table 29, Table 30, Table 31, Table 32).$^{93}$

While the positive direct and indirect effects of green facilities appear in the short run, negative indirect effects become visible in the long run only. Moreover, the higher price of green electricity can have negative cost and competitiveness effects and create barriers for domestic investment. On the other hand, the support of renewable energy can create learning curve effects contributing to effectiveness and price reductions of the green electricity production and thus reducing disposable income, negative cost and competitiveness effects. Moreover, according to the "lead market hypothesis", the support of renewable energy as a key technology for competitive advantage on international market contributes to positive employment and value added effects. ${ }^{94}$

Austria possesses all prerequisites for the deployment of technologies using renewable energy sources. It has the highest share of all renewable energy sources (including hydropower) in EU 25 electricity production (Figure 26 and Table 33; for an illustration of solar technologies see Table 34).

\footnotetext{
${ }^{91}$ Wirtschaftsbericht, 2006, Op.cit.

${ }^{92}$ Note: other green electricity: from biomass, biogas, wind, solar-thermal energy, geothermal energy; Beschluss des Nationalrates, Ökostromgesetz-Novelle 2006, 655 der Beilagen XXII. GP, 2006.

93 Energie-Control $\mathrm{GmbH}$, "Bericht über die Ökostrom-Entwicklung und fossile Kraft-Wärme-Kopplung in Österreich“, gemäß $\S 25$ Abs 1 Ökostromgesetz (BGBI I Nr 149/2002)“ zur Vorlage beim Bundesminister für Wirtschaft und Arbeit und beim Elektrizitätsbeirat, Juni 2005 mit Ergänzung der Halbjahresdaten 2005 im August 2005, in: http://www.e-control.at; Bodenhöfer H., et al., "Bewertung der volkswirtschaftlichen Auswirkungen der Unterstützung von Ökostrom in Österreich", Institut für Höhere Studien Kärnten, Klagenfurt, Juli 2004.

${ }^{94}$ Häder M., Schulz E., "Renerative Energien”, Energiewirtschaftliche Tagesfragen, Vol. 7, 2005.
} 
The NRP actions "emissions' trade", "joint implementation" (JI), "clean development mechanism" (CDM) and "assigned amount units" ( $A A U)$ contribute to the implementation of the climate strategy. The volume of emission certificates reached the scarcity of rights, which ensured the functioning of a competitive emission market. This contributes to the internalisation of the external cost of $\mathrm{CO}_{2}$ emission, since incentives for cost-efficient emission reduction allows companies to realize competitive advantages at the same time as achieving resource efficiency, climate protection and economic benefits.

The competitiveness of green electricity production increases in comparison to conventional electrical production and the support of green electricity facilities will contribute to the overall reduction of $\mathrm{CO}_{2}$ emissions, thereby lowering the demand for emission certificates and thus their market price. Yet, the assigning volume of emission certificates should decrease with the attainment of climate protection targets, which will in turn increase the market price of emission certificates. ${ }^{95}$ Expected effects are medium and long run.

Purchase of emission reduction certificates through participation in international projects with innovative environmental technologies: Investment in and export of Austrian technologies and related know-how to transformation and development countries are a cost-efficient way to receive $\mathrm{CO}_{2}$ reduction certificates. ${ }^{96}$ The Austrian competitive advantage in environmental technology will have positive economic effects related to growth both in Austria and the recipient countries. Employment effects depend on the skill levels of employees. ${ }^{97}$

The "Environmental Technologies Action Plan" (ETAP) ${ }^{98}$ supports development and diffusion of environmental technologies. This includes basic and applied research, as well as production and market realisation activities. Although most funds still go into basic research, applied and demonstration projects and the involvement of enterprises were promoted more intensively in the last years. In addition to research support an EU-wide meta-database and performance targets in production process are in process of development. ETAP supports, by means of the Austrian federal guarantee instrument of the "Austrian Wirtschaftservice", investment in innovative environmental technology.

\footnotetext{
${ }^{95}$ Bodenhöfer H., et al., 2004, Op.cit.

${ }^{96}$ Wirtschaftsbericht, 2006, Op. cit.; BMLFUW, „Das Österreichische Joint-Implementation- und Clean-Development-Mechanism (JI/CDM) - Programm“; BMLFUW, „Österreichs JI/CDM-Programm 2005 Joint-Implementation/Clean-Development-Mechanism-Programm, in: http://www.ji-cdm-austria.at.

${ }^{97}$ Vernon, R., "International Investment and International Trade in the Product Cycle", Quarterly Journal of Economics, 80 (2), 1966, pp. 190-210; Dunning J. H., "Explaining Changing Patterns of International Production: In Defence of the Eclectic Theory", Oxford Bulletin of Economics and Statistics, 41, 1979, pp. 269-295; Ekholm, K., "Industrial Structure and Industry location in an Enlarged Europe," Swedish Institute for European Policy Studies, 2003.

${ }_{98}$ BMLFUW, “ETAP Roadmap 2005”, 2005, in: www.lebensministerium.at; BMWA, „Österreichisches Reformprogramm für Wachstum und Beschäftigung“ (NRP), Wien, 2006.
} 
A common approach for funding of environmental and R\&D projects was adopted and from 2002 to 2004, 2,467 projects were funded with a total sum 140.7 Mio. $€$, which increased the investment volume of environmental actions to 679,4 Mio. $€ .{ }^{99}$ ETAP also fosters the market realisation of innovative environmental technologies through klima:aktiv target group programmes in the sectors of building and energy saving, transport, communities and renewable energy.

The environmental technologies export initiative is set out to boost the competitive strengths of Austrian companies, especially SMEs, and to create exports and investment incentives for Austrian environmental technologies on foreign markets. Taking into account the growing potential of the Austrian environmental industry, support of environmental technologies contributes to positive growth and employment effects (Table 35). ${ }^{100}$

The introduction of ecological considerations into public procurement adjusts public financial support to projects dealing with environmental issues. Another focus on energy and resource efficiency promotes the decoupling of economic growth and resource/energy intensity with the aim to ensure sustainable development. ${ }^{101}$

"Increasing energy efficiency" promotes declining energy consumption through the realisation of economic growth. The energy intensity of the Austrian economy was reduced by $27 \%$ between 1973 and 2004. Concerning industrial sectors, there seems to be a positive tendency of divergence between fuel consumption and $\mathrm{CO}_{2}$ emissions and industrial production development. The later increased from 1998 to 2004 with a higher rate indicating a relative decoupling of industrial production from resource intensity. ${ }^{102}$ Energy efficiency will further be promoted in households and the service sector.

The "Action plan for increasing the resource efficiency of the Austrian economy" is part of the climate strategy. It is in line with the accomplishment of EU targets concerning energy efficiency. ${ }^{103}$ The plan aims at contributing to sustainable development, to long-term high quality jobs by compensating for market failures in the sustainable use of resources and encouraging innovative technology sectors.

"Ecological considerations in the tax system" promotes greenhouse emission reductions by lower consumption of fossil fuel, as well as an increase of bio fuel/particle filters use. This

\footnotetext{
${ }^{99}$ BMLFUW, "ETAP Roadmap 2005," 2005, in: www.lebensministerium.at .

${ }^{100}$ Köppl A.,"The Austrian Environmental Industry. Summary of results”, WIFO, Österreichisches Institut für Wirtschaftsforschung, February 2006; ECOTEC Research and Consulting Ltd., "Analysis of the EU eco-industries, their employment and export potential", A Final Report to DG Environment, Birmingham, 2002.

101 „Die österreichische Strategie zur Nachhaltigen Entwicklung“. Initiative des Bundesregierung, in: http://www.nachhaltigkeit.at/strategie/pdf/strategie020709 de.pdf.

102 Umweltbundesamt, „Kyoto-Fortschrittsbericht Österreich 1990-2004“, Wien, 2006, in: www.umweltbundesamt.at.

${ }^{103}$ BMLFUW, "Environmental technologies - Innovations from Austria", 2006, in: in: www.lebensministerium.at.
} 
action relates to the achievement of a revenue neutral ecological tax reform with parallel tax exonerations for the factor labour - exonerations of older employees and additional increase of tax free limits. ${ }^{104}$ Further exonerations or tax concessions to stimulate the use of bio fuels are under consideration. Target groups/sectors are transport, industry, households (energy costs) and employees. The measure also contributes to the correction of market failure (internalisation of external costs) and budgetary sustainability.

According to economic literature, the introduction of ecological taxes and the reduction of taxes related to labour have in general a "double dividend" effect - providing environmental protection and employment creation at the same time. With different models, various effects can be calculated, depending on the concrete tax mix. ${ }^{105}$ For example, possible effects of $\mathrm{CO}_{2}$-energy tax with cuts in social security contributions are estimated at $0.5 \% .{ }^{106}$ Effects on employment are smaller if income tax is decreased. ${ }^{107}$

\section{Summary of expected effects}

Environmental technology investment is expected to have a positive effect on GDP and employment. According to empirical studies, the Austrian environmental industry is a growing sector: environmental industry employment in manufacturing employment increased from $2 \%$ to $3.3 \%$ (1993-2003) and the contribution of environmental technology to nominal GDP increased from $1 \%$ in 1993 to $1.7 \%$ in $2003 .{ }^{108}$

The European comparative study ECOTEC supports the view that EU eco-industries create employment both in a direct and indirect way. ${ }^{109}$ Effects on employment and value added of investment in renewable energy and green electricity facilities can either be positive or negative, taking into account direct and indirect effects as well as short and long-term effects.

Positive short run effects on employment and value added come from investment in and the operation of new green electricity installations. Negative effects of highly subsidised investment, related to high price of green electricity, affect long run income, cost and competitiveness. The latter effects are related to the reduction of disposable income for

\footnotetext{
${ }^{104}$ BMWA, Wirtschaftsbericht, 2006.

${ }^{105}$ Heady C.J. et al. "Study on the relationship between environmental/energy taxation and employment creation", Report for the European Commission, University of Bath, April 2000; Luptacik M., Weiss Ch., Vorstudie: "Produktivität und Ökoeffizienz", Wirtschaftsuniversität Wien, 10 Jänner 2005; OECD, "Greening tax mixes in OECD countries: a preliminary assessment", 2000.

${ }^{106}$ European Commission, "Taxation, Employment and Environment: Fiscal Reform to reducing unemployment", Brussels, 2003,cited from Luptacik M., Weiss Ch., Vorstudie: "Produktivität und Ökoeffizienz", Wirtschaftsuniversität Wien, 10 Jänner 2005.

${ }^{107}$ Luptacik M., Weiss Ch., 2005, Op.cit.

${ }^{108}$ Köppl A., "The Austrian Environmental Industry. Summary of results", WIFO, Österreichisches Institut für Wirtschaftsforschung, February 2006.

${ }^{109}$ ECOTEC Research and Consulting Ltd., "Analysis of the EU eco-industries, their employment and export potential”, A Final Report to DG Environment, Birmingham, 2002.
} 
consumption in other areas and thus the reduction of induced employment and value added in these areas, as well as to barrier for investment on the internal market. However, these negative effects can be offset by positive long-term effects on employment and value added due to technical progress and competitiveness of the green electricity technologies on external market. ${ }^{110}$

Achieving competitiveness without subsidies, will contribute to the reduction of negative income withdrawal effects and negative cost and competitiveness effects of green electricity. This process could be supported by actions such as emissions trade. Positive long run effects obtained by the competitive advantages of the domestic green electricity technologies on the international market ${ }^{111}$ can be stimulated by export initiatives within ETAP and participation in international projects.

Revenue neutral ecological reforms contribute to the correction of market failure (internalisation of external costs) and to budgetary sustainability. According to economic literature, the introduction of ecological taxes and the reduction of taxes related to the labour have in general a "double dividend" effect - environmental protection and positive employment effects. These effects depend on the concrete tax mixes and applied model. Possible effects of $\mathrm{CO}_{2}$ energy tax with cuts in social security contributions, for example, are estimated at $0.5 \%$. The effect on employment is smaller if income taxes decrease.

The NRP actions regarding energy/resource efficiency promote the decoupling of economic growth and energy intensity, application of innovative environmental technologies and thus contribute to sustainable development.

Table 26: Share of renewable energy in gross domestic energy consumption, Austria

\begin{tabular}{|l|c|c|c|c|c|c|c|}
\hline & $\mathbf{1 9 9 9}$ & $\mathbf{2 0 0 0}$ & $\mathbf{2 0 0 1}$ & $\mathbf{2 0 0 2}$ & $\mathbf{2 0 0 3}$ & $\mathbf{2 0 0 4}$ & $\mathbf{2 0 0 5}$ \\
\hline Space heating & $0.56 \%$ & $0.61 \%$ & $0.54 \%$ & $0.58 \%$ & $0.58 \%$ & $0.66 \%$ & $0.63 \%$ \\
\hline Bio fuel & $4.78 \%$ & $4.87 \%$ & $5.19 \%$ & $5.31 \%$ & $5.37 \%$ & $5.69 \%$ & $6.35 \%$ \\
\hline Wood & $5.37 \%$ & $4.81 \%$ & $4.99 \%$ & $4.63 \%$ & $4.59 \%$ & $4.34 \%$ & $4.40 \%$ \\
\hline Wind/PV & $0.02 \%$ & $0.02 \%$ & $0.05 \%$ & $0.06 \%$ & $0.10 \%$ & $0.24 \%$ & $0.33 \%$ \\
\hline Hydro power & $\mathbf{1 1 . 8 7 \%}$ & $\mathbf{1 2 . 3 6} \%$ & $\mathbf{1 1 . 1 9} \%$ & $\mathbf{1 0 . 9 6 \%}$ & $\mathbf{8 . 5 0} \%$ & $\mathbf{9 . 3 8} \%$ & $\mathbf{8 . 8 8 \%}$ \\
\hline Combustible waste & $1.15 \%$ & $0.85 \%$ & $1.12 \%$ & $1.26 \%$ & $1.31 \%$ & $1.62 \%$ & $1.53 \%$ \\
\hline Sum & $\mathbf{2 3 . 7 4} \%$ & $\mathbf{2 3 . 5 2} \%$ & $\mathbf{2 3 . 0 8} \%$ & $\mathbf{2 2 . 7 9} \%$ & $\mathbf{2 0 . 4 5 \%}$ & $\mathbf{2 1 . 9 4 \%}$ & $\mathbf{2 2 . 1 2} \%$ \\
\hline
\end{tabular}

Note: space heating: solar collectors, heat pump, geothermy; sum biomass = bio fuel + wood + combustible waste. Source: Statistik Austria (11/2005), data from Austrian Federal Ministry of Agriculture, Forestry, Environment and Water Management, Dep. V/10, Leader: Dr. M. Schuster, state as of 18.8.2006, contact: Mag. A. Blaser, Oct. 2006.

\footnotetext{
${ }^{110}$ Energie-Control $\mathrm{GmbH}$, "Bericht über die Ökostrom-Entwicklung und fossile Kraft-Wärme-Kopplung in Österreich“, gemäß § 25 Abs 1 Ökostromgesetz (BGBI I Nr 149/2002)“ zur Vorlage beim Bundesminister für Wirtschaft und Arbeit und beim Elektrizitätsbeirat, Juni 2005 mit Ergänzung der Halbjahresdaten 2005 im August 2005, http://www.e-control.at; Bodenhöfer H., et al., "Bewertung der volkswirtschaftlichen Auswirkungen der Unterstützung von Ökostrom in Österreich”, Institut für Höhere Studien Kärnten, Klagenfurt, Juli 2004; Häder M., Schulz E., "Renerative Energien", Energiewirtschaftliche Tagesfragen, Vol. 7, 2005.

${ }^{111}$ Häder M., Schulz E., 2005, Op.cit.
} 
Figure 24: Share of renewable energy in gross domestic energy consumption, 2003

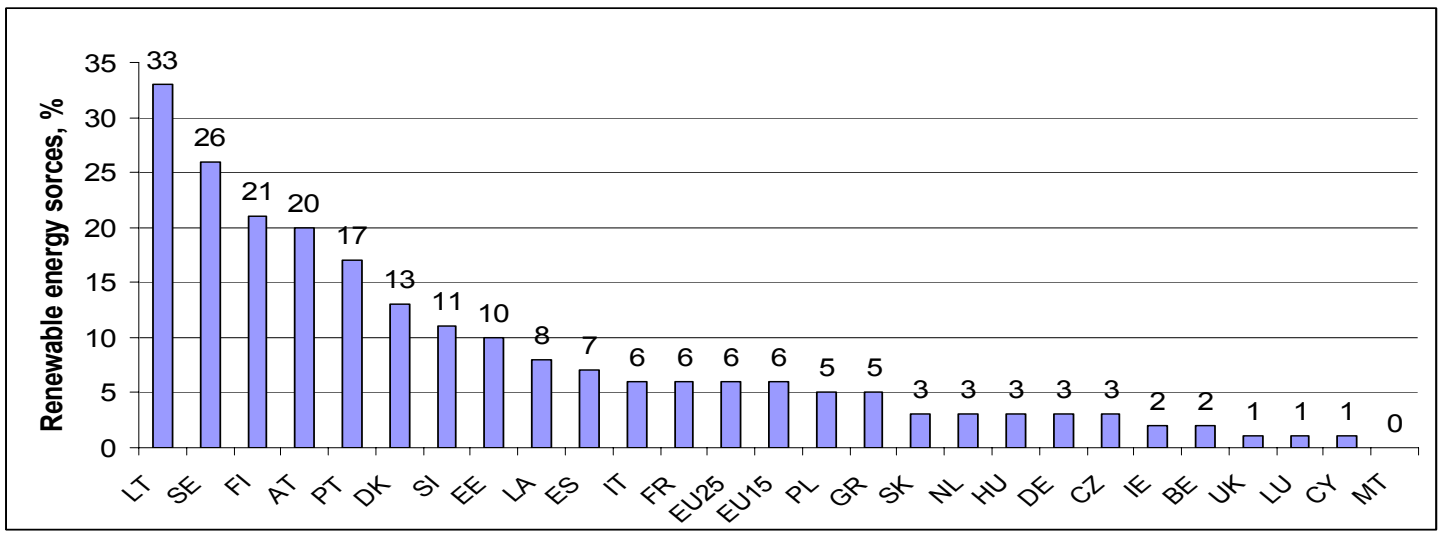

Source: Eurostat, data received from Data from Austrian Federal Ministry of Agriculture, Forestry, Environment and Water Management, Dep. V/10, Leader: Dr. M. Schuster, state as of 18.8.2006, contact: Mag. A. Blaser, Oct. 2006.

Figure 25: Energy intensity of the economy, 2004

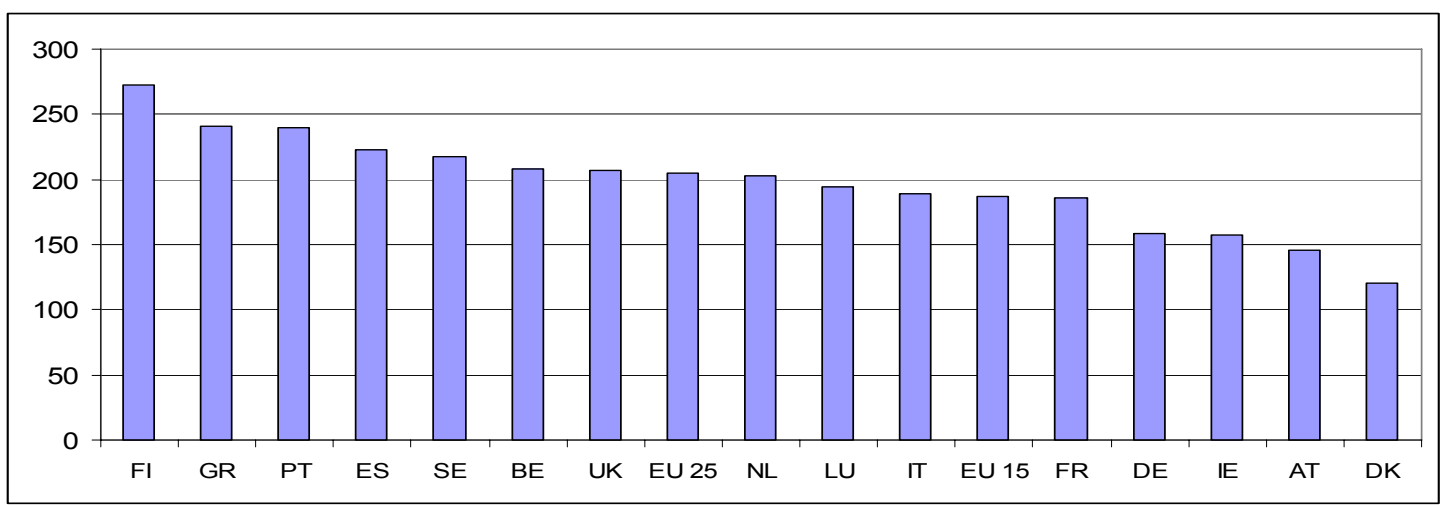

Source: Eurostat, 08/2006, Energy intensity of the economy - gross domestic consumption of energy divided by GDP (constant prices, 1995=100) - kg crude oil per $1000 €$.

Table 27: Employment and income withdrawal effects of investment in facilities using renewable energy, Austria (typical case studies 2005, representative for major part of granted green electricity installations in the last 2 years)

\begin{tabular}{|l|c|c|c|c|c|}
\hline $\begin{array}{l}\text { Example } \\
\text { installation/ } \\
\text { Case study }\end{array}$ & $\begin{array}{c}\text { Employment } \\
\text { effect from } \\
\text { Investment }\end{array}$ & $\begin{array}{c}\text { Employment, } \\
\text { operation/year } \\
\text { incl. fuel }\end{array}$ & $\begin{array}{c}\text { Employment, } \\
\text { operation/13 yrs, } \\
\text { incl. fuel }\end{array}$ & $\begin{array}{c}\text { Income } \\
\text { withdrawal } \\
\text { effects/13 yrs. }\end{array}$ & $\begin{array}{c}\text { Net effects/ } \\
13 \text { yrs. } \\
\text { cumulated }\end{array}$ \\
\hline Job years & $\begin{array}{c}\text { Job years/ } \\
\text { year }\end{array}$ & Job years & Job years & Job years \\
\hline Biomass & 102,5 & 14,0 & 182,3 & $-202,7$ & 82,1 \\
\hline Biogas & 13,8 & 6,7 & 87,5 & $-37,8$ & 63,5 \\
\hline $\begin{array}{l}\text { Small hydro } \\
\text { power (new } \\
\text { installations) }\end{array}$ & 16,1 & 1,4 & 18,7 & $-41,1^{*}$ & $-6,3^{*}$ \\
\hline
\end{tabular}

Source I H S, Carinthia, job years (full time equivalent);

* Note: the effects are calculated by lower market price or higher compensation of energy for the reason of difficult forecast opportunities and lack of storage of the electricity from wind power;

Cited from Energie-Control $\mathrm{GmbH}$, "Bericht über die Ökostrom-Entwicklung und fossile Kraft-Wärme-Kopplung in Österreich“, gemäß § 25 Abs 1 Ökostromgesetz (BGBI I Nr 149/2002)“ zur Vorlage beim Bundesminister für Wirtschaft und Arbeit und beim Elektrizitätsbeirat, Juni 2005 mit Ergänzung der Halbjahresdaten 2005 im August 2005, http://www.e-control.at; 
Table 28: Subsidy per job year (net effect) of investment in facilities using renewable energy, Austria (typical case studies calculated in 2005, representative for major part of granted green electricity installations in the last 2 years)

\begin{tabular}{|l|c|c|c|}
\hline $\begin{array}{l}\text { Example installation/ } \\
\text { Case study }\end{array}$ & $\begin{array}{c}\text { Subsidy cumulated/ } \\
13 \text { yrs. }\end{array}$ & $\begin{array}{c}\text { Net effect cumulated/ } \\
13 \text { yrs. }\end{array}$ & $\begin{array}{c}\text { Subsidy/Job year } \\
\text { (net-effect) }\end{array}$ \\
\hline Biomass & Mio EUR & Job years & EUR \\
\hline Biogas & 13,5 & 82,1 & 164,434 \\
\hline Wind power & 2,5 & 63,5 & 39,370 \\
\hline $\begin{array}{l}\text { Small hydro power } \\
\text { (new installations) }\end{array}$ & 1,7 & $-6,3$ & $\begin{array}{c}\text { no positive net } \\
\text { employment effect }\end{array}$ \\
\hline
\end{tabular}

Source: I H S, Carinthia, job years (full time equivalent), cited from Energie-Control $\mathrm{GmbH}$, "Bericht über die Ökostrom-Entwicklung und fossile Kraft-Wärme-Kopplung in Österreich", gemäß § 25 Abs 1 Ökostromgesetz (BGBI I Nr 149/2002)“ zur Vorlage beim Bundesminister für Wirtschaft und Arbeit und beim Elektrizitätsbeirat, Juni 2005 mit Ergänzung der Halbjahresdaten 2005 im August 2005, http://www.e-control.at.

Table 29: Presumptions concerning the case studies (in Table 27)

\begin{tabular}{|l|c|c|c|c|c|c|c|}
\hline $\begin{array}{l}\text { Example } \\
\text { installation/ } \\
\text { Case study }\end{array}$ & Power & $\begin{array}{c}\text { Green electricity } \\
\text { production/year }\end{array}$ & $\begin{array}{c}\text { Feed in } \\
\text { tariffs }\end{array}$ & $\begin{array}{c}\text { Market price } \\
\text { (presumption } \\
\text { for calculations) }\end{array}$ & $\begin{array}{c}\text { Additional } \\
\mathrm{CO}_{2} \\
\text { value }\end{array}$ & Subsidy/year & $\begin{array}{c}\text { Subsidy/cumul. } \\
13 \text { years }\end{array}$ \\
\hline Biomass & $\mathrm{kW}$ & $\mathrm{GWh}$ & Cent/kWh & Cent/kWh & Cent/kWh & Mio EUR/y. & Mio EUR \\
\hline Biogas & 2.900 & 13 & 12,8 & 4,5 & 0,3 & 1,04 & 13,5 \\
\hline Wind power & 2.000 & 4,4 & 14,5 & 4,5 & 0,3 & 0,19 & 2,5 \\
\hline $\begin{array}{l}\text { Small hydro } \\
\text { power (new } \\
\text { installations) }\end{array}$ & 5.000 & 25 & 4,3 & 4,5 & 0,3 & 0,13 & 1,7 \\
\hline
\end{tabular}

Source: I H S, Carinthia, cited from Energie-Control GmbH, "Bericht über die Ökostrom-Entwicklung und fossile Kraft-Wärme-Kopplung in Österreich“, gemäß § 25 Abs 1 Ökostromgesetz (BGBI I Nr 149/2002)" zur Vorlage beim Bundesminister für Wirtschaft und Arbeit und beim Elektrizitätsbeirat, Juni 2005 mit Ergänzung der Halbjahresdaten 2005 im August 2005, http://www.e-control.at.

Table 30: Employment effects related to green electricity production (Austria, 2004) in person-years (full time equivalents)

\begin{tabular}{|l|c|c|c|c|}
\hline & $\begin{array}{c}\text { Effect from } \\
\text { investment }\end{array}$ & $\begin{array}{c}\text { Operation effect } \\
20 \text { yrs. }\end{array}$ & $\begin{array}{c}\text { Income withdrawal } \\
\text { effect } \\
13 \text { or } 20 \text { yrs. }\end{array}$ & Net effect \\
\hline Wind power & $2.549,6$ & $4.584,3$ & $-7.562,9$ & $-492,0$ \\
\hline Photovoltaics & 303,6 & 57,0 & $-531,1$ & $-170,4$ \\
\hline Small hydro power & 887,1 & $369,9^{*}$ & $-118,4$ & $1.138,6$ \\
\hline Biomass non-liquid & 607,0 & $1.659,9$ & $-1,805,7$ & 461,2 \\
\hline Biogas & 213,5 & $2.080,0$ & $-865,7$ & $1.427,8$ \\
\hline Biomass liquid & 13,1 & 88,4 & $-28,0$ & 73,5 \\
\hline Waste management gas & 61,7 & 23,9 & $-57,1$ & 28,5 \\
\hline Total & $4.635,7$ & $8.863,4$ & $-10.968,9$ & $2,530,2$ \\
\hline $\begin{array}{l}\text { Total without Small hydro } \\
\text { power }\end{array}$ & $3.748,6$ & $8.493,5$ & $-10.850,5$ & $1.391,5$ \\
\hline
\end{tabular}

* By small hydropower a period of operation of $30 \mathrm{yrs}$. Is presumed; Source: I H S Carinthia, cited from Bodenhöfer $\mathrm{H}$., et al., "Bewertung der volkswirtschaftlichen Auswirkungen der Unterstützung von Ökostrom in Österreich", Institut für Höhere Studien Kärnten, Klagenfurt, Juli 2004. 
Table 31: Value added effects of increase in green electricity production, Austria 2004 in mio $€$

\begin{tabular}{|l|c|c|c|c|c|c|c|c|}
\hline & \multicolumn{2}{|c|}{$\begin{array}{c}\text { Effect from } \\
\text { investment }\end{array}$} & \multicolumn{2}{c|}{$\begin{array}{c}\text { Operation effect } \\
20 \text { yrs. }\end{array}$} & \multicolumn{2}{c|}{$\begin{array}{l}\text { Income withdrawal } \\
\text { effect; 13 or 20 yrs. }\end{array}$} & \multicolumn{2}{c|}{ Net effect } \\
\hline & Domestic & Abroad & Domestic & Abroad & Domestic & Abroad & Domestic & Abroad \\
\hline Wind power & 147,1 & 75,7 & 257,7 & 75,2 & $-407,4$ & $-119,2$ & $-2,7$ & 31,8 \\
\hline Photovoltaics & 17,6 & 9,4 & 3,8 & 1,4 & $-28,6$ & $-8,1$ & $-7,2$ & 2,7 \\
\hline Small hydro power & 49,4 & 19,3 & $20,5^{*}$ & $7,2^{*}$ & $-6,4$ & $-1,9$ & 63,5 & 24,7 \\
\hline Biomass non-liquid & 34,2 & 15,0 & 89,8 & 32,7 & $-97,3$ & $-28,4$ & 26,8 & 19,2 \\
\hline Biogas & 11,9 & 4,7 & 45,5 & 14,3 & $-46,6$ & $-13,6$ & 10,8 & 5,4 \\
\hline Biomass liquid & 0,7 & 0,3 & 2,1 & 0,6 & $-1,5$ & $-0,4$ & 1,3 & 0,5 \\
\hline $\begin{array}{l}\text { Waste management gas } \\
\text { (Klär-/Deponiegas) }\end{array}$ & 3,5 & 1,6 & 1,3 & 0,5 & $-3,1$ & $-0,9$ & 1,8 & 1,2 \\
\hline Total & 264,4 & 126,1 & 420,7 & 131,9 & $-590,9$ & $-172,5$ & 94,2 & 85,5 \\
\hline $\begin{array}{l}\text { Total without Small } \\
\text { hydro power }\end{array}$ & 215,0 & 106,8 & 400,2 & 124,7 & $-584,5$ & $-170,7$ & 30,7 & 60,8 \\
\hline
\end{tabular}

*By small hydropower is a period of operation of 30 yrs. Presumed; Source: I H S Carinthia, cited from Bodenhöfer $\mathrm{H}$., et al., "Bewertung der volkswirtschaftlichen Auswirkungen der Unterstützung von Ökostrom in Österreich", Institut für Höhere Studien Kärnten, Klagenfurt, Juli 2004.

Table 32: Presumptions concerning different technologies (in Table 30, Table 31)

\begin{tabular}{|c|c|c|c|c|c|c|c|c|c|c|c|}
\hline & Unit & Wind & PV & $\begin{array}{l}\text { Small hydro } \\
\text { power }\end{array}$ & $\begin{array}{l}\text { Biomass } \\
\text { Forest } \\
\text { chopping } \\
\text { material }\end{array}$ & $\begin{array}{l}\text { Biomass } \\
\text { Forest } \\
\text { chopping } \\
\text { material }\end{array}$ & $\begin{array}{l}\text { Biomass } \\
\text { saw } \\
\text { chopping } \\
\text { material }\end{array}$ & $\begin{array}{l}\text { Biomass } \\
\text { saw } \\
\text { chopping } \\
\text { material }\end{array}$ & Biogas & $\begin{array}{l}\text { Biomass } \\
\text { liquid }\end{array}$ & $\begin{array}{l}\text { Waste } \\
\text { manage- } \\
\text { ment gas }\end{array}$ \\
\hline Power & $\mathrm{kW}$ & 2.000 & 10 & 5.000 & 5.000 & 5.000 & 5.000 & 5.000 & 250 & 500 & 500 \\
\hline Fully powered & h/y. & 2.200 & 1.000 & 5.000 & 4.000 & 7.000 & 4.000 & 7.000 & 7.000 & 5.000 & 6.200 \\
\hline Production & GWh/y. & 4,4 & 0,01 & 25 & 20 & 35 & 20 & 35 & 1,75 & 2,5 & 3,1 \\
\hline Feed in tariff & Cent & 7,8 & 60 & 4,30 & 15 & 15 & 12 & 12 & 14,5 & 10 & 6 \\
\hline Market prise & Cent/kWh & 3 & 3 & 3 & 3 & 3 & 3 & 3 & 3 & 3 & 3 \\
\hline $\mathrm{CO}_{2}$ reduction & $\mathrm{Kg} / \mathrm{kWh}$ & 0,3 & 0,3 & 0,3 & 0,3 & 0,3 & 0,3 & 0,3 & 0,3 & 0,3 & 0,3 \\
\hline Certificate price & Euro/t & 10 & 10 & 10 & 10 & 10 & 10 & 10 & 10 & 10 & 10 \\
\hline $\begin{array}{l}\mathrm{CO}_{2}-\text { credit } \\
\text { (Gutschrift) }\end{array}$ & Cent/kWh & 0,3 & 0,3 & 0,3 & 0,3 & 0,3 & 0,3 & 0,3 & 0,3 & 0,3 & 0,3 \\
\hline Value of electricity & Cent/kWh & 1,8 & 1,8 & 3 & 3 & 3 & 3 & 3 & 3 & 3 & 3 \\
\hline $\begin{array}{l}\text { Value of electricity, } \\
\text { incl. } \mathrm{CO}_{2}-\text { credit }\end{array}$ & Cent/kWh & 2,1 & 2,1 & 3,3 & 3,3 & 3,3 & 3,3 & 3,3 & 3,3 & 3,3 & 3,3 \\
\hline $\begin{array}{l}\text { Specific additional } \\
\text { costs }\end{array}$ & Cent/kWh & 5,7 & 57,90 & 1,00 & 11,70 & 11,70 & 8,70 & 8,70 & 11,20 & 6,70 & 2,70 \\
\hline Sum of subsidy & Mio. Euro/y. & 0,25 & $1,15^{*}$ & 0,25 & 2,34 & 4,09 & 1,74 & 3,04 & 0,196 & 0,167 & 0,084 \\
\hline
\end{tabular}

Figure 26: Share electricity from renewable energy sources (1997 and 2010 target)

Percentage targets for electricity produced from renewable energy sources under Directive 2001/77/EC

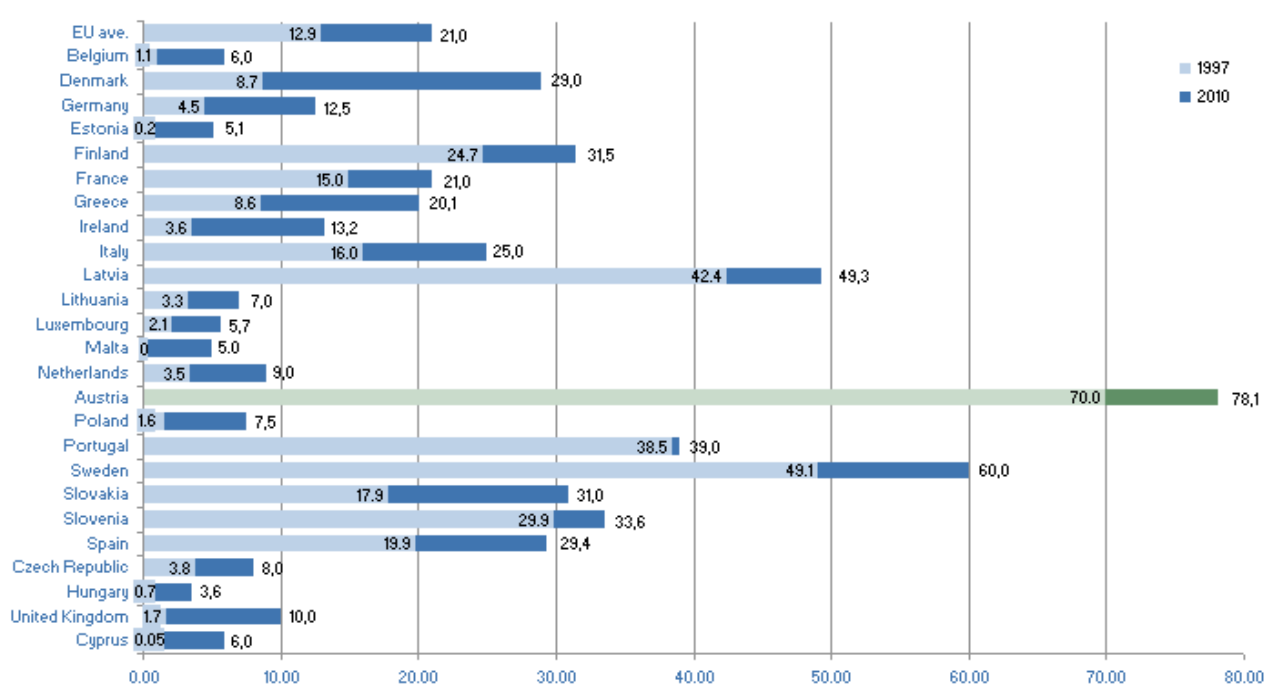

Source: E-control, in: http://www.e-control.at, state Oct. 2006. 
Table 33: Gross domestic electricity production 2005, Austria

\begin{tabular}{|l|c|c|}
\hline Source & $\begin{array}{c}\text { Electr. prod., } \\
\text { TWh }\end{array}$ & $\begin{array}{c}\text { Share in electr. } \\
\text { prod., } \%\end{array}$ \\
\hline Hydropower, incl: & 39,02 & $6 \%$ \\
\hline Small hydro power & 4 & $6 \%$ \\
\hline Other green electricity & 3,78 & \\
\hline Domestic electricity production & 66,36 & $64 \%$ \\
\hline Sum renewable & 42,80 & $76 \%{ }^{\star *}$ \\
\cline { 2 - 3 }
\end{tabular}

Note: *green electricity according to the Green electricity act;

${ }^{* *}$ share from the basis 56,1 TWh (1997) see http://www.e-control.at

Source: Data from Austrian Federal Ministry of Agriculture, Forestry, Environment and Water Management, Dep. V/10, Leader: Dr. M. Schuster, state as of 18.8.2006, contact: Mag. A. Blaser, Oct. 2006; own calculations.

Table 34: Solar power plants, turnover, jobs, exports (2000-2005), Austria

\begin{tabular}{|c|c|c|c|c|c|c|}
\hline & 2000 & 2001 & 2002 & 2003 & 2004 & 2005 \\
\hline $\begin{array}{c}\text { Turnover, in } \\
\text { mio. } €\end{array}$ & 122 & 151 & 131 & 152 & 178 & 232 \\
\hline Jobs & 1.739 & 2.155 & 1.867 & 2.168 & 2.541 & 3.320 \\
\hline
\end{tabular}

Source: G. Faninger, “Der Solarmarkt in Österreich 2005”, März 2006, im Auftrag des BMVIT.

Table 35: Total Eco-industry employment in the EU (1999)

\begin{tabular}{|l|r|r|r|}
\hline Countries & $\begin{array}{c}\text { Total direct } \\
\text { Employment }\end{array}$ & $\begin{array}{c}\text { Total indirect } \\
\text { Employment }\end{array}$ & $\begin{array}{c}\text { Environmental } \\
\text { employment (direct) as \% } \\
\text { of national employment }\end{array}$ \\
\hline Austria & 86.400 & 26.100 & 2,3 \\
\hline Belgium & 49.400 & 13.500 & 1,2 \\
\hline Denmark & 80.600 & 26.300 & 3,0 \\
\hline Finland & 25.200 & 6.300 & 1,1 \\
\hline France & 402.000 & 122.800 & 1,8 \\
\hline Germany & 502.500 & 148.900 & 1,4 \\
\hline Greece & 42.400 & 10.500 & 1,1 \\
\hline Ireland & 11.200 & 2.900 & 0,7 \\
\hline Italy & 168.900 & 46.600 & 0,8 \\
\hline Luxembourg & 3.100 & 800 & 1,6 \\
\hline Netherlands & 109.200 & 35.600 & 1,5 \\
\hline Portugal & 52.400 & 11.900 & 1,1 \\
\hline Spain & 139.600 & 34.200 & 1,0 \\
\hline Sweden & 33.000 & 9.000 & 0,8 \\
\hline UK & 379.700 & 85.800 & 1,4 \\
\hline EU-15 & 2.085 .700 & 581.300 & 1,3 \\
\hline
\end{tabular}

Source: ECOTEC Research and Consulting Ltd., "Analysis of the EU eco-industries, their employment and export potential, A Final Report to DG Environment", Birmingham, 2002. 


\section{$4 \quad$ Employment Policy}

\subsection{Labour Market and Employment Policy}

\section{Summary}

Generally, the situation of the Austrian labour market is favourable in terms of the overall trends regarding unemployment or employment growth. Moreover, the long-term unemployment is still relatively small in an EU-wide comparison.

Employment levels are high in total and for women in all age groups. With regard to older workers, however, a significant employment potential is not exploited, as participation rates remain persistently at unacceptable low levels. Despite considerable reform efforts in recent years, policies have failed to lift effective retirement age in Austria significantly.

With regard to gender specific differences Austria performs well in terms of female participation. Female employment and activity rates are above the EU-averages, the female unemployment rate and the employment rate are beneath. This, of course, does not apply for women in all groups. Generally, older women and women with low educational attainment are less integrated. While the gender employment gap is less discernible in the total population, a high gender pay gap can still be identified especially in the private sector and for older workers.

Special attention should be paid to the development of youth unemployment. Although youth unemployment is still beneath EU-25 and EU-15 averages, it has been increasing dramatically in recent years. Starting at an unemployment ratio of $2.8 \%$ in 2000, the unemployment rate for the age group between 15 and 25 was $6.1 \%$ in the year 2005 . This applies to both men and women.

The Austrian labour market performs rather homogeneously in terms of territorial and regional disparities. There already exists a high degree of territorial cohesion regarding employment and unemployment rates.

In recent years, the Austrian government has undertaken considerable efforts - along the lines of the Employment Guidelines - to improve the functioning of the labour market und to assist persons on the labour market in their successful search for adequate jobs. On top of these programmes in operation, additional measures have been implemented in connection with the NRP. The composition of the NRP measures adequately reflects the identified problem areas on the Austrian labour market.

Based on existing evaluations of comparable labour market initiatives at national and international levels, the potential impact of the NRP can be roughly estimated. Given the 
available figures for additional participants in various types of labour market programmes, additional employment of around 30.000 persons could be generated. This may result in an increase of real GDP of about $1 / 2 \%$. It should be noted, however, that these figures are a very rough first estimate and that they should be regarded as an upper limit of the potential impact of the NRP. 
Figure 27: Effects of NRP on Economic Interactions - Labour Market and Employment Policy

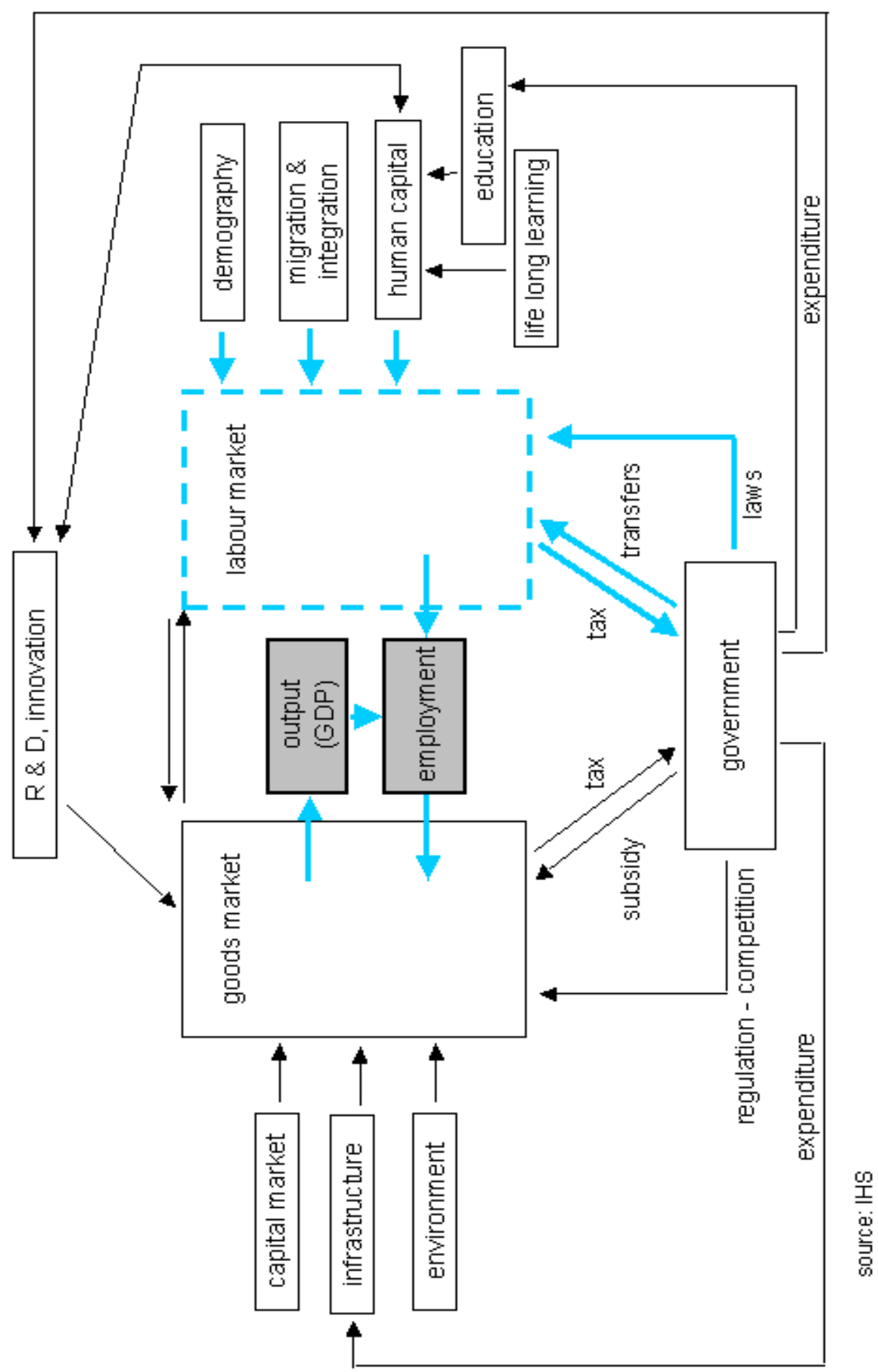




\section{Labour Market and Employment Policy - an overall assessment}

The employment chapter of the Integrated Guidelines of the Lisbon Agenda focuses on three key aspects: (1) full employment, (2) improving quality and productivity at work and (3) strengthening social and territorial cohesion.

Achieving full employment and reducing unemployment and inactivity by increasing demand for and supply of labour is vital to sustain economic growth and reinforce social cohesion. Efforts to raise employment rates go hand in hand with improving the attractiveness of jobs, the quality at work and labour productivity growth, and reducing the share of working poor. Synergies between quality at work, productivity, and employment should therefore be fully exploited. Determined action is needed to strengthen social inclusion, prevent exclusion from the labour market and support integration into employment of people at a disadvantage. It is also necessary to reduce regional disparities in terms of employment, unemployment and labour productivity, especially in regions lagging behind.

The Lisbon Strategy wants to raise employment levels through labour market and structural policies, whereby EU Member States aim at achieving an overall average EU employment rate of $70 \%$ in 2010 . Sub-targets comprise employment levels of at least $60 \%$ for women and $50 \%$ for older workers (55 to 64 ) as well as the reduction of unemployment and inactivity. Member States are encouraged to set national employment targets. In 2005, Austrian employment rates were $68.6 \%$ in total, $62.0 \%$ for women and $31.8 \%$ for older workers. The overall employment rate was slightly beneath EU-target; it was slightly higher for women and distinctively beneath target for older workers (Figure 28).

\section{Figure 28: Employment rate targets and the situation in Austria}

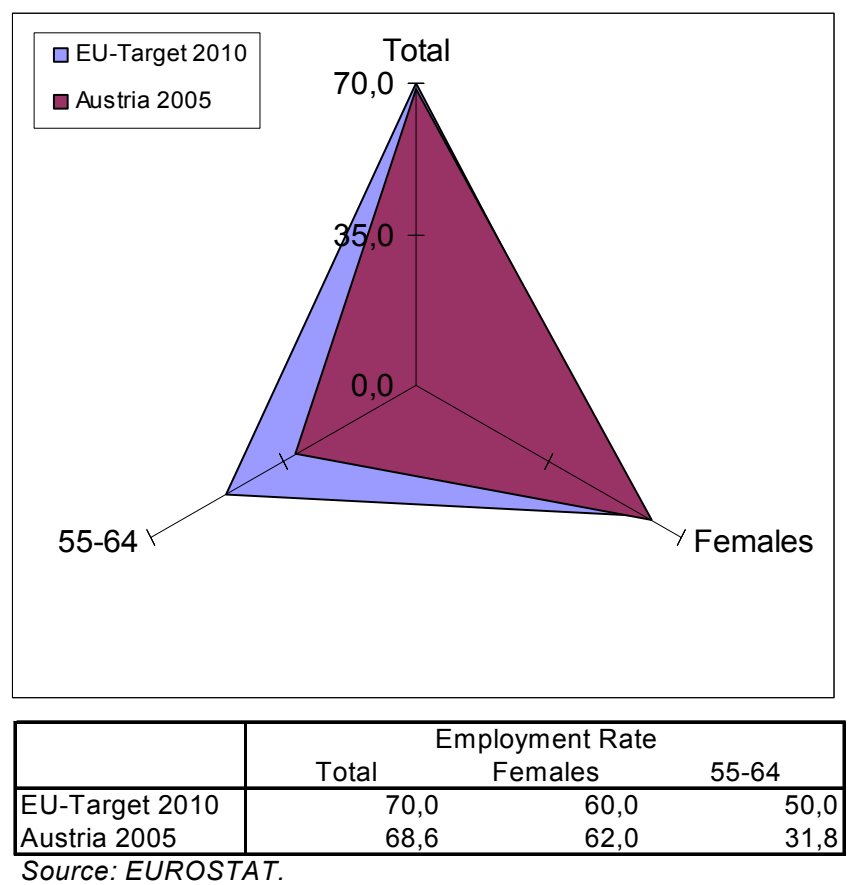


Beside the more quantitative targets of increasing employment rates and contributing to full employment, the Lisbon Strategy also features qualitative and structural aspects. Against this background Member States are requested to raise labour quality and productivity as well as to strengthen social and territorial cohesion.

\section{Potential Impact of the Employment Promotion Act}

Active labour market policies, such as the Employment Promotion Act, are of particular relevance for Lisbon Strategy. The following subsection exclusively focuses on potential employment effects of measures within this Act, followed by a target group analysis to offer a more detailed insight for women, youth, older workers, and disadvantaged persons.

Aggregate effects from ALMP might derive from an increasing matching efficiency. They can be generally described on the basis of a matching model (see European Commission 2006, 121). The matching of unemployed and vacancies takes place in a situation of externalities and imperfect information. The matching process involves information costs. ALMP interventions can reduce information costs by providing information and transparency within the scope of job-search assistance and correct for externalities by influencing the incentive structure between private and public interests (for example through the promotion of labour market training or wage subsidies in the private sector). Hypothetically ALMP increases the efficiency of the matching process and thus decreases structural unemployment (see European Commission 2006, 121). As matching efficiency increases the number of unemployed at a given stock of vacancies decreases, which would correspond to a reduction of structural unemployment.

In September 2005, the Austrian Parliament adopted the Employment Promotion Act. It provides a legal basis for the expansion of active labour market spending by 284.6 million $€$. Compared to expenditure on active labour market policy in 2004 (793 million $€$ without paid benefits during LMP measure participation), these additional funds for 2006 and 2007 correspond to a significant increase of resources.

Implemented by the National Employment Service (AMS), the employment initiative "Unternehmen Arbeitsplatz", which comprehends five focus fields - health and nursing care services, women, younger people, elder and low-skilled men and long-term unemployed plans to additionally reach 61,500 persons in 2006. Compared to the number of participants in 2004 (about 131,000 persons in these special BeFG programmes and measures), the employment initiative allows for a noticeable increase in participants $(+47 \%)$. 
Table 36: Focuses of employment initiative "Unternehmen Arbeitsplatz" - additional funds and scheduled participants

\begin{tabular}{|l|r|r|}
\hline & $\begin{array}{c}\text { additional } \\
\text { participants } \\
\text { scheduled for } \\
2006\end{array}$ & $\begin{array}{c}\text { additional } \\
\text { Funds in euros }\end{array}$ \\
\hline 1. AMS focus on Health and Nursing Care Services & 1,400 & $6,900,000$ \\
2. Focus Women & 5,800 \\
2.1. Employment measures: SÖB, GBP and direct employment subsidies & $18,000,000$ \\
2.2. Qualification & 8,800 \\
2.2.1. Certified trainings courses & 400 \\
2.2.2. Qualification with apprenticeship graduation & $45,655,000$ \\
3. Focus Youth & $13,066,667$ \\
3.1. Project O6: Subsidies for additional apprenticeships & 7,000 \\
3.2. Promotion of secondary school graduation & 1,600 \\
3.3. Jobs4You(th): Qualification and employment measures & 22,000 \\
4. Combined wage modell & 3,000 \\
5. Focus Men & $9,800,000$ \\
5.1. Promotion of low skilled men in middle working age (25-50) & $82,451,119$ \\
5.2. Promotion of elderly (50+) & $14,100,000$ \\
TOTAL & 7,100 \\
\hline Source: AMS. & $23,003,502$ \\
\end{tabular}

\section{Gross-effects of Austrian ALMP}

With regard to the impact of active labour market policy, evaluation studies highlight that effects differ between measurement types and target groups (see for example Grubb et al, 2001, Hofer et al, 2006, Fay, 1996). The most recent study dealing with employment effects of different instruments in Austria was carried out in the context of the evaluation of the European Social Fund (see Lutz et al, 2005). ${ }^{112}$ This study applied different methods in order to estimate the treatment effects of active labour market policy co-financed by the ESF.

Since ESF is seen as a financing component of Austrian labour market policy in general, the study comprehends general evidence regarding instruments and measures that are also relevant within the context of the employment initiative "Unternehmen Arbeitsplatz" i.e. formal training, employment subsidies, project-based employment measures like socio-economic enterprises (SÖB), non-profit oriented companies in the third sector (GBP) and other training programmes like orientation and job search assistance.

In the following section, the impact of the "Unternehmen Arbeitsplatz" employment initiative is estimated on the basis of ESF results. The most relevant criterion is the number of participants changing into employment within nine months after the end of the programme (transition rates into employment); results thus correspond to a gross-impact of ALMP.

Caveat: The underlying method aims at participants changing into employment after finishing a programme. Thus it ignores long-term and causal effects. The transition rates into occupation do not give evidence whether persons stay in occupation (long-term effects) or

\footnotetext{
${ }^{112}$ WIFO-publication downloadable from: http://www.esf.at/downloads/publikationen/EndbewertungProgrammsicht.pdf.
} 
change into employment because of their participation (causal effects). Note again that figures are estimates based on the application of ESF-results.

The main focus of the initiative is on training, which comprises both education and qualification enhancement. Courses offer vocational training (which leads to certified qualification equivalent to an apprenticeship degree) or training for specific skills, like languages or computer abilities (see Hofer H. et al., 2006, 5).

"Unternehmen Arbeitsplatz" helps to promote the full employment target. Within the AMS focus on health and nursing care, participants receive a certified qualification as assistant nurses for resident and other care, elder care professionals, caregivers to disabled or certified nurses. Funds from the employment initiative allow for an increase in persons participating in qualification courses (+1,400 persons). According to the results of the ESF evaluation (see Lutz et al, 2005), 33.8\% of participants in formal training change into an occupation within the first three months after the end of the programme. $11.7 \%$ change into an occupation between the third and the sixth months and $7.9 \%$ between the sixth and the ninth months. Hence $53.4 \%$ of the participants in formal training change into an occupation within the first nine months. Applied to above 1,400 participants, it can be expected that approx. 750 persons will start work within the first nine months after the programme.

Within qualification measures for women, participants either attend certified courses in the entire spectrum of professional work or attend intensive courses, which offer degrees equivalent to apprenticeship degrees (Facharbeiterintensivausbildung). In 2006, an additional 8,800 women took part in certified training courses and 700 in intensive courses. According to the ESF-results, transition rates into employment after such formal training are generally higher for women than for men: $54.9 \%$ of female participants are expected to change into employment within the first nine months. ${ }^{113}$ Accordingly, 5,200 women should change into employment within nine months after the end of their courses.

Regarding women supported by employment subsidies, we apply a transition rate of $72.0 \%$. This corresponds to an average transition rate for participants in socio-economic enterprises (SÖB), job schemes in the non-profit sector (GBP), and direct employment subsidies in the private sector weighted by the respective case structure. Using such transition rate of $72 \%$, we expect that 4,370 of the 5,800 participants in courses will stay in employment, or change into employment, within nine months after the phase-out of the subsidy.

The relatively high transition rate for employment subsidies is explained by the granting of subsidies being linked to the uptake of occupation. Transition rates contain information on

\footnotetext{
${ }^{113} 34.4 \%$ of female participants start an occupation within the first three months, $12.3 \%$ within the third and the sixth months and $8.2 \%$ within the sixth and the ninth months.
} 
how many participants stay in the same job, or change into another job after the end of the subsidy. Above rates do not give evidence on whether participants stay in employment, or whether they become unemployed (or inactive) after the transition is completed. The ESF results indicate that whereas the share of persons changing into employment or staying employed after the phase-out of the subsidies is relatively high, employment periods subsequent to subsidisation periods are instable.

Based on ESF results, only $63 \%$ of women promoted by employment subsidies are still in employment nine months after the end of the programme; $24.8 \%$ are again unemployed and $7.5 \%$ are inactive. Results are worse for female participants in socio-economic enterprises and job schemes in the non-profit sector. Only $38.6 \%$ are still in occupation nine months after the end of the programme whereas $36.1 \%$ are again unemployed and $17.6 \%$ inactive.

The ESF evaluation also contains information on the impact of ESF co-financed programmes for people younger than 25 years which is applicable to the Jobs4You(th) programme. According to the ESF evaluation, $72 \%$ of people under 25 years change into employment within nine months after taking part in a formal qualification programme (see Lutz et al. 2005). Applied to the 19,300 participants additionally scheduled for Jobs4You(th) with "Unternehmen Arbeitsplatz" funds, 13,900 are expected to start an occupation within nine months after the end of their qualification programme.

For employment measures within the Jobs4You(th) programme, a transition rate is estimated based on the average transition rate for the different types of employment measures (GBP, SÖB, direct subsidies) weighted by the case structure. Accordingly, we apply a rate of $75,5 \%$, indicating that of 2,700 participants scheduled for such measures about 2,000 will change into unsubsidised employment within the first nine months.

For low-skilled male workers in middle working age (prime-age males) we apply transition rates of $51.9 \%$ for qualification programmes and $71.7 \%$ for employment subsidisation (direct employment subsidies and project-oriented employment measures). Based on this rate, we expect 4,000 men to change into employment within nine months after the end of their programme. For men older than 50 we apply transition rates of $36.9 \%$ for qualification programmes and $48.1 \%$ for employment subsidisation and expect that 1,710 persons of this age group will change into employment within nine months after their programme. 
Table 37: Estimation of gross impact according to ESF-results ${ }^{114}$

\begin{tabular}{|c|c|c|c|}
\hline & $\begin{array}{c}\text { additional } \\
\text { participants } \\
\text { scheduled for } \\
2006\end{array}$ & $\begin{array}{c}\text { Transition rate } \\
\text { into } \\
\text { employment }^{*}\end{array}$ & $\begin{array}{l}\text { Estimated } \\
\text { gross impact** }\end{array}$ \\
\hline 1. AMS focus on Health and Nursing Care Services & 1,400 & 53.4 & 748 \\
\hline 2. Focus Women & & & \\
\hline $\begin{array}{l}\text { 2.1. Employment measures: SÖB, GBP and direct employment subsidies } \\
\text { 2.2. Qualification }\end{array}$ & 5,800 & 72.0 & 4,174 \\
\hline 2.2.1. Certified trainings courses & 8,800 & 54.9 & 4,831 \\
\hline 2.2.2. Qualification with apprenticeship graduation & 700 & 54.9 & 384 \\
\hline 3. Focus Youth & & & \\
\hline 3.1. Project 06: Subsidies for additional apprenticeships & 7,000 & n.a. & n.a. \\
\hline 3.2. Promotion of secondary school graduation & 1,600 & n.a. & n.a. \\
\hline 3.3. Jobs4You(th): Qualification and employment measures & & & \\
\hline 3.3.1. Qualification & 19,300 & 72.0 & 13,896 \\
\hline 3.3.2. Employment measures: SÖB, GBP and direct employment subsidies & 2,700 & 75.5 & 2,038 \\
\hline 4. Combined wage modell & 3,000 & n.a. & n.a. \\
\hline 5. Focus Men & & & \\
\hline 5.1. Promotion of low skilled men in middle working age $(25-50)^{* *}$ & & & \\
\hline 5.1.1. Qualification & 5,600 & 51.9 & 2,906 \\
\hline 5.1.2. Employment measures: SÖB, GBP and direct employment subsidies & 1,500 & 71.7 & 1,076 \\
\hline 5.2. Promotion of elderly $(50+)^{* *}$ & & & \\
\hline 5.2.1. Qualification & 2,300 & 36.9 & 849 \\
\hline 5.2.2. Employment measures: SÖB, GBP and direct employment subsidies & 1,800 & 48.1 & 866 \\
\hline TOTAL & 61,500 & & 31,767 \\
\hline
\end{tabular}

*Participants changing into employment within 9 months after the end of the program (according to ESF-results).

**Transition rates according to ESF applied to participants scheduled for 2006.

Source: AMS, WIFO

Calculation: IHS.

Based on the ESF-results, the estimated gross impact or overall potential for participants in the employment initiative to change into employment within nine months after the end of their courses is estimated to be 32,000 persons. ${ }^{115}$

It has to be pointed out that above results do not correspond to long-term effects of labour market programmes since the underlying method does not account for persons becoming again unemployed or inactive once (after) they moved into employment. According to ESFevaluations (see Lutz et al. 2005), only $33 \%$ of participants are still in employment ${ }^{116}$ nine months after the end of the programme. Applied to 61,000 participants of above measures additionally scheduled for 2006 , only about 10,500 will still be in unsubsidised employment at this time.

\section{Causal effects of Austrian ALMP}

The results shown above correspond to a gross-effect. This relies on people changing into employment (or staying in employment respectively) after the programme participation has ended. The underlying method oversees that participants might have changed into

\footnotetext{
${ }^{114}$ Based on the ESF-evaluation from WIFO (see Lutz et al. 2005).

115 This does not include the "Projekt '06", the promotion of secondary school graduation within the focus on youth and the combined wage model respectively. However, according to AMS data the take-up of subsidies in conjunction with the combined wage model is marginal.

${ }^{116}$ In terms of employment (including self-employed) above the marginal earnings threshold.
} 
employment even without participation in a certain programme. Thus the results abstract from so-called deadweight-losses and do not correspond to causal effects.

The evaluation of ALMPs' causal effects is however confronted by an evaluation problem. In order to calculate causal effects of programme participation one would have to compare outcomes of participation to the outcome of a counterfactual, which in this case is nonparticipation. Therefore the evaluator would have to know what the outcome had been for a programme participant if this person had not participated in a programme. Essentially the evaluation problem derives from the fact that the same person cannot be in two different labour market states at the same time. In order to solve this problem micro-economic evaluations mostly apply quasi-experimental evaluation designs. These assess the outcomes for a (often randomized) group of participants against a comparable control group of non-participants.

Regarding training programmes, which are of the highest importance within the context of the employment initiative, a number of evaluations point out the relevance of target groups and programme types. The general conclusion from evaluations is that effects of training programmes are marginally positive. Positive results are reported for some target groups (especially women). According to Martin and Grubb (Grubb et al 2001, 25) the most consistently positive effects are recorded for prime-age females whereas the results seem to be less optimistic for prime-age males and youth. In their study reviews Martin and Grubb identify four aspects in the design of training programmes, which are crucial in order to raise the effectiveness of training programmes: a) the need for tight targeting on participants and target groups, b) the need to keep the programmes small in scale, c) the need for the programme to result in a recognized qualification or certificate and d) the need to have a practical on-the-job component in the programme.

According to Kluve $(2006,10)$ evaluations indicate that training programmes increase the employment probability in particular for participants with better labour market prospects and for women. Based on a meta-analysis of evaluation studies Kluve points out that training programmes have a small positive effect on employment.

It has to be pointed out that negative or only small effects of training programmes might be biased by a negative locking-effect due to reduced effort on job-search of participants in training. According to the OECD Employment Outlook for 2005 (OECD 2005, 183) the participation-related employment gap between participants in training and non-participants declines over time. In order to assess the effectiveness of training programmes long-term effects have to be examined. The long-term effects of training programmes might be better. According to the OECD 2005 Employment Outlook (OECD 2005, 183) the impacts followed over a sufficiently long time period after the training can in some cases become quite strongly positive. 
With regard to job-creation programmes international evaluations came to rather disappointing results. According to the OECD, "most evaluations of public-sector job creation programmes find a small or even negative impact at all time" (OECD 2005, 183). The negative effect might be again caused by a so-called locking-effect. Participants in jobcreation programmes have less time for job-search than jobseekers that do not participate. According to Martin and Grubb evaluations of job-creation programmes mostly come to the result that these measures have only little success in bringing unemployed into regular employment (see Grubb and Martin 2001, 32). According to Kluve $(2006,10)$ the evidence across countries suggests that treatment effects of public sector job-creation on individual employment probabilities are often insignificant, and frequently negative. However some studies identify positive effects for certain social-demographic groups.

Regarding employment subsidies Martin and Grubb refer to evaluation results indicating that these programmes have a larger impact than public training programmes or direct jobcreation programmes (Grubb and Martin 2001, 31). According to Robert Fay (1996, 20) wage subsidies "appear to increase employment slightly" albeit at substantial deadweight and substitution effects. Thus most programmes yield only small net-employment gains. Martin and Grubb refer to evaluations of employment subsidies in Belgium, Ireland or Netherlands for instance suggesting combined deadweight and substitution effects of around 90 per cent.

Regarding the disappointing employment effects deriving from employment subsidies and job-creation programmes it has to be mentioned, that the accordant measures usually differ from other types of ALMP. The programmes are mainly targeted to certain disadvantaged groups such as long-term-unemployed.

Another focus of the employment initiative is on youth. The measures have to be differentiated into the promotion of apprenticeships and within the scope of the Jobs4You(th) ALMP for people younger than 25. The latter includes primarily training and qualification courses, and to a lesser extent (see above) wage subsidies and job-creation programmes. Regarding programmes for the disadvantaged youths international evaluations come to rather disappointing results. According to Martin and Grubb $(2002,28)$ "almost all evaluations show that special measures are not effective for disadvantaged youths." This applies to training programmes as well as to wage subsidies and direct public sector job creation. At least Martin and Grubb refer to some studies suggesting positive outcomes for specific programmes. Denny et al (2000) point out that market-oriented programmes (in particular wage-subsidies in the private sector) yielded positive results for youth in Ireland. Van Reenan (2001) states that a UK programme (New Deal for Young People) led to a significant increase in outflows to employment among young males. The New Deal for Young People started in 1998. The programme comprehended wage subsidies, education and training, government provided employment and voluntary work and was targeted to young people between 18 and 24. Most of this effect derived from wage-subsidies and enhanced 
job search. AM (2000) provides evidence that recent youth measures might have contributed to a fall in Danish youth unemployment in the second half of the 1990s.

Regard youth programmes it has to be pointed out that quite positive results are reported for early and sustained interventions. The Austrian NRP comprehends activities in these fields within the NRP.

\section{Net-effects based on macroeconomic studies}

Net-effects of labour market policies on aggregated employment rates differ in macroeconomic studies. For example, G. Mourre (2006). examined the relationship between ALMP and employment growth in order to explain European employment growth from 1997 to 2001. According to his results, the sectoral allocation of growth and employment as well as structural changes (part-time jobs or lower tax wages) have particularly contributed to the increase of aggregate employment during this period. However, no significant correlation between ALMP expenditures and aggregate employment growth was found. ${ }^{117}$

Based on group-specific regressions between expenditure on ALMP and employment rates in OECD countries, Bassanini and Duval (OECD 2006, 49) found a positive relationship between training expenditure and employment. They analysed the impact of increasing training expenditure (measured per unemployed and as percentage of GDP per capita; increase in percentage points) on employment rates of prime-age males, prime-age females, older workers and youth. In their regression, a 10 percentage point increase of training expenditure was associated with raising employment rates of 1.6 percentage points for prime-age males, 0.5 percentage points for prime-age females, ${ }^{118} 3.4$ percentage points for older workers and 2.6 percentage points for younger people.

According to the BMWA, expenditure for active and activating labour market policy (without expenditure in conjunction with the old-age part-time scheme) amounted to 976.5 million $€$ in 2004. Applying 2004 Eurostat data for the number of unemployed, GDP at current prices and population, an increase of ALMP expenditure by 284.6 million $€$ is associated with an increase of ALMP expenditure ${ }^{119}$ by 3.47 percentage points.

Assuming that this increase applies to all groups in the same way, ${ }^{120}$ this means that the increase of ALMP expenditure associated with the employment initiative (which is primarily

\footnotetext{
${ }^{117}$ Subsidies to regular employment in the private sector are positively correlated to employment growth, although not statistically significant.

${ }^{118}$ The results for prime-age women are not significant.

${ }^{119}$ Measured as ALMP-expenditure per unemployed as percentage of GDP per capita.

${ }^{120}$ The employment initiative is primarily focused on women and youth. Thus the increase of ALMP spending does not apply to all groups in the same way.
} 
focusing on training and qualification) increases the employment rates for prime-age males by 0.6 percentage points, for prime-age females by 0.2 percentage points, for elderly by 0.9 percentage points and for younger people by 1.2 percentage points.

Applied to demographic data for 2004, the increase of expenditure associated with additional funds from the employment initiative would ceteris-paribus increase the number of active persons in employment by 33,700 overall.

Above calculation is based on the assumption that the increase of resources applies to all groups in the same way although the current Austrian employment initiative primarily focuses on women and youth. In addition, and contrary to other micro-economic studies (which assume positive treatment-effects especially for women), Bassanini and Duval find that the effects for women are the weakest and not significant. Therefore, above calculation overestimates employment effects since results are biased by relatively high coefficients for prime-age males and older workers (who benefit less from current additional funds).

Table 38: Aggregate effect on employment rates (Bassanini \& Duval 2006)

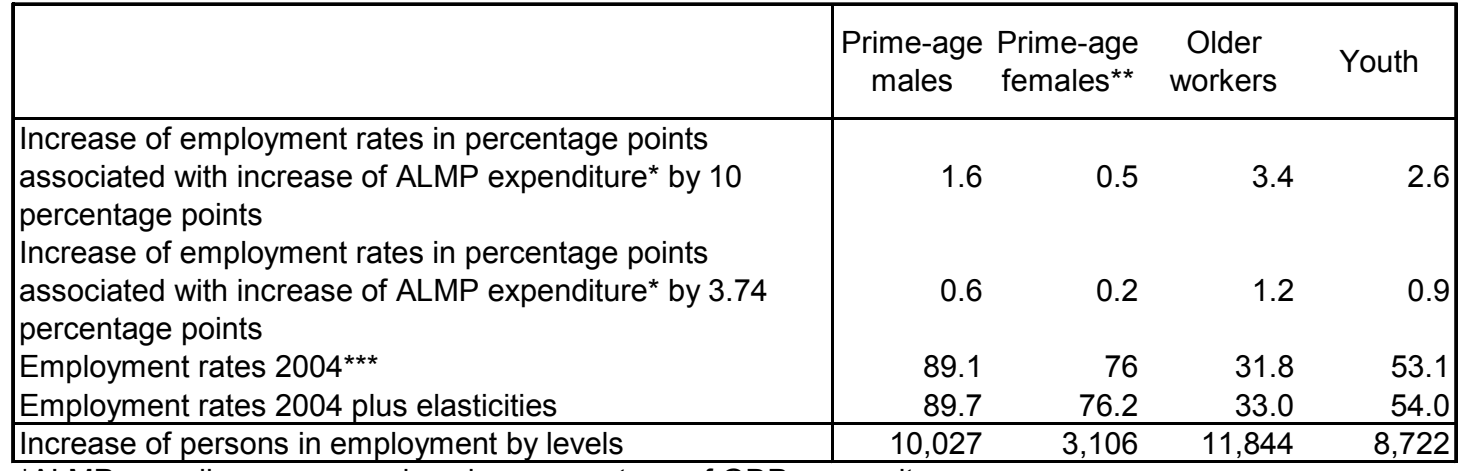

${ }^{*}$ ALMP spending per unemployed as percentage of GDP per capita

${ }^{*}$ Results for prime-age females are not significant

${ }^{* * *}$ Employed active persons as a percentage of same age total population. based on: Bassanini, Duval 2006.

\section{Labour Market and Employment Policies - analysis according to target groups and territorial cohesion}

\section{Women}

Regarding the Lisbon goal to increase the employment of women, Austria has already exceeded the EU-wide target of $60 \%$. Yet, gender gaps concerning employment rates (especially in fulltime equivalents) and unemployment rates are still high and the gender pay gap hardly decreased (Figure 29). 
Due to the lack of successful policy measures to directly approach the gender pay gap, measures address aspects that indirectly influence pay gaps, like qualification (degree, discipline), segregation and reconciliation between gainful employment and family work. Parenthood and the reconciliation of paid and unpaid work still seem to be the main barrier of female (fulltime) employment and successful careers. The employment rate between women with and without children differs by $14.4 \%$, which is slightly above EU15 average (Figure 30). ${ }^{121}$ Career breaks during child care allowance periods are still the norm for Austrian mothers but cause individual problems because of a high risk of unemployment after the leave and productivity losses due to unused human capital.

\section{Assessment of Measures of the Austrian NRP}

Active labour market policy ("Unternehmen Arbeitsplatz"): Within this initiative, which is financially the most important, three measures concentrate on female employment: (1) Special training programmes aims at improving the skills of unemployed women and to support female returners. Another programme was launched to reduce labour market segregation and to integrate more women in crafts, engineering and new technologies; although the initiative comprises only a small number of participants, it is expected to have a high impact on the careers of participating women. Furthermore, the programme is a clear signal of the employment service in the field of labour market segregation and gender imbalances. (2) Another special focus is on the situation of female returnees. In every labour market service office a specially trained women is appointed as contact person for female returnees for whom 5,800 additional qualification options are planned. (3) Focus on care: An additional 1,400 persons will be trained in the field of care due to increasing demand for qualified staff.

Childcare subventions: To facilitate participation in measures of active labour market policy, financial contributions to the costs of childcare are granted to unemployed parents of young children. For 2006 to 2008 , up to yearly 6,000 subventions are planned. In the past, this measure has shown effect on labour supply as well as on labour demand. According to Lutz et al, (2005), an additional demand of about 500 jobs and an additional labour supply of about 1,500 persons can be expected.

Childcare allowance ("Kinderbetreuungsgeld"): The number of people in employment during parental leave episodes significantly increased since 2002. In 2004, approximately $50 \%$ of all leave takers used the possibility to be employed during leave period, at least at a certain point in time. The reason for the increase of people employed above the marginal earnings threshold is a revision of exemption limits: since 2002, parental leave claimants may earn an additional $€ 14,600$ per year.

\footnotetext{
${ }^{121}$ In reality the difference is even higher, because women on parental leave are included in the employment rate.
} 
Table 39: Individuals with paid work during parental leave episodes

\begin{tabular}{|l|c|c|c|c|c|}
\hline & 2000 & 2001 & 2002 & 2003 & 2004 \\
\hline Marginally employed & 6,752 & 7,711 & 535 & 5,320 & 5,701 \\
Employed above GG* & 7,688 & 7,897 & 4,241 & 23,565 & 30,503 \\
Total no of individuals & 57,873 & 58,453 & 8,017 & 51,369 & 62,187 \\
\hline Share of marginally employed & $11.7 \%$ & $13.2 \%$ & $6.7 \%$ & $10.4 \%$ & $9.2 \%$ \\
Share of employed above GG* & $13.3 \%$ & $13.5 \%$ & $52.9 \%$ & $45.9 \%$ & $49.1 \%$ \\
\hline
\end{tabular}

* $\mathrm{GG}=$ marginal earings threshold ("Geringfügigkeitsgrenze"); people in employment and self-employment Source: BMWA 2006: 23.

A major problem concerning parental leave is the low take up of men. Although male participation rose since the early 1990s (male share in leave about $1 \%$ ), only $3.5 \%$ of all leave takers today are men (April 2006). The low interest of men in a take up is partly justified by the restrictions of the exemption limits of $€ 14,600$ per year (cf. ÖIF 2006).

Lutz (2003) pointed out another problem, which is the extension of career interruptions under the current leave regulation as compared to the former system. Since leave periods are usually exhausted (84\%, BMWA 2006: 24), the overall effect on labour supply is negative. This is only partly compensated by the possibility of paid work during parental leave.

Mentoring programme: In 2004, the Federal Ministry for Health and Women's Affairs launched a mentoring project with the aim to establish an Austrian mentoring-network to promote women in business. The project bundled existing mentoring initiatives in companies, on regional-level or within the public sector and offers a platform for single initiatives to interlink. The number of registered initiatives increased from 35 (2004) to 48 (2005), as did the number of mentees and mentors (2004: 1,050 persons, 2005: 1,650 persons). A central event of the programme is an annual conference ("Mentora") where best practices are awarded. Despite growing participation and increasing public awareness, no direct employment effects can be expected. Furthermore the programme creates political and public consciousness of the so-called "glass-ceiling-phenomenon" and is expected to raise the quality of work of participants (mentees).

\section{Effects on Growth and Employment}

Measures to promote equality of women and men mainly tackle the employment and unemployment gap. Programmes promoting female qualification have been extended and should increase employment. This is enforced by the fact that women in general profit better than men from active employment policy (Lutz et al. 2005; Weber, Hofer 2003; Martin, Grubb 2001). Measures that diminish labour market segregation through promotion of qualifications in technical and handicraft fields may also reduce the gender pay gap. A reduction of the pay gap could also result from the Mentoring Programme, which encourages female careers. 
Childcare subsidies (Kinderbetreuungsbeihilfen) are a financial incentive to earlier re-enter the labour market but can also increase the labour demand through the need for more childcare facilities. The reformed childcare allowance (Kinderbetreuungsgeld) should also increase employment of mothers with little children.

To sum up, measures promoting the equality of men and women aim at female qualification and labour supply. Effects of measures for women within the "Unternehmen Arbeitsplatz" can be estimated at about 10,000 job entries within 9 months after the end of the programme (according to the results of the ESF-evaluation). Employment effects of active labour market policy programmes for women are, in general, higher than those for men. Net effects on female employment are positive but moderate. Assuming that one third of female returners participate in socio-economic enterprises while the others mainly participate in formal training comparable to the ESF-measures, a net female employment effect of 470 jobs results. Additional measures to reconcile work and family could positively influence female labour supply: plus 1,500 women, and about 500 jobs in childcare. This outcome is mainly influenced by childcare subsidies, while childcare allowances and mentoring programmes hardly show quantitative effects.

\section{Youth}

Youth unemployment in Austria is still clearly beneath EU-average. In 2005, the youth unemployment ratio $^{122}$ was $6.1 \%$ as compared to $8.4 \%$ (EU25) and $8.0 \%$ (EU15). However, the youth unemployment ratio for both men and women recently increased against the overall EU-trend. The situation is similar with regard to youth unemployment rates. In 2005, the youth unemployment rate was still beneath comparative EU15 and EU25 values. However, compared to the EU-trends, the increase since 2000 was larger in Austria.

Table 40: Youth unemployment ratio

\begin{tabular}{|l|rrrrrr|}
\hline TOTAL & 2000 & 2001 & 2002 & 2003 & 2004 & 2005 \\
\hline EU 25 & 8.4 & 8.0 & 8.2 & 8.4 & 8.3 & 8.4 \\
EU 15 & 7.7 & 6.9 & 7.2 & 7.6 & 7.6 & 8.0 \\
Austria & 2.8 & 3.1 & 3.4 & 3.9 & 5.6 & 6.1 \\
\hline MEN & & & & & & \\
\hline EU 25 & 8.5 & 8.4 & 8.7 & 9.0 & 8.8 & 9.0 \\
EU 15 & 7.7 & 7.1 & 7.6 & 8.1 & 8.0 & 8.5 \\
Austria & 3.0 & 3.4 & 3.9 & 4.5 & 5.7 & 6.8 \\
\hline WOMEN & & & & & & \\
\hline EU 25 & 8.3 & 7.7 & 7.7 & 7.7 & 7.8 & 7.9 \\
EU 15 & 7.8 & 6.8 & 6.8 & 7.0 & 7.3 & 7.6 \\
Austria & 2.7 & 2.8 & 2.9 & 3.2 & 5.4 & 5.4 \\
\hline
\end{tabular}

\footnotetext{
${ }^{122}$ Total unemployed young people (15-24) as a share of population in the same age bracket.
} 
Table 41: Youth unemployment rate

\begin{tabular}{|l|rrrrrr|}
\hline TOTAL & 2000 & 2001 & 2002 & 2003 & 2004 & 2005 \\
\hline EU 25 & 17.4 & 17.7 & 18.3 & 18.8 & 18.9 & 18.7 \\
EU 15 & 15.3 & 15.2 & 15.7 & 16.5 & 16.7 & 16.9 \\
Austria & 5.3 & 5.8 & 6.7 & 8.1 & 9.6 & 10.3 \\
\hline MEN & & & & & & \\
\hline EU 25 & 16.0 & 16.5 & 17.5 & 18.4 & 18.4 & 18.3 \\
EU 15 & 13.8 & 13.7 & 14.8 & 16.0 & 16.2 & 16.5 \\
Austria & 4.7 & 5.2 & 6.4 & 7.3 & 9.4 & 10.4 \\
\hline WOMEN & & & & & & \\
\hline EU 25 & 18.9 & 19.2 & 19.2 & 19.2 & 19.4 & 19.1 \\
EU 15 & 17.1 & 16.9 & 16.8 & 17.0 & 17.3 & 17.3 \\
Austria & 6.0 & 6.5 & 7.1 & 8.9 & 9.8 & 10.3 \\
\hline Source: EUROSTAT. & & & & &
\end{tabular}

Apprenticeship market: The average number of people seeking apprenticeship increased from 5,478 in 2003 to 6,156 in 2005 . Over the same period, the comparative level of open apprenticeship positions reported to the AMS increased more slowly from 2,632 in 2003 to 2,900 in 2005.

Table 42: Apprenticeship labour market

\begin{tabular}{|l|rrr|}
\hline Average levels & 2003 & 2004 & 2005 \\
\hline Apprenticeship seekers & 5,478 & 5,375 & 6,156 \\
Men & & 2,811 & 3,255 \\
Women & & 2,564 & 2,901 \\
Open apprenticeships & 2,632 & 2,356 & 2,900 \\
\hline
\end{tabular}

Source: AMS.

Against the background of the Lisbon Strategy, special attention should be paid to the development of youth unemployment in general. Although youth unemployment in Austria is still beneath EU25 and EU15 average, it increased dramatically in recent years. The apprenticeship system is an important pathway to the labour market and should therefore be watched closely and modified to ensure labour-market oriented qualifications.

\section{Assessment of Measures of the Austrian NRP}

The Jobs4You(th) programme comprises qualification measures and (to a lesser extent) employment subsidies for people under 25 years. With the target to ensure certified and labour-market oriented qualifications, Jobs4You(th) concentrates on long-term unemployed youth between 19 and 24 years. Embedded in the employment initiative "Unternehmen Arbeitsplatz", the programme is expected to reach an additional 22,000 young people. Recent impact analyses on measures reveal that $65 \%$ of participants change into unsubsidised occupation within 6 months after the end of the programme. Applied to the number of participants scheduled for 2006, approx. 14,300 people younger than 25 years are expected to change into employment within the accordant time period. 
An evaluation dealing with impacts of measures carried out within the scope of the $\mathrm{ESF}^{123}$ further differentiates between qualification programmes and employment subsidies. Applied to qualification measures within the Jobs4You(th) initiative, $72 \%$ of participants change into an occupation within 9 months after the end of the programme. Applied to 19,300 participants, an expected 13,900 youth should start an occupation within this time. For employment subsidies, the relevant transition rate was estimated based on average transition rates for different employment subsidies (weighted by case frequencies). Accordingly, we apply a transition rate of $75.5 \%$ for changing into an occupation within 9 months after the phase-out of employment subsidies. With 2,700 recipients, a 2,040 youth are expected change into an occupation within the first 9 months.

To sum up, the Jobs4You(th) initiative is expected to allow 16,300 youth to change into an occupation within 9 months after the end of their programme.

An examination of a comparable programme for youth ("Sonderprogramm für Jugendliche") also shows varying impacts for different measurement types. According to this examination (see BMWA 2004, 19), employment subsidies have the largest employment impact. About $80 \%$ of participants changed into occupation within the first 4 months after the end of the phase-out of the subsidy. The data indicates that, in many cases, a subsidised occupation transformed into a non-subsidised job. With regard to project-based employment subsidies, transition rates were $68 \%$ for job-schemes in the third sector and $63 \%$ for socio-economic enterprises. With regard to participants in qualification courses, $61 \%$ changed into an occupation within the mentioned time period. Nevertheless, further occupational sequences of participants show a high degree of instability: one third of participants became again unemployed or inactive (within 6 months after the end of the programme) after changing into occupation.

Placement and Job-coaching initiative for younger people: Within the scope of the integration-initiative "Chances for the Youth" ("Der Jugend eine Chance"), job search assistance is offered to long-term unemployed people under 25 (unemployment durations over 6 months). The programme is co-financed by the AMS and the Federal Economic Chamber (WKÖ). Over a maximum period of 9 months, a personal coach supports the job search activities of juveniles. The programme comprehends a qualification and orientation module geared to the improvement of social skills. According to AMS information, until September 20052,018 people participated in the programme. The target is to bring 2,000 participants into employment until July 2007.643 of the participants had been already placed into an unsubsidised occupation until September 2006. 104 participants were attending practical training in enterprises. Thus for the first group of participants the placement rate is $72 \%$.

\footnotetext{
${ }^{123}$ See Section "Potential impact of the Employment Promotion Act"
} 
Supra-enterprise-oriented apprenticeship in training centres: The concept of supra-enterprise apprenticeships (überbetriebliche Lehrausbildung) focuses on youths with learning disabilities. Educationally disadvantaged youths without apprenticeship training positions have the possibility to attend traineeships in special training centres (überbetriebliche Ausbildungszentren, ÜAZ). According to information of the government's appointee concerned, existing ÜAZ provide training positions for about 1,000 apprenticeship trainees. For the current programme in $2006 / 07$ it is planned to increase ÜAZ capacities to around 2,000 traineeship positions.

It is the aim of the Youth Training Provision Act (JASG, Jugendausbildungsgesetz) to provide additional apprenticeship training positions for youth who are unable to find suitable training positions within firms. The core of the initiative is represented by training courses lasting up to twelve months, which shall develop appropriate skills of the trainees. Within this comprehensive initiative the ÜAZ has been introduced in 2004/05.

Although no further information exists on the impact of ÜAZ, apprenticeship training courses within the Youth Training Provision Act were evaluated. According to the BMWA, ${ }^{124} 55 \%$ of participants in JASG 4 training courses started a regular apprenticeship within the first month after the end of the programme. Transition rates extend to $67 \%$ within a time period of 6 months after the end of the programme. About $14 \%$ of participants start a subsidised apprenticeship within 6 months. Another evaluation of respective training courses carried out by L\&R Social Research also assumes positive short-term integration impact. Thus $60 \%$ of the persons that participated in trainings courses within the scope of JASG changed into an apprenticeship training position within the first six months. ${ }^{125}$

The positive short-term effect in the apprenticeship system is thwarted by less favourable long-term effects. According to the BMWA examination, the integration after participation in trainings courses into the apprenticeship system is insecure. ${ }^{126}$ Within the first 6 months after the end of the programme about $12 \%$ of the participants become again unemployed. Over an examination period of 12 months about $20 \%$ of JASG 4 participants have started an apprenticeship but became unemployed afterwards.

Blum-Bonus (Projekt '06): With the Blum Bonus, the AMS subsidises employers providing additional apprenticeships. The bonus amounts to $400 €$ per month and apprentice in the first year, $200 €$ in the second and $100 €$ in the third year. The initiative started in September 2005. Until end of April 2006 more than 10,500 persons participated in the programme. The recent development of apprenticeship training positions indicates a positive impact of promotion programmes. The gap between apprenticeship seekers and open positions was

\footnotetext{
${ }^{124}$ BMWA (2004). Arbeitsmarktmonitoring 2004.

${ }^{125}$ Note that the results refer to training courses conducted in the period 1998-2000.

${ }^{126}$ BMWA (2004). Arbeitsmarktmonitoring 2004.
} 
reduced in 2006. Compared to 2005 the number of apprenticeship trainees increased by 7,830, from 111,641 in August 2005 to $119,471$.

\section{Elderly}

Within the context of the Lisbon Strategy, EU Member States are requested to contribute to an employment rate of $50 \%$ for older workers (55 to 64). In 2005, the Austrian employment rate was $31.8 \%$ for older workers, thus ranking markedly below EU average. Corresponding values were $42.5 \%$ for EU25 and $44.1 \%$ for EU15. Traditionally, Austria ranks among the countries with the lowest exit ages from labour force, for both female and male retirement.

\section{Assessment of Measures of the Austrian NRP}

Special programme for elderly (within Employment Promotion Act): This programme comprises active labour market measures and single projects to promote appropriate working conditions for elderly. At present, labour inspectorates establish programmes on age-compliant work and aspects of age-compliant work will be incorporated into labour inspection. The special programme for elderly is budgeted at 4.5 million $€$. The excursus subsequent to the target oriented assessments discusses the potential impact of active labour market programmes within the Employment Promotion Act.

Monetary incentives for the extension of working lives: In recent years, the Austrian Government introduced a number of policies influencing incentive systems regarding the occupation of elderly. They comprise incentives directed at employers as well as older workers: reduction of non-wage labour costs for elderly, Bonus-Malus System providing incentives towards the engagement of elderly and disincentives for dismissal. Such incentives lessen the burden of seniority wages that result in relatively high wage increases at higher ages and thereby causes competitive disadvantages. With regard to net-effects, selective and target-group oriented interventions into labour-costs may cause substitution and displacement effects.

Incentives for extended working lives also come from a fixation of the calculation basis of unemployment benefits (which reduce poverty traps associated with low wages or continued unemployment benefits) if elderly meet eligibility requirements regarding a corridor pension.

Since 2000, the old-age part-time scheme provides compensatory wage payments financed by unemployment insurance (ALV) for older workers who decrease working time. According to OECD sources, the scheme "has opened a highly utilised and fiscally expensive channel into early retirement outside the statutory old age pension system." (OECD 2003, 5) Since 2004, blocking (working full-time during the first years covered by the scheme and ceasing work entirely in the remainder of this period) is only possible if another part-time employee is recruited. Otherwise, financial support is halved (without a new recruitment). 
Although the old-age part-time scheme was intended to provide a reduction of working time without completely leaving the labour market, working time is often "blocked" thus providing incentives to step out labour-force early.

With the Labour Market Reform Act (Arbeitsmarktreformgesetz), the government introduced strengthened job acceptability criteria combined with an adoption of the AMS sanction system. Personalised action plans are to be drafted by the AMS.

According to OECD Employment Outlook 2006, successful activation strategies are amongst others dependent on "judicious mix of incentives. This includes effective re-employment services to help the unemployed find a new job, as well as adequate monitoring of the jobsearch efforts of the unemployed to ensure that they are actively looking for work, backed up by the threat of graduated benefit sanctions" (OECD 2006, 12). The OECD points out, that "careful integration of active and passive measures, combined with close monitoring of job search, can be effective in dampening disincentives effects brought about by generous unemployment benefits." (see OECD 2006; 217).

Yet, unemployment benefits allow jobseekers more time to find better matches, thereby enhancing job stability and productivity (see OECD 2006, 56). Pressure on unemployed may reduce matching quality. Thus, "job search monitoring and sanctions are most effective when they are incorporated into a broader "activation" strategy (OECD 2006, 61). According to the OECD labour supply disincentives from generous unemployment benefits can be off-set, at least to a significant degree, by benefit administration practices that use financial sanctions (i.e. benefit cuts) to enforce an obligation to actively search for work and to accept reasonable job offers (OECD 2006, 59).

The Pension Harmonisation Act (Pensionsharmonisierungsgesetz) created uniform pension law for the entire active population. It involves transparent and performance-based pension accounts for workers aged less than 50 . Early retirement schemes will be gradually abolished and a changed calculation method for pension levels has been introduced. It can be argued that the Pension Harmonisation Act provides mobility between different pension schemes. Thus the Pension Harmonisation Act can be seen as a contribution to a modernisation of social protection systems.

\section{Territorial cohesion}

Regional disparities in employment and unemployment are not very large in Austria. The coefficient of variation of total employment was 3.5 on NUTS II level. Comparative values for EU-25 and EU-15 were 12.2 and 11.1, respectively. With the exception of female employment, heterogeneity increased in 2004. 
Table 43: Regional disparities of employment - Coefficients of variation ${ }^{127}$

EMPLOYMENT

\begin{tabular}{|l|rrrrrr|}
\hline TOTAL & 1999 & 2000 & 2001 & 2002 & 2003 & 2004 \\
\hline EU-25 & 13.30 & 13.40 & 13.50 & 13.30 & 12.90 & 12.20 \\
EU-15 & 13.90 & 13.40 & 13.10 & 12.50 & 11.90 & 11.10 \\
Austria & 2.30 & 2.50 & 2.60 & 2.50 & 2.90 & 3.50 \\
\hline MEN & 1999 & 2000 & 2001 & 2002 & 2003 & 2004 \\
\hline EU-25 & 9.3 & 9.9 & 10.4 & 10.5 & 10.4 & 10.2 \\
EU-15 & 8.8 & 8.6 & 8.6 & 8.3 & 8.1 & 8.1 \\
Austria & 2.2 & 2.2 & 2.5 & 3.7 & 3.6 & 3.9 \\
\hline WOMEN & 1999 & 2000 & 2001 & 2002 & 2003 & 2004 \\
\hline EU-25 & 21 & 20.5 & 20.1 & 19.6 & 18.8 & 17.3 \\
EU-15 & 22.7 & 21.8 & 21 & 20.1 & 19.1 & 17.3 \\
Austria & 4.2 & 4.4 & 4.3 & 3.3 & 3.8 & 3.2 \\
\hline
\end{tabular}

Source: EUROSTAT.

With regard to unemployment, Austria regionally performs quite balanced. With variation coefficients of 40.6 on the NUTS II level and 41.6 on the NUTS III level, Austria clearly lies below comparative EU-averages. Nevertheless, we notice a serious deterioration within the last years. Starting from $31 \%$ in 1999 the variation coefficient is now 41.8 on a NUTS III level. At the same time the EU-15 on an average improved in terms of regional homogeneity.

Table 44: Regional disparities of unemployment - Coefficients of variation ${ }^{128}$

\begin{tabular}{|l|rrrrrr|}
\hline NUTS II & 1999 & 2000 & 2001 & 2002 & 2003 & 2004 \\
\hline EU-25 & 56.4 & 62.3 & 66.0 & 63.8 & 59.4 & 55.8 \\
EU-15 & 60.7 & 65.3 & 64.9 & 60.1 & 56.0 & 51.2 \\
Austria & 28.5 & 33.4 & 35.8 & 42.8 & 42.6 & 40.6 \\
\hline NUTS III & 1999 & 2000 & 2001 & 2002 & 2003 & 2004 \\
\hline EU-25 & 60.5 & 66.1 & 70.1 & 67.9 & 63.5 & 62.0 \\
EU-15 & 65.2 & 69.7 & 69.1 & 64.1 & 60.1 & 55.4 \\
Austria & 30.9 & 36.0 & 39.3 & 44.0 & 43.7 & 41.8 \\
\hline
\end{tabular}

Source: EUROSTAT.

\section{Assessment of Measures of the Austrian NRP}

The Regional Growth and Employment Initiative (RGEI) is an investment programme with a regional component. It offers financial support based of soft loan credits and guarantees in connection with investment strategies by SMEs and larger enterprises in regions eligible for EU regional policy. To prevent deadweight effects, investment strategies have to be associated with the creation of additional jobs. Since subsidies only have to be associated with but not decisive for the creation of additional jobs, RGEI does not sufficiently prevent deadweight effects. The Austrian labour market shows a comparatively high degree of

\footnotetext{
${ }^{127}$ Standard deviation of employment divided by the national average (age group 15-64 years). (NUTS II).

${ }^{128}$ Standard deviation of unemployment divided by the national average (age group 15-64 years). (NUTS II).
} 
regional cohesion regarding employment and unemployment rates. Nevertheless, RGEI seems appropriate against the background of raising regional inequality in employment.

RGEI involves fund appropriations of 1.2 billion $€$. The Federal Government and the Länder at a ratio of 1:1 provide 370 million $€$ of that. The Austria Wirtschaftsservice $\mathrm{GmbH}$ (aws) supplements these grants by appropriate EU funds. Moreover ERP loans of 405 million $€$ are available, too.

The cash value of subsidies is considered to be 425 million $€$. RGEl is geared to activate an aggregated investment volume of 3 billion $€$. So far the RGEI has activated an investment volume of 3.3 billion $€ .85 \%$ of the projects and $70 \%$ of the subsidies concern SMEs. The AWS assumes that the implementation of RGEI has contributed to the establishment and protection of 100,000 jobs.

This result is again not consistent with net employment effects. The gross impact of investment programmes has to be put in the context of possible negative effects, such as displacement and deadweight-losses.

\section{Disadvantaged and disabled}

Against the background of increasing labour supply and social exclusion, the Lisbon Strategy wants to secure smooth transitions between the labour markets. This includes assistance for unemployed to ensure their employability and connection to the labour market in order to reintegrate them into the employment system once they became unemployed. Another focus is on prevention of social exclusion. Member States are requested to provide social services to support the inclusion of those "furthest away from the labour market and contribute to the eradication of poverty." Thus integration into the employment system and the provision of appropriate pathways into employment - even for occupationally disadvantaged groups - is seen as a major contribution to combat social exclusion and a pre-condition for socially inclusive societies. "Combating discrimination, promoting access to employment for disabled people, and integrating immigrants and minorities are particularly essential."

Corresponding indicators focus on long-term unemployment, the provision of preventative services and active labour market measures, on supply potentials in terms of the labour reserve as well as on the situation of specific groups like people with disabilities, non-EU nationals and disadvantaged people in general.

The Austrian situation is quite favourable in terms of long-term unemployment. Austria ranks among the countries with the lowest long-term unemployment rates: According to EUROSTAT data, the Austrian long-term unemployment rate was $1.3 \%$ in 2005 compared to an average of $3.9 \%$ for EU-25 and $3.3 \%$ for EU-15 respectively. 
The share of unemployed who have not benefited from counselling services and job-search assistance (both for youth and adults) is relatively low. Low values indicate an extensive provision of preventative services. Overall only Denmark, Sweden and Finland show even smaller shares. Austria is the country with the lowest shares of unemployed who have not benefited from active labour market measures.

Whereas the provision of labour market services and measures seems extensive, Austria ranks only $12^{\text {th }}$ among $19 \mathrm{EU}$ Member States with regard to active labour market expenditure as a percentage of GDP.

The number of inactive persons who want to work is reportedly relatively high: In 2005, the figure in Austria was $8.4 \%$, compared to EU-25 average at $5.2 \%$ and EU-15 average at $5.1 \%$. The Austrian labour reserve shows the second highest value behind Latvia, including inactive people not seeking employment and those that would like to work but cannot due to personal or family responsibilities or participation in education or training.

The unemployment rate gap between EU nationals and non-EU nationals is slightly above EU-25 and EU-15 average and has been increasing over recent years. In 2001 the unemployment rate gap was $5.2 \%$ compared to $8.9 \%$ for EU-15. In 2005 the corresponding value was $9.5 \%$, compared to $9.4 \%$ for EU-15. For the labour market integration of people at a disadvantage, no data is available.

\section{Assessment of Measures of the Austrian NRP}

The disability equality act introduces strengthened legislation regarding the discrimination of disabled workers. Among other things, it obliges employers to provide appropriate workplaces for people with disabilities.

Disability billion (employment initiative for people with disabilities): Within the scope of the employment initiative for people with disabilities, occupational integration of people with disabilities is supported. The "Billion for the disabled" provides incentives for integrating people with disabilities into the labour market in addition to the regular promotion schemes by the AMS and the Federal Social Welfare Office (Bundessozialamt). The focus is on the inclusion of young adults with disabilities into the labour market. The programme started in 2001. In 2004 17,486 individuals were subsidised which corresponds to an increase of $24.4 \%$ compared to the year before. 
Early notification system "Arbeitslosenfrühmeldung: In 2005, the AMS introduced an early notification system to provide measures for workers at risk of losing their job. The idea is to develop aid at the earliest possible point in time. In many cases, this is even before the transition into unemployment happens. Within the scope of the early intervention system, it is possible to develop early strategies regarding the re-integration of unemployed. Since intervention and job search assistance can improve matching between job seekers and vacancies, the system can be seen as positive contribution to employment and quality of allocation between employees and jobs in general. Furthermore early intervention may lead to a reduction of unemployment durations.

The Combined Wage Model provides employment possibilities for hard to place vacancies in the low wage bracket. According to AMS, about 5,000 job openings cannot be filled due to inadequate pay. If workers take up such marginal employment (wages below a threshold), they keep full benefit entitlement and receive a compensation payment from unemployment insurance. Hence, the formerly unemployed workers receive a wage subsidy equal to unemployment benefits in case he/she takes a marginal job. For the programme only persons aged below 25 or older than 45 qualify.

According to AMS data the take-up of the Combined Wage Model is more or less marginal (200 persons in 9/2006). One possible explanation for such low acceptance is the primarily relevance of the Combined Wage Model part-time employment. With regard to long-term unemployed, part-time employment is commonly associated with little acceptance, especially with regard to male job seekers. Furthermore the focus of the programme on specific age groups may also explain the low take up. 
Figure 29: Gender Pay Gap (2004)

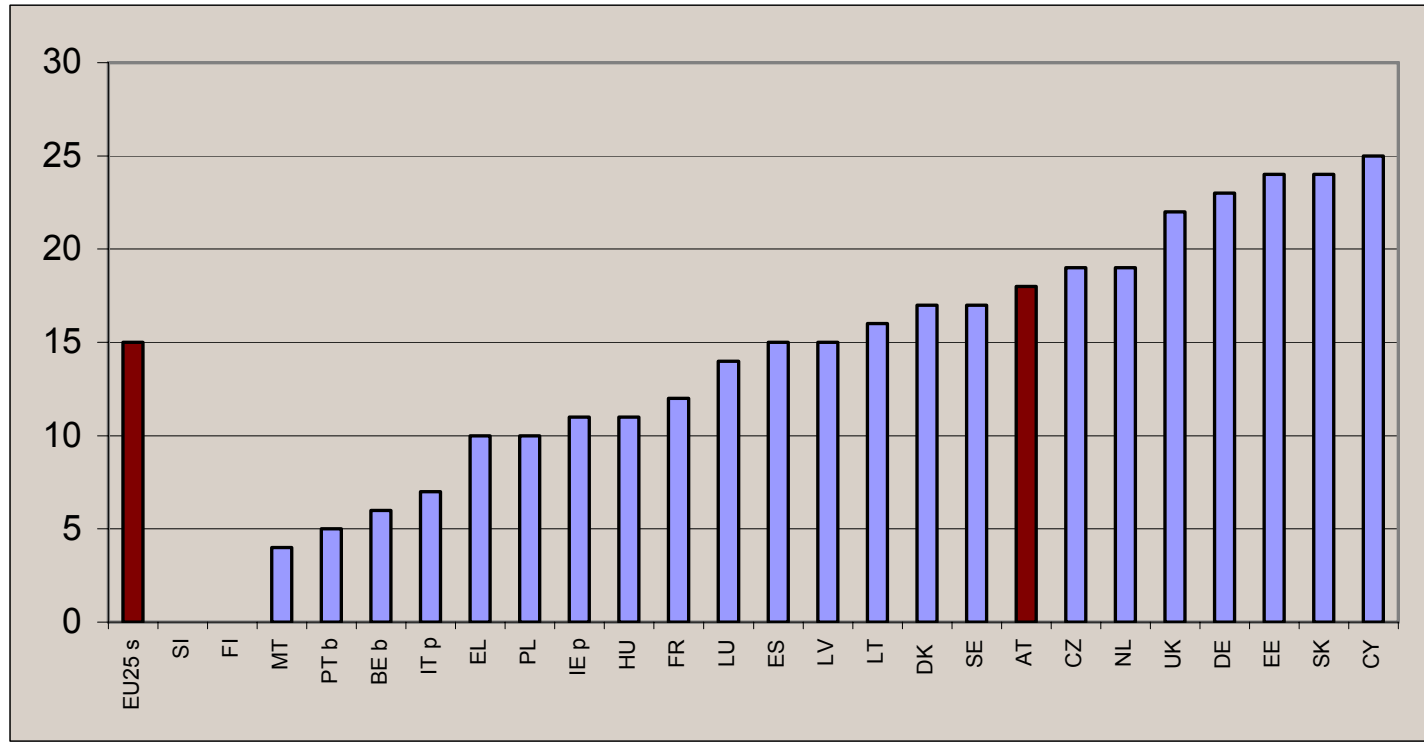

Source: EU Labour Force Survey

Notes: (1) Differenziert nach public-private sectors nur bis 2001 für einige Länder

The gender pay gap is given as the difference between average gross hourly earnings of male paid employees and of female paid employees as a percentage of average gross hourly earnings of male paid employees.

\section{Figure 30: Impact of parenthood (2005)}

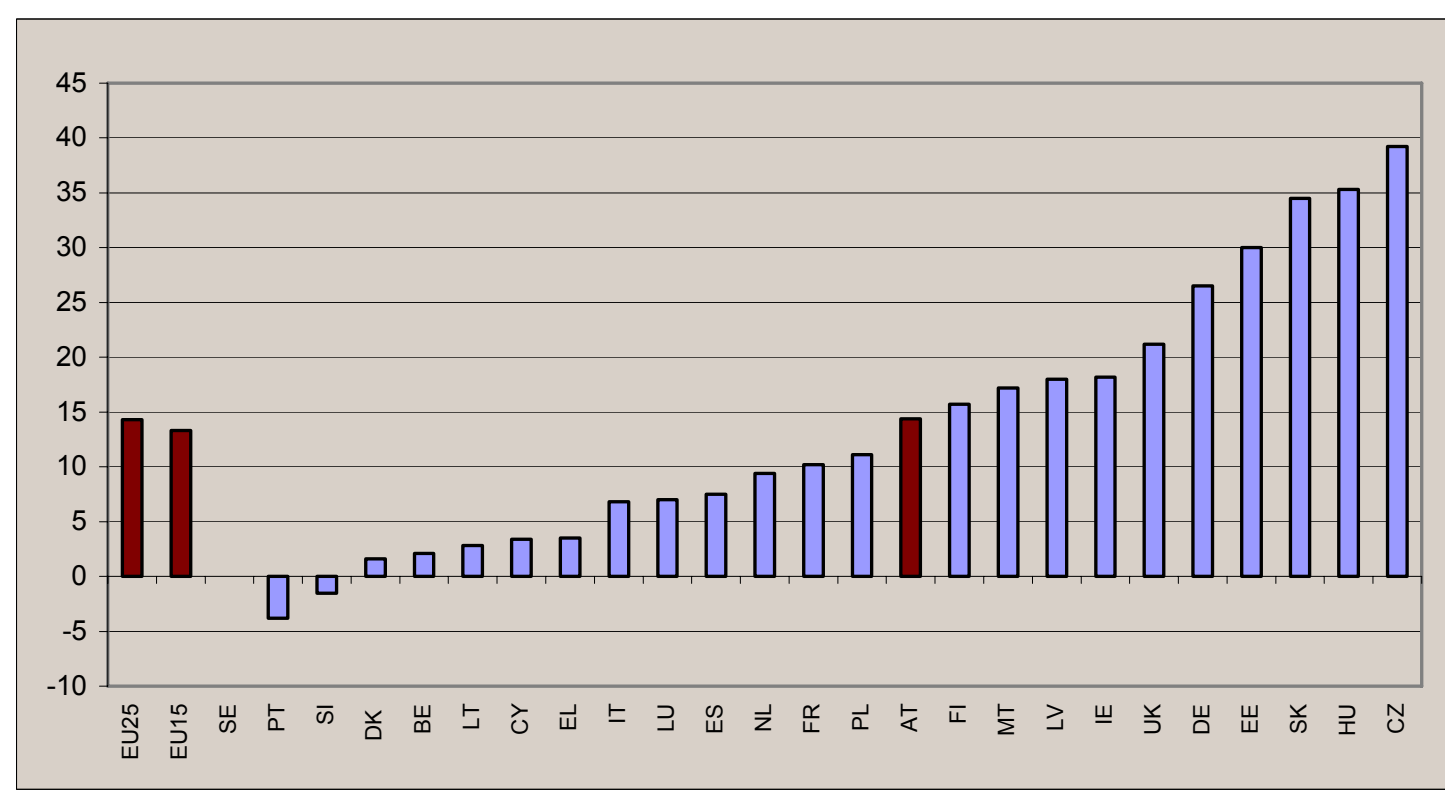

Source: Eurostat.

There is no data available for Sweden. 
Figure 31: Child care for children 0 to 2 years (2005)

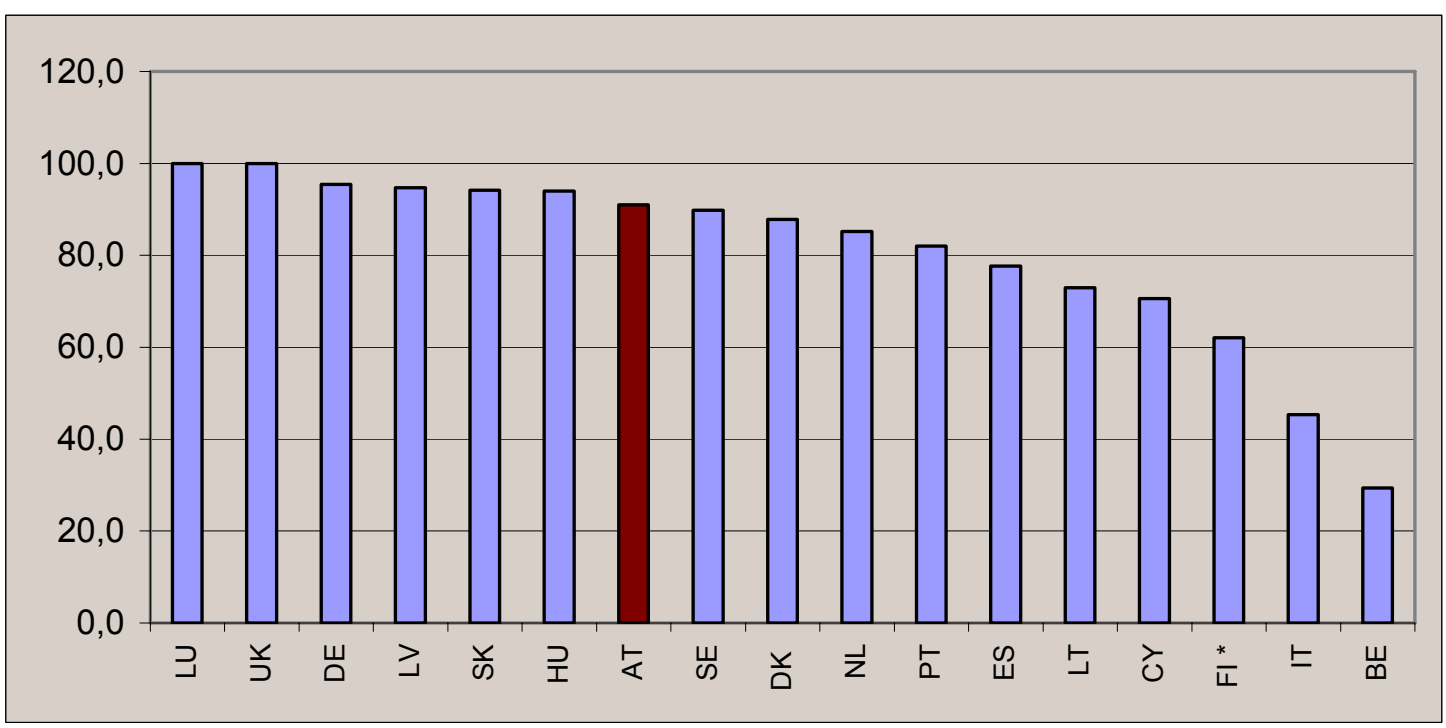

Source: Eurostat

There is no data available for EE, EL, IE, MT, PL and SI.

Figure 32: Number of Service Cheques sold per week (2006)

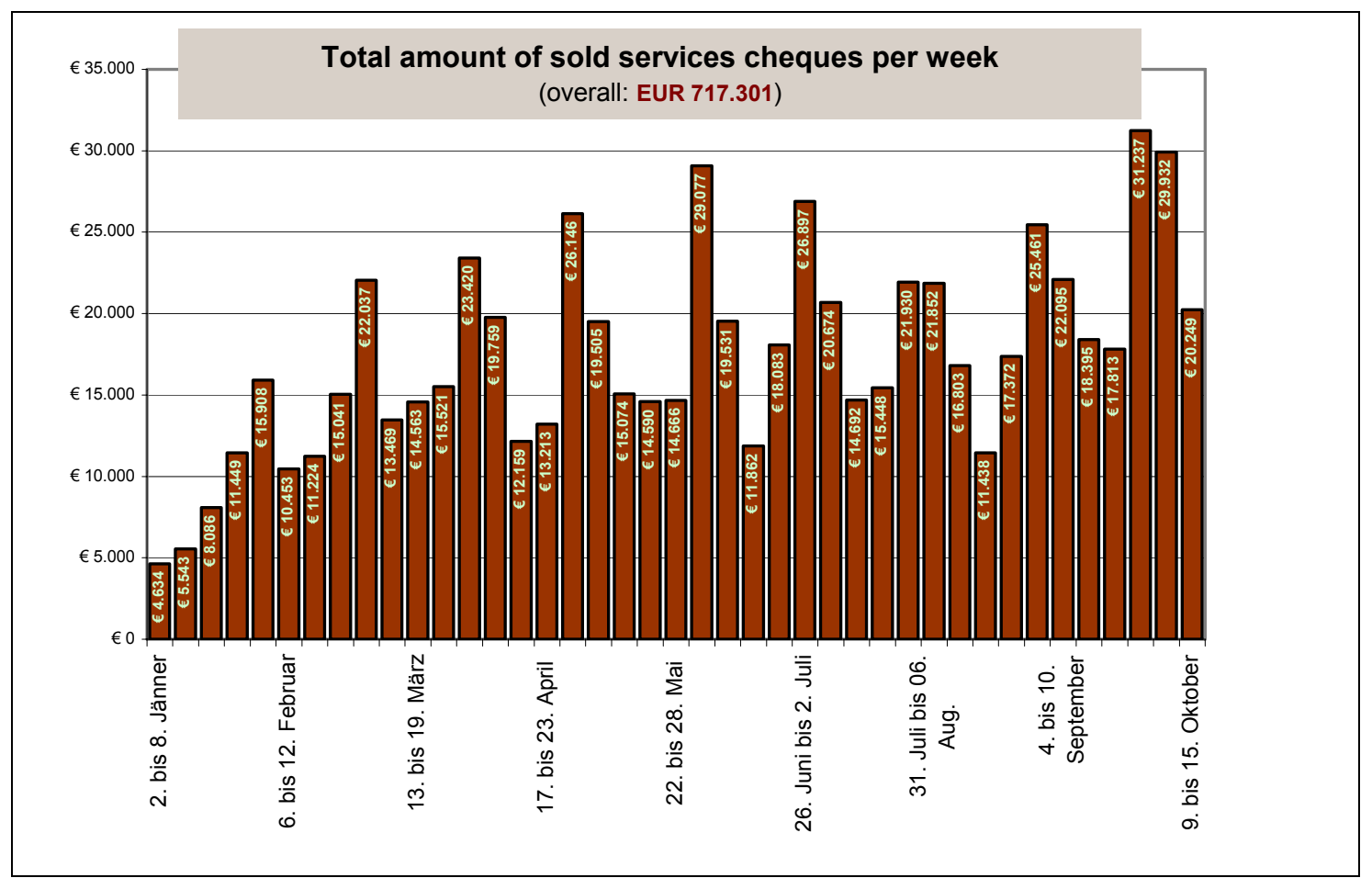




\subsection{Education and Further Training}

\section{Summary}

With respect to the main indicators used for education and further training, Austria performs well by EU comparison. Most Lisbon targets for 2010 already have been met in Austria.

According to available indicators, expenditures for as well as participation in education and further training in Austria do not seem to be problematic. Apparently, minor actions will be sufficient to ensure participation in further education and the attainment of 2010 targets. Taking into account that indicators used in this report rely on 1999 data and that, in the meantime, certain measures have been enacted, intervention may not be necessary at all if the mere goal is to reach 2010 targets.

Still, other European member states perform better than Austria, and orientation should always be towards the best. In Poland, for example, the percentage of early school leavers is only $5.5 \%$. If Austria tries to reach this benchmark by 2010 , additional efforts have to be made.

Measures in the context of education and further training definitely contribute to employment and growth, but in a more indirect way and with a mid-term perspective. Stronger emphasis on direct qualification measures, especially in the field of further training, and with respect to basic qualifications on upper secondary level in addition to the measures defined until now are expected to boost employment perspectives of participants and therefore produce a more direct effect on employment. 
Figure 33: Effects of NRP on Economic Interactions - Education and Further Training

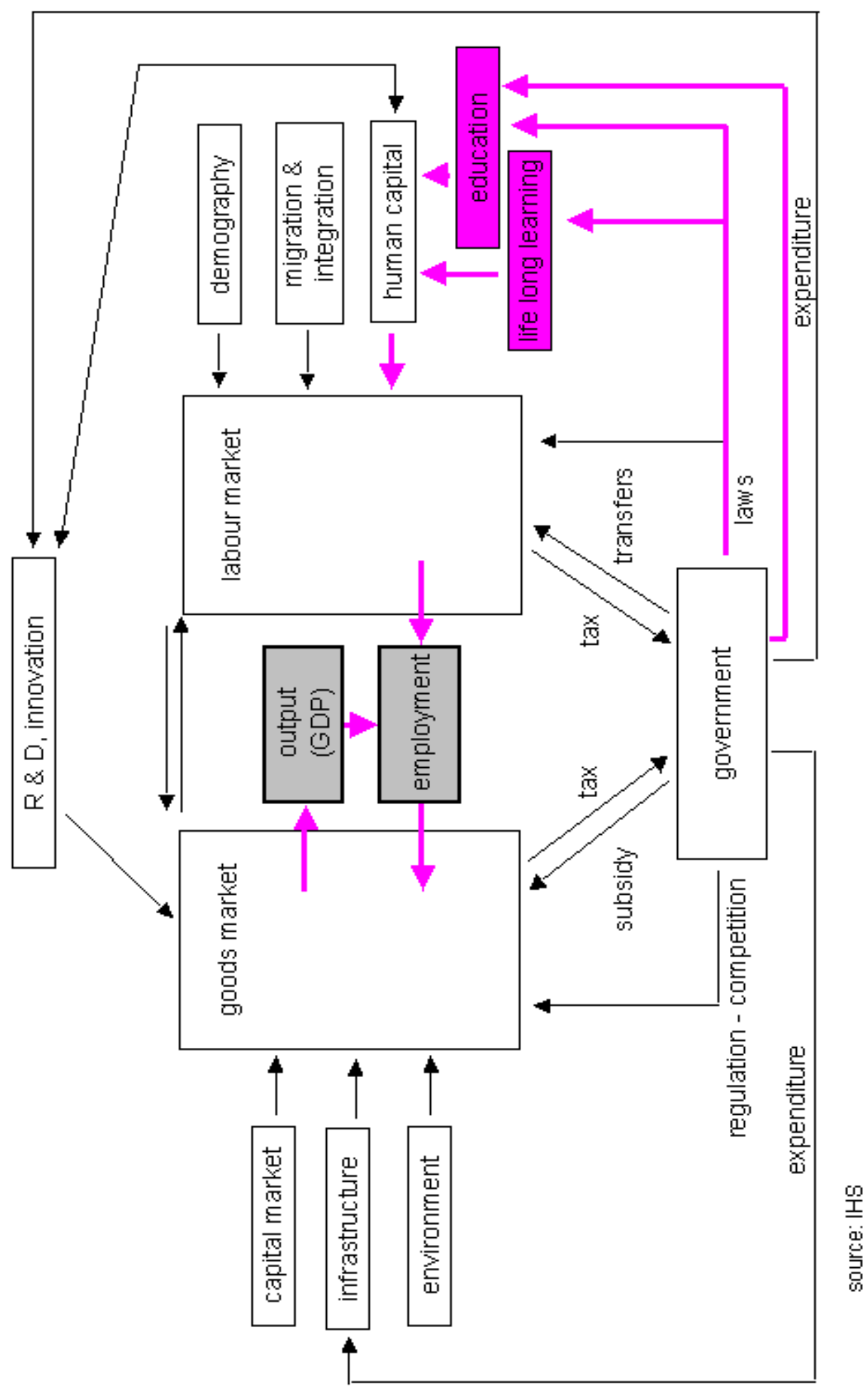




\section{Current Situation in Austria:}

As starting point for the evaluation of the Austrian strategy to tackle challenges in the field of education and further training, the Austrian situation is characterized by the indicators for monitoring employment guidelines. ${ }^{129}$

In Austria, investment in human resources, i.e. total public expenditure on education as a percentage of GDP, amounts to $5.48 \%$ of GDP. With EU-25 average at $5.21 \%$, public expenditure on education is slightly above average; private enterprise investment in continuous vocational training (CVT) in relation to labour costs is below average.

Educational attainment of 22 years old - percentage of the 20-24 age group having achieved at least upper secondary education (ISCED level 3): According to the most recent data available (2005), $85.9 \%$ of the Austrian population in this age group have achieved upper secondary education, whereas this is only true for $76.9 \%$ of all EU-25 citizens in the same age cohort. With this high level of educational attainment, Austria has already surpassed a 2010 benchmark in European employment strategy.

Early school leavers - percentage of 18-24 years old having achieved lower secondary education (ISCED level 2) or less, and not attending further education or training: Considering that in 2005 only $9 \%$ of the cohort dropped out of the Austrian school system before attaining education above ISCED 2 as compared to $15.2 \%$ on EU25 average, early school leaving does not seem to be a major problem in Austria. The EU benchmark of at most $10 \%$ early school leavers was has been attained in Austria since 2002.

Participation in education and training: Similar to education in general, further education and training - also referred to as life long learning (LLL) can hardly be referred to as problematic. The European 2010 benchmark for adult participation in education and training equals $12.5 \%$ (of the population between 25 and 64 years). In Austria, $13.8 \%$ of adults attend further education and training, whereas EU25 average amounts to only $11 \%$. The same is true for analyses by age group, working status or educational attainment.

Participation in CVT, i.e. share of employees in continuous vocational training (CVT): Corresponding to the lower investment of (private) enterprises in continuous vocational training, the share of Austrian employees participating in such training attains only $31 \%$ as compared to $39 \%$ on EU average.

To sum up, according to these indicators, expenditure for as well as participation in education and further training in Austria cannot be seen as problematic. Minor actions seem sufficient to ensure engagement in further education and the attainment of 2010 targets. Taking into account that above indicators rely on 1999 data and that, in the meanwhile, measures such as the increase of the training allowance from $9 \%$ to $20 \%$ should have some effect, intervention may not be necessary at al.

\footnotetext{
${ }^{129}$ EC (2006): Indicators for monitoring the Employment Guidelines, 2006 compendium, Brüssel.
} 
Yet, other European member states perform better than Austria, and orientation should always be towards the best. In Poland, for example, the percentage of early school leavers is only $5.5 \%$; if Austria tries to reach this benchmark by 2010 , additional efforts are necessary.

Figure 34: Austrian Performance in Further Education and Training

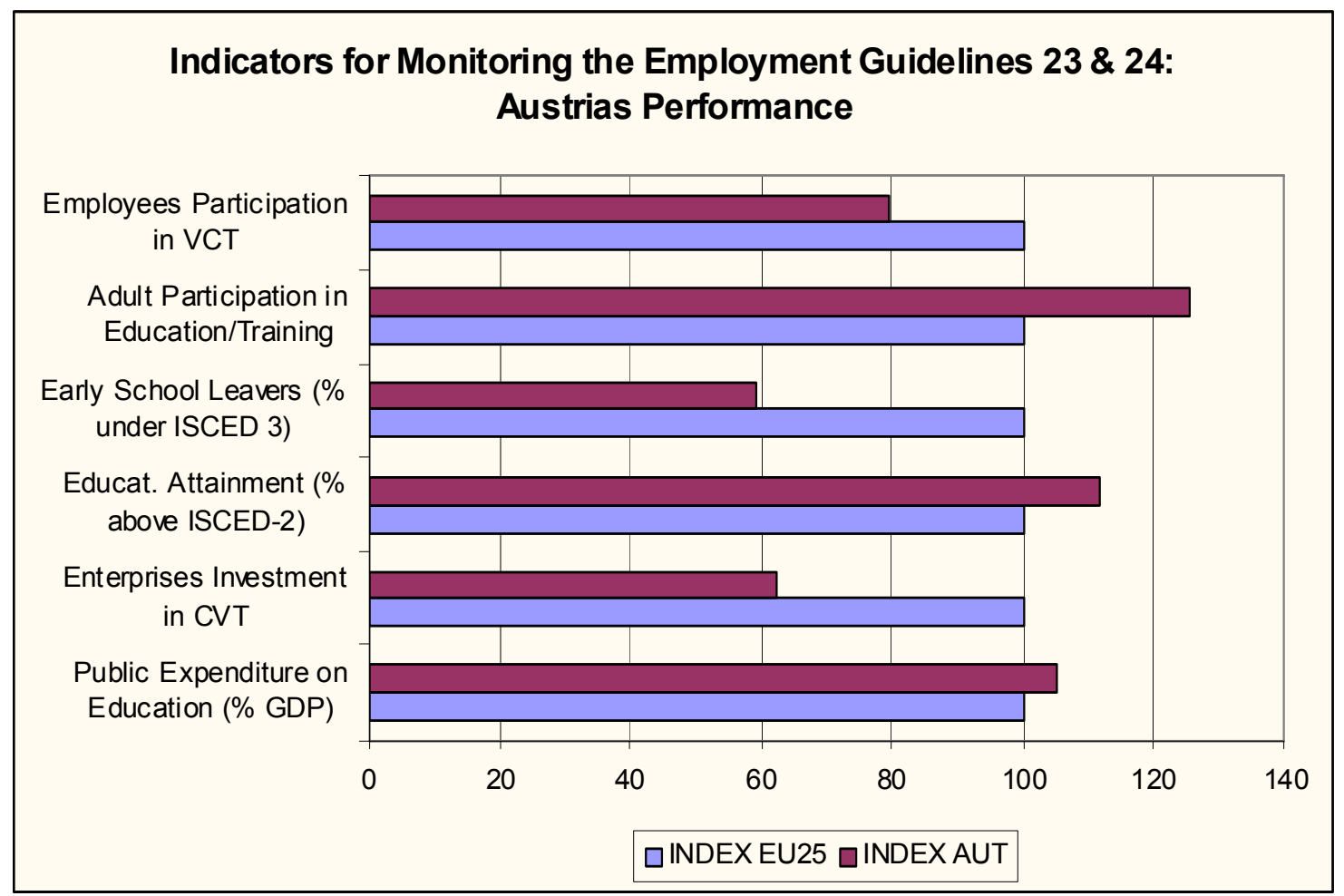

Source: EC (2006): Indicators for Monitoring the Employment Guidelines.

\section{Evaluation of NRP Measures:}

Within the education and further training guidelines, six measures are mentioned in the Austrian NRP, which will be discussed briefly with a special focus on resources invested and people affected.

The quality initiative for vocational schools (QIBB) is a quality network that forms the basis for safeguarding and further developing educational quality. "The cornerstones of quality management under QIBB are the systematic planning and agreement on objectives, regular evaluations, and outcome-based and objective-oriented reviews among management levels." The target is to establish not just a bundle of methods to support school management but a quality system "that addresses all stakeholders of the educational processes and reveals added value that is recognizable for everyone." ${ }^{130}$ QIBB is planned to

\footnotetext{
${ }^{130}$ BMBWK (2006): VET Quality Initiative. The Austrian VET Initiative to Assure and Further Develop Quality in the School-based Education System, Wien.
} 
be implemented in all vocational schools until 2008. If this target is reached $€ 4,84$ million will be spent in the school years 2006/07 and 2007/08 and 186.000 pupils and 16.000 teachers will be integrated in or affected by this measure.

Interface Education - Economy: School leaving certificates of higher and medium-level vocational schools (BMHS) have replaced the former business/entrepreneur exam (Unternehmerprüfung) which results in yearly 30.000 graduates leaving the educational system with this entrepreneurial potentials. Additionally, there is a new quality certificate for companies training students from vocational schools, a system that represents an integral part of vocational education. By 2008 , approx. $35 \%$ of all training companies should already be certified. No special budget is reserved for this initiative.

Promotion of Entrepreneurship: Initiated by ESF-Objective 3, the establishment of a new educational track 'entrepreneurship and management' within vocational business schools will be continued within NRP. Until 2008, approx. $40 \%$ of vocational business schools should offer this new educational branch that specializes in know-how on starting and managing companies. Apart from this special course, graduates of higher vocational business schools have always had classes in entrepreneurship in their regular curriculum. No additional budget is reserved for this initiative.

Agreement on social-care occupations: The target of this measure is a better recognition of occupations in care for elderly and disabled persons. Falling within the competence of the nine Austrian federal states, it is their task to issue rules on career profiles, fields of activity and vocational training in these occupations. Due to a national framework agreement on social-care occupations, the federal states are obliged to provide such rulings until mid 2007; in autumn 2006 none of the federal states had yet enacted such rulings.

The action Make up for Basic Qualifications encloses training courses to reach compulsory school-leaving certificates (ISCED 2). Participants also receive social support, language training and occupational orientation. 3.500 young people are expected to participate in the period of 2006-2008, the overall budget (including ESF) is 9.3 million $€$.

Amendment to the Vocational Training Act (Berufsausbildungsgesetz): The modular design of vocational training is expected to enable more employers to train apprentices and create conditions for better dove-tailing of initial and further training. The first two modularised apprenticeship-training-professions will start in 2007/08, another two in the subsequent year.

Measures in the context of education and further training mainly are structural and of qualitative nature; only two out of six represent concrete educational interventions for clearly specified target groups (basic qualifications, entrepreneurship and management). Otherwise, the focus is on structural changes in legal or organizational frameworks to create new opportunities or a better quality of education.

On the one hand, this strategic focus is consistent with the (above discussed) Austrian situation, where EU monitoring indicators show no heavy deficits concerning participation in 
and financing of education. If, on the other hand, Austria's orientation is towards the best performing EU-countries, additional effort - especially in the context of social cohesion (e.g. make up for basic qualifications) - is needed. Besides, and considering that further training (of employees) proved the weakest point, more emphasis should be laid on lifelong learning.

\section{Contribution to Employment and Growth:}

Based on economic theory, a population's and the employees' educational and qualificational attainments strongly contribute to employment and growth. In the context of global competition, highly industrialized regions find their advantage in the competence of human resources available on the labour market. A knowledge-intensive economy can only be built on the basis of highly qualified employees. Therefore, every measure improving education and key qualifications should contribute to both employment and growth, which will be argued (in more detail) below.

Quality initiative for vocational schools (QIBB): High qualification standards require high quality of education; measures that raise the quality of education are likely to lead to an improvement of education and to reduce dropout rates. This, in return, will contribute to the educational attainment of young cohorts. Following this chain of effects, the quality initiative for vocational schools will indirectly contribute to employment and growth.

Interface Education - Economy: The replacement of the former entrepreneur exam with the school leaving certificate for graduates of vocational schools eases the path for starting up businesses and independent employment. This increases the probability of more new companies and jobs. Therefore, this measure supports the NRP employment and growth goals in a medium-term perspective.

Promotion of Entrepreneurship: Entrepreneurial thinking is a key qualification for successful independent but also dependent employment. The promotion of entrepreneurship (as argued above) is expected to lead to increased business start-ups, the creation of new jobs and demand-tailored qualifications. In the context of modern management strategies, which are characterized by flat hierarchies and more autonomous teams of employees, an entrepreneurial way of thinking is required even in dependent employment. The promotion of entrepreneurship should also be considered for other professional fields (e.g. technical educations) to strengthen independent employment.

Agreement on social-care occupations: Due to population ageing and the rising share of older people, employment in social-care occupations will grow. A better recognition and higher quality of education in social care will raise its attractiveness and professionalism, which - in turn - will attract more students and result in a transfer of social care from unpaid family work to professional employment. On the basis of this argumentation, this measure is expected to contribute to NRP goals.

Make up for Basic Qualifications: The risk of unemployment grows with the lack of proper qualification. Making up for basic qualifications - like compulsory school-leaving certificates 
- rises the employability of workers and is an effective way to increase employment levels. The core result of the evaluation ${ }^{131}$ of the "make up for basic qualification"-measure was that its effect and effectiveness significantly rises with the intensity of intervention. A loss of intensity in favour of quantity decreases the effects. As unemployment rates significantly drop above ISCED-level 2, such measures should also include qualifications on upper secondary level.

Amendment to the Vocational Training Act: As knowledge base and economic structure develop very dynamically, it is essential for a good educational system to quickly react to changes in qualification demand. The amendment to the vocational training act eases such adaptation of the Austrian dual training system to economic changes through possible modularisations. This new attractiveness increases the number of apprenticeship places and thus contributes to employment. The first two modularised apprenticeship-training professions will start in autumn 2007, with contributions to employment to be expected thereafter.

To sum up, measures in the context of education and further training definitely contribute to employment and growth, but in a more indirect way and mid-term perspective. Stronger emphasis on direct qualification measures especially in the field of further training and basic qualifications on upper secondary level in addition to the measures defined until now are expected to boost employment perspectives of participants and therefore lead to a more direct effect on employment.

\footnotetext{
131 Steiner M., Wagner E., Pessl G. (2006): Evaluation der Kurse zum Nachholen des Hauptschulabschlusses [Evaluation of the courses to make up for die compulsory school leaving certificate], Study commissioned by the Federal Ministry of Education, Science and Culture, Vienna.
} 
Figure 35: Effects of NRP on Economic Interactions - Total Effect

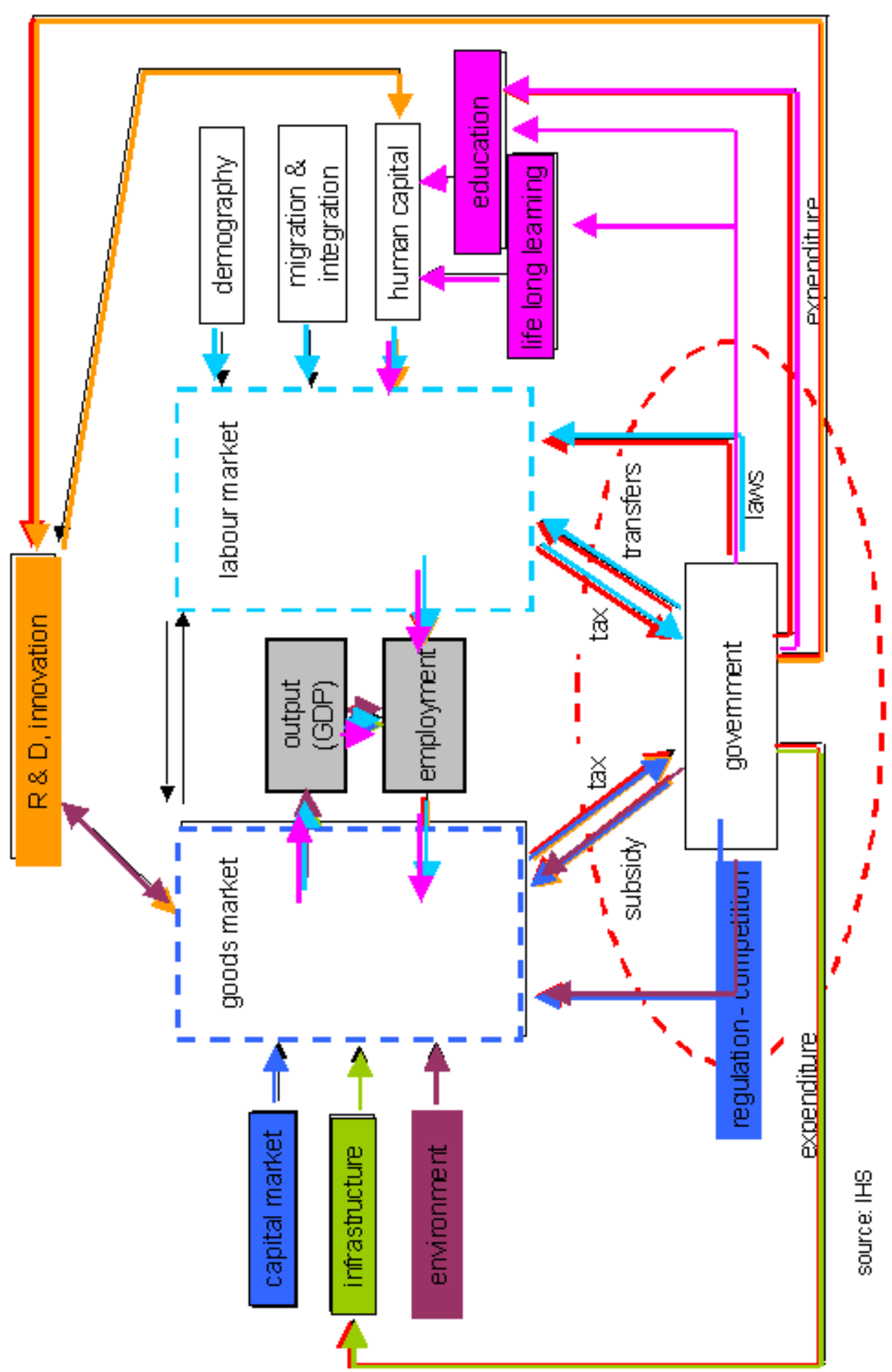


140 - Evaluation of NRP/I H S 


\section{ANNEX}

(1) More information on exports of goods, services and Austrian FDI

(2) TAXLAB - Dynamic Computable General Equilibrium Model for Austria 


\section{ANNEX 1: More information on exports of goods, services and Austrian FDI ${ }^{132}$} In 2005 the exports of goods reached a volume of 95.3 Bio. $€$. In the current year the export activity continued to expand by a growth rate of $9.7 \%$. Hence it might reach a volume of 104.6 Bio. $€$. The outlook for 2007 is also favourable. The Institute expects the real export growth to increase by $8.2 \%$.

In recent years the structure of the Austrian export sector has turned out to be an advantage. Despite the economic slump in the Euro region, the demand for cars and trucks was strong. The Austrian automotive industry, which accounts in 2006 for $41 \%$ in total goods exports, benefited from this development. The Austrian automotive industry is also successful because it provides solutions, which meet the requirements of the trading partners abroad, despite relatively high prices. Since the mid 1990s the commodity groups "food" and "beverages" increased their share in the Austrian export mix. In 2006 their share amounts to $6 \%$. The group of "manufactured goods" and "other final goods" have registered a loss in their export share. Trade surpluses have been generated by the automotive industry, by the sector of manufactured goods and by the category "beverages" (Table 45). The highest trade deficit is usually generated by the category "combustibles and energy".

Considering the Austrian goods exports by region, in 2006 the flows of goods to Eastern Europe, as well as to Asia, Russia and the Oil Exporting Countries turn out to be very dynamic. In addition the growth rate of the exports to the Eurozone is above the average of the past years. The countries of the Eurozone are the most important trading partners of Austria. However, in the last decade their influence declined. While at the beginning of the 1990s, $60 \%$ of the Austrian goods exports went to the Eurozone, the share declined to $48 \%$ in 2006 and it is already evident, that this development will continue in the near future. The Austrian goods exports to the new member countries of the EU have registered a strong upturn at the beginning of the 1990s. While in 1990 only $3 \%$ of all goods exports were directed to this country group, the share increased to $13 \%$ in 1997 . However in the following years, the share did not further expand. In contrast to this, other markets in Central and Eastern Europe have gained importance in the regional setting of the Austrian exports in the past years. The share of Austrian exports to North America accounts for $6 \%$ and it has duplicated in the last decade. In $20061.8 \%$ of the Austrian exports went to China. This number is still small, however, it is to be expected that the emerging economy will increase the demand for Austrian goods in the future (Table 46). The highest surplus in the Austrian

\footnotetext{
${ }^{132}$ References for Impact of openness on economic growth: Lee, H., Ricci, L. \& Rigobon, R. (2004). Once again, is openness good for growth, Working Paper 10749, NBER; Alcala, F., \& Ciccone, A. (2004): "Trade, and Productivity." Quarterly Journal of Economics, vol. 119, no. 2; , Institute for Advanced Studies (HIS, 2006), Austrian Economic growth forecast 2006-2007Quarterly report; OeNB (2006) Statistisches Monatsheft; OeNB (2006), Sonderheft Statistiken, Direktinvestitionen 2004; Statistik Austria (data) and OECD, Economic Outlook.
} 
foreign trade has been generated in the trade with North America and Southeast Europe. The highest deficit results in the trade with Germany.

The group of services exports consists of the business related services exports and the tourism exports. In 2005 the whole sector accounts for $14.1 \%$ of GDP, and amounted to 34.4 Bio $€$. While the share of the tourism sector in the total exports in services shows a steadily decline over time, the category of the business related services gained importance in the Austrian foreign trade.

The business related services comprise the branches of transport, communication, construction, insurance, finance, electronic data processing, patents and licenses, other trade services, operational leasing, knowledge based services, personal services and government services. With a share of $3.5 \%$ in GDP; the transportation sector is the most important sector among the business related services exports, followed by the knowledge based services exports, which have a share of $1.7 \%$. The insurance and financial services exports, with a share of 0.6 and 0.5 respectively, are relatively small (Table 17). However, in the previous years particularly high export rates generated from financial services, communication services and electronic data processing.

The tourism sector is gradually losing weight within the Austrian exports. While the city tourism and event tourism is gaining importance the demand for the traditional summer holiday has the tendency to shrink. However, due to the upturn of the business cycle in the neighbouring countries of Austria, the tourism exports will grow by $2.3 \%$ in the current year. Next year the growth will slow down again.

Although small, open economies show traditionally a clearly high degree of international integration, the Austrian investment ratios, inward and outward, are below the international standards. As recently as in the middle of the 1990s the foreign direct investments (FDI) in Austria started to gain importance. During the past ten years, the share of the passive FDI in GDP accounted for $2.2 \%$ of GDP on average. In 2003 the rate increased to $3 \%$. At the end of 2004, 234,800 persons have been employed in 2,667 foreign enterprises in Austria. The foreign flows of FDI to Austria have more than duplicated last year. They grew to 7.3 Bio. $€$, compared to 3.1 Bio. $€$ last year. Due to the upturn in the business cycle in the Eurozone, the FDI activities in Austria are likely to accelerate in the current and next year. With $81 \%$, the members of the Eurozone are the major investor countries in Austrian. Flows from Germany account for $44 \%$. Investments, which originate from Central and Eastern European countries, have a share of $3 \%$. Apart from social and economic stability, high security, central geographical position and quality of life, the good infrastructure, as well as the "Eastern" know-how of Austrian service providers are important reasons which influence the Central and Eastern Europe headquarters to move to Vienna in the future. 
The active FDI also gained importance in the middle of the 1990s. During the past ten years the share of the active FDI in GDP amounted to $2.1 \%$ on average. In the year 2005 the share increased to $3.3 \%$. At the end of $2004,370,500$ persons were employed in 2,727 Austrian FDI enterprises abroad. In 2005 the Austrian FDI flows abroad grew by $21 \%$ and increased to 8.1 Bio. $€$. According to a geographical breakdown, Central and Eastern Europe is the main target region for the Austrian FDI. This region receives $50 \%$ of the Austrian FDI in the past ten years. In 2006 their share may increase to $56 \%$. Since 2004 the Ukraine have turned out to be an attractive destination for Austrian investments. The countries of the Eurozone received only $20 \%$ of the Austrian FDI. The backflow of income, which generated form total Austrian FDI abroad accounted for a share of $2.3 \%$ in GDP, compared to $1.8 \%$ in 2006.

Table 45: Exports by commodity groups (in \%)

\begin{tabular}{|l|r|r|r|r|}
\hline & 2004 & 2005 & $2006^{*}$ & $2007^{*}$ \\
\hline & \multicolumn{2}{|c|}{ actual } & \multicolumn{2}{|c|}{ forecast } \\
\hline total & 100.0 & 100.0 & 100.0 & 100.0 \\
\hline food & 4.8 & 4.9 & 4.6 & 4.4 \\
\hline beverages & 0.6 & 0.5 & 0.5 & 0.5 \\
\hline raw materials & 3.4 & 3.8 & 3.7 & 3.7 \\
\hline combustibles, energy & 8.4 & 11.5 & 13.1 & 14.7 \\
\hline essential oils, and fats & 0.2 & 0.2 & 0.2 & 0.1 \\
\hline chemicals & 9.7 & 10.3 & 10.2 & 9.9 \\
\hline intermediate goods & 15.0 & 14.6 & 14.7 & 14.6 \\
\hline Automotive goods & 38.5 & 34.7 & 34.1 & 34.1 \\
\hline Other manuf. goods & 13.6 & 13.3 & 12.5 & 11.9 \\
\hline Stat. Differenz & 5.8 & 6.1 & 6.4 & 6.1 \\
\hline
\end{tabular}

Sources: Statistik Austria; *) IHS-Forecast. 
Table 46: Exports by partner countries and regions (in \%)

\begin{tabular}{|c|c|c|c|c|}
\hline & 2004 & 2005 & $2006^{*}$ & $2007^{*}$ \\
\hline & \multicolumn{2}{|c|}{ actual } & \multicolumn{2}{|c|}{ forecast } \\
\hline Total & 100.0 & 100.0 & 100.0 & 100.0 \\
\hline Europe & 79.1 & 78.4 & 76.6 & 73.5 \\
\hline Africa & 1.1 & 1.1 & 1.2 & 1.1 \\
\hline America & 7.2 & 7.0 & 7.0 & 7.1 \\
\hline Asia & 5.9 & 6.0 & 6.3 & 6.2 \\
\hline Australia & 0.6 & 0.6 & 0.7 & 0.7 \\
\hline EU & 67.8 & 67.0 & 65.4 & 62.9 \\
\hline Eurozone & 50.2 & 49.6 & 48.4 & 46.3 \\
\hline MOEL1) & 9.6 & 9.6 & 9.6 & 10.0 \\
\hline EFTA (excl. EU) & 4.6 & 4.6 & 4.3 & 4.0 \\
\hline Southeast Europe & 3.7 & 3.5 & 3.5 & 3.6 \\
\hline North America & 6.4 & 6.1 & 6.1 & 6.0 \\
\hline South America & 0.8 & 0.9 & 0.9 & 0.9 \\
\hline Tiger states & 1.7 & 1.7 & 1.9 & 1.9 \\
\hline Middle East & 1.2 & 1.4 & 1.5 & 1.5 \\
\hline Germany & 30.4 & 29.9 & 29.0 & 27.6 \\
\hline France & 4.0 & 4.0 & 3.8 & 3.8 \\
\hline Italy & 8.1 & 8.1 & 8.2 & 7.9 \\
\hline UK & 4.0 & 3.8 & 3.7 & 3.5 \\
\hline Switzerland & 4.2 & 4.2 & 4.0 & 3.7 \\
\hline USA & 5.6 & 5.3 & 6.0 & 5.9 \\
\hline Japan & 1.1 & 1.0 & 1.0 & 0.9 \\
\hline Hungary & 3.5 & 3.2 & 3.2 & 3.3 \\
\hline Poland & 1.7 & 1.9 & 2.0 & 2.1 \\
\hline Czech Republic & 2.9 & 2.9 & 2.8 & 2.8 \\
\hline Russia & 1.5 & 1.7 & 2.0 & 2.3 \\
\hline China & 1.2 & 1.2 & 1.8 & 2.1 \\
\hline
\end{tabular}

Sources: Statistik Austria; *) IHS-Forecast, 1) MOEL consists of Hungary, Poland, Czech Republic and Slovakia. 


\section{ANNEX 2: TAXLAB - Dynamic Computable General Equilibrium Model for Austria $^{133}$}

The simulations in the chapters on macro policy and better regulation (Table A, Table 25) have been carried out by means of TAXLAB, a dynamic computable general equilibrium model for Austria. TAXLAB is used for political advice and for the evaluation of reform proposals.

TAXLAB is a growth model for Austria. It is a small open economy model, which implies that the international capital markets determine the domestic real interest rate and goods prizes are given. The model consists of an intertemporally optimizing production sector. Inputs of the production sector are capital, which is fully mobile, and three different skills of labour. The production function allows for the feature of capital-skill complementarity. The firms maximize their profits by optimizing investment and their number of vacancies.

The structure of the household sector is based on the idea of overlapping generations like in the OLG models of Blanchard (1985) and Gertler (1999). The concept used in the model is similar to the concept of Probabilistic Aging described by Grafenhofer et al. (2005). The population is divided into ten different age groups with seven working generations and three generations of retirees. Furthermore, households differ with respect to the education level, with low-, medium- and high-skilled households. Individuals of the different groups differ with respect to numerous properties, like e.g. the probability of dying, labour productivity and the share of health costs in the public sector.

The model incorporates a search-theoretical labour market with a matching function that brings together vacancies of the firms and unemployed individuals. It allows for age- and education-dependent unemployment rates. The retirement decision and the decision to participate in the labour market are modelled endogenously. Age- and skill-dependent productivities lead to life cycle and skill-dependent earnings.

TAXLAB models the public sector in a detailed way. It distinguishes between the social security sector on the one hand and the public sector in a narrow sense on the other hand. All important taxes and social security contributions are included in an explicit way whereas some less important taxes enter in an aggregate manner. The expenditure side of the public sector takes into account transfers, public services, social security expenditures and the accumulation of public debt.

\footnotetext{
${ }^{133}$ Blanchard, Olivier J. (1985). Debt, Deficits and Finite Horizons, Journal of Political Economy 93, S. 223-24; Gertler M. (1999): Government Debt and Social Security in a Life-Cycle Economy. Carnegie-Rochester Conference Series on Public Policy 50, S. 61-110; Grafenhofer D., Jaag C., Keuschnigg C., Keuschnigg M. (2006): Probabilistic Aging. CESifo Working Paper No. 1680; Ministry of Finance of Netherlands (2005). Reducing administrative burdens: now full steam ahead, Den Haag, www.compliancecosts.com.
} 


\section{Bibliography}

Aghion, P., Howitt, P. (1998): "Endogenous growth theory", Cambridge, MA. MIT Press.

Alcala, F., \& Ciccone, A. (2004): "Trade, and Productivity." Quarterly Journal of Economics, vol. 119, no. 2, May 2004, pp. 613-46.

AM (Danish Ministry of Labour) (2000): Effects of Danish employability enhancement programmes, Copenhagen.

Austrian Institute for Familiy Studies (ÖIF, 2006): 4 Jahre Kinderbetreuungsgeld. Ergebnisse der begleitenden Evaluierung im Auftrag des Bundesministeriums für Soziale Sicherheit, Generationen und Konsumentenschutz, 9. Mai 2006 (Presseinformation).

Bassanini A. and Duval R. (2006): Employment patterns in OECD countries: Reassessing the role of policies and institutions. in: OECD: Economics Department Working Papers. No. 486: Paris 2006.

Beer, Ch. et al. (2004): Ökonomische Wirkungen aktueller Steuerreformmaßnahmen. IHS Research Report.

Bencivenga, Valerie R. und Bruce D. Smith (1991): Financial Intermediation and Endogenous Growth, Review of Economic Studies, 58, pp. 195-209.

Bernanke Ben S. (2006): address delivered at Massachusetts Institute of Technology (MIT), June 9, 2006.

Blanchard, Olivier J. (1985): Debt, Deficits and Finite Horizons, Journal of Political Economy, 93, pp. 223-247.

BMBWK (2006): VET Quality Initiative. The Austrian VET Initiative to Assure and Further Develop Quality in the School-based Education System, Wien.

BMF (2005): Austrian Stability Programme. Update for the period 2005 to 2008.

BMLFUW (2002), "Strategie Österreichs zur Erreichung des Kyoto-Ziels. Klimastrategie 2008/2012", BMLFUW Abt, V/4, 2002, in: http://www.lebensministerium.at.

BMLFUW (2005): “ETAP Roadmap 2005”, in: www.lebensministerium.at.

BMLFUW (2005): „Österreichs JI/CDM-Programm 2005 Joint-Implementation-/CleanDevelopment-Mechanism-Programm, in: http://www.ji-cdm-austria.at.

BMLFUW (2006): "Environmental technologies - Innovations from Austria", 2006, in: www.lebensministerium.at.

BMVIT (2002): Generalverkehrsplan Österreich 2002, Verkehrspolitische Grundsätze und Infrastrukturprogramm, Januar 2002.

BMWA (2004): Arbeitsmarktmonitoring 2004.

BMWA (2005),::Arbeitsmarkt und Arbeitsmarktpolitik in Österreich.

BMWA (2006): „Österreichisches Reformprogramm für Wachstum und Beschäftigung“, Wien.

BMWA (2006): Labour Market Monitoring 2004/2005 based on the Data Warehouse of the Public Employment Service Austria, Vienna.

BMWA und BMF (2006): Wirtschaftsbericht Österreich 2006, Wien. 
Bodenhöfer, H. J. et al. (2004): Bewertung der volkswirtschaftlichen Auswirkungen der Unterstützung von Ökostrom in Österreich. Forschungsbericht IHS Kärnten.

Breuss, F., Kaniovski, S., Schratzenstaller, M. (2004): Steuerreform 2004/05 - Maßnahmen und makroökonomische Effekte. WIFO-Monatsbericht 8/2004.

Bundesregierung - „Die österreichische Strategie zur Nachhaltigen Entwicklung“. Initiative der Bundesregierung, in: http://www.nachhaltigkeit.at/strategie/pdf/strategie020709 de.pdf

Bundesregierung (2006): Österreichisches Reformprogramm für Wachstum und Beschäftigung, 1. Umsetzungsbericht, Version 25.09.2006, Wien.

Burger Christina and Bernhard Felderer (2005): Forschung und Entwicklung: Wirkungen auf Wachstum, Beschäftigung und Wohlfahrt, Hintergrundpapier des Instituts für Höhere Studien im Auftrag der Forschungsförderungsgesellschaft mbH.

Capgemini (June 2006): Online Availability of Public Services: How Is Europe Progressing? Web Based Survey on Electronic Public Services.

Carlin, Wendy and Colin Mayer (2000): How do financial systems affect economic performance?, in X. Vives (ed.), Corporate Governance: Theoretical and Empirical Perspectives, New York: CUP, 137-168.

Carlin, Wendy und Colin Mayer (2003): Finance, investment, and growth, Journal of Financial Economics, 69, 191-226.

Denny, K., et al. (2000): Investing in people: The labour market impact of human resource interventions funded under the 1994-1998 community support framework in Ireland, ESRI Policy Research Series 38, Dublin.Jorgenson; Dale (2006) on "Information Technology and the World Economy", and other contributions to the "Determinants of Productivity Growth", special Issue of the German Economic Review (forthcoming).

Dunning J. H. (1979): "Explaining Changing Patterns of International Production: In Defence of the Eclectic Theory", Oxford Bulletin of Economics and Statistics, 41, 1979, pp. 269295.

ECOTEC Research and Consulting Ltd., "Analysis of the EU eco-industries, their employment and export potential", A Final Report to DG Environment, Birmingham, 2002.

eGovernment economics project (eGEP): Project for the European Commission, DG Information Society and Media. 2006. http://217.59.60.50/eGEP/Static/E Description.asp.

Ekholm, K. (2003): "Industrial Structure and Industry location in an Enlarged Europe", Swedish Institute for European Policy Studies, 2003.

Energie-Control GmbH (2005): "Bericht über die Ökostrom-Entwicklung und fossile KraftWärme-Kopplung in Österreich“, gemäß § 25 Abs 1 Ökostromgesetz (BGBI I Nr 149/2002)" zur Vorlage beim Bundesminister für Wirtschaft und Arbeit und beim Elektrizitätsbeirat, Juni 2005 mit Ergänzung der Halbjahresdaten 2005 im August 2005, in: http://www.e-control.at.

EU (2006): Science and Technology in Europe, in: http://epp.eurostat.ec.europa.eu/cache/ITY OFFPUB/KS-EA-06-001/EN/KS-EA-06-001-EN.PDF.

European Commission (2003): Observatory of European SMEs 2003, No. 8 , http://ec.europa.eu/enterprise/enterprise policy/analysis/doc/smes observatory $2003 \mathrm{r}$ eport8 en.pdf. 
European Commission (2003): Observatory of European SMEs 2003, No. 2, SMEs and Access to Finance,

http://ec.europa.eu/enterprise/enterprise policy/analysis/doc/smes observatory $2003 \mathrm{r}$ eport2 en.pdf.

European Commission (2004): A report on the functioning of public procurement markets in the EU: benefits from the application of EU directives and challenges for the future, p. 5. http://ec.europa.eu/internal market/publicprocurement/docs/public-proc-marketfinal-report en.pdf

European Commission (2005): "Doing more with less. Green paper on energy efficiency", in: http://ec.europa.eu/energy.

European Commission (2005): "Taxation, Employment and Environment: Fiscal Reform to reducing unemployment", Brussels, 2003, cited from Luptacik M., Weiss Ch., Vorstudie: "Produktivität und Ökoeffizienz", Wirtschaftsuniversität Wien, 10 January 2005.

European Commission (2005): Yearly assessment of Austrian situation as to Lisbon targets.

European commission (2006): "Analysis of the Austrian National Reform Programme for Growth and Jobs," in: http://ec.europa.eu.

European Commission (2006): documents on the transposition of FSAP directives (Oct 9, 2006) at http://ec.europa.eu/internal market/finances/actionplan/transposition.

European Commission (2006): Economic forecasts, European Economy 2/2006.

European Commission (2006): Public Finances in EMU 2006, European Economy 3/2006.

European Commission (2006): The long-term sustainability of public finances in the European Union. European Economy 4/2006.

European Commission (2006): Consultative Paper on SEPA Incentives, February 13, 2006.

European Commission (2006): Indicators for monitoring the Employment Guidelines, compendium, Brüssel.

European Commission Green Paper: Damages Actions for Breach of the EC Antitrust Rules, Brussels (Dec. 19, 2005), SEC (2005) 1732,

http://europa.eu.int/comm/competition/antitrust/others/actions for damages/gp en.pdf

European Commission (2006): Effective European Active Labour Market Policies. In: European Commission. Employment in Europe, 2006, p. 119 -172.

EU Commission Staff Paper (2006): 30 June 2006, Brussels.

European Concil (2005): Presidency Conclusions of EC in Bruxelles, 22 \& 23 March 2005, in: http://ec.europa.eu/growthandjobs/councils en.htm.

European Concil (2006): Presidency Conclusions of EC in Bruxelles, 18 May 2006, in: http://www.consilium.europa.eu/ueDocs/cms Data/docs/pressData/en/ec/89013.pdf.

European Council (2000): Presidency Conclusions, Lisbon European Council, 23 \& 24 March 2000, in: http://consilium.europa.eu/ueDocs/cms Data/docs/pressData/en/ec/00100-r1.en0.htm.

European Council (2006): Schlussfolgerungen des Vorsitzes, Europäischer Rat in Brüssel am 23/24 März 2006, document 7775/01/06, rev. 1, in:

http://www.eu2006.at/de/News/Council Conclusions/2403EuropeanCouncil.pdf. 
European Innovation Scoreboard 2005, in: http://trendchart.cordis.lu/scoreboards/scoreboard2005/executive summary.cfm.

EUROSTAT data, extraction August and October 2006, in: http://epp.eurostat.ec.europa.eu.

Eurostat, 08/2006: Statistik Austria, Yearbook 2006; information from Austrian Federal Ministry of Agriculture, Forestry, Environment and Water Management, Oct. 2006.

Fay, Robert F. (1996): Enhancing the Effectiveness of Active Labour Market Policies: Evidence from Programme Evaluations in OECD-Countries. in: OECD (1996): Labour Market and Social Policy, Occasional Papers No. 18: Paris.

Felderer, B., Graf, N., Paterson, I., Polasek, W., Schwarzbauer, W., Sellner, R. (2005): The European Services Market in the Context of the Lisbon Agenda - Productivity and Employment in European Services with high Intensity of Information and Communications Technology (ICT) - Study commissioned by the Federal Chancellery of Austria.

FFG (2006): homepage for COMET and COMET presentation paper, in: http://www.ffg.at/content.php?cid=352.

Financial Services (1999): Implementing the Framework for Financial Markets: Action Plan, COM (1999) 232, 11.5.1999.

FOFO.S, SELF-EMPLOYMENT, ongoing research project, http://www.fofos.at/downloads/4497116814e5b.pdf.

Forslund, A., Krueger, A. B. (1994): An Evaluation of the Swedish Active Labour Market Policy: New and Received Wisdom, Working Paper No. 4802, National Bureau of Economic Research.

FSAP Evolution Chart, http://ec.europa.eu/internal market/finances/actionplan/index en.htm\#transposition

Gertler M. (1999): Government Debt and Social Security in a Life-Cycle Economy. CarnegieRochester Conference Series on Public Policy 50, pp. 61-110.

Grafenhofer D., Jaag C., Keuschnigg C., Keuschnigg M. (2006): Probabilistic Aging. CESifo Working Paper No. 1680.

Greenwood, Jeremy und Boyan Jovanovic (1990): Financial Development, Growth, and the Distribution of Income, Journal of Political Economy, 98, 1076-1107.

Grubb, D., Martin, J.P. (2001): What Works and for Whom? A Review of OECD Countries' Experiences with Active Labour Market Policies, Swedish Economic Policy Review 8.

Guellec D. and Pottelsberghe B. (2001): R\&D productivity growth: panel data analysis of 16 OECD countries, OECD STI working paper 2001/3, Paris.

Häder M., Schulz E. (2005): “Renerative Energien”, Energiewirtschaftliche Tagesfragen, Vol. 7.

Heady C.J. et al. (2000): "Study on the relationship between environmental/energy taxation and employment creation", Report for the European Commission, University of Bath.

Hicks, J. (1935): "Annual Survey of Economic Theory: the Theory of Monopoly," Econometrica, Vol. 3, pp. 1-20.

Hofer H. and Weber A. (2006): Active Labor Market Policy in Austria: Practice and Evaluation Results, in: Vierteljahrshefte zur Wirtschaftsforschung, 75. 
Hofer H., Ragacs C., Riedel M., Schuh U., Wörgötter C. (2003): Qualität der Arbeit ökonomische Theorie und wirtschaftspolitische Implikationen, Institut für Höhere Studien, Wien, p. $64 \mathrm{ff}$.

IHS (2006): Prognose der österreichischen Wirtschaft 2006-2007, Oktober 2006.

Institute for Advanced Studies (IHS): Austrian Economic growth forecast, 2006-2007, Quarterly report, October 2006. http://www.ihs.ac.at/index.php3?id=1064.

King, Robert and Ross Levine (1993): Finance and Growth, Schumpeter Might Be Right, Quarterly Journal of Economics, 108, 717-737.

King, Robert und Ross Levine (1993): Finance, Entrepreneurship and Growth: Theory and Evidence, Journal of Monetary Economics, 32, 513-542.

Kluve, J. (2006): The Effectiveness of European Active Labour Market Policy. IZA Discussion Paper 2018. Bonn.

Kok W. (2004): „Die Herausforderungen Annehmen. Die Lissabon-Strategie für Wachstum und Beschäftigung. Bericht der Hochrangiger Sachverständigengruppe unter Vorsitz von Wim Kok", Luxembourg.

Köppl A. (2006): "The Austrian Environmental Industry. Summary of results", WIFO, Österreichisches Institut für Wirtschaftsforschung, February 2006.

KPMG (2006): Corporate Tax Rates Survey 2006, in: http://www.kpmg.com/Services/Tax/IntCorp/CTR/EU.htm (17 October 2006)

Lee, H., Ricci, L. \& Rigobon, R. (2004): Once again, is openness good for growth, Working Paper 10749, NBER.

Levine, Ross (1997): Financial Development and Economic Growth, Views and Agenda, Journal of Economic Literature, 35(2), 688-726.

Luptacik M., Weiss Ch. (2005): Vorstudie: "Produktivität und Ökoeffizienz", Wirtschaftsuniversität Wien, 10 Jänner 2005.

Lutz H. (2003): Auswirkungen der Kindergeldregelung auf die Beschäftigung von Frauen mit Kleinkindern, in: WIFO-Monatsberichte 3/2003, pp. 213-227.

Lutz, H., et al. (2005): Schwerpunkt 1: Verhinderung und Bekämpfung der Langzeitarbeitslosigkeit und der Jugendarbeitslosigkeit. In: WIFO, IHS, L\&R: Evaluierung Europäischer Sozialfonds 2000-2006, Ziel 3: Österreich, pp. 85-106.

Mansfield, E. (1996): "Contributions of New Technology to the Economy", in B. Smith and C. E. Barfield (eds), Technology, R\&D \& the Economy. Washington, D.C.: Brookings Institution and American Enterprise Institute.

Merton, Robert C. und Zvi Bodie (1995): A Conceptual Framework for Analyzing the Financial System, in Dwight B. Crane et al. (eds.): The Global Financial System: A Functional Perspective, Boston, MA: Harvard Business School Press.

Ministry of Finance of Netherlands (2005): Reducing administrative burdens: now full steam ahead, Den Haag, www.compliancecosts.com.

Mourre, G. (2006): Did the pattern of aggregate employment growth change in the euro area in the late 1990s? in: Applied Economics, 2006, 38, pp. 1783-1807. 
NERA Economic Consulting (2005): The Future of Clearing and Settlement in Europe, City Research Series 7, London and The Giovannini Group (2001): Cross-Border Clearing and Settlement Arrangements in the European Union, Brussels.

Nicolleti G. and S. Scarpeta (2005): Product Market Reforms and Employment in OECD Countries, OECD Economics Department Working Papers No. 472.

O'Mahony, M. and van Ark, B. (ed.) (2003): EU productivity and competitiveness: An industry perspective - Can Europe resume the catching-up process?, European Commission.

OECD (2000): "Greening tax mixes in OECD countries: a preliminary assessment"

OECD (2003): OECD Economic Survey of Austria 2003: Pensions.

OECD (2003): The sources of economic growth in OECD countries, Paris.

OECD (2003): ICT and Economic Growth. Evidence from OECD Countries, Industries and Firms. Paris.

OECD (2004): The Economic Impact of ICT - Measurement, Evidence \& Implications, Paris.

OECD (2005): Employment Outlook.

OECD (2006): Economic Outlook, http://www.oecd.org/statisticsdata/0,2643,en 2649341091111965611 1,00.html.

OECD (2006): Factbook 2006: Economic, Environmental and Social Statistics. OECD Paris.

OECD (2006): OECD Employment Outlook, in: http://www.oecd.org/statisticsdata.

OECD: Glossary of Industrial Organisation Economics and Competition Law.

OeNB (2006): Sonderheft Statistiken, Direktinvestitionen 2004, September 2006.

OeNB: Statistisches Monatsheft, available at http://www.oenb.at/de/suchergebnis.jsp?p Query=dienstleistungen\&p Action=OK\&p Lang=de.

Ökostromgesetz-Novelle (2006): „Beschluss des Nationalrates, Bundesgesetz, mit dem das Ökostromgesetz, das Elektrizitätswirtschafts- und -organisationsgesetzt und das Energie-Regulierungsbehördengesetz geändert werden (Ökostromgesetz-Novelle 2006)“, 655 der Beilagen XXII. GP, 2006

Ökostromgesetz-Novelle 2006: BGBI I Nr 105/2006.

Part, P. et al. (2006): Austria: Pension Projections 2004 - 2005. BMF Working Paper 5/2006.

Romp, W. and de Haan, J. (2005): Public capital and economic growth: a critical survey, EIB papers vol. 10 (1), pp. 40-42.

Scherer F.M. and D. Ross (1990): Industrial Market Structure and Economic Performance, Houghton Mifflin Co., Boston.

Schibany et al. (2004): Imput Additionality Effects of R\&D subsidies in Austria, Institute of Technology and Regional Policy, Vienna, in: http://www.tip.ac.at/publications/schibany0304 RD\%20Financing.pdf.

Science \& Information Technology (2006): vol. 2006, no. 16, pp. $1-315$.

Soete, L. and Weehuizen, R. (2003): The economics of e-Government. A bird's eye view, International Journal of Communications Law and Policy (IJCLP), Issue 8, Winter 2004, http://www.ijclp.org/8 2004/index.html. 
Statistik Austria (2006): Österreichische Forschungsquote 2006 voraussichtlich 2,43\% des BIP..., in: press release 8 565-74/06 from 20.04.2006.

STATISTIK AUSTRIA (2006): press release on research an experimental development, in: http://www.statistik.at/englisch/results/vgr/fue txt1.shtml.

Statistik Austria, http://www.statistik.at/fachbereich 06/txt.shtml and http://www.statistik.at/fachbereich 02/vgr txt.shtml.

Steiner M., Wagner E., Pessl G. (2006): Evaluation der Kurse zum Nachholen des Hauptschulabschlusses [Evaluation of the courses to make up for die compulsory school leaving certificate], Study commissioned by the Federal Ministry of Education, Science and Culture, Vienna.

Stephan, Paula E. (1996): "The Economics of Science", Journal of Economic Literature, Vol. XXXIV, September, 1199-1235.

Stigler G.J. (1964): A Theory of Oligopoly, Journal of Political Economy, Vol. 72(1), pp. 44-61.

Systemnutzungstarife-Verordnung (SNT-VO 2006).

The Giovannini Group (2003): Second Report on EU Clearing and Settlement Arrangements, Brussels, p. 39.

Umweltbundesamt (2006): „Kyoto-Fortschrittsbericht Österreich 1990-2004“, Wien, in: www.umweltbundesamt.at.

Van Reenan, J., (2001): No more skivvy schemes? Active labour market policies and the New Deal for the Youth Unemployed in context, Mimeo, University College London.

Vernon, R. (1996): "International Investment and International Trade in the Product Cycle", Quarterly Journal of Economics, 80 (2), 1966, pp. 190-210.

Winter-Ebmer R. (2001): Evaluation an Innovative Redundancy-Retraining Project: The Austrian Steel Foundation, IZA DP No. 277, Institute for the Study of Labour, Bonn.

WKO (2006): Unternehmensneugründungen in Österreich, in: http://wko.at/statistik/jahrbuch/ng-bundeslaender.pdf 

Authors: Berger J., Felderer B., Fortin I., Gstrein M., Graf N., Hofer H., Kuschej H., Leitner A., Mateeva L., Paterson I., Schuh U., Schwarzbauer W., Skriner E., Steiner M., Strohner L., Weyerstraß K., Wroblewski A.

Title: $\quad$ Evaluation of the Austrian National Reform Programme 2005-2008, Effects on Growth and Employment

Projektbericht/Research Report

(C) 2006 Institute for Advanced Studies (IHS),

Stumpergasse 56, A-1060 Vienna • 용 +43 1 59991-0 • Fax +43 1 59991-555 • http://www.ihs.ac.at 